\title{
EDUCAÇÃO E ARTES: POSSIBILIDADES, EXPERIÊNCIAS E CONTEMPORANEIDADES
}

Organizadores: Ana Cláudia Barin Angélica Neuscharank Fabiano Eloy Atílio Batista
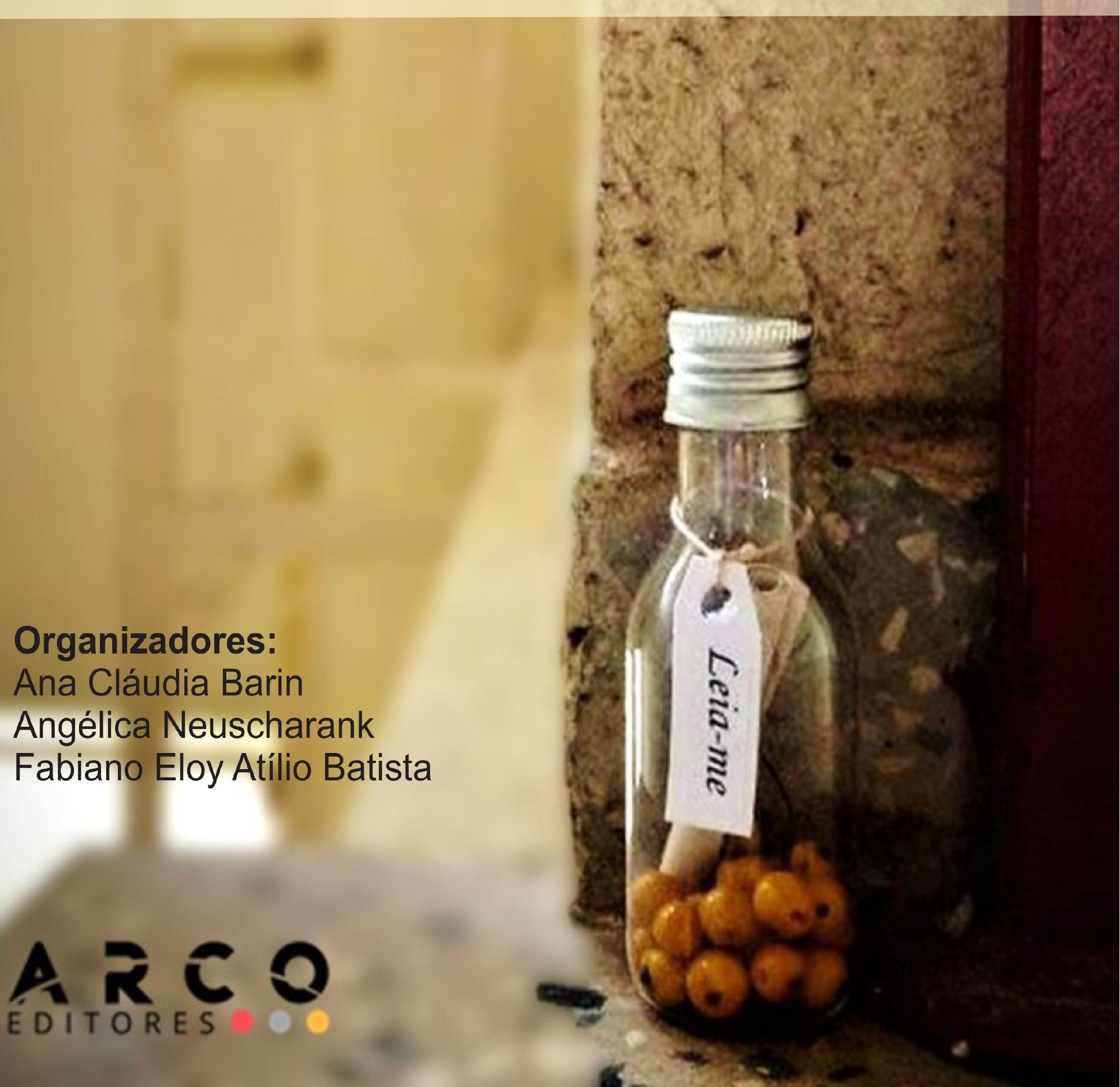


\section{EDUCAÇÃO E ARTES: POSSIBILIDADES, EXPERIÊNCIAS E CONTEMPORANEIDADES}

Organizadores: Ana Cláudia Barin Angélica Neuscharank Fabiano Eloy Atílio Batista
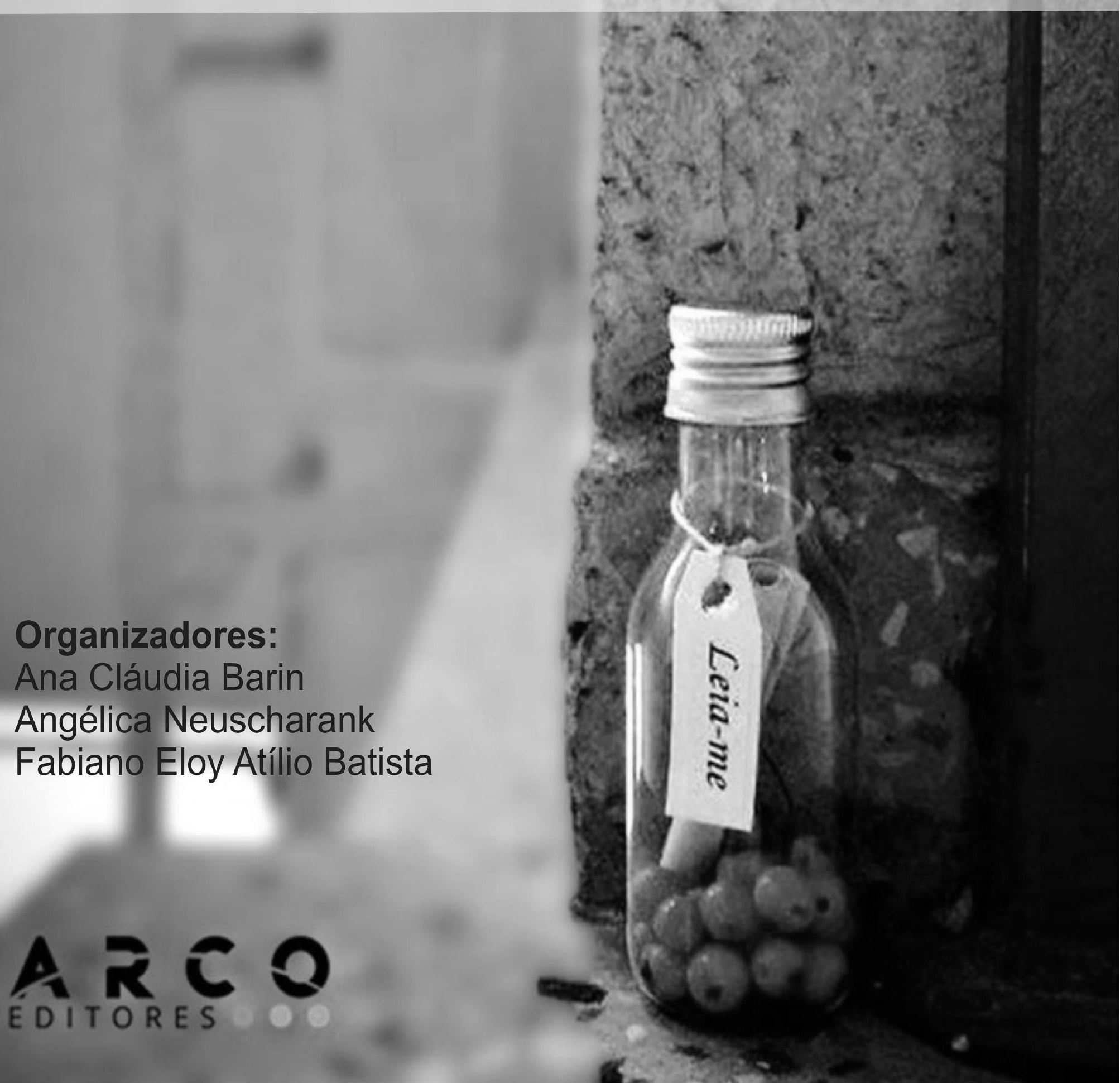


\section{Conselho Editorial}

Prof. Dr. Adilson Tadeu Basquerot e Silva

Profa. Msc. Jesica Wendy Beltrán

Profa. Dra Fabiane dos Santos Ramos

Dr. João Riél Manuel Nunes Vieira de Oliveira Brito

Profa. Dra. Alessandra Regina Müller Germani

Prof. Dr. Everton Bandeira Martins

Prof. Dr. Erick Kader Callegaro Corrêa

Prof. Dr. Pedro Henrique Witchs

Prof. Dr.Thiago Ribeiro Rafagnin

Prof. Dr. Mateus Henrique Köhler

Profa. Dra. Liziany Müller Medeiros

Prof. Dr. Camilo Darsie de Souza

Prof. Dr. Dioni Paulo Pastorio

Prof. Dr. Leonardo Bigolin Jantsch

Prof. Dr. Leandro Antônio dos Santos

Dr. Rafael Nogueira Furtado

Profa. Dra. Angelita Zimmermann

Profa. Dra. Francielle Benini Agne Tybusch

Dados Internacionais de Catalogação na Publicação (CIP)

(Câmara Brasileira do Livro, SP, Brasil)

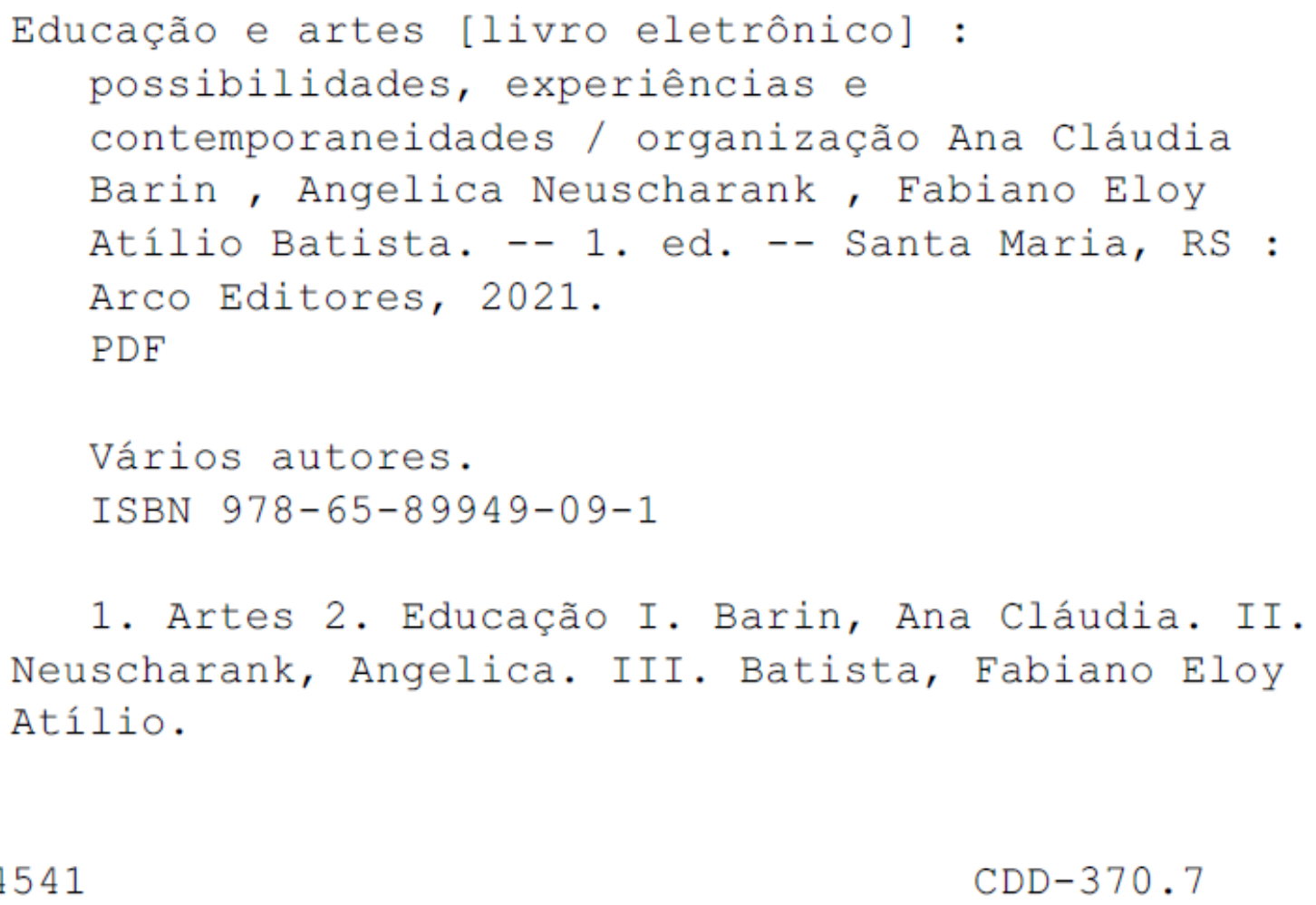

1. Artes 2. Educação I. Barin, Ana Cláudia. II. Neuscharank, Angelica. III. Batista, Fabiano Eloy Atílio. $\mathrm{CDD}-370.7$

Índices para catálogo sistemático:

1. Educação : Arte : Experiência : Educação 370.7

Aline Graziele Benitez - Bibliotecária - CRB-1/3129 
"Eu não sei quando isso tudo vai passar, mas espero fortemente que outras palavras, calibradas por outros desejos de existência possam vir à tona. E que o cuidado de si e do outro se amplie num convívio cotidiano, partilhado entre sujeitos dessemelhantes. Ailton Krenak em seu livro Ideias para Adiar o Fim do Mundo, diz uma coisa que me entusiasma muito, e nela acredito: 'Definitivamente não somos iguais, e é maravilhoso saber que cada um de nós que está aqui é diferente do outro, como constelações"'.

Rosane Preciosa 


\section{APRESENTAÇÃO}

Caros leitores e leitoras,

\section{A coletânea EDUCAÇÃO E ARTES: POSSIBILIDADES, EXPERIÊNCIAS} E CONTEMPORANEIDADES, acolheu estudos que possibilitaram alargar as discussões sobre os campos da educação e das artes, sobretudo para que pudéssemos pensar as diferentes perspectivas e modos de atuação que as artes têm acionado no contexto contemporâneo. Nesse sentido, a elaboração da presente coletânea intenta esboçar algumas linhas do que tem sido experienciado, produzido e articulado em espaços educativos formais e não-formais e do que nos chega como possibilidades de existência em um mundo pandêmico.

O primeiro capítulo de autoria de Vivien Kelling Cardonetti, Francieli Regina Garlet e Marilda Oliveira de Oliveira intitulado DOS ENCONTROS COM IMAGENS FÍLMICAS E DAS APROPRI[AÇÕES QUE MOVIMENTAM A DOCÊNCIA A HABITAR ESPAÇOS 'SEM DONO', apresenta uma investigação em torno do conceito de apropriação, construindo relações com imagens fílmicas, escritas e docências. Apresenta experimentações com encontros e escritas propostas durante uma disciplina do curso de Licenciatura em Artes Visuais, Cinema e Educação (Prática Educacional VIII), na Universidade Federal de Santa Maria (UFSM), localizada ao Sul do país.

No segundo capítulo, o artigo CONVITES DE ABERTURA AO OUTRO: COMPOSIÇÕES E EXPERIMENTAÇÕES COM CRIANÇAS RURAIS de Samara Facco e Alice Copetti Dalmaso nos convida a pensar sobre a atmosfera pandêmica e o que ela evocou para compor com a docência, a partir e com as existências das crianças. Em uma escrita ensaísta e experimental, as autoras apresentam as possibilidades e contaminações do ensino remoto em uma turma multisseriada da Pré-escola, localizada no interior do município de Nova Palma, Rio Grande do Sul (RS), e nos movimentam a pensar sobre as nossas certezas e modos de fazer docentes, que por sua vez, foram postos à prova, em risco, revistos... 


\section{O artigo intitulado PANDEMIA E EDUCAÇÃO: DESAFIOS NA FORMAÇÃO}

INICIAL EM ARTES VISUAIS, de autoria de Eduarda Teixeira Streck, Rute Abadie Fernandes e Stefani Souza de Jesus, procura discutir sobre uma docência que se constrói em meio ao caos (ocasionado pela pandemia do COVID-19), a partir do compartilhamento de experiências vivenciadas pelas autoras, estudantes do $7^{\circ}$ semestre da disciplina de Estágio Supervisionado, do Curso de Licenciatura em Artes Visuais, da Universidade Federal de Santa Maria (UFSM).

\section{No artigo A DANÇA E SUA RELAÇÃO COM A CULTURA E A EDUCA-} ÇÃo, que compõe nosso quarto capítulo, de autoria de Alexandra Aparecida dos Santos Noronha e Fernando Luiz Zanetti, os autores buscam pensar e escrever sobre as relações entre dança, cultura e educação. Assim, problematizam e articulam ideias acerca das pedagogias culturais sobre o ensino de dança no contexto escolar, e sobre a importância da dança na educação. Além disso, os autores buscam trazer uma averiguação de como a pandemia do novo Coronavírus afetou a educação e, principalmente, o ensino de dança nas escolas.

Compondo o quinto capítulo temos o texto intitulado DANÇA EDUCATIVA MODERNA NA ESCOLA, de autoria de Daniela Grieco Nascimento e Silva, Marcia Gonzalez Feijó e Tatiana Wonsik Recompenza Joseph, o qual busca tensionar questões sobre as possibilidades da dança educativa moderna na educação, sendo compreendida no desenrolar do texto como Arte e Educação no espaço escolar na medida em que pretende ressignificar concepções de um corpo/sujeito sob o viés artístico-educativo.

Prosseguindo com as discussões sobre educação e dança, o sexto capítulo de autoria de Daniela Grieco Nascimento e Silva, Marcia Gonzalez Feijó e Tatiana Wonsik Recompenza Joseph denominado DANÇANDO FAZERES E SABERES EM ARTE E EDUCAÇÃO, busca apresentar e tecer as ações artísticas e educativas desenvolvidas há 22 anos pela ONG Royale Escola de Dança e Integração Social, na cidade de Santa Maria - RS. Assim, as autoras apresentam a proposta artístico-educativa, desenvolvidas pela ONG, que tem o ballet como núcleo central, buscando embasar as escritas nos princípios teóricos do educador brasileiro Paulo Freire, que sempre defendeu o foco do ensino como uma aprendizagem 
centrada no educando e no aprender, e não no educador e no ensinar.

O sétimo capítulo denominado ENSINO COLETIVO DE INSTRUMENTO, de autoria de Alex de Paula, aborda, de forma inaugural, sobre os mecanismos utilizados para o ensino coletivo de instrumento, tendo como foco uma comunidade no interior de Minas Gerais (MG). Assim, ao longo do texto, podemos observar a metodologia usada em uma classe de ensino de instrumento na cidade de Governador Valadares/MG onde foi realizada essa pesquisa, buscando identificar formas e metodologias eficazes para o ensino coletivo de instrumentos.

De autoria de Alexandre Santiago da Costa, o oitavo capítulo intitulado ARTE NA EDUCAÇÃO INFANTIL, busca discutir os impactos e transformações de uma formação ludoestética em contexto na prática pedagógica do educador infantil para o ensino de artes visuais. Nesse sentido, o texto discute a formação a partir de princípios éticos, políticos e estéticos que estejam atrelados às experiências do brincar e das interações sociais.

O nono capítulo nomeado como CULTURA POPULAR E ENSINO DE ARTE - PROCESSOS IDENTITÁRIOS, de autoria de Christiane de Faria Pereira Arcuri, traz como contribuição para o campo das artes as discussões e pesquisas acerca da difusão do que se entende como cultura popular no ensino de Arte, da educação básica à pós-graduação, atravessando a formação acadêmica de licenciados, desde suas conceituações transitórias à sua aplicabilidade pedagógica.

O artigo intitulado O ENSINO DA COR ATRAVÉS DA TEORIA DE PAUL KLEE, de autoria de Silvana dos Passos Silva e Ana Luiza Ruschel Nunes, compõe nosso décimo e penúltimo capítulo, e apresenta o processo e análise dos resultados de uma prática educativa em Artes Visuais, tendo como investigação a questão da aprendizagem sobre o conhecimento da cor em sua complexidade artística, educacional e cultural, trazendo, por finalidade, algumas questões de reflexão e possíveis avanços investigativos em relação à temática.

Concluímos esta coletânea com o artigo ENCONTROS COM O FILME A 'ÁRVORE DA VIDA': DISPARADORES PARA PENSAR A EXPERIÊNCIA EDUCATIVA, de autoria de Vivien Kelling Cardonetti e Marilda Oliveira de Oliveira, 
que apresenta um texto a partir de fragmentos dos diários pessoais das autoras a fim de pensar experiências realizadas com estudantes de Licenciatura em Artes Visuais da Universidade Federal de Santa Maria (UFSM). A escrita instigante produz relação com o filme "Árvore da Vida" e estabelece relações com a formação docente dentro do campo da arte e educação.

Esperamos que todos e todas tenham uma excelente e agradável leitura!

Ana Cláudia Barin Angelica Neuscharank Fabiano Eloy Atílio Batista Organizadores 


\section{SUMÁRIO}

\section{CAPÍTULO 1}

DOS ENCONTROS COM IMAGENS FÍLMICAS E DAS APROPRI[AÇÕES] QUE MOVIMENTAM A DOCÊNCIA A HABITAR ESPAÇOS 'SEM DONO'

Vivien Kelling Cardonetti

Francieli Regina Garlet

Marilda Oliveira de Oliveira

DOI: 10.48209/978-65-89949-09-2

\section{CAPÍTULO 2}

CONVITES DE ABERTURA AO OUTRO: COMPOSIÇÕES E EXPERIMENTAÇÕES COM CRIANÇAS RURAIS

Samara Facco

Alice Copetti Dalmaso

DOI: 10.48209/978-65-89949-09-3

\section{CAPÍTULO 3}

PANDEMIA E EDUCAÇÃO: DESAFIOS NA FORMAÇÃO INICIAL EM ARTES VISUAIS.

Eduarda Teixeira Streck

Rute Abadie Fernandes

Stefani Souza de Jesus

DOI: 10.48209/978-65-89949-09-4

\section{CAPÍTULO 4}

A DANÇA E SUA RELAÇÃO COM A CULTURA E A EDUCAÇÃO. .54

Alexandra Aparecida dos Santos Noronha

Fernando Luiz Zanetti

DOI: 10.48209/978-65-89949-09-5 


\section{CAPÍTULO 5}

DANÇA EDUCATIVA MODERNA NA ESCOLA: ALGUMAS REFLEXÕES .67

Daniela Grieco Nascimento e Silva

Marcia Gonzalez Feijó

Tatiana Wonsik Recompenza Joseph

DOI: 10.48209/978-65-89949-09-6

\section{CAPÍTULO 6}

DANÇANDO FAZERES E SABERES EM ARTE E EDUCAÇÃO: UM RELATO SOBRE A EXPERIÊNCIA DA ONG ROYALE ESCOLA DE DANÇA E INTEGRAÇÃO SOCIAL .80

Daniela Grieco Nascimento e Silva

Marcia Gonzalez Feijó

Tatiana Wonsik Recompenza Joseph

DOI: 10.48209/978-65-89949-09-7

\section{CAPÍTULO 7}

ENSINO COLETIVO DE INSTRUMENTO: A METODOLOGIA USADA EM UMA COMUNIDADE DE GOVERNADOR VALADARES/MG...................98

Alex de Paula

DOI: 10.48209/978-65-89949-09-8

\section{CAPÍTULO 8}

ARTE NA EDUCAÇÃO INFANTIL: IMPACTOS E TRANSFORMAÇÕES NA FORMAÇÃO DOS DOCENTES DA PRIMEIRA INFÂNCIA....................106

Alexandre Santiago da Costa

DOI: 10.48209/978-65-89949-09-9

\section{CAPÍTULO 9}

CULTURA POPULAR E ENSINO DE ARTE - PROCESSOS IDENTITÁRIOS 


\section{CAPÍTULO 10}

FUNDAMENTOS TEÓRICOS DA COR E A PRÁXIS ARTÍSTICA NO ENSINO TÉCNICO INTEGRADO EM QUÍMICA INDUSTRIAL....................................138

Silvana dos Passos Silva

Ana Luiza Ruschel Nunes

DOI: 10.48209/978-65-89949-11-1

\section{CAPÍtULO 11}

ENCONTROS COM O FILME A 'ÁRVORE DA VIDA': DISPARADORES PARA PENSAR A EXPERIÊNCIA EDUCATIVA.

Vivien Kelling Cardonetti

Marilda Oliveira de Oliveira

DOI: 10.48209/978-65-89949-12-1

SOBRE OS ORGANIZADORES 


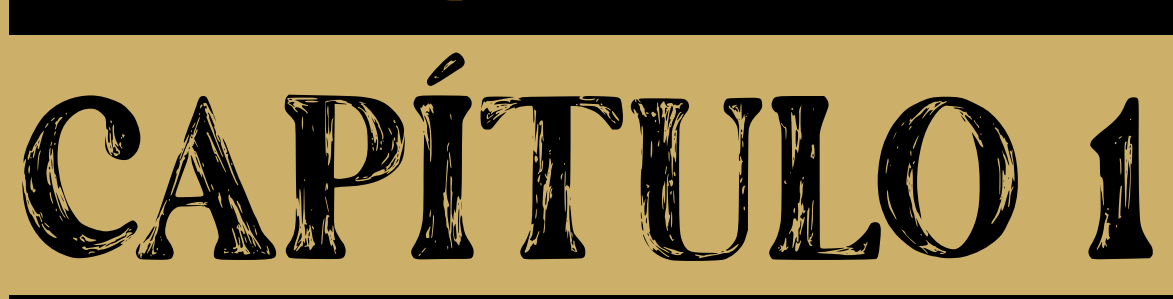

\title{
DOS ENCONTROS COM IMAGENS FÍLMICAS E DAS APROPRI[AÇÕES] QUE MOVIMENTAM A DOCÊNCIA A HABITAR ESPAÇOS 'SEM DONO'...'
}

\author{
Vivien Kelling Cardonetti ${ }^{2}$ \\ Francieli Regina Garlet ${ }^{3}$ \\ Marilda Oliveira de Oliveira ${ }^{4}$
}

\footnotetext{
1 Uma versão ampliada deste artigo foi publicada no início de 2021 na revista Reflexão e Ação (n. 1, v. 29) do Programa de Pós-Graduação em Educação da Universidade de Santa Cruz do Sul (UNISC).

2 Professora externa do Curso de Graduação a Distância de Educação Especial na Universidade Federal de Santa Maria (UFSM). Possui Pós-Doutorado (2019) e Doutorado (2014) em Educação pelo Programa de Pós-Graduação em Educação - PPGE, na Linha de Pesquisa Educação e Artes, na UFSM. E-mail: vicardonetti@gmail.com

3 Pós-doutoranda do Programa de Pós-Graduação em Educação da Universidade Federal de Santa Maria (PPGE/UFSM). Doutora e Mestre em Educação pela mesma instituição e Programa de Pós-Graduação. Graduada em Artes Visuais - Licenciatura e Bacharelado (UFSM). Membro do Grupo de Estudos e Pesquisas em Arte, Educação e Cultura (GEPAEC).

E-mail: francieligarlet@yahoo.com.br

4 Professora Titular do Departamento de Metodologia do Ensino, Centro de Educação da Universidade Federal de Santa Maria. Doutora em História da Arte pela Universidad de Barcelona, Espanha. Coordenadora do Grupo de Estudos e Pesquisas em Arte, Educação e Cultura (GEPAEC).

E-mail: marildaoliveira27@gmail.com
} 
O presente capítulo é composto de encontros que nascem em meio a docências atravessadas por experiências educativas em um Curso de Licenciatura em Artes Visuais, mas também em meio a uma escrita produzida por seis mãos e por muitos outros corpos/pensamentos. Essa escrita toma como movimento o conceito de apropriação (CHIARELLI, 2002; OLIVEIRA, DAHMER, 2017; KNAAK, 2005), relacionando-o com imagens fílmicas, escritas e docências costuradas por um pensamento que não se sabe antes do encontro, pois é da ordem do acontecimento.

Buscamos, em suma, movimentar o conceito de apropriação junto às experimentações com escritas propostas durante a disciplina Cinema e Educação (Prática Educacional VIII), ministrada pela primeira e terceira autora deste texto, no ano de 2016, na Universidade Federal de Santa Maria (UFSM). Nessa disciplina, foram trabalhados oito filmes, com o intuito de acionar [im]possíveis conexões com a educação e a docência. Referimo-nos aos [im]possíveis ao comungarmos com Deleuze (2010) quando menciona que podemos "falar da criação como traçando seu caminho entre impossibilidades" (DELEUZE, 2010, p. 171), ou ainda quando o autor escreve que "um criador é alguém que cria suas próprias impossibilidades, e ao mesmo tempo cria um possível" (Ibidem, p. 171). A ideia, portanto, era acionar por tensionamentos e [im]possibilidades uma docência pensada desde outros lugares (com imagens fílmicas que não tratavam diretamente de docência, que não ilustravam uma docência) - um possível a ser forjado em meio a aparentes impossibilidades de conexão.

Assim, neste capítulo, focalizamos e exploramos os fragmentos de uma acadêmica que passou a produzir uma interlocução com a docência e a educação, ao se apropriar de três produções cinematográficas trabalhadas no decorrer do semestre, quais sejam: Onde fica a casa do meu amigo? (direção de Abbas Kiarostami, 1987), Tempo de embebedar cavalos (direção de Bahman Ghobadi, 2001) e O balão branco (direção de Jafar Panahi, 1995). Portanto, interessa-nos um movimento operatório que é também o de apropriação (enquanto um 'habitar', 'ocupar' e 'friccionar') referente à escrita da referida acadêmica, atentando àquilo que pode ainda disparar em nós, durante movimentos de escrita e de criação de outros [im]possíveis em meio à educação, à docência e a nós mesmas. 
As perguntas-problemas que nos chegam e nos arrastam junto desse processo de apropriação são: como um movimento de apropriação de imagens fílmicas que não propriamente dizem de docência e de educação podem conferir à docência e à educação outras possibilidades de existência? Como manter pulsante aquilo de que nos apropriamos? Como produzir um encontro com a parte 'sem dono', ainda por se fazer da docência e da educação?

Ao mencionar 'sem dono', referimo-nos à parte das coisas ainda em estado de virtualidade. Para Deleuze (2006), todos os objetos possuem metades desiguais atuais e virtuais; o que eles são a cada vez (ou o que temos como dado, pronto sobre eles) e o potencial de vir a ser outras coisas ainda não imaginadas. Supomos que, ao nos apropriarmos de algo, no movimento de criação que essa ação implica, habitaríamos a parte virtual das coisas, isto é, a parte em que podemos acionar outras produções de sentidos, que escapam ou fazem vazar o que já está dado sobre elas. Segundo Corazza (2007),

entre uma linguagem e outra [...] existem pontos de silêncio, vazios de linguagem, vácuos de ângulos classificatórios, pontos de vista não perspectivados, enunciados ainda a serem articulados. [...] Só aqui é possível produzir abalos; provocar mudanças no que somos capazes de ver e de dizer; dar alegres cambalhotas; radicalizar nossas relações com o poder e o saber; partir as linhas; mudar de orientação; desenhar novas paisagens; promover outras fulgurações. Enfim, artistar, inventando novos estilos de vida e, portanto, de práticas (CORAZZA, 2007, p. 122).

Corazza (2007), nessa passagem, convida-nos a olhar para a docência como um espaço de criação que provoca a experimentar o mundo uma e outra vez e, também, a partir do que não está dado sobre ele. O processo de apropriação pode contribuir, dessa maneira, para que venhamos a "nos apropriar daquilo que nos cerca e produzir outros sentidos" (OLIVEIRA; DAHMER, 2017, p. 78). Ao habitar essa zona de vizinhança, passamos de algum modo a engendrar também um movimento de apropriação de nós mesmos, implicando, assim, na abertura de infinitas possibilidades de sermos diferentes do que somos.

\section{APROPRI[AÇÕES]... APROP[RIAR-SE]...}

O que nos resta diante de um mundo em que tudo parece já ter sido dito e visto? Um mundo em que a docência e a educação já parecem ter esgotado suas 
infinitas possibilidades de existir? O que fazer com o que já está aí, com o que já foi produzido a respeito de docência, de educação, de vida? Compor, recompor, apropriarmo-nos. Sujarmos de nós o que já está aí, compondo com eles outros [im]possíveis. Compor com as coisas deste mundo, em movimentos micro, outros mundos dentro do mundo (DELEUZE, 2006). Atentar para o que de singular emerge do nosso encontro com o que já está posto.

O termo apropriação diz respeito aqui a um apropriar-se daquilo que originalmente não nos pertence (KNAAK, 2005) e acrescentar outros focos de luminosidade, intensificando sua potência e colocando em incessante movimento. Um roubo, ao modo deleuziano (DELEUZE; PARNET, 1998), um modo de fazer algo fugir...

Para Chiarelli (2002), o conceito de apropriação está baseado na ideia de que:

Apropriar-se não significa, em princípio, apropriar-se de apenas um ou dois objetos ou imagens da mesma natureza, ou com uma ou várias características comuns. Apropriar-se é matar simbolicamente o objeto ou a imagem, é retirá-los do fluxo da vida - aquele contínuo devir, que vai da concepção/produção até a destruição/morte - colocando-os lado a lado a outros objetos, com os mais diversos intuitos (CHIARELLI, 2002, p. 21).

Chiarelli acrescenta que pensar o conceito de apropriação é "elevar os seus sentidos a partir do seu deslocamento para outros espaços, juntando-o a elementos diversos" (CHIARELLI, 2002, p. 21). Nesse sentido, podemos pensar a produção de um 'entre' enquanto um terreno 'sem dono' que perpassa essas composições e conexões.

À vista disso, mais algumas questões emergem dessas conversações: podemos nos considerar um desses elementos nessa composição? Podemos pensar o que se desloca em nós nesses encontros? O que nos acontece em um processo de apropriação? Em um apropriar-se? Como entramos nessa composição? O que escapa e escorre de nós nessas composições?

Esses questionamentos nos instigam a brincar/experimentar algumas variações da palavra apropriação: 
- Apropri[ações]: colocar em ação/movimento, desde si ${ }^{1}$, o que já está adequado, confortável, considerado próprio.

- Aprop[riar-se]: fazer-se rio, escorrer de si, 'riar-se'.

Antes de tomar o termo apropriação a partir da ideia de um eu já definido que toma algo para si, com vistas a exercer um poder sobre aquilo de que se apropria, interessa-nos uma relação de produção de potências gestadas transversalmente (não verticalmente e tampouco horizontalmente) nesse encontro. Apropriar-se, aqui, diz, talvez, mais respeito a produzir moradas e sentidos provisórios em terrenos ainda sem donos e não definidos, para que outras fagulhas ou correntes de ar possam arrastar as formas que já estão dadas... Diz de (morar)-se na parte sem dono, indefinida e selvagem das coisas que arrasta todas as instâncias envolvidas, que modificam aquilo que é apropriado e também aquele que se apropria, que faz nascer em ambos o desejo de partir, de descolar-se de onde se está para segu[ir]... dev[ir]... ir...

Ao explorar a experiência vivenciada na disciplina com as imagens fílmicas, junto a esse conceito de apropriação, passamos a ser impelidas a pensar que tais imagens se deixaram arrastar pela visão dos acontecimentos e pelas exigências em cena, impulsionando o atravessamento de variáveis fluxos de forças. Por estarem imbricadas nas contingências de cada encontro, passaram a ser provisórias, mutantes e deslocáveis.

É no sentido de colocar em movimento tais aspectos pontuados que utilizamos o conceito de apropriação nesta escrita. A apropriação é vista na investigação como algo que nos permite visitar o instituído da imagem fílmica ou de qualquer outro elemento, fazendo um movimento de atualização ${ }^{2}$ e conferindo fissuras na linearidade temporal e em certas verdades discursivas. Isso instiga a pensar nas inúmeras possibilidades que podem ser inventadas com a aproximação, a aliança, o tensionamento e o embaralhamento de elementos heterogêneos, como imagens fílmicas, educação e docências em formação, pois propicia a intervenção no que está posto, a exploração de novos ângulos e a cria-

1 O si como "extremidade prolongada do Caos, das forças [...]" o que difere da noção de 'eu' enquanto "prisioneiro da gramática, das suas funções". Si como um "estrangeiro que cada um carrega consigo" (PELBART, 2016, p. 68).

2 A atualização diz respeito a um movimento de variação, de produção de uma diferença que se dá a partir de um recorte de uma virtualidade (DELEUZE, 1999). 
ção infinita de outras séries e arranjos.

Levando em consideração essas colocações, outras questões passaram a nos inquietar: Que maquinarias são postas para funcionar no emaranhado entre docência, educação e imagem fílmica? Que outras potências de existir são acionadas nelas nesse processo? O que acontece quando uma aula que quer pensar o cinema e a educação escapa a uma abordagem pedagógica da imagem fílmica?

\section{APROPRI[AÇÕES] DE IMAGENS FÍLMICAS}

A presença da imagem fílmica em meio às experiências educativas tem atravessado alguns campos de estudo e de experimentações nos últimos tempos. Em meio a esses estudos tem nos interessado algumas vias tomadas por autores que se aproximam e são movimentados pelas filosofias da diferença, como César Donizetti Pereira Leite (2014), Fabiana de Amorim Marcello (2008), Jorge Vasconcellos (2006), Antônio Carlos Rodrigues de Amorin (2018) e Marilda Oliveira de Oliveira (2014). Dentre as inúmeras possibilidades existentes, o cinema pode ser visto como um campo de experimentações do pensar, uma 'máquina de pensar' (DELEUZE, 1990), pois "mais importante do que o pensamento é aquilo que faz pensar" (DELEUZE, 2010, p. 29).

É esta perspectiva que nos interessa explorar, pois o cinema, por ser uma matéria pensante e inteligível, pode impulsionar a criação de pensamentos, propiciando atuar no mundo apresentado e no cotidiano alheio. Ao experimentar outras vidas passamos a vivenciar mundos que pareciam inviáveis. Essa experiência propicia que ampliemos as perspectivas do nosso cenário existencial, instigando-nos a pensar de forma diferente e a agir de outro modo.

Deleuze (2010) afirma que "o cinema é produtor de realidade" (DELEUZE, 2010, p. 80). Essa colocação nos faz pensar que a experiência ao assistir a um filme é real, porque as cenas e as sensações são mostradas de forma que venhamos a sentir, vivenciar e nos produzir a cada momento. Nesse viés, as imagens fílmicas ou os signos fílmicos podem ser encarados como disparadores de provocações que impulsionam a possibilidade de olhar de outro modo para determinados hábitos do pensamento ainda arraigados e solidificados em nós. 
Dessa forma, temos investigado possibilidades que se distanciam do uso pedagógico e instrumental dos filmes ${ }^{3}$, na qual a ênfase se coloca muitas vezes em uma moral a ser decifrada e apreendida ou no reforço de ilustrar algum conteúdo que se deseja trabalhar. Ela aposta em outra via, pois a intenção é pensar nos afetos ${ }^{4}$ e nas possibilidades de relações que podem ser estabelecidas a partir dos signos emitidos pelo filme e pela atmosfera acontecimental do encontro.

À vista disso, a intenção foi ensaiar algumas experimentações escritas e visuais com as imagens fílmicas trabalhadas na disciplina Prática Educacional VIII, buscando não um pensar com ideias acabadas e definidas previamente, "mas ideias que possam compor outras ideias, outras cenas que possam ser apresentadas, bricoladas, montadas, desmontadas, plurais" (LEITE; CHRISTOFOLETTI, 2015, p. 44).

Em vez de serem interpretadas, as imagens fílmicas passaram a nos oferecer singulares relações com a docência e com a educação, pois ressoaram em múltiplas direções e sentidos, convidando-nos a engendrar diferentes experimentações. Ao tirarmos proveito de sua faculdade plural, elas foram impelidas a outras imagens, diversamente do sentido representativo, em que as imagens voltam para si mesmas. Essa faculdade múltipla contribuiu para sua profusão e dispersão, o que nos faz pensar que "uma imagem nunca está só. O que conta é a relação entre as imagens" (DELEUZE, 2010, p. 71-72).

Dessa forma, afirmamos que é no interstício, no 'entre' das imagens fílmicas que muitas coisas podem ser cruzadas e construídas. É neste espaço aberto que alianças são concebidas e que inesperadas construções de sentidos são inventadas, fazendo-nos compreender que a maneira de se relacionar com a imagem fílmica não depende exclusivamente do olhar do observador, tampouco somente do que é visualizado, e sim daquilo que foi possível de ser produzido nesse tensionamento, na apropriação desse espaço 'sem dono', que se dá no entre das conexões.

$3 \quad$ Algumas dessas experimentações podem ser acessadas nas seguintes publicações: (CARDONETTI, 2014), (CARDONETTI; GARLET; OLIVEIRA, 2014), (CARDONETTI; OLIVEIRA, 2019), (OLIVEIRA, 2014).

4 Entendemos afeto a partir das contribuições de Spinoza (2016) e Deleuze (1978, on-line), como variações nas potências de existir por meio dos encontros que temos e como "um modo de pensamento não representativo", como algo que é acionado, disparando devires. 
Para além das imagens mostradas numa tela, está a problematização, a apropriação, o tensionamento com outros elementos. É nesse 'entre', ora silencioso, potente, vazio e povoado, que o ato da criação se faz presente, a qual é produzida durante a experimentação, passando a ser "um processo de autocriação, de criação de si; ou seja, um diferenciar, diferenciando-se" (CORAZZA, 2013, p. 98). No caso da disciplina, um inventar-se docente junto das imagens fílmicas e das produções visuais e escritas que emergiram desse encontro insuspeito entre cinema, docência e educação.

\section{A METOdOLOGIA QUE NOS ACOLHEU...}

Cada pesquisa possui uma metodologia que se configura como um envolvimento com aquilo que vai produzindo sentido. A metodologia vai abraçando o pesquisador, acolhendo-o e o capturando; vai se construindo durante o percurso, tomando parte desse processo a partir de uma experiência que se desloca. Nesse sentido, com a intenção de atender aos nossos anseios, optamos pela perspectiva cartográfica de investigação, que abriga uma aventura transversal de movimentação.

Apresentada por Gilles Deleuze e Félix Guattari (1995a) na introdução de seu livro Mil Platôs - Capitalismo e esquizofrenia, a cartografia é uma abordagem de investigação que aposta na experimentação e não na aplicação de procedimentos metodológicos. Nessa perspectiva, a cartografia passa a ser encarada como "um desenho que acompanha e se faz ao mesmo tempo em que os movimentos de transformação da paisagem" (ROLNIK, 2006, p. 23).

Contudo, vale salientar que esse método não é um caminhar sem direção ou sem sentido; trata-se de um trilhar que vai construindo o trajeto e é construído por ele, a partir de afetos que se produzem e vão produzindo o percurso. É por isso que a investigação do processo de produção é tão cara para a cartografia, porque é no percurso que os dados da pesquisa são produzidos. Nesse viés, não há nada a ser descoberto, desvelado ou reproduzido, mas um terreno em constante movimento a ser experimentado e cartografado.

O campo coletivo de forças da investigação foi redesenhado constantemente no decorrer da disciplina Cinema e Educação, com cruzamentos transversais de 
imagens fílmicas que não propriamente diziam de docência e de educação, mas que possibilitaram pensar outras vias relacionadas a essas duas temáticas. Tais movimentos que seguem nessa escrita buscam apostar na dinâmica da transversalidade, redesenhando paisagens e instaurando outros [im]possíveis.

O conceito de 'transversalidade' foi proposto por Guattari em 1964, servindo-lhe, inicialmente, para pensar "o movimento de abertura comunicacional, de desestabilização dos eixos dominantes de organização da comunicação nas instituições" (PASSOS; BARROS, 2015, p. 155). Como coloca Passos e Eirado, o movimento transversal viabiliza "uma experiência de comunicação que faz variar os pontos de vista, mais do que aboli-los" (PASSOS; EIRADO, 2015, p. 116117), circunscrevê-los ou cerceá-los. Por isso é que a transversalidade faz uso da conjunção 'e', afinal possibilita a exploração de novas conexões e faculta outras tessituras, ou seja, potencializa a vinda do que não se pode prever, abrindo-se a situações inimagináveis e àquilo que não é rotineiro.

A "transversalidade constitui, pois, a forma de fluxo e de encontros entre as singularidades em um rizoma. Sem hierarquia, sem imposição, sem dominação, sem unidade" (GALLO, 2014, p. 195). Ou seja, a transversalidade seria o modo de mobilidade por entre os liames de um rizoma ${ }^{5}$, de modo que os saberes, a partir de suas singularidades, passam a se conectar e se misturar conforme seus interesses e necessidades.

Nessa direção, o investimento nas linhas transversais, traçadas durante as experiências educativas com as imagens fílmicas e os movimentos de escrita, tiveram o intuito de desestabilizar os eixos cartesianos - vertical/horizontal (GUATTARI, 2004), nos quais as formas se apresentam previamente categorizadas e aguardadas, visto que o eixo vertical tem como premissa a hierarquização da comunicação dos diferentes e o eixo horizontal tem a homogeneização da comunicação na corporação dos iguais (PASSOS; EIRADO, 2015).

5 Conceito criado por Deleuze e Guattari e apresentado em Mil Platôs - Capitalismo e esquizofrenia, v.1, como um mapa aberto, no qual "qualquer ponto de um rizoma pode ser conectado a qualquer outro e deve sê-lo. É muito diferente da árvore ou da raiz que fixam um ponto, uma ordem" (DELEUZE; GUATTARI, 1995a, p. 15), em que a estrutura, a sequência e a evolução estão presentes. No rizoma, não existe um centro consolidado a que todos os elementos devem se reportar; busca-se justamente o descentramento dos envolvidos. 
A intenção, com essa metodologia, foi apostar nesse tracejar transversal, que diz respeito às apropriações de diferentes imagens fílmicas, às práticas de escrita em sua força de invenção de outros sentidos, testemunhando o protagonismo em criar possibilidades de docência e de educação que nunca se fecham, mas seguem abertas a outros [im]possíveis de existência.

\section{FAGULHAS DE ESCRITAS E IMAGENS FÍLMICAS...}

Nos encontros semanais da disciplina Cinema e Educação (Prática Educacional VIII) nos interessavam os movimentos acionados pela apropriação de espaços 'entre' imagens fílmicas, docências, educação e dos sentidos (moradas provisórias) que iam sendo produzidos e cartografados junto às escritas e às visualidades. Fagulhas de escrita se descolam do espaço dessa experiência e, em outra temporalidade, seguem a disparar outros escoamentos, produzindo outros 'entres'. Desse modo, parece ser oportuno nos ocupar dos movimentos acionados pelo encontro com escritas e imagens gestadas por uma das acadêmicas naquele momento da disciplina. O importante era nos apropriar dessa terra sem dono (por se fazer), que esse outro encontro produz entre nós - duas professoras da referida disciplina ( $1^{\mathrm{a}}$ e $3^{\mathrm{a}}$ autoras) e uma estrangeira à disciplina ( $2^{\mathrm{a}}$ autora) que se colocam a experimentar, desde outro tempo e lugar, as fagulhas potentes dessa experiência.

Sobrepomos, nesse sentido, camadas temporais e experienciais, de modo a fabricar 'entre' elas outras apropri[ações] e aprop[riarmo-nos] nesse processo. Apropri[ação] e aprop[riar-se] diz respeito, assim, a fazer uma morada provisória na parte das coisas que se encontra ainda sem dono. Alojar-se na parte indefinida das palavras, das imagens, da docência, da educação e ficar então à espreita de suas faíscas de potência; alojar-se no intervalo da relação...

Isso vem ao encontro da escrita da acadêmica Ana Paula Greine, quando menciona a respeito de sua experiência com três das imagens fílmicas trabalhadas na disciplina:

Não é o objeto. Não é o sujeito... É a relação!!!!

Tempo de admitir:

Admito que busquei saber sobre o significado daquele balão branco.

Admito que tive a intenção de entender por que era tempo de embebedar 
cavalos.

Admito que inicialmente busquei achar uma casa ${ }^{6}$

Entretanto, junto dessa busca por uma lógica pré-determinada - a qual estamos acostumados - também havia uma escuta às possibilidades inesperadas que acionaram outras fagulhas de [im]possíveis com escritas e imagens.

Qual o lugar da educação? Existe um? Onde fica a casa da educação? Não sei. Ahmad também não sabia onde ficava a casa de seu amigo, muito embora não deixou de buscá-la, de persegui-la, de traçar seus caminhos até ela, de configurar com a diferença da repetição (DELEUZE, 2006) seu inusitado trajeto. Ahmad percorreu em vias de. Em linhas de. Em devires de. Em uma sinuosa estrada rotas de. Não seria prolífero para mim, Ahmed e a educação completar as lacunas, fechar um final, identificar um substantivo, enfim, encontrar uma casa. Não seria oportuno, para mim, descobrir o lar da educação, onde ela dorme e que horas faz suas refeições. Interessa-me por onde ela anda, por quais terrenos foge quando Ihe pedem rendição, qual esfera plurifacetada mostra quando Ihe fazem juras de habitação, por quais conjecturas de desvencilhamento responde quando é pega em armadilha e improviso. Quero saber onde ela dança, onde compõem suas delirantes poesias, quero saber sobre os corpos dos quais se utiliza para diferir-se de si (FOUCAULT, 2004), quero correr atrás da cara que mostra para seus vaidosos enjauladores: audaciosa. Embarquei, com Ahmed, à procura de uma casa. Percebi, com Ahmed, que a casa era o que menos queria encontrar. Eu queria era o fervor e o frescor da procura. Eu ainda os quero.

Procurar uma casa e encontrar-se com um lugar ainda sem dono, produzido no 'frescor da procura'... Há que se produzir/inventar a casa e ao mesmo tempo manter em potência um lugar de ninguém... Dar consistência sem perder o infinito, diriam Deleuze e Guattari (1992). Como inventar microespaços para nascer de forma inesperada, em meio às casas prontas e vigiadas que encontramos em nossos percursos educativos? Como inventar-se docente clandestino/a e aventureiro/a em casas que há muito tempo residimos e nas quais costumamos habitar sempre de um mesmo modo?

"Seres fronteiriços [...] são seres em trânsito para outra coisa" (LARRO$S A, 2006, p .62)$. Larrosa me falava sobre os Curdos, sobre as fronteiras e sobre o Tempo de embebedar cavalos. Gobhadi me falava sobre sobrevivência. Ayub e Madi me falavam sobre resistência. Eu quero te falar - por mim - sobre o ser (sobrevivente) - em - trânsito (resistente) - docente. Que a ideia de ser sobrevivente reporta-me aos movimentos

$6 \quad$ Alguns fragmentos de escritos da acadêmica Ana Paula Greine, na disciplina Cinema e Educação (2016) serão trazidos sempre em itálico nesta seção. 
que fazemos; que os movimentos que fazemos me dizem sobre nos colocarmos em trânsito; que nos colocarmos em trânsito também concerne a produzirmos resistências; que produção de resistências possuem íntimos diálogos com a docência: resistimos, não transformamos. Criamos nossos micros espaços de resistências dentro dos macros espaços. Não quero ser pretensiosa por demais: transformar a todos e idealizar que alcancemos o mesmo resultado e que sejamos os mesmos às mesmas maneiras são possivelmente um boicote ao ser outro, ao ser em trânsito para outra coisa; ao docente outro! Não tenho a intenção de ser-docente-outro buscando o mínimo múltiplo comum, mas o máximo múltiplo diverso. E, para isso, motivei-me com Ayub a ser fronteiriça, a me colocar em trânsito em busca das outras coisas, das outras Anas, das outras professoras que podem ser acionadas em mim, das minhas outras docências possíveis, de minhas outras resistências quando preciso sobreviver e o ambiente é inóspito, o frio é intenso e a viagem é longa.

Resistir... Habitar a superfície da nossa própria pele, essa fronteira porosa onde afetos pedem passagem... Essa fronteira ambulante de um 'si' em constante produção, onde o mundo percussiona ritmos variados a cada vez, onde marcas se produzem, respiros acontecem, camadas se soltam... Como 'salvar a pele' docente do entupimento de poros, como preservá-la enquanto espaço de passagem, superfície acontecimental que se deixa afetar pelos encontros? Como salvá-la das camadas duras de um eu docente demasiadamente formado? Como deixá-la ir com aquilo que a faz escamar a cada vez?

Resistir... rEXISTIR... Deixar-se ir com as camadas que não mais dizem de nós, e que talvez nunca disseram, para afirmar outras possibilidades de si... Permitir-se trocar de pele... Renovar a pele docente, nos atritos cotidianos... Resistir...

Cambaliante e peregrina ia Razieh em potência infante à busca de um peixinho dourado que tinha barbatanas dançantes. $E$ o que significava o balão branco se o peixe era dourado?

Percebi-me procurando um balão banco até o momento em que Razieh perdeu-se em meio aos encantadores de serpentes. Ali me hipnotizei e me perdi também. Esqueci o nome do filme que olhava, esqueci o objeto de procura, esqueci o sujeito que se movia: estava então me relacionando efetivamente com a narrativa filmica, enfeitiçada... Noto a minha demasiada preocupação em abster-me no aqui e no ali, e não no entre. Noto que muito de mim ainda pretende controlar, fixar, prender, encontrar o objeto, definir o sujeito. Deixei encantar-me, enfeitiçar-me e hipnotizar-me somente quando Razieh, na primeira oportunidade de não se domesticar ao seu próprio objetivo, perambulou junto com as serpentes e compôs seu trajeto nômade, sem destinos fixos. Foi a abertura que possibilitou minha peregrinação. Foram os atravessamentos do caminho que me instigaram 
a pensar em rearranjos, em possibilidades, em outras produções. Foram as relações que eu estabeleci que falam de meu percurso. Não é sobre mim ou sobre o percurso. Não é sobre mim ou filme. Não é sobre mim e a prática educacional. Tudo isso é sobre o 'entre'...

Não seria esse [e...]spaço intervalar, a terra sem dono por excelência?

[e...]spaço onde é possível in[ventar] a cada vez uma

$$
\begin{gathered}
\wedge \wedge \wedge \wedge \wedge \\
\wedge \wedge \text { doce...e... e....e...e......ncia }
\end{gathered}
$$

\section{DO QUE FOI POSSÍVEL PRODUZIR JUNTO A MOVIMENTOS DE APROPRI[AÇÕES]...}

A cada experimentação/apropriação com imagens fílmicas, escritas e leituras, oportunidades de ampliação foram sendo engendradas com a docência. Os arranjos produzidos estão e estarão sempre em constante abertura e movimento, pois elementos novos estão sujeitos a atuar, alguns a serem remanejados e outros colocados em suspensão. Com essas forças em cena, permutam-se partículas, além de outras composições serem produzidas, assegurando o movimento dos fluxos e das energias flutuantes.

Essas experimentações cartográficas que a pesquisa buscou degustar junto da disciplina Cinema e Educação (Prática Educacional VIII) e, numa outra temporalidade, com esta escrita, desafiaram-nos a exercitar um movimento do pensamento, quando nos convidaram a explorar a potência da conjugação 'e' junto das possibilidades inventivas que dela emergem. Nossa intenção foi explorar a relação intensiva que a conjunção 'e' propicia, inferindo as zonas de vizinhança e suas relações de intensidade, mas, principalmente, de implicação: "uma expressão tão simples como e... pode representar o papel de tensor através de toda a linguagem" (DELEUZE; GUATTARI, 1995b, p. 44).

Ao propor cruzamentos transversais e alianças junto das apropriações com as imagens fílmicas, novas relações e arranjos passaram a ser propostos em relação à docência e à educação. Esse tensionamento foi propício para que pudéssemos nos aventurar e ensaiar algumas criações com essas experimentações. 
Favoreceu também a aproximação de elementos que até então, talvez, nunca tenham ficado lado a lado, permitindo, assim, que outras relações de forças pudessem se fazer presentes.

Nesse viés, não houve nada a ser descoberto, desvelado ou reproduzido, mas um terreno em constante movimento a ser cartografado, produzido e inventado. $\mathrm{O}$ campo de experimentações junto às imagens fílmicas, às escritas e às docências foi sendo redesenhado constantemente, definindo-se como um mapa sempre inacabado, contingente e que busca ampliar as possibilidades, mesmo quando há uma necessidade de circunscrevê-lo e cerceá-lo.

O desafio colocado pela disciplina Cinema e Educação (Prática Educacional VIII) foi empreender alguns movimentos de apropriação com as imagens fílmicas que não diziam de docência e tecer algumas relações com a docência e a educação. Já neste capítulo, o exercício de apropriação se deu na provocação de experimentar e compor algo 'com' o que havia sido produzido em outra temporalidade com essas materialidades. Portanto, buscamos nesta escrita manter esse movimento, e quiçá prolongá-lo junto do/a leitor/a que se encontrar com este texto.

\section{REFERÊNCIAS}

AMORIM, Antônio Carlos. Rodrigues. Deslocamentos entre currículo e estudos de cinema experimental. Práxis Educativa, UEPG, v. 13, n. 3, p. 1025-1043, 2018. Disponível em: https://www.revistas2.uepg.br/index.php/praxiseducativa/article/ view/12238. Acesso em: 10 set. 2019.

CARDONETTI, Vivien Kelling. Experiências educativas: ressonâncias de intercessões fílmicas. 2014, 156f. Tese (Doutorado em Educação) - Universidade Federal de Santa Maria, Santa Maria, 2014.

CARDONETTI, Vivien Kelling; GARLET, Francieli Regina; OLIVEIRA, Marilda Oliveira de. Ressonâncias de uma intercessão fílmica que impelem a problematizar a experiência educativa. Educativa, Goiânia-GO, v. 17, p. 341-366, 2014.

CARDONETTI, Vivien Kelling; OLIVEIRA, Marilda Oliveira de. Intercessão fílmica: um encontro sempre em vias de acontecer. Pró-posições, Unicamp, Campinas SP, v. 30, p. 1-23, 2019. 
CHIARELLI, Tadeu. Catálogo Apropriações/Coleções. Porto Alegre: Santander Cultural, 2002.

CORAZZA, Sandra Mara. Labirintos da pesquisa, diante dos ferrolhos. In: COSTA, Marisa Vorraber (org.). Caminhos investigativos I: novos olhares na pesquisa em educação. 3. ed. Rio de Janeiro: Lamparina editora, 2007. p. 103-127.

CORAZZA, Sandra Mara. O que se transcria em educação? Porto Alegre: UFRGS; Doisa, 2013.

DELEUZE, Gilles. Sur Spinoza - Cours Vincennes, cours du 24 jan. 1978. Tradução: Francisco Traverso Fuchs. Disponível em: https://www.webdeleuze.com/ textes/194. Acesso em: 4 out. 2019.

DELEUZE, Gilles. Cinema 2 - A imagem-tempo. Tradução: Eloisa de Araújo Ribeiro. São Paulo: Brasiliense, 1990.

DELEUZE, Gilles. Bergsonismo. Tradução: Luiz B. L. Orlandi. São Paulo: Editora 34, 1999.

DELEUZE, Gilles. Diferença e repetição. 2. ed. Tradução: Luiz Orlandi e Roberto Machado. Rio de Janeiro: Graal, 2006.

DELEUZE, Gilles. Conversações. Tradução: Peter Pál Pelbart. 2. ed. São Paulo: Ed. 34, 2010.

DELEUZE, Gilles; GUATTARI, Félix. O que é a filosofia? Tradução: Bento Prado Junior e Alberto Alonso Muñoz. Rio de Janeiro: Ed. 34, 1992.

DELEUZE, Gilles; GUATTARI, Félix. Mil platôs: Capitalismo e esquizofrenia, v. 1. Tradução: Aurélio Guerra Neto e Célia Pinto Costa. Rio de Janeiro: Ed. 34, 1995a.

DELEUZE, Gilles; GUATTARI, Félix. Mil platôs: Capitalismo e esquizofrenia, v. 2. Tradução: Ana Lúcia de Oliveira e Lúcia Cláudia Leão. Rio de Janeiro: Ed. 34, 1995b.

DELEUZE, Gilles; PARNET, Claire. Diálogos. Tradução: Eloisa Araújo Ribeiro. São Paulo: Escuta, 1998.

FOUCAULT, Michel. O cuidado com a verdade. In: Ditos e escritos V: ética, sexualidade, política. Rio de Janeiro: Forense Universitária, 2004. p. 240-251. 
GALLO, Silvio. Diferenças, multiplicidade, transversalidade: para além da lógica identitária da diversidade. In: Alexsandro Rodrigues; Catarina Dallapicula; Sérgio Rodrigo S. Ferreira. (orgs.). Transposições - lugares e fronteiras em sexualidade e educação. 1. ed. Vitória: Edufes, 2014. p. 185-200.

GUATTARI, Félix. A transversalidade (1964). In: Psicanálise e transversalidade: ensaios de análise institucional. Aparecida, SP: Ideias \& Letras, 2004.

KNAAK, Bianca (org.). A(própria)ação entr\&tantas. Santa Maria: Autor, 2005.

LARROSA, Jorge. As crianças e as fronteiras: várias notas a propósito de três filmes de Angelopoulos e uma coda sobre três filmes iranianos. In: TEIXEIRA, Inês Assunção de Castro; LARROSA, Jorge; LOPES, José de Souza Miguel (orgs.). A infância vai ao cinema. Belo Horizonte: Autêntica, 2006.

LEITE, César Donizetti Pereira. Infância, Cinema e Educação - pesquisas com imagens para leitura além das margens. In: AMORIM, Antonio Carlos; WUNDER, Alik (orgs.). Leituras Sem Margens. 1. ed. Campinas SP: Leitura Crítica, 2014, v. 1, p. 205-226.

LEITE, César Donizetti Pereira; CHRISTOFOLETTI, Rafael. Pra quê cinema? O que pode o cinema na educação e a educação no cinema? Fronteiras de encontros. In: FRESQUET, Adriana (org.). Cinema e Educação: A Lei 13.006 - Reflexões, perspectivas e propostas. v. 1, Belo Horizonte: Universo Produção, 2015. p. 40-50.

MARCELLO, Fabiana de Amorim. Cinema e educação: da criança que nos convoca à imagem que nos afronta. Revista Brasileira de Educação, ANPED, v. 13, n. 38, p. 343-356, 2008. Disponível em: http://www.scielo.br/pdf/rbedu/v13n38/11. pdf. Acesso em: 10 set. 2019.

OLIVEIRA, Marilda Oliveira. O cinema como modo de pensamento, o cinema como forma de forçar a pensar. In: MARTINS, Raimundo; TOURINHO, Irene (orgs.) Pedagogias culturais. Santa Maria: Ed. da UFSM, 2014. p. 165-176.

OLIVEIRA, Marilda Oliveira de.; DAHMER, Carin Cristina. Entre tempos e história da arte: por um processo de apropriação. Eccos Revista Científica, São Paulo, n. 43, p. 69-83, maio./ago. 2017. Disponível em:

https://periodicos.uninove.br/index. php?journal=eccos\&page=article\&op=view\&path\%5B\%5D=7372. Acesso em: 10 set. 2019. 
PASSOS, Eduardo; BARROS, Regina Benevides de. Por uma política da narratividade. In: PASSOS, Eduardo; KASTRUP, Virgínia; ESCÓSSIA, Liliana (orgs.). Pistas do método da Cartografia: pesquisa-intervenção e produção de subjetividade. 4. reimp. Porto Alegre: Sulina, 2015, p. 150-171.

PASSOS, Eduardo; EIRADO, André do. Cartografia como dissolução do ponto de vista do observador. In: PASSOS, Eduardo; KASTRUP, Virgínia; ESCÓSSIA, Liliana (orgs.). Pistas do método da Cartografia: pesquisa-intervenção e produção de subjetividade. 4. reimp. Porto Alegre: Sulina, 2015, p. 109-130.

PELBART, Peter Pál. O avesso do niilismo - Cartografias do esgotamento. São Paulo: $n-1$ edições, 2016.

ROLNIK, Suely. Cartografia sentimental: transformações contemporâneas do desejo. Porto Alegre: Sulina; Editora da UFRGS, 2006.

VASCONCELLOS, Jorge. Deleuze e o Cinema. Rio de Janeiro: Moderna Ltda, 2006.

SPINOZA, Benedictus de. Ética. Tradução: Tomaz Tadeu. 2. ed. 5. reimp. Belo Horizonte: Autêntica Editora, 2016. 
$10.48209 / 978-65-89949-09-3$

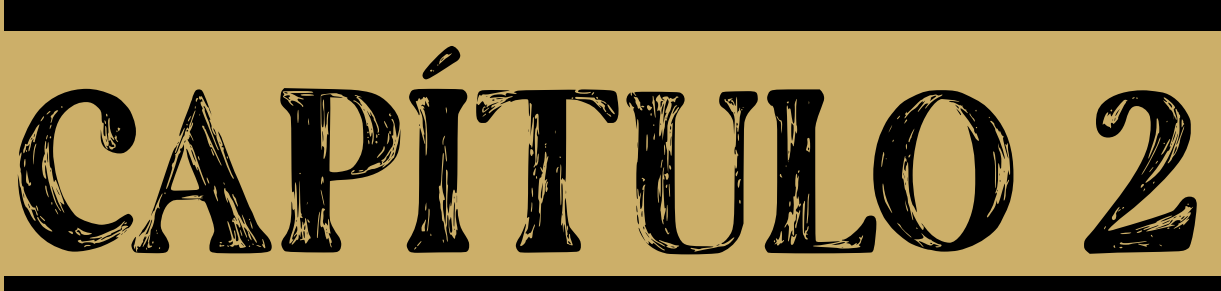

\title{
CONVITES DE ABERTURA AO OUTRO: COMPOSIÇÕES E EXPERIMENTAÇÕES COM CRIANÇAS RURAIS
}

\author{
Samara Facco ${ }^{1}$ \\ Alice Copetti Dalmaso ${ }^{2}$
}

1 Licenciatura Plena em Pedagogia (2020) pela Universidade Federal de Santa Maria (UFSM). Professora da rede municipal de ensino de Nova Palma, atuando na Educação Infantil.

E-mail:faccosamara8@gmail.com

2 Pós-Doutorado (2020) pelo Laboratório de Estudos Avançados em Jornalismo do Núcleo de Desenvolvimento da Criatividade, da Univer-sidade Estadual de Campinas (UNICAMP). Doutorado (2016) e Mestrado (2013) em Educação pela Universi-dade Federal de Santa Maria (UFSM). Bacharel (2008) e Licenciada em Ciências Biológicas (2010) pela Universidade Federal de Santa Maria (UFSM). Professora Adjunta no Departamento de Metodologia de Ensino da UFSM. E-mail:alicedalmaso@gmail.com 


\section{INTRODUÇÃO}

O presente trabalho consiste em produzir uma escrita que podemos chamar de ensaística ${ }^{7}$ e experimental, que se faz a partir de leituras, presenças, diálogos e afetações no modo de ser e estar em meio à livros, seres, autores, companhias multifacetadas, num contexto pandêmico, provocado pela presença do vírus Sars Covid-19 no mundo. Essa atmosfera pandêmica evocou a compor com a docência e as possibilidades de contaminações pelas existências das crianças, em meio ao contexto educacional da pandemia. Fluxos nada contínuos de experimentações foram se dando, movimentos de ensaiar-se como pesquisadoras em devir foram surgindo, imbricados com crianças pequenas de uma escola rural, permitindo-nos transitar pelo campo das artes e da vida, animadas por encontros com seres de toda ordem e natureza.

O ano de dois mil e vinte nos tirou o controle remoto das mãos, bem como as quatro paredes da escola e as certezas adultas da forma e da formação docente. Tivemos que aprender a renunciar a toda ordem e ânsia por controle. Nesse sentido, foi um ano onde aprendemos a emergir com mais potência diante da fragilidade da vida, angariando uma relação com um tempo que não passa, mas co-existe e perdura, fazendo-nos desacelerar o automatismo da vida moderna, fazendo-nos pensar e sentir os movimentos, os atravessamentos de vida, descontroles que envolvem a educação e o viver.

Por outro lado, ao mesmo tempo que fomos deixando de ocupar o espaço físico da escola presencial, fomos chegando nas casas de nossas crianças e famílias por outros fluxos, instalando novas maquinações corporais e subjetivas. Durante o ano de 2020, uma das autoras desta pesquisa acompanhou uma turma multisseriada da Pré-escola, localizada no interior do município de Nova Palma, Rio Grande do Sul (RS). Nessa experiência, fomos percebendo que muitas das nossas certezas e modos de fazer docentes foram colocados à prova, em risco.

7 " $[$ [...] o ensaio não adota a lógica do princípio e do fim, nem começa pelos princípios, pelos fundamentos, pelas hipóteses, nem termina com as conclusões, ou com o final, ou com a tese, ou com a pretensão de ter esgotado o tema. O ensaísta inicia no meio e termina no meio, começa falando do que quer falar, diz o que quer e termina quando sente que chegou ao final e não por que já nada resta a dizer, sem nenhuma pretensão de totalidade" (LARROSA, p. 112, 2003). 
A escola física tornou-se silenciosa e vazia, mas seus fragmentos foram parar nas casas dos estudantes e docentes, aumentando assim os enraizamentos/ vazamentos das propostas que fomos produzindo. Nesse novo nicho, fomos aprendendo que as possibilidades de invenções tomavam outros rumos, chegando e contaminando não apenas as crianças e os docentes na escola, mas também as suas famílias, possibilitando o que chamamos de produções/afetações em coletividade.

Partes dos escritos que aqui são expostos não se referem somente aos nossos percursos como pesquisadoras-docentes vivenciados até o presente momento, mas dizem respeito a tudo que nos é íntimo, que nos é singular e também plural, que afeta e compõe conosco. Dizem respeito, sobretudo, à intencionalidade da nossa narrativa, do lugar de docente experimentando com conceitos, afetando as crianças, mas sobretudo sendo afetada por seus devires, os quais, algumas vezes, por sorte, escorregam e habitam provisoriamente nossas forças vitais.

Junto dos processos vivenciados em condições remotas com as crianças, fomos impulsionadas por composições teórico-conceituais. Os respingos do conceito de devir-criança, bem como por noções de tempo-experimentação e modos de existência ameríndios, em consonância com vozes de DELEUZE (1997), DELEUZE e GUATTARI (1997), DALMASO (2014; 2020), KRENAK (2020), entre outros, surgem aqui para produzir novos caminhos junto das experiências vividas. Junto das vozes que nos lançam a diferentes perspectivas do pensar educação frente às multiplicidades, friccionamos algumas imagens de experimentações produzidas com as crianças de zona rural, não no sentido de ilustrar o que foi experienciado, mas a fim de lançar vetores de co-composição aos leitores. Desejamos que possam, ao seu modo, nos acompanhar na paisagem de vínculos produzidos nesses escritos.

\section{INFÂNCIAS, DEVIRES, COMPOSIÇÕES}

Em nossas instituições sociais e imaginários coletivos, estamos, de modo geral, mergulhados em concepções e modos de ser criança, operantes e vivas em nossa chamada ocidentalidade, as quais concebem a criança e sua infância 
costumeiramente projetada a partir do olhar adultocêntrico, que variam de representações que sustentam suposta 'salvação' futura da humanidade, dotada de ingenuidade e pureza, até seres sem consciência ou natureza espontânea para mudar o mundo ao seu redor. Independente de qual concepção é predominante, a grande questão é que sempre reside alguma expectativa e imposição sobre a criança e suas formas de viver a infância. Vivemos intensamente querendo controlar a autenticidade infantil, delimitar a pluralidade e ao mesmo tempo singularidade de forças pelas quais elas são capazes de compor seus devires no mundo, podando sua potência criadora.

Se trouxermos brevemente recortes históricos dos significados remetidos às crianças, veremos fortemente essas marcas de controle e esquecimento: "A criança vem da terra, do útero do mundo, do desconhecido mistério, mas ainda assim não entrou na vida" (PIORSKI, 2016, p.39). Delimitações entre ser divino ou padrão racionalista de instrução sempre fizeram parte das sociedades e nos acompanham até os dias atuais. Há aí uma concepção de que só participa realmente do mundo aquele que produz e é útil, no sentido produtivista e mecânico do capital, o qual usufrui da força dos corpos para extração de subjetividades úteis.

De todo modo, ainda persiste a consideração de que o estágio infante deve ser superado, em direção a um lugar a se chegar, cuja etapa de vida precisa ser moldada, amadurecida com os anos, até chegar à formatação 'completa' e adulta. Nesse sentido, a ideia de progresso atravessa também as instâncias educativas, influenciadas por algumas teorias da cognição, na qual o horizonte é a forma adulta de conhecer as coisas (KASTRUP, 2000).

Isso configura e permeia as muitas infâncias, roubadas, podadas e medicalizadas, por ir na contramão de tudo que designa ser aceitável para a idade e para a naturalização da vida ocidental como mercadoria (KRENAK, 2020). Designa a noção de uma infância 'errada', 'desajustada', em que o desejo de saber e inventar se torna 'um problema' de contratempo, pois enquanto adultos nos sujeitamos àquilo que dominamos, sem espaços para as perdas de tempo tão cheias de criação e afirmação ativa da vida (Figura 1).

8 De acordo com o autor Gandhy Piorski, em diferentes tempos e culturas "[...] existe uma estranha tendência a condenar as crianças ao esquecimento de si próprias" (PIORSKI, 2016, p.37) 
Figura 1 - Composição com coletas do chão

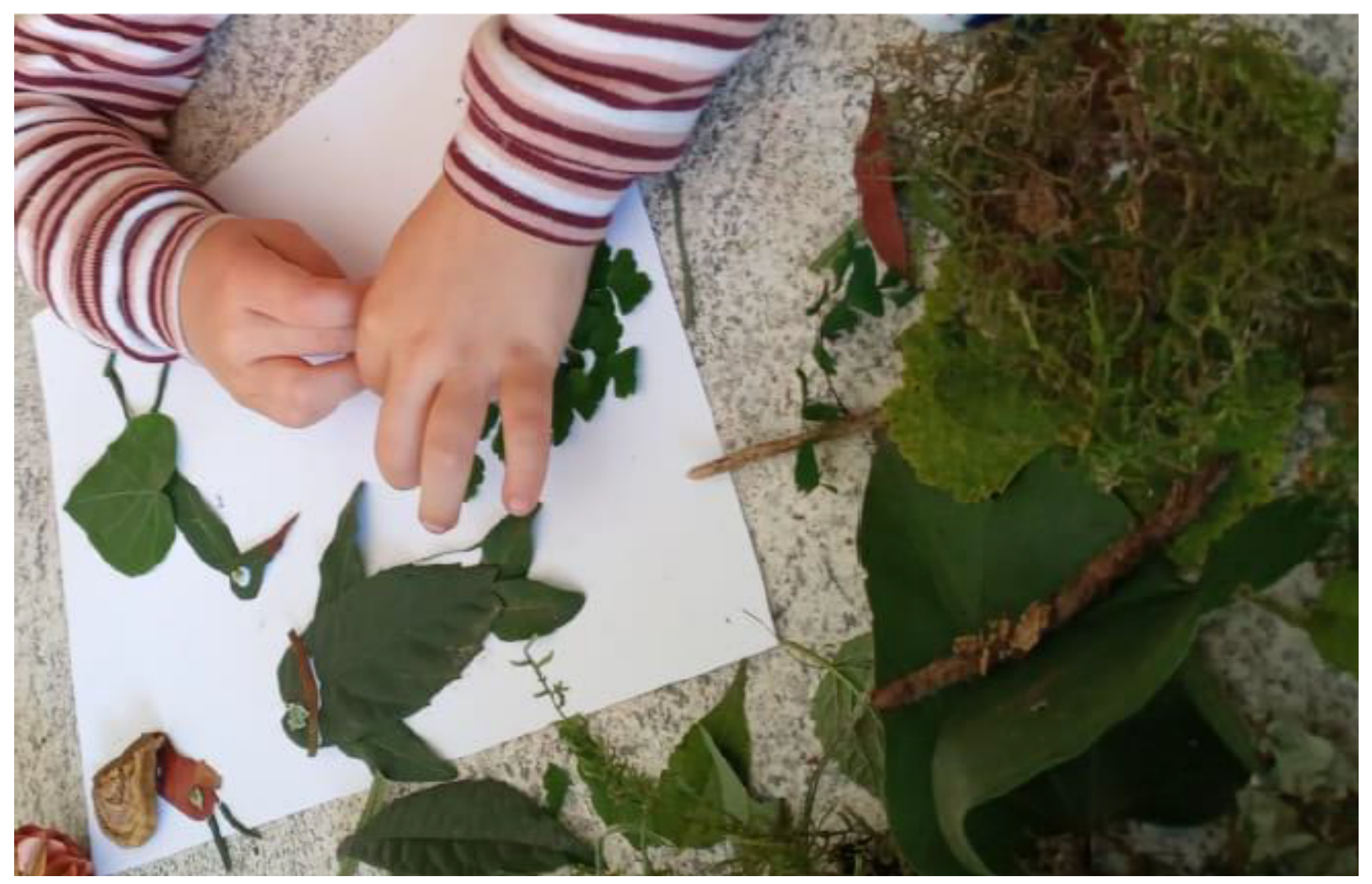

Fonte: As autoras

Toma relevo uma infância que agoniza diante das exigências e dispositivos escolares, os quais ajudam a alimentar e produzir um único modelo de ser e estar no mundo: o da obediência às normas, valores, códigos instituídos como certos, corretos, ideais. Porém, sabemos: são muitas as infâncias que existem, e podemos encontrá-las em muitas formas, cores e sabores em um só instante, cheias de criação e autenticidade. Entendemos que ser criança significa estar viva para o mundo (INGOLD, 2015) e está na natureza de tudo que é vivo a criação de si e da sua malha relacional. A educação, nesse sentido, pode potencializar ou desmobilizar essa dimensão intensiva e viva de existir.

Não buscamos com esses escritos instituir novas formas de se relacionar e ser provocado pela infância, mas sim (des)encontrar atravessamentos de vida possíveis nessas relações entre docência, devires das crianças, elementos da natureza e devires-criança em nós. Desejamos, como pontua Alberto Caeiro "[...] desembrulhar-me e ser eu" (PESSOA, 1946, p. 48). 
Por isso evocamos aqui algumas poucas elaborações a partir de um pensamento-criança, um devir-cognitivo, um modo de existir inspirado pelo conceito de devir-criança (DELEUZE; GUATTARI, 1997). Devir-criança remete a uma passagem, um atravessamento de vida que transcende qualquer matéria ou objeto. É um estado não sólido ou estável, que simplesmente acontece e nos acontece. Esse devir ultrapassa designações psíquicas-corporais de fases da vida humana, posto que consiste num estado de abertura e arrebatamento ao que chega, às forças incontáveis que habitam o mundo. Por isso, falar sobre os devires das crianças - e o devir criança em nós e fora de nós - trata de um viver despretensioso, sem projeções, expectativas, controles, conteúdos.

Um pensamento-criança é uma criança que se perde, que despreocupadamente, distrai-se com seus brincados, com seus desejos, que vive um tempo não cronológico, mas intensivo, onde a duração - e não a sucessão do tempo - são sentidos. Um devir-criança é essa sem regras, num desejo de despreocupação com códigos, que inventa um meio de fuga ao que se projeta sob ela com o ideal de infância, numa forma homem que deve atingir, num vir a ser mais do mesmo na vida (DALMASO, 2014, p. 9)

O que esse estado de abertura a tudo que transcende normas e modelos pode provocar na docência? Que alianças podem ser provocadas no contato com crianças e seus devires, a ponto de nos afetarmos por seus movimentos e modos de existir?

Como atentar ao que podemos aprender com uma (ou mais) crianças, sem romantizar 'uma infância' melhor, tampouco idealizá-la, mas tornando-nos, sobretudo, presentes em existir com ela, em presença desse ser? Arrisco afirmar, por ora: talvez levar a sério toda uma etologia da potência do estado sempre nascente, de uma força de engajamento no mundo, um corpo que mergulha em seu caos, engendrando um novo estado em devir, um corpo afirmado em sua própria diferença, estranheza e mistério (DALMASO, 2020, p. 3).

Ao ativar a experiência de presença e atenção às composições de vida de uma ou mais crianças, aprendemos a constituir a perspectiva fruitiva da existência, produzindo um conjunto de relações novas com as coisas e seres do mundo. O mundo, assim, já não é mais dado, e pronto a ser consumido (KRENAK, 2020): encontramos uma força vital para o que nos põe em abertura, para o que que se põe a nós, para ver as coisas rotineiras com outros olhos, olhos do encantamento que resiste à solidão e às faltas ampliadas provocadas por uma pandemia (Figura 2). 
Figura 2 - Composição com folhas

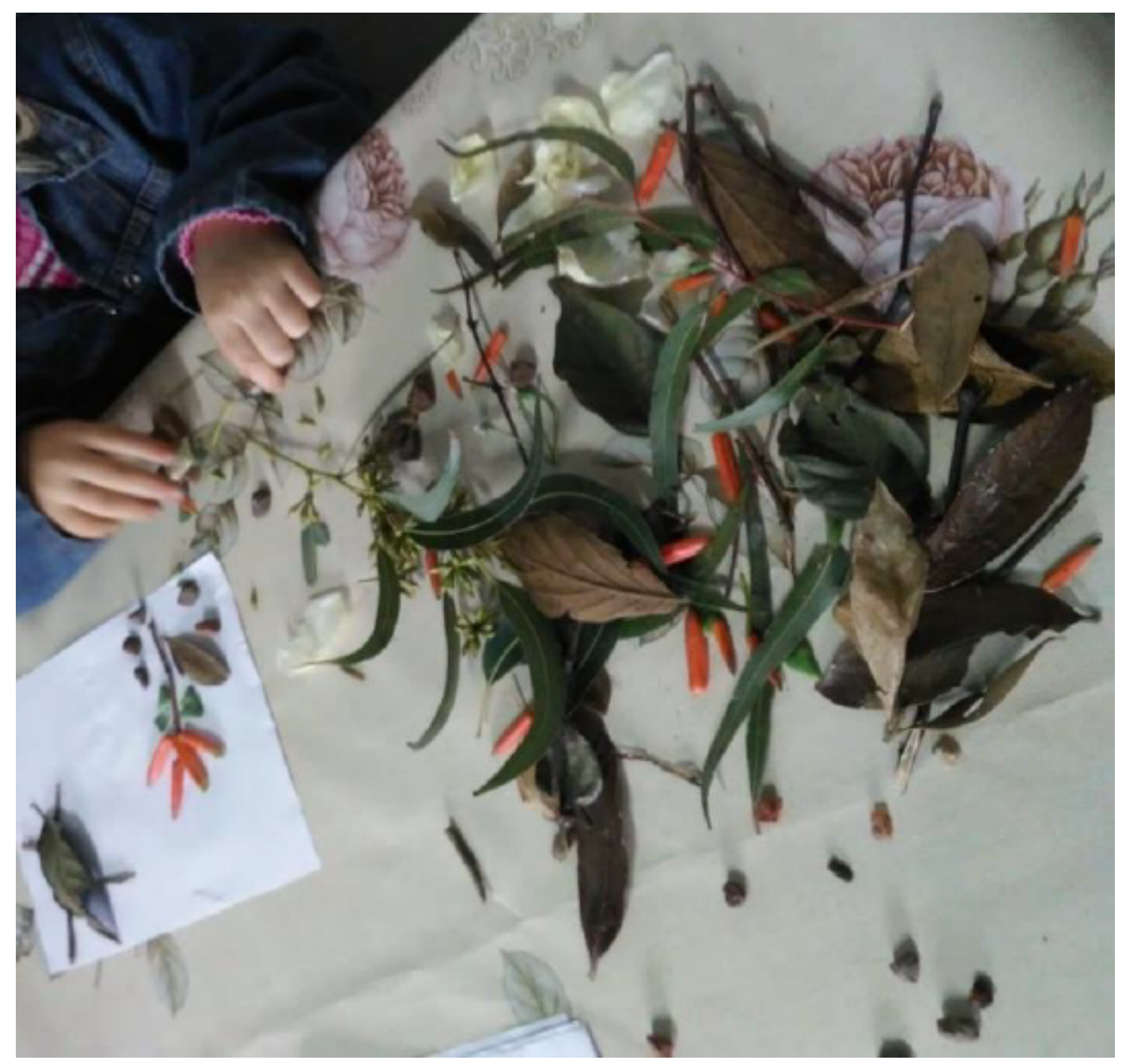

Fonte: As autoras

\section{UM CONVITE DE ABERTURA AO OUTRO}

Quando decidimos nos aventurar às possíveis afetações com as infâncias e suas invenções, percebemos que os binarismos inventados como humanos versus animais, ou natural versus artificial já não ocupavam tanto das nossas percepções. Nessa afetação, a vida parece crescer por todos os lados, posto que "[...] vida é transcendência, está para além do dicionário, não tem uma definição" (KRENAK, 2020, p.29). Nesse sentido, tudo se torna possibilidade de criação a partir da sensibilidade do estado infante, capazes de ver além do que se põe pela aparência dada das coisas.

Temos muito que aprender com as alianças não dadas, com a não separação de categorias entre cultura e natureza, posto que tudo se produz nessas tensões 
nas quais as naturezas produzem as culturas, as culturas se afetam e configuram novas naturezas, relações constituem uma malha ${ }^{9}$ ininterrupta, num nascimento e transformação contínua do mundo.

O que percebemos é que as crianças parecem constituir vividamente parcerias e misturas com tudo que as cerca (Figura 3), compondo com aqueles que são capazes de compor com elas, tornando vivos objetos inanimados, tornando a 'perda de tempo' a mais bela composição de suas próprias peles. O seu modo de vida que contempla uma aproximação com o outro e essa abertura para afetação com tudo que cohabita na terra, nos afeta como docentes, na medida que [...] A consciência de estar vivo deveria nos atravessar de modo que fôssemos capazes de sentir que o rio, a floresta, o vento, as nuvens são nosso espelho na vida (KRENAK, 2020, p.99-100)."

Figura 3 - Composição com a terra

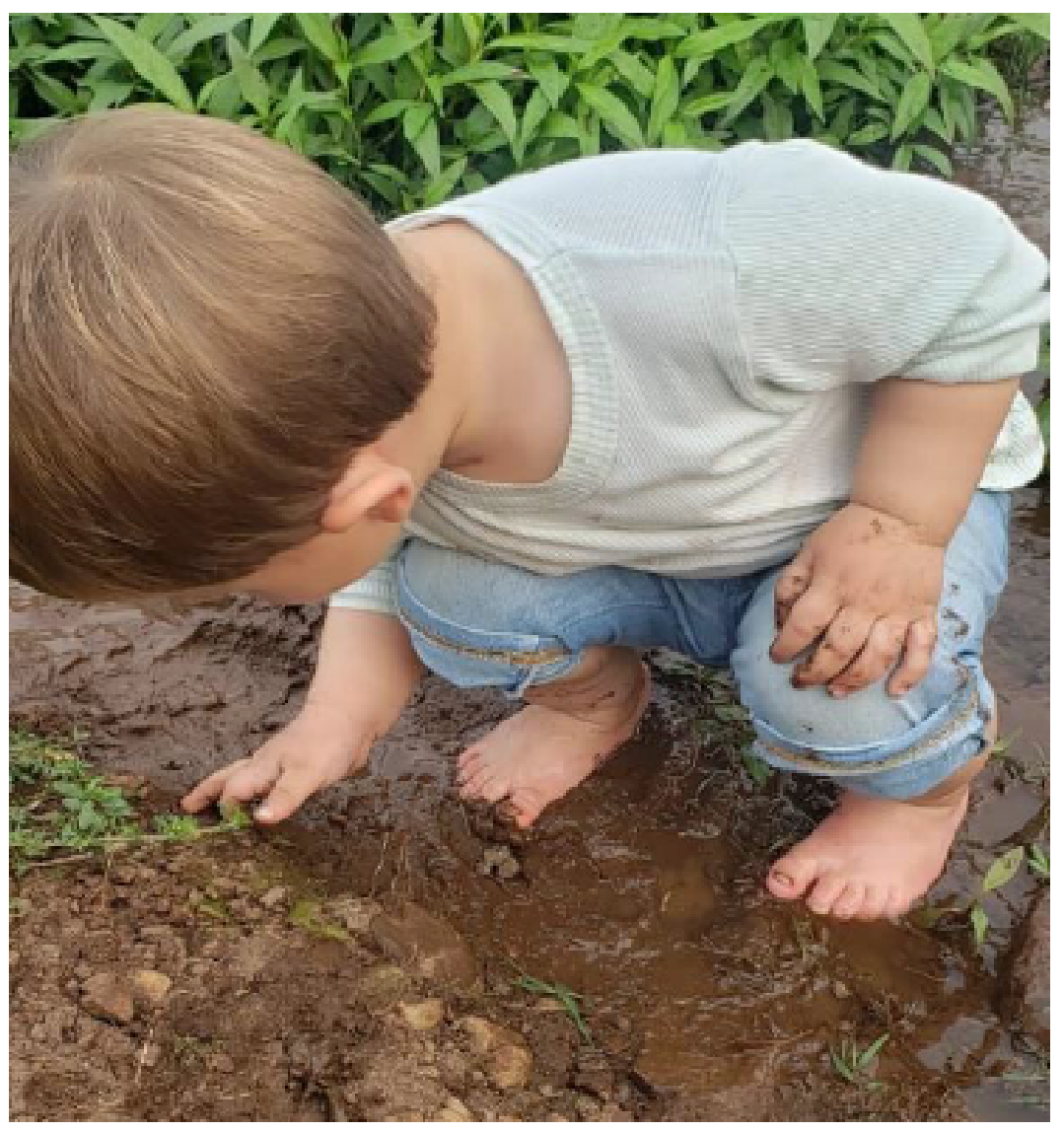

Fonte: As autoras

$9 \quad$ "Organismos e pessoas, então, não são tanto nós em uma rede quanto nós em um tecido de nós, cujos fios constitutivos, conforme se amarram a outros fios, em outros nós, compreendem a malha" (INGOLD, 2015, p. 120). 
Uma criança passa horas escolhendo pedras, aquelas que pisamos todos os dias em cima sem nenhuma abertura, testando a gravidade, a intensidade que cada uma produz ao cair na água, pegando uma, mas escolhendo devolver para a terra, pois ali embaixo é a 'casa das formigas'. Isso certamente é uma educação menor ${ }^{10}$, aquela que deixa-se tocar por aquilo que a maioria não se permite tocar, ver, ouvir. Compor com pedras, com terra, com matérias orgânicas e inanimadas, com luzes e sombras, com cheiros e texturas, fluidos e consistências.

Aos olhos do adulto, permanecer horas 'fazendo a mesma coisa'. Se nos abrirmos, porém, podemos perceber que a relação nunca se dá da mesma forma, ela está sempre acontecendo de modo outro no intervalo da repetição. Potência de criar dentro da própria realidade que se repete, imaginando e compondo com o que se apresenta como força de criação, posto que "[...] é no devir-criança que se vê a potência de criar tantos mundos dentro do próprio mundo" (BARIN, 2019, p. 91).

Acreditamos que tudo isso tem muito a nos ensinar sobre a potência do existir-criança, e também sobre o campo da formação docente, sempre ininterrupta e inacabada. Todas essas formas de afetação das subjetividades/pluralidades infantis têm muito a provocar em nossas ânsias e certezas adultas e docentes sobre controlar/limitar as crianças, porque sim, elas tem um potencial instituinte enorme. Mas elas escapam ao que quer se tornar instituído e formatado sobre ela, fazendo vazar as significações e as formas, sempre ampliando seu sentido de afetações de ordens menores e de pulsões de vida.

Na tentativa de militar na miséria do mundo dentro do nosso próprio deserto (KRENAK, 2020), é que propomos esses (des)encontros com a possibilidade de infâncias rurais criarem seus próprios brinquedos e composições (Figura 4), na relação com elementos de natureza viva.

10 Educação menor que não designa um ser menos, muito pelo contrário. Menor porque se caracteriza como uma educação das minorias e dos devires menores: infantis, potentes, contra-instituintes, com possibilidades de serem sempre outras e de promover afetação, provocação às normas e formas pré-estabelecidas dos sujeitos. Uma educação das minorias, aqui sendo as infantis, afirmadas em suas subjetividades múltiplas e plurais (GALLO, 2013). 
Figura 4 - Composições com o outro

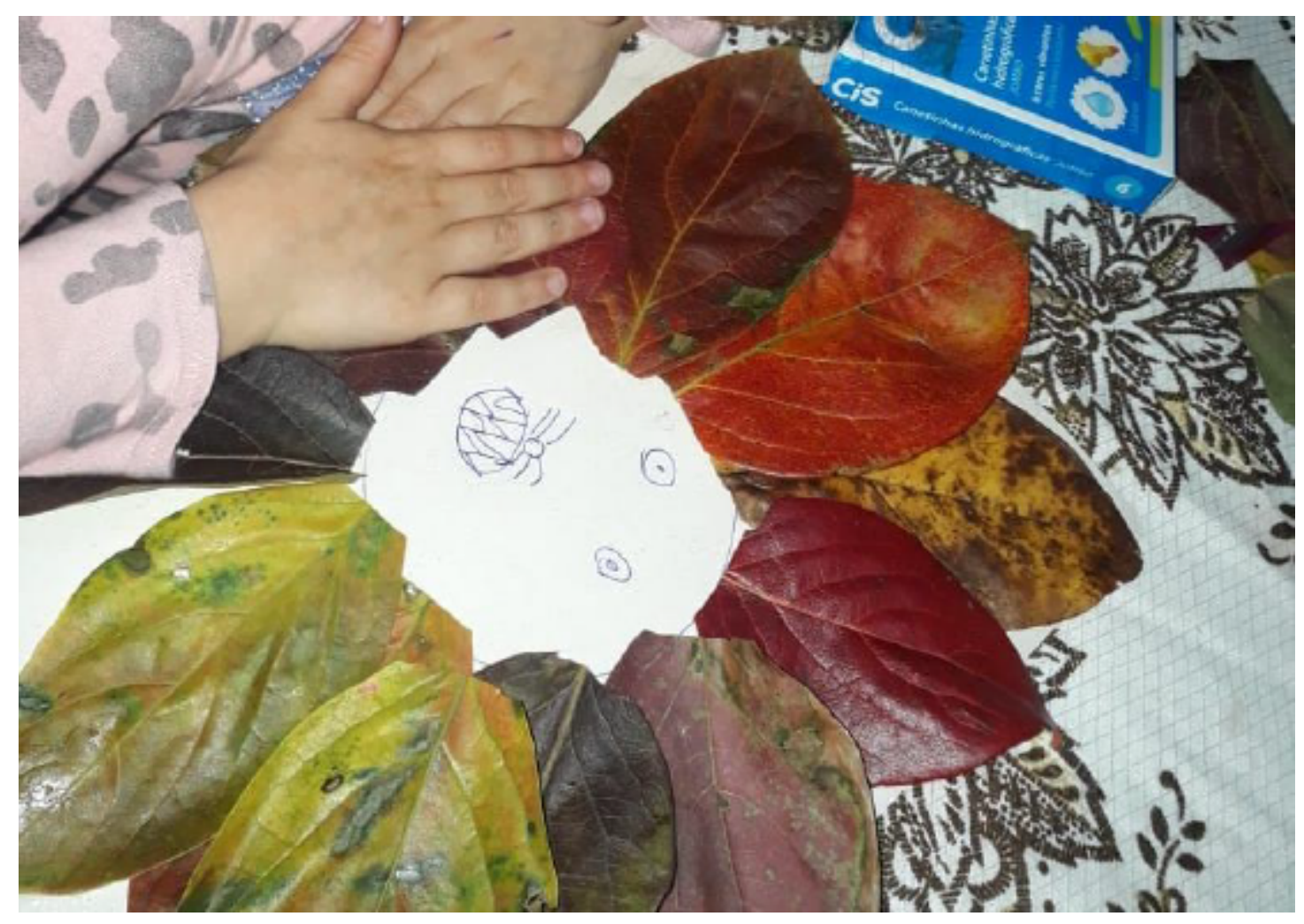

Fonte: As autoras

O que somos capazes de resgatar da nossa natureza mais íntima através do contato e abertura para outro ser vivo? Chamamos aqui de vivo não só os seres 'animados' mas também aqueles que produzem vida em nós, que constituem uma existência, a qual testemunhamos (LAPOUJADE, 2017) e nos convoca um olhar apurado, disparando sensações, um respiro cheio de oxigênio para o corpo.

A vida atravessa tudo, atravessa uma pedra, a camada de ozônio, geleiras. A vida vai dos oceanos para a terra firme, atravessa de norte a sul, como uma brisa, em todas as direções. A vida é esse atravessamento do organismo vivo numa dimensão imaterial (KRENAK, 2020, p. 28).

Quando a criança se conecta e compõe com o ambiente, com uma pedra, como já mencionamos, várias pedras são lançadas na água, de vários tamanhos, formatos, texturas e pesos, algumas até pesadas demais para serem lançadas, mas mesmo assim experimentadas. Nesse momento já não é mais necessário delimitar o que é o elemento e o que é o indivíduo, porque eles já não são mais os mesmos, eles são a relação entre o que os acontece e os faz diferir nessa re- 
lação. Um processo que não controlamos, que tentamos pegar e logo nos escapa novamente, um surgir na relação de abertura com os heterogêneos ${ }^{11}$ da natureza.

A criança não para de dizer o que faz ou tenta fazer: explorar meios, por trajetos dinâmicos, e traçar o mapa correspondente. (...) O trajeto se confunde não só com a subjetividade dos que percorrem um meio mas com a subjetividade do próprio meio, uma vez que este se reflete naqueles que o percorrem. O mapa exprime a identidade entre o percurso e o percorrido. Confunde-se com seu objeto quando o próprio objeto é movimento (DELEUZE, 1997, p.73).

É a partir dessa mistura corpórea-relacional entre a criança e o que chamamos de mundo que novos processos de aprendizagem acontecem: um jeito de existir que nos obriga, quando em suas presenças, a nos conectarmos com algo além de nós, obrigando-nos, às vezes à fórceps, a sairmos de um ensimesmado eu. Para onde isso pode nos levar?

\section{PARA NÃO CONCLUIR}

Experimentamos nesses fluxos de vida, em meio a pandemia, um tempo que passou, passa e nos afeta de maneira diferente. Um tempo que nos obriga a sentir os descontroles da vida e da educação, as sutilezas e também os terremotos da nossa existência.

As relações e imbricamentos possíveis entre as infâncias produzidas em meio rural, fez surgir em nós devires-mundo, passagens de pulsão de vida, sem freios de sermos levadas a lugares nada confortáveis de docência. Uma docência que se permitiu respingar pelos modos infantis de viver. Se relacionar com a vida com certa abertura ao outro que, diferente de nós, nos põe a criar novas relações de vida e existência.

Encontrar esse tempo outro que procuramos discorrer nestes escritos nos fez angariar maneiras de descobrir o poder ativo de coisas, seres, palavras, ges-

11 Conceito tomado emprestado a partir dos escritos da tese da pesquisadora Angélica Neuscharank (2019), na qual muito bem descreve: "[...] dissolver esse modo de existências que desqualifica o informe, o imprevisto, o incerto, o instável e o incalculável da vida", encontrando e se relacionando com aquilo que foge do instituído enquanto desenho, imagem, representação de mundo, "[...] coisas que ainda não tomaram forma e sentido, e que talvez nem tomem, que não são classificadas por certo ou errado, preciosas ou descartáveis, binarismos pueris que nos levam a juízos de valor" (NEUSCHARANK, 2019, p.31) 
tos, cheiros, vistos e testemunhados na conjunção, combinação, de um estar junto das crianças. O intervalo Covid-19 em nossas vidas nos fez intervalar naquilo que se instaurava em seu poder ativo de nos fazer pensar e sentir a partir de um novo lugar. Uma diferença, um estranhamento novo se fazia, ainda que não soubéssemos exatamente por quais vias acentar. Era aí que se dava um novo processo de aprendizagem em nós, professoras, agora desanestesiadas do automatismo e dispostas a inventar algo novo de nós mesmas.

Trata-se sempre de um expor-se, abrir-se e atentar-se, uma pele que cresce, uma superfície corporal-perceptivo que expande, para compor "Um cenário de vínculos, uma conexão visível-invisível" (DALMASO, p. 23, 2020), as quais as crianças são capazes de por em relação, junto dos devires que desencadeiam no mundo e em nós. É como se pudéssemos atingir as linhas que se emaranham e se tornam interdependentes, num movimento de geração contínua das relações em formação. Através delas, nos espantamos, sentindo o pulsar de um mundo que nasce a nossa frente, num maravilhamento sem pudor.

As crianças e suas composições nos fazem apostar nisso que se abre a partir de uma pandemia mundial: a de não machucar, furar e arranhar com tanto peso e descontrole o lugar por onde pisamos (KRENAK, 2020), os rastros de atividade que deixamos no mundo (INGOLD, 2015). Não pisar descontroladamente sobre o chão implica atentar ao que temos feito de nossos corpos e mentes, de nossas ações e gestos, pensamentos e palavras. É assim que uma criança em seu meio nos convida a partilhar a maravilha da existência que pisa mais manso, num tempo que se experimenta. Alegres, entendemos que podemos nos postar dignos desse convite. Parece-nos que esse tem sido o grito que ecoa em nossos corações. Esse texto fez parte desse convite e dos ecos de nosso peito. 


\section{REFERÊNCIAS}

BARIN, Ana Cláudia. Invento-me: potências do devir-criança-uma educação pela fabulação. Santa Maria: UFSM, 2019. Tese (Doutorado em Educação), Centro de Educação, Universidade Federal de Santa Maria, 2015.

DALMASO, Alice. Literatura e devir-criança: experimentações e agenciamentos para pensar a educação. Anais da X ANPED SUL, Florianópolis, outubro de 2014. Disponível em: <http://xanpedsul.faed.udesc.br/arq_pdf/1326-0.pdf>. Acesso em: 25. jun. 2021.

DALMASO, Alice. Quando o sol é tão forte como um mel: experimentações de existir -escrever, pensar, comunicar - com crianças. Revista ClimaCom. Campinas, ano 7, n. 18, 2020. Disponível em: <http://climacom.mudancasclimaticas.net. br/wp-content/uploads/2020/09/ARTIGO-8-Quando-o-sol----t--o-forte.pdf>. Acesso em: 25. jun. 2021.

DELEUZE, Gilles. Crítica e clínica. São Paulo: Ed 34, 1997.

DELEUZE, Gilles; GUATTARI, Félix. Mil Platôs: capitalismo e esquizofrenia. Vol. 4. 1a ed. São Paulo: Editora 34, 1997.

GALLO, Silvio. Em torno de uma educação menor: variáveis e variações. Anais da $36^{\circ}$ Reunião Nacional da ANPED - Goiania -GO, Set/2013.

INGOLD, Tim. Estar vivo: ensaios sobre movimento, conhecimento e descrição. Petrópolis: Vozes, 2015.

KASTRUP, Virgínia. O Devir-criança e a Cognição Contemporânea. Rio de Janeiro. Revista Psicologia: Reflexão e crítica, 2000.

KRENAK, A. A vida não é útil. São Paulo: Companhia das Letras, 2020.

LAPOUJADE, D. As existências mínimas. São Paulo: n-1 edições, 2017.

LARROSA, Jorge. O ensaio e a escrita acadêmica. Revista Educação e Realidade, v. 28, n. 2, jul/dez 2003, p. 101-115. Disponível em: <https://seer.ufrgs.br/ educacaoerealidade/article/view/25643>. Acesso em: 09 jul. 2021.

PESSOA, Fernando. O Guardador de Rebanhos, In Poemas de Alberto Caeiro. Lisboa: Ática. 1946 (10ª ed. 1993). p. 48.

PIORSKI, Gandhy. Brinquedos do chão: a natureza, o imaginário e o brincar. São Paulo: Peirópolis, 2016. 


\title{
$10.48209 / 978-65-89949-09-4$
}

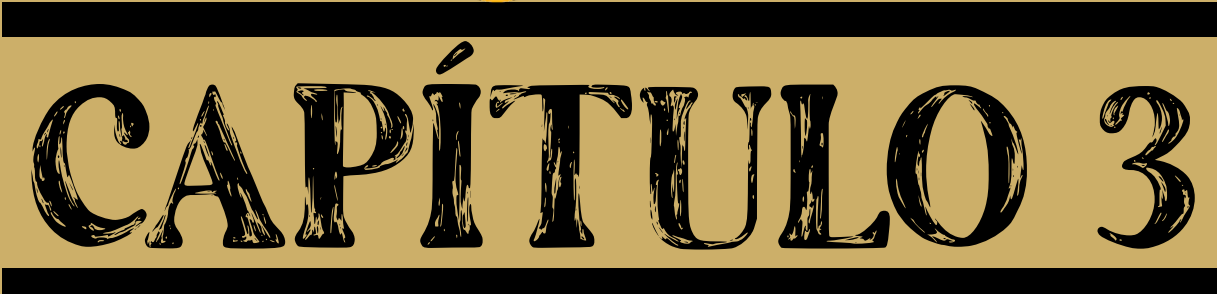

\section{PANDEMIA E EDUCAÇÃO: DESAFIOS NA FORMAÇÃO INICIAL EM ARTES VISUAIS}

\author{
Eduarda Teixeira Streck ${ }^{1}$ \\ Rute Abadie Fernandes ${ }^{2}$ \\ Stefani Souza de Jesus ${ }^{3}$
}

1 Graduanda Artes Visuais - Licenciatura/UFSM, membra do grupo de Pesquisa MIRARTE, bolsista PIBID/UFSM (2018-19) e Residência Pedagógica/UFSM (2020-).

http://lattes.cnpq.br/3026815399626828.E-mail: eduardastreck@gmail.com

2 Graduanda Artes Visuais - Licenciatura/UFSM, membra do grupo de Pesquisa MIRARTE, bolsista PIBID/UFSM (2018-19) e Residência Pedagógica/UFSM (2020-).

http://lattes.cnpq.br/3016998861105366. E-mail: fernandesrute14@gmail.com.

3 Graduanda Artes Visuais - Licenciatura/UFSM, membra do grupo de Pesquisa MIRARTE, bolsista PIBID/UFSM (2018-19) e Residência Pedagógica/UFSM (2020-).

http://lattes.cnpq.br/4337769087679453.E-mail: stefani211souza@hotmail.com. 


\section{INTRODUÇÃo}

A pandemia mundial do novo coronavírus (Sars-Cov-2) foi declarada pela Organização Mundial de Saúde (OMS), como surto global em 11 de março de 2020. Em pouco tempo o mundo precisou adequar-se, e medidas foram acionadas para barrar o avanço da nova doença, que até aquele momento pouco se tinha conhecimento. O uso de máscaras, álcool em gel e distanciamento social, rapidamente passaram a fazer parte do nosso cotidiano, submetendo-nos a uma abrupta adaptação ao 'novo normal'.

Quando o Brasil declarou 234 casos confirmados de infectados pelo novo coronavírus $^{12}$, sendo 8 casos no Rio Grande do Sul, o Governador do estado, Eduardo Leite, decretou o cancelamento das aulas presenciais, nas instituições de ensino públicas e privadas. De maneira conturbada e com pouco planejamento, implantou-se o Ensino Remoto ${ }^{13}$ como uma alternativa emergencial, reduzindo a educação em aulas ministradas a distância, através de materiais impressos e plataformas digitais ${ }^{14}$. Professores e estudantes precisaram reinventar-se para darem continuidade ao ano letivo. No entanto, compreendemos que em um país com tantas desigualdades sociais como o nosso, onde grande parte dos estudantes não possuem acesso, torna-se ainda mais difícil seguir frequentando as aulas e como agravante, nos deparamos com professores extremamente esgotados, por não possuírem um letramento digital adequado para ministrar as aulas.

No atual cenário que estamos inseridas, há mais de um ano de pandemia, percebemos que,

12 Governo do RS suspende aulas da rede estadual a partir desta quinta devido ao coronavírus. G1 RS, Porto Alegre, 16 de mar. de 2020. Disponível em: https://g1.globo.com/rs/ rio-grande-do-sul/noticia/2020/03/16/governo-do-rs-suspende-aulas-da-rede-estadual-a-partir-desta-quinta-devido-ao-coronavirus.ghtml. Acesso em: 20 de mai. de 2021.

13 O ensino é considerado remoto porque os professores e alunos estão impedidos por decreto de frequentarem instituições educacionais para evitar a disseminação do vírus. É emergencial porque do dia para noite o planejamento pedagógico para o ano letivo de 2020 teve que ser engavetado. DUTRA, Flávia. Artigo: O Ensino Remoto Emergencial e a Educação a Distância. Universidade Federal do Rio Grande do Sul, Porto Alegre, 6 de jun. de 2020. Disponível em: https://www.ufrgs.br/coronavirus/base/artigo-o-ensino-remoto-emergencial-e-a-educacao-a-distancia/. Acesso em: 20 de mai. de 2021.

14 Plataforma digital implantada oficialmente em todas as escolas do estado do Rio Grande do Sul: Google Classroom. 
Estamos vivendo tempos difíceis com o COVID-19, a pandemia contemporânea mostra-se globalizada e expõe que é necessário desenvolver, urgentemente, políticas públicas de igualdade educacional, pensando em ações voltadas para a preservação da dignidade, identidade cultural, do respeito à diferença e inclusão dos alunos, que encontram-se nesse momento privados do direito que é garantido pela Constituição Federal. (BARRETO; ROCHA, 2020, p. 9)

Mesmo com sinais de esperanças, com a primeira pessoa vacinada contra o Covid-19, em janeiro de 2021, entendemos que esta situação caótica está longe de acabar. A fila de vacinação caminha a passos lentos, de acordo com o jornal O Globo ${ }^{15}$, no ritmo de vacinação em que estamos, apenas em 2024 conseguiríamos vacinar $70 \%$ da população brasileira. Faltam vacinas, planejamento, logística e investimentos. Nos perguntamos, como fica a educação?

De acordo com a Base Nacional Comum Curricular (2017), referência obrigatória para o planejamento dos currículos da rede básica de ensino, todos os estudantes, sejam eles, das instituições de ensino pública ou privada, devem possuir um ensino padronizado e igualitário. Salientando o que diz na nossa própria Constituição Federal (1998), no artigo 255, que a educação é um "direito de todos e dever do Estado e da família". Novamente nos perguntamos, será que estamos cumprindo e colocando em prática os documentos basilares que norteiam a educação brasileira?

Nesta escrita, procuramos refletir uma docência que se constrói em meio ao caos, a partir do compartilhamento de experiências vivenciadas por nós, autoras, estudantes do $7^{\circ}$ semestre da disciplina de Estágio Supervisionado, do Curso de Licenciatura em Artes Visuais, da Universidade Federal de Santa Maria, localizada ao sul do país. Semelhante aos estudantes da rede básica de ensino que estão sendo atravessados pelos desafios de uma formação mediada pelos meios digitais, nós, docentes em formação, enquanto estagiárias, também ficamos imersas nesta 'teia', onde o caos prevalece. Não encontramos alunos, encontramos ícones/números através da tela do computador. Temos o contato, mas não conseguimos estabelecer relações reflexivas, críticas e afetivas, na maioria das vezes,

$15 \quad$ No ritmo atual, Brasil só conseguirá vacinar $70 \%$ da população em 2024. O Globo, Rio de Janeiro, 07 de fev, de 2021. Disponível em: https://oglobo.globo.com/sociedade/coronavirus/ no-ritmo-atual-brasil-so-conseguira-vacinar-70-da-populacao-em-2024-24871905. Acesso em: 20 de mai. de 2021. 
acabamos apenas cumprindo uma tarefa.

Devemos salientar, que não procuramos respostas exatas e completas para os questionamentos abordados no decorrer desta escrita, nossa intenção é refletir sobre a formação inicial em Artes, no qual não fomos atravessadas 'apenas' pelo novo coronavírus, mas também, pelos medos e anseios que reverberam no ser docente e que foram intensificados pelo novo modelo de ensino.

\section{ENSINO REMOTO: UMA EDUCAÇÃO VIRTUAL}

Enquanto docentes em formação inicial, pensar a inserção no ambiente escolar como futuras professoras gera incertezas e inseguranças, pois é no Estágio Supervisionado que de fato ocorrem os primeiros contatos com a escola. Contatos, entre professores e estudantes, que possibilitam uma aproximação e familiarização essencial, para que os discentes consigam pôr em prática o que vem estudando desde o início da formação em licenciatura. Por sua vez, escolher a área da educação é desafiador, pois requer constantes atualizações no que se refere a acompanhar as transformações que o mundo passa a enfrentar. Trata-se de aprender para ensinar, e ensinar para aprender, como afirma Freire, "Quem ensina aprende ao ensinar e quem aprende ensina ao aprender" (1997, p.13).

Com a pandemia de Covid-19, desde o ano de 2020 passamos a enfrentar danos imensuráveis como a perda de incontáveis vidas, superlotação de hospitais e instituições de saúde, crise econômica e educacional (tema selecionado para a reflexão); dentre outras inúmeras áreas que foram afetadas. Nesse contexto, com a área da educação abruptamente atingida, resultou no afastamento de estudantes e professores, devido a implantação do distanciamento social como uma alternativa sanitária para evitar a transmissão desenfreada da doença. Diante dessa nova realidade, a educação ficou em colapso, no quesito de continuar garantindo o direito ao ensino em meio ao caos que passamos a enfrentar.

O Ensino Remoto implantado pela Secretaria da Educação do Rio Grande do Sul (Seduc RS), foi a alternativa emergencial possível para continuação das aulas, mesmo que de modo limitado. Como agravante, o Brasil possui um alto nível de desigualdade social e uma educação precária, que atinge principalmente os alunos de instituições públicas. Desse modo, desde o início do atual modelo de 
ensino, houve um aumento na desistência dos estudantes. Segundo o relatório intitulado, "Enfrentamento da cultura do Fracasso Escolar", publicado pelo Fundo de Emergência Internacional das Nações Unidas para Infância (Unifec) ${ }^{16}$, no Brasil cerca de 5,5 milhões de crianças e adolescentes entre 6 e 17 anos, abandonaram os estudos durante a pandemia, somando aos 4,12 milhões de estudantes, que estão matriculados, porém não possuem acesso às atividades escolares.

No entanto, diante dos altos níveis de evasão escolar, os professores também vêm passando por dificuldades de adaptação nesse novo modelo de ensino. De desdobrar-se para desenvolver uma educação capaz de proporcionar o mínimo de proveito para os estudantes, para que consigam aprender e apreender o que lhes está sendo proposto.

A Nota Técnica ${ }^{17}$ lançada em abril de 2020 pela organização civil, "Todos pela Educação", referente ao ensino a distância na educação básica durante a pandemia, nos diz que,

No Brasil, apesar de a grande maioria dos professores (76\%) terem recentemente buscado formas para desenvolver ou aprimorar seus conhecimentos sobre o uso das tecnologias para auxiliar nas aulas, apenas $42 \%$ indica ter cursado alguma disciplina sobre o uso de tecnologias durante a graduação, e somente $22 \%$ participaram de algum curso de formação continuada sobre o uso de computadores e internet nas atividades. Consequentemente, $67 \%$ dos docentes alegam ter necessidade de aperfeiçoamento profissional para o uso pedagógico das tecnologias educacionais. (Todos pela Educação, 2020, p. 13)

Podemos afirmar, que acabamos sendo inseridas neste grupo de docentes que não possuem formação para o uso de tecnologias digitais no ambiente escolar, resultando na falta de preparo para atuar no Ensino Remoto. Acreditamos que devemos criar consistentemente uma nova cultura do magistério na perspectivade que o uso das tecnologias não seja algo exógeno à docência, mas inerente a ela e necessário ao processo abrangente de formação integral do ser humano. (AMARAL; GARCIA; RABELO e SILVA, 2011, p. 80)

16 Cultura do fracasso escolar afeta milhões de estudantes e desigualdade se agrava na pandemia, alertam UNICEF e Instituto Claro. Unicef Brasil, 2021. Disponível em: https://www. unicef.org/brazil/comunicados-de-imprensa/cultura-do-fracasso-escolar-afeta-milhoes-de-estudantes-e-desigualdade-se-agrava-na-pandemia. Acesso em: 20 de mai. de 2021.

17 Nota técnica ENSINO A DISTÂNCIA NA EDUCAÇÃO BÁSICA FRENTE À PANDEMIA DA COVID-19. Todos pela Educação, 2020. Disponível em: https://www.todospelaeducacao.org. br/_uploads/_posts/425.pdf. Acesso em: 20 de mai. de 2021 
Dentre tamanhos desafios educacionais, nos encontramos numa situação bilateral: como estudantes do ensino superior em adaptação ao novo modelo de ensino; e como docentes em formação inicial em momento de inserção no meio escolar. Desse modo, intentamos evidenciar como essas mudanças na educação devido a pandemia do Covid-19 têm afetado também os docentes em formação inicial, e quais têm sido os principais desafios e consequências.

Mesmo que o Ensino Remoto possibilite a continuação do ensino, obviamente não se pode comparar com o Ensino Presencial e, para nós, também se torna mais um empecilho. Não se trata apenas de distanciamento físico, mas intelectual. Há uma grande barreira entre nós, professoras e eles, os alunos. O modo como aprendemos a nos preparar para adentrar a sala de aula, nos foi impossibilitado rapidamente e a necessidade de nos reinventarmos sem ao menos ter a oportunidade de conhecer o espaço escolar. Como nos diz Danilo Zajac (2021) para o site "A Escola Preparatória da UFABC18":

Até a relação professor-aluno se modifica neste processo: o processo de ensino-aprendizagem, que reforça um vínculo importante entre o que aprende e o que ensina, hoje é apresentado apenas como aprendizagem. A responsabilidade pelo aprendizado continua sendo da escola e dos professores, mas assim como nas relações de mercado, quem vende a mercadoria, onde se vende e como se vende não é tão fundamental, desde que ela seja oferecida com suposta qualidade.

Enquanto docentes em formação em Artes Visuais, nos deparamos com situações que nos atravessa de modo a refletir como o Ensino Remoto impacta a formação docente, mas também o ensino de Artes Visuais. Compreendemos que a educação em si tem enfrentado lacunas que abrange a todas áreas que a compõem, mas buscamos evidenciar como a nossa área vem sendo atingida. Dentre as questões pontuadas, nos encontramos imersas a tentar desenvolver um ensino que acolha os estudantes, que para eles, seja mais que uma disciplina, que se torne um espaço de compartilhamentos e experimentações, e consequentemente nos traga frutos para agregar na nossa formação inicial. No entanto, essa perspectiva encontra-se em conflito, pois está sendo difícil encontrar maneiras de

18 ZAJAC, Danilo. Ensino remoto na Educação Básica e Covid-19: um agravo ao Direito à Educação e outros impasses. Escola Preparatória da Universidade Federal do ABC, Pró-Reitoria de Extensão e Cultura, 2021. Disponível em: Ensino remoto na Educação Básica e COVID-19: um agravo ao Direito à Educação e outros impasses - Escola Preparatória da UFABC. Acesso em: 15 abr. 2021. 
atraí-los, de contemplar a todos e muitas vezes, como já ouvimos falar que "é uma disciplina de Artes, tem que se reinventar, buscar alternativas..." mas entendemos que a realidade não funciona assim.

\section{ARTES VISUAIS: DOCÊNCIA EM FORMAÇÃO EM TEMPOS DE PANDEMIA}

A partir da implementação do Ensino Remoto nas instituições de ensino, necessitou-se encontrar uma possível docência em Artes Visuais. Resultando na necessidade de reorganizar o que entendíamos como espaço escolar, e em consequência disso, as práticas formativas no Estágio Supervisionado acabaram sendo adaptadas ao 'novo normal'. De acordo com a Lei № 11.788 , de 25 de Setembro de 2008 , define em seu Artigo $1^{\circ}$ que o

Estágio é ato educativo escolar supervisionado, desenvolvido no am-
biente de trabalho, que visa à preparação para o trabalho produtivo de
educandos que estejam freqüentando o ensino regular em instituições de
educação superior, de educação profissional, de ensino médio, da edu-
cação especial e dos anos finais do ensino fundamental, na modalidade
profissional da educação de jovens e adultos. (BRASIL, 2008)

Diante desta situação, se torna fundamental elucidar a importância do Estágio Supervisionado para os graduandos em licenciatura, para vivenciar as diferentes nuances do que é estar diante de uma sala de aula, de ser o responsável de instigar e abranger as particularidades de cada estudante que a compõe. Se trata de relações, conexões, ensinamentos e aprendizagens. Entretanto, o que acontece quando esses enlaces se encontram rompidos?

No contexto da Universidade Federal de Santa Maria - RS, o Estágio Supervisionado do Curso de Artes Visuais, no qual estamos inseridas, movimenta-se concomitantemente com a Residência Pedagógica. Programa de aperfeiçoamento, que integra as Políticas Nacionais de Formação dos professores, onde o licenciando inicia sua imersão na sala de aula de maneira autônoma. Porém, o Ensino Remoto nos trouxe novas disposições para tal dinâmica. Começando com a inserção nas turmas, que passou a acontecer de modo virtual. As aulas semanais tornaram-se encontros quinzenais, dificultando a interação com os estudantes. A hora-aula teve seu tempo reduzido, e consequentemente tais mudanças ocasio- 
naram uma participação quase inativa dos estudantes. Os pontos mencionados acima tencionaram reflexões sobre a nova maneira de lecionar em tempos pandêmicos.

A Lei N 11.788 fomenta no segundo inciso que "O estágio visa ao aprendizado de competências próprias da atividade profissional e à contextualização curricular, objetivando o desenvolvimento do educando para a vida cidadã e para o trabalho." (BRASIL, 2008). Mas será que estamos desenvolvendo tal competência em meio ao contexto do Ensino Remoto? Estagiários encontram no Ensino Remoto um ambiente virtual, em que o tempo é acelerado, com aulas curtas e objetivas. O período de aula no Ensino Presencial tinha duração de 45 minutos e havia a participação e frequência dos alunos, situação oposta com o Ensino Remoto, pois a aula teve seu tempo reduzido a 30 minutos (devido a multifuncionalidade da internet que ocasiona a distração dos estudantes) e a baixa participação dos alunos reduzem ainda mais o tempo de aula que já é escasso. Desse modo, não há espaço para o desenvolvimento da reflexão crítica, do trabalho coletivo e do debate entre estudantes e professores.

Isso nos leva a pensar no que Paulo Freire denominou de Educação bancária, no qual o aluno é visto como um banco, onde o professor deposita o conhecimento, não havendo espaço para o educando reverberar o que está sendo aprendido.

(...) a educação se torna um ato de depositar, em que os educandos são os depositários e o educador o depositante (...) Eis aí a concepção "bancária" da educação, em que a única margem de ação que se oferece aos educandos é a de receberem os depósitos, guardá-los e arquivá-los. (FREIRE, 1987, p. 33)

Em consequência ao tempo escasso das aulas, a educação no Ensino Remoto torna-se bancária, e o uso das plataformas digitais tornou-se um aliado em perspectiva. Sendo um ambiente de postagem de material didático e de atividades, em que os estudantes fazem a devolutiva daquilo que foi proposto; porém o retorno do professor além de não ser imediato, é efetuado sob nota numérica não havendo espaço e tempo para o desenvolvimento do processo/assimilação do aluno com a proposta, assim os estudantes passam a ser um depositário de conteúdos que não será digerido. Além disso, devido a desigualdade digital, uma 
parcela significativa, não possui nenhum tipo de acesso às aulas (via videoconferência), materiais didáticos e atividades que são disponibilizadas em plataformas digitais. Diante disso, como alternativa para estes estudantes, semanalmente, foIhas de atividades são disponibilizadas na escola, para serem retiradas de forma presencial.

A disposição das turmas no Ensino Remoto apresenta peculiaridades, pois ela é dividida em dois ambientes virtuais:

O primeiro diz respeito a plataforma digital Google Classroom, onde o material didático e atividades são disponibilizadas aos estudantes, sendo esta uma ferramenta utilizada de forma assíncrona, ocorrendo sem a necessidade de interação em tempo real entre estudantes e professor, assim, o conteúdo pode ser acompanhado em qualquer dia, hora e lugar. O segundo, consiste em plataformas de videoconferência, na qual ocorrem as aulas síncronas, onde acontece em tempo real.

No entanto, nem sempre os estudantes conseguem acompanhar os dois ambientes virtuais, ou seja, alguns participam apenas do Google Classroom (realizam as atividades), enquanto outros, participam apenas das aulas via videoconferência. Tal situação origina um descompasso no processo de aprendizagem, criando assim uma complexidade de situações, no qual temos que preparar mais de uma aula sobre o mesmo assunto, buscando abranger as diferentes realidades dos estudantes. Ocorre que acabamos ficando esgotadas e com muitas incertezas, pois não sabemos se todos estão sendo contemplados da mesma forma. Para sermos sinceras, acreditamos que não! Os alunos que acessam às plataformas digitais possuem mais privilégios no aprendizado, diferente dos demais, que apenas retiram o material impresso disponibilizado pela escola.

Por conseguinte, dentre os desafios educacionais que hoje perduram, também se relacionam com os desafios existentes no Ensino Presencial. Refletindo brevemente sobre o ensino das Artes, em si sofre com a desvalorização dentro das escolas, não sendo considerada uma disciplina importante/prioritária para a formação dos jovens e crianças, e no Ensino Remoto não foi diferente. As experimentações práticas, que no Ensino Presencial já eram difíceis de serem realiza- 
das, hoje no atual modelo, tornam-se quase impossíveis. Os estudantes muitas vezes não possuem nem o material básico como: lápis de cor, cola, tesoura, folha de ofício entre outros para realização das atividades. Materiais que antes eram fornecidos pelos próprios professores, como um ato solidário, pois a escola não possui condições de fornecer. Nesse caso, tentamos propor atividades com o uso de materiais alternativos como: papelão, jornal, garrafas pet, pigmentos naturais, entre tantos outros, como uma forma de contemplar a realização da prática.

O ensino passou a ser realizado quase que de maneira totalitária apenas na teoria. Sabemos da importância das experimentações, onde o aluno consegue aprender através da curiosidade, exercendo seu 'instinto' de pesquisador, indo em busca do desconhecido. Porém com a pandemia do COVID-19, como estagiárias tivemos que enfrentar esta dura situação de não saber como contemplar determinada competência.

Diante das constatações, percebemos que o nosso processo de formação vem sendo atravessado por situações que fogem do nosso controle. A pandemia do COVID-19, deixou em evidência o quanto precisamos pensar a educação como prioridade, com planejamento e acima de tudo respeito com os estudantes. Devemos pensar na especificidade de cada contexto que estamos inseridas. A experiência no Estágio Supervisionado nos tem deixado marcas profundas, onde a única certeza é a incerteza. Toda aula é uma situação diferente, seja por estudantes que adentraram a primeira vez na plataforma depois de meses de aula, ou aqueles que realizam as atividades impressas, que em um determinado momento entregam trabalhos com meses de atraso. É difícil e desafiador dar continuidade aos conteúdos e experimentações. Acreditamos que de certa forma, a nossa formação se tornará incompleta, por não termos o contato direto e contínuo com os estudantes. Ao mesmo tempo vivenciamos situações que nos fazem compreender os anseios e medos do 'ser professora', nos engrandecem e nos fazem refletir, sobre contextos, desigualdades e a importância das relações na educação. 


\section{CONSIDERAÇÕES FINAIS}

Diante dos fatos mencionados, percebemos que a educação em tempos de COVID-19, deixará marcas em uma geração inteira de crianças e adolescentes, estes que foram impedidos pelo sistema de continuar estudando. Temos a consciência que a Base Nacional Comum Curricular (2017), não está se fazendo cumprir no atual contexto que estamos vivenciando, pois esta não foi pensada para abranger as diversidades brasileiras em meio a situações de calamidades públicas.

Enquanto estagiárias e bolsistas do Programa Residência Pedagógica infelizmente, possuímos mais indagações do que conclusões exatas, pois não sabemos o futuro da educação. Entretanto, podemos afirmar que de alguma forma intentamos repensar o atual modelo de ensino que estamos inseridas. O Ensino Remoto na educação básica, jamais substituirá o Ensino Presencial, porém sabemos que diante da realidade que vivemos, talvez seja a única alternativa possível.

A pandemia deixou em evidência a diversidade de realidades educacionais existentes no nosso país, alguns continuaram os seus estudos 'normalmente', apenas adaptaram-se ao 'novo normal', outros, foram obrigados pelo sistema a abandonarem as escolas, pois faltam equipamentos, internet, acesso. Além de enfrentar a fome e a pobreza, são privados de seus direitos humanos fundamentais. Através do Estágio Supervisionado, vivenciamos fatos que ficaram marcados em nossa história como docentes em Artes Visuais, tentamos construir brechas para dar continuidade aos estudos. No entanto, diante do contexto atual, tendo como possibilidade o Ensino Remoto, entendemos a necessidade de buscar por alternativas para de algum modo continuar garantindo o ensino.

\section{REFERÊNCIAS}

BARRETO, Andreia Cristina Freitas; ROCHA, Daniele Santos. COVID-19 E EDUCAÇÃO: RESISTÊNCIAS, DESAFIOS E (IM)POSSIBILIDADES. Revista Encantar - Educação, Cultura e Sociedade, Bahia, n. 2, p. 1-11, jan./dez. 2012. 
BRASIL. Constituição (1988). Constituição da República Federativa do Brasil. Brasília, DF: Senado Federal: Centro Gráfico, 1988.

BRASIL. Lei 11.788, de 25 de setembro de 2008. Disponível em: http://www.planalto.gov.br/ccivil_03/_ato2007-2010/2008/lei/l11788.htm. Acesso em: 15 abr. 2021.

BRASIL. Ministério da Educação. Base Nacional Comum Curricular. Brasília, 2017.

GARCIA, F. Marta; RABELO, F. Dóris; SILVA, Dirceu; AMARAL, F. Sérgio. Novas competências docentes frente às tecnologias digitais interativas. Rev. Teoria e Prática da Educação, v. 14, n. 1, p. 79-87, jan./abr. 2011. Faculdade de Educação, Universidade Estadual de Campinas. Acesso em: 15 abr. 2021

GRANDISOLI, Edson; JACOBI, Pedro Roberto; MARCHINI, Silvio. Educação e pandemia: desafios e perspectivas. Jornal USP, 12 de ago. de 2020. Disponível em: https://jornal.usp.br/artigos/educacao-e-pandemia-desafios-e-perspectivas/. Acesso em: 15 abr. 2021.

São Paulo: Instituto Paulo Freire, 1968. FREIRE, Paulo. Pedagogia do oprimido. São Paulo: Paz e Terra, 1974. 


\section{$10.48209 / 978-65-89949-09-5$}

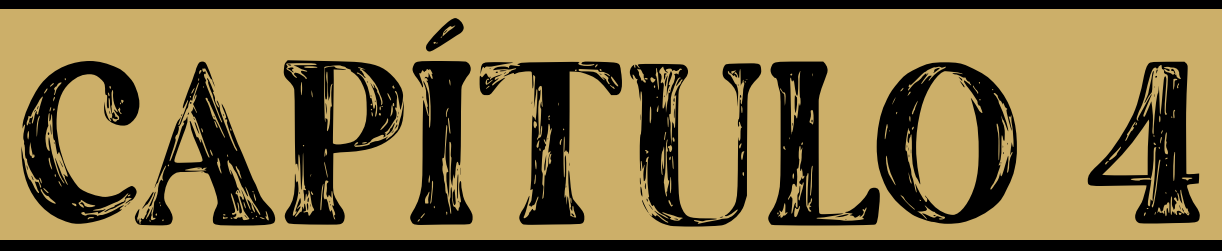

\section{A DANÇA E SUA RELAÇÃO COM A CULTURA E A EDUCAÇÃO}

Alexandra Aparecida dos Santos Noronha

Fernando Luiz Zanetti ${ }^{2}$

1 Mestranda em Educação e Formação Humana pela FaE/UEMG, Especialista em Dança e Consciência Corporal, Psicopedagoga, Pedagoga pela Universidade Estácio de Sá, bailarina internacional e coreógrafa, membro do CID-UNESCO.E-mail: alexandranoronha@hotmail.com

2 Doutor, mestre, bacharel, licenciado e formado em Psicologia pela Unesp de Assis. Fez pós-doutorado na Faculdade de Educação da Universidade de São Paulo - FEUSP. Atualmente é Professor da Universidade Estadual de Minas - UEMG. E-mail: fernando.zanetti@uemg.br 


\section{INTRODUÇÃO}

A dança compreende uma das manifestações culturais mais antigas do ser humano, antes de falar, o homem já dançava. A história da dança está associada à evolução cultural do homem: povos primitivos gesticulavam e, posteriormente, dançavam cultuando a natureza e os deuses, ou seja, antes de desenvolver a linguagem, o homem representava por gestos suas emoções, suas frustações, seus sentimentos e suas manifestações culturais. Desse modo, a dança é uma das grandes formas de expressão corporal, considerada por diversos historiadores uma das artes mais antigas.

O historiador Bourcier (2001) afirma que "[...] o primeiro documento que apresenta um humano indiscutivelmente em ação em dança tem 14.000 anos; o período histórico começa cerca de oito séculos antes da nossa era" (BOUCIER, 2001, p. 1-2). Nesse sentido, Vargas (1999) defende que "a dança e a expressão corporal nasceram junto com a humanidade, uma vez que se utilizavam os corpos para expressar ritmos, sentimentos e emoções" (VARGAS, 1999, p. 13).

Complementando essa perspectiva, um dos grandes estudiosos do movimento humano Rudolf Laban (1990) afirmou que a dança é a arte fundamental do homem:

[...] tanto que as demais artes deixaram testemunhos sob forma de edifícios, pinturas, manuscritos de poesias e de música, e a arte do movimento em épocas anteriores desvaneceu-se sem deixar mais vestígios que descrições acidentais em palavras [...] (LABAN, 1990, p. 11).

Por conseguinte, a dança por ser efêmera, tem seus registros mais antigos nas pinturas primitivas. Essas práticas mantiveram-se vivas nas danças populares, folclóricas, étnicas e nas danças gregas antigas passadas por gerações: "é difícil fazer um quadro de movimento ou coreografia"; diversos registros em dança se consolidaram com a criação da fotografia e principalmente do cinema, mas "o papel da arte na educação só foi redescoberta apenas em época recente" (LABAN, 1990, p. 11).

Este artigo busca abordar a relação entre dança, cultura e educação, ao discutir as pedagogias culturais sobre o ensino de dança no contexto escolar, a 
importância do ensino de dança, o multiculturalismo e a Base Nacional Comum Curricular (BNCC, 2018). Além disso, pretendemos averiguar como a pandemia do novo Coronavírus afetou a Educação e, principalmente, o ensino de dança nas escolas. Ao mesmo tempo, buscamos compreender os processos educativos em dança nas escolas públicas e sua ligação com a cultura e educação, bem como apresentar uma breve investigação sobre a "pedagogização do ensino da dança".

Desse modo, levantamos os seguintes questionamentos: Qual a relação entre dança e cultura? Existe uma pedagogização da dança no contexto escolar? A BNCC estabelece uma ligação entre o multiculturalismo e as danças populares brasileiras? Como a COVID-19 afetou o ensino de dança nas escolas?

A seguir, discutimos sobre dança e cultura, buscando tornar claras suas relações.

\section{DANÇA E CULTURA}

A dança é a cultura de um determinado povo e é uma de suas manifestações artísticas e culturais, ou seja, faz parte de sua tradição e de sua identidade. Percebemos diferenças nos ritmos, nos figurinos, nos gestos e nos passos de uma dança para outra, a exemplo das danças de origem africana e europeia. As danças de origem africana possuem ritmo mais forte e prevalência de instrumentos de percussão. Ademais, são sinuosas, sensuais e compostas por um leve gingado de quadril, dentre elas estão o samba, o forró, a salsa, a dança do ventre, etc. Já as danças de origem europeia, como o balé, o flamenco, o bolero e a valsa, são mais alongadas, quadradas e tem um ritmo mais suave, tendo em vista o uso de instrumentos de corda.

O Brasil é um país multicultural, marcado por influências de diversos povos, principalmente pelos indígenas, pelos portugueses e pelos africanos. Assim, temos danças e ritmos variados em todo país. Para Vargas (2009), "a dança sempre esteve, como em todas as culturas, presente na sociedade brasileira" (VARGAS, 2009, p. 32). Nesse sentido, "ao longo da história, o Brasil sofreu inúmeras influências de diferentes culturas, diferentes técnicas corporais e danças, construindo nessa diversidade seu caráter pessoal" (VARGAS, 2009, p. 34). 
Dessa forma, a cultura é tudo que representa o povo, sua identidade, seus hábitos, seus costumes e seu território. O autor Veiga-Neto (2003) relata que encontramos muitos entendimentos sobre o que seja "cultura" e, ao mesmo tempo, encontramos relações com a "educação". Nessa perspectiva, "a cultura foi durante muito tempo pensada como única e universal" e a educação era vista como forma de tornar-se mais culto (VEIGA-NETO, 2003, p. 7). Ainda, conforme o autor, "a cultura era entendida como conjunto de produções e representações que eram da ordem de saberes, de sensibilidade e de espírito" (VEIGA-NETO, 2003, p. 9).

Corroborando com essa temática, Costa et al (2003) comentam que a cultura:

[...] transmuta-se de um conceito impregnado de distinção, hierarquia e elitismos segregacionistas para um outro eixo de significados em que se abre um amplo leque de sentidos cambiantes e versáteis. Cultura deixa, gradativamente, de ser domínio exclusivo da erudição, da tradição literária e artística, de padrões estéticos elitizados e passa a contemplar, também, o gosto das multidões (COSTA et al, 2003, p. 36).

De acordo com a citação acima, a cultura estabelece uma ligação com a educação e a dança com a cultura e a educação. Desse modo, a dança é uma área de conhecimento, mas por que ela é tão negligenciada nos espaços escolares?

Os Estudos Culturais (EC) discutem as representações da educação nos discursos da tradição e da contemporaneidade. No Brasil, as extensões da pedagogia, do currículo, dos discursos da teoria e das disciplinas escolares trazem "a visibilidade de dispositivos disciplinares em ação na escola e fora dela; a ampliação e complexificação das discussões sobre identidade e diferença e sobre processos de subjetivação" (COSTA et al, 2003, p. 36).

Nesse sentido, a cultura e o currículo tornam-se um campo de luta na educação, ocasionando uma produção de poder - aspecto que é discutido nos trabalhos do filósofo Michael Foucault. Os EC têm estudado a positividade do poder para produzir novas subjetividades e identidades. Por isso, é fundamental o papel do docente para a produção de novas subjetividades (COSTA et al, 2003).

Ao problematizar o corpo no contexto escolar, percebe-se que ele é discipli- 
nado, domesticado. Para Foucault (1998), é no corpo que as relações de poder se constituem, ou melhor: "o poder encontra-se no próprio corpo" (FOUCAULT, 1998, p. 147). A dança, nas instituições escolares, segue metodologias tradicionais, surgindo, na maior parte das vezes, apenas em momentos de comemoração. Nesse viés, suas práticas pedagógicas são realizadas por repertórios prontos e repetitivos que serão apresentados em curto período, desconsiderando o aprendizado da dança, o conhecimento, a criatividade e a expressão corporal.

Na próxima seção, discutimos sobre Multiculturalismo, BNCC e ensino de dança.

\section{MULTICULTURALISMO: A BNCC E O ENSINO DE DANÇA}

Além de ser um conceito amplo, o multiculturalismo é "um termo que tem sido empregado com frequência, porém com diferentes significados" (CANEN, 2007, p. 92). Nessa perspectiva,

[é] importante assinalar que as diferenças entre as abordagens multiculturais [...] remetem, em última análise, a questões de fundo quanto: a) à forma como a identidade e a diferença são concebidas; b) à relação entre universalismo e relativismo na abordagem dada ao real c) à compreensão do multiculturalismo como campo de estudos de caráter híbrido (CANEN, 2007, p. 94).

Desse modo, o multiculturalismo considera as diferentes identidades, as pluralidades de raças, as religiões, os saberes, as culturas e as linguagens. A dança, sendo considerada uma forma de linguagem, conforme a BNCC, deverá ser integrada nas práticas pedagógicas. No contexto escolar, a dança tem a função de ampliar os horizontes, enfatizar identidades coletivas de gênero, raça, etnias, questões sociais, culturas diversas e quebrar paradigmas a partir, por exemplo, das danças urbanas (que vêm da cultura do Hip-Hop, popularmente conhecida como dança de rua), das danças populares brasileiras e das danças afro-brasileiras. Essas danças "estão diretamente relacionadas à pluralidade cultural, pois expressam conceitos e vivências de diferentes épocas e espaços geográficos" (MARQUES, 2012, p. 41).

Nessa lógica, o ensino de dança nas escolas contribui para aumentar as 
percepções culturais diversificadas, sensibilizar, problematizar e transformar as relações sociais. Conforme a BNCC (2018), "a Arte propicia a troca entre culturas e favorece o reconhecimento de semelhanças e diferenças entre elas" (BRASIL, 2018, p. 193).

Nessa continuidade, o documento aponta que o ensino de Arte proporciona conhecer novas culturas, reconhecer suas semelhanças e diferenças, estabelecendo um diálogo intercultural, relevante para o exercício da cidadania. A dança, portanto, conforme a BNCC, é constituída pela prática artística, por pensamentos e por sentimentos do corpo, bem como mediada pelos processos cognitivos e pelas experiências sentidas. Assim, os processos artísticos em dança são manifestados por meio do corpo e produzem um significado nas relações entre corporeidade e produção estética.

Canen (2007) ressalta que o professor deve construir perspectivas multiculturais "que valorizem as identidades, desafiem a construção dos estereótipos e recusem-se a congelar o 'outro'" (CANEN, 2007, p. 105). Portanto, além de ser uma prática artística, a dança envolve diversas características, como manifestações culturais, expressões de sentimentos e emoções; promove relações de corporeidade e produção estética; e, por fim, problematiza e transforma percepções corporais, culturais nos contextos que está inserida.

Isto posto, em seguida, problematizamos a "pedagogização" do ensino de dança em sala de aula.

\section{A DANÇA NO CONTEXTO ESCOLAR É ENSINADA DE FORMA "PEDAGOGIZADA"?}

A dança, sendo uma forma de expressão corporal da comunicação humana, sempre esteve presente nas manifestações cotidianas de povos antigos e continua a fazer parte da cultura de diversos povos. Entretanto, a dança no espaço escolar tem evidência, por vezes, somente nas festividades escolares e não é vista como objeto de conhecimento. Além disso, também encontramos muitas dificuldades para o ensino de dança nas escolas, no que concerne à infraestrutura, a dança não é objeto de conhecimento, encontramos práticas pedagógicas de dan- 
ça mecanizadas, ou seja, com repetições e cópias de coreografias direcionadas as festividades escolares.

De modo geral, a cultura escolar, os currículos e as práticas escolares padronizam as práticas humanas, pois estão associados às hegemonias de classes e aos interesses políticos. A escola, por vezes, ainda é bastante conservadora e adota metodologias tradicionais. Infelizmente, encontramos vários equívocos na maneira em que a dança é tratada no contexto escolar, como mostra Freitas (2019):

[...] somente como atividade de entretenimento, na busca de elaborar trabalhos coreográficos para apresentação em alguma data festiva, enfatizando apenas o seu caráter espetacular. Ao contrário desse modo de agir, ao se pensar a dança como um caminho possível de educação - ou mesmo de experimentação da vida - na escola, para muito além de se educar ou disciplinar um corpo, facilmente se pode descobrir a força transformadora que pode ter a utilização desta arte enquanto meio facilitador de processos de formação: processos de ensino/aprendizagem que visem a educação integral, o pleno desenvolvimento da pessoa em todos os seus domínios, do corporal ao sócio emocional (FREITAS, 2019, p. 300-301).

Assim, as práticas pedagógicas para o ensino devem considerar que o corpo se refere à própria pessoa, ou seja, dançar é ter maior conhecimento de si e do mundo. Assim, cabe ao docente desenvolver "possibilidades de interação entre os corpos e o mundo, por meio de processos de ensino e de aprendizagem que utilizem pensamentos e ações que realmente promovam uma educação integral" (FREITAS, 2019, p. 314).

Em lado oposto a essa perspectiva, podemos pensar em uma aprendizagem mecânica que nada mais é do que uma repetição sem fim de exercícios ou de sequências coreográficas, ou a cópia literal de uma coreografia. Essa prática torna o processo de ensino cansativo, engessado, sem produzir novos conhecimentos, sem refletir os processos educativos em dança em detrimento da criação de novos passos e movimentos corporais.

Por isso, "torna-se necessário olhar para o espaço pedagógico sob a perspectiva do professor, do aluno e das relações que, a partir deles, possam ser criadas" (RAMOS, 2018, p. 48). Temos que considerar que o ensino de dança compreende a aprendizagem técnica, mas também questões subjetivas, singula- 
ridades e diferenças entre as partes. Portanto, devemos estabelecer uma relação de "significação" entre o aprender e o ensinar.

Ainda com relação ao ensino de dança nas escolas, percebemos que ocorre uma possível prática de "pedagogização da dança". Essa pedagogização caracteriza-se na "[...] disseminação de enunciados oriundos de determinados campos do conhecimento (arte, filosofia, ciência etc.) para outros domínios da vida humana, com intuito de melhorar o homem ou educá-lo [...]". Dessa maneira, "como arte pedagogizada, a arte teria apenas valor como instrumento didático ou como melhoria ou adequação técnica dos indivíduos aos atuais modos de existência" (ZANETTI, 2018, p. 256-257).

Essas práticas de pedagogização fazem com que a dança seja um instrumento de ensino utilizado para fins psicológicos. Caracterizam-se também pela falta de reflexão sobre a dança e seu processo de ensino, ou seja, torna-se instrumentalizada ao realizar apenas a reprodução de coreografias, ao desconsiderar os processos criativos e as expressões dos alunos, bem como ao focalizar em apenas entretenimento durante apresentações artísticas escolares. A dança não está associada somente a emoções, mas também ao desenvolvimento da aprendizagem e da reflexão sobre as práticas artísticas.

\section{COMO A COVID-19 AFETOU O ENSINO DE DANÇA NAS ESCOLAS?}

O contexto da pandemia do novo Coronavírus afetou bastante a Educação, principalmente a educação pública, tendo em vista que inúmeros estudantes ficaram sem acesso ao conhecimento e à informação, devido à desigualdade social no Brasil. Em 2020, em quase todo o Brasil, as aulas presenciais foram suspensas e passaram a ocorrer de modo remoto, via Internet. No entanto, sabemos que muitos alunos não têm acesso às tecnologias digitais e os estudantes das classes menos favorecidas estão entre os mais prejudicados. Conforme a Organização das Nações Unidas para a Educação, a Ciência e a Cultura UNESCO (2020), a pandemia de COVID-19 aumentou as desigualdades educacionais na América Latina e no Caribe.

A área da educação sofreu muito com a pandemia. A UNESCO sinaliza que 
pelo menos $92 \%$ da comunidade escolar mundial teve suas aulas presenciais suspensas nos primeiros meses de pandemia. Cresceu o ensino a distância e o ensino remoto, mas para a população carente e para países menos desenvolvidos, o ensino a distância provoca mais desigualdades educacionais e sociais. Por outro lado, a pandemia ampliou a necessidade de fazer arte, dançar e movimentar o corpo. A dança fornece diversos benefícios ao corpo físico e ajuda a aliviar estresse, ansiedade e outras patologias.

Devido ao fechamento das escolas especializadas de dança durante a pandemia, a procura por aulas a distância aumentou em todo o mundo. $\mathrm{O}$ isolamento social trouxe vários fatores que levaram as pessoas a ter vontade de mover o corpo. Devido a isso, ocorreu uma virtualização da dança e surgiram festivais online, concursos, lives, entrevistas, cursos de formação, cursos para iniciantes em dança, danças virtuais e a dança através do aplicativo TikTok.

Para Mosé (2020), necessitamos de ter uma rotina para o isolamento e precisamos 'aprender a parar', um dos nossos maiores desafios. Além de aprendermos a lidar com as mudanças, com as instabilidades e com a solidão, precisamos gostar da nossa própria companhia para ter um relacionamento saudável com outras pessoas.

Durante a pandemia, o convívio familiar também foi intensificado, porque as pessoas passaram a ficar mais tempo em casa. Assim, os pais e os filhos e os casais têm maior convívio, o que pode gerar maiores conflitos entre os familiares. Mosé (2020) comenta que "vivíamos, mesmo com as pessoas mais íntimas, cada um em sua bolha, cada um acreditando que é o que imagina ser, e aplicando o mesmo raciocínio aos outros" (MOSÉ, 2020, p. 3).

No contexto escolar, o ensino remoto de Artes, nas suas linguagens música, artes visuais, teatro e dança, virou um grande desafio, pois o ensino já era precário. Como trabalhar o corpo, fazer atividades artísticas de forma remota? As atividades corporais estão sendo desenvolvidas?

Desse modo, vale ressaltar a "necessidade de aplicabilidade de práticas didático-pedagógicas na execução das aulas, com o intuito de transmitir um repasse de conteúdo de maneira harmoniosa e com vistas à produtividade por parte do 
interesse dos alunos" (PEDROSA, DIETZ, 2020, p. 110). Assim sendo, devemos refletir e adequar a formação docente para uma abordagem multidisciplinar, nesse contexto de pandemia, para que o corpo principalmente não fique inerte, e as outras linguagens artísticas sejam propostas (PEDROSA, DIETZ, 2020).

Laban (1990) defende que é fundamental o trabalho com o corpo, "uma das estruturas mais poderosas da estrutura corporal e mental é a arte do movimento" (LABAN, 1990, p. 14). A dança, 'a arte básica do homem', pode contribuir para a saúde mental e física das pessoas e traz outros diversos benefícios. Portanto, podemos afirmar que ela é muito importante também em um período de isolamento. Ademais, precisamos lembrar que trabalhar de forma multidisciplinar com danças populares brasileiras e danças urbanas é essencial para a continuidade do ensino de artes e para um ensino mais significativo para os alunos, levando em conta a multiculturalidade presente no Brasil.

\section{CONSIDERAÇÕES FINAIS}

As discussões apresentadas neste artigo apontam para a importância do ensino de dança no contexto escolar, afinal, a dança é uma das linguagens da Arte, considerada por historiadores uma das primeiras manifestações de linguagem humana e cultural. A dança é um elemento cultural muito importante, porque oferece aos seus praticantes muitos benefícios educacionais, sociais, psicológicos e científicos, além de ser um exercício que une corpo e mente, pois a dança é o 'pensamento do corpo'. Ela promove interação, amplia os horizontes culturais, trabalha coordenação motora, flexibilidade, melhora o ritmo e, no campo educacional, ajuda no desenvolvimento cognitivo, da criatividade, da imaginação, da percepção estética e do senso crítico.

Atualmente, a dança se tornou conteúdo obrigatório em toda educação básica. A LDB 13.278/16 e a BNCC (2018) definem que a dança seja uma das linguagens da Arte. Entretanto, os cursos superiores de Pedagogia, Artes e Educação Física têm lacunas em relação ao ensinar dança, o que afeta na prática escolar desses profissionais que, não raro, encontram muitas dificuldades e deixam a dança de lado. Quem está preparado para lecionar dança nas escolas o Licenciado em Dança ou o artista-docente? 
A pandemia trouxe uma necessidade de movimentar o corpo, mas também novos desafios para o ensino de dança. Os usos de redes sociais, mídias digitais em dança, as danças livres e populares têm sido mais utilizadas por profissionais de dança, mas no contexto escolar existe uma preocupação com o ensino de artes e dança? O corpo não deve ficar inerte, e a dança é uma grande potência que pode contribuir para a educação, desde que seja trabalhada de forma interdisciplinar, explorando culturas próximas dos alunos, como danças urbanas, brincadeiras antigas e jogos corporais individuais.

Outra questão importante é que muitas instituições escolares padronizam os corpos, a partir de uma abordagem tradicional e tecnicista, tentando discipliná-los e tornando a dança apenas um instrumento de entretenimento, que aparece nas festinhas com objetivo de fazer apresentações e não levar em consideração os processos educativos. As problematizações em dança sob a perspectiva de Foucault nos fazem refletir e questionar as práticas educacionais.

Ressaltamos que é essencial refletir sobre essas questões para que a dança não seja 'pedagogizada', por isso, "o fazer-sentir dança enquanto arte nos permite um tipo diferenciado de percepção, discriminação e crítica da dança, de suas relações conosco e com o mundo" (MARQUES, 2012, p. 27).

O ensino de dança contribui com questões de raça, etnia, gênero, identidade, religião e culturas diversas, ampliando o conhecimento dos docentes, quebrando normas pré-estabelecidas. Incluir danças urbanas, danças populares brasileiras e danças afro-brasileiras são pertinentes para compreender as diferenças multiculturais. Destacamos que as práticas corporais promovem questões multiculturais, pois encontramos linguagens, expressões e movimentos corporais diferenciados e corpos diferentes - este definido como um lugar de discurso e de luta.

Em suma, a dança além de ser uma prática artística, envolve diversas características, como manifestações culturais, expressões de sentimentos e emoções; promove relações de corporeidade e produção estética; problematiza e transforma percepções corporais, culturais nos mais variados contextos. Logo, a dança promove o reconhecimento e o respeito de culturas diversas, ou seja, o respeito à cultura e à identidade de um determinado povo, visto que essas manifestações culturais representam o povo, suas identidades, suas tradições e seus modos de viver. 
A capoeira e o samba são as principais danças brasileiras reconhecidas internacionalmente e consideradas nosso patrimônio cultural. O Brasil é muito rico culturalmente, porque possui uma grande extensão geográfica, por isso torna-se multicultural. Além disso, temos muitas danças populares e folclóricas originadas especialmente da junção das culturas indígenas, portuguesas e africanas, como forró, maracatu, frevo, baião, catira, carimbo, lundu, quadrilha, cirandas, festa do boi, dentre outras.

\section{REFERÊNCIAS}

BRASIL. Ministério da Educação. Base Nacional Comum Curricular. Brasília, 2018. Disponível em: <http://basenacionalcomum.mec.gov.br>. Acesso em: 03 mar. 2021.

BOURCIER, Paul. História da dança no ocidente. Tradução de Mariana Appenzeller.2. ed., São Paulo: Martins Fontes, 2001.

COSTA, Marisa Vorraber; SILVEIRA, Rosa Hessel; SOMMER, Luis Henrique. Estudos Culturais, educação e pedagogia. Revista Brasileira de Educação, n. 23, p. 36-61, maio/ago. 2003.

CANEN, Ana. O multiculturalismo e seus dilemas: implicações na educação. Comunicação \& política, v. 25, n. 2, p. 091-107, 2007.

FREITAS, Francisco Roberto de. A Dança na Educação Básica da rede pública municipal de ensino de Teresina/Piauí- uma realidade em crescimento. Revista da FUNDARTE, Montenegro, p. 298-315, ano 19, n. 37, jan./mar. de 2019. Disponível em: http://seer.fundarte.rs.gov.br/index.php/RevistadaFundarte/article/ view/654. Acesso em: 03 mar. 2021.

FOUCAULT, Michel. Poder-Corpo. In: FOUCAULT, Michel. Microfísica do Poder. RJ: Graal, 13. ed., 1998, p.145-152.

MARQUES, Isabel. Dançando na escola. 6. ed. São Paulo: Cortez, 2012.

MOSÉ, Viviane. O maior desafio do isolamento é aprender a parar. Disponível em: <http://navegacoesnasfronteirasdopensamento.blogspot.com/2020/04/viviane-mose-o-maior-desafio-do.html>. Acesso em: 03 mar. 2021. 
ORGANIZAÇÃO DAS NAÇÕES UNIDAS. Relatório da UNESCO mostra que a pandemia aumentou a desigualdade educacional na América Latina e no Caribe. Centro de imprensa, 09 de novembro de 2020. Disponível em: <https://brasil. un.org/pt-br/99885-relatorio-da-unesco-mostra-que-pandemia-aumentou-desigualdade-educacional-na-america-latina-e>. Acesso em: 03 mar. 2021.

PEDROSA, Gabriel Frazao Silva; DIETZ, Karin Gerlach. A prática de ensino de arte e educação física no contexto da pandemia da covid-19. Boletim de conjuntura, Boa Vista, p. 103-112, ano II, v. 2, n. 6, 2020. Disponível em: https://revista.ufrr.br/boca/article/view/PedrosaDietz. Acesso em: 03 mar. 2021.

RAMOS, Tarcísio dos Santos. A aprendizagem mecânica e a dança: tensões entre professor e aluno. PÓs: Revista do Programa de Pós-graduação em Artes da EBA/UFMG, v. 8, n. 16, nov. 2018. Disponível em: https://periodicos.ufmg.br/ index.php/revistapos/article/view/15600. Acesso em: 03 mar. 2021.

RUDOLF, Laban. Dança educativa moderna/ R. Laban; (tradução Maria da Conceição Parayba Campos). São Paulo: İCONE, 1990.

VARGAS, Lisete Arnizaut Machado de. Escola em dança: movimento, expressão e arte. Porto Alegre: Mediação, 2009.

VEIGA-NETO, Alfredo. Cultura, culturas e educação. Revista Brasileira de Educação, n. 23, p. 05-15, maio/ago., 2003.

ZANETTI, Fernando Luiz. O encontro da arte com a educação: O papel do saber psicológico. Educação em Revista, Belo Horizonte, n. 34, p. 255-275, 2018. 

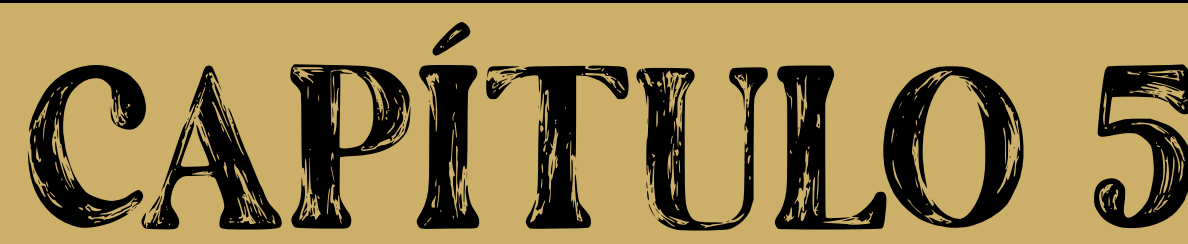

\title{
DANÇA EDUCATIVA MODERNA NA ESCOLA: ALGUMAS REFLEXÕES
}

\author{
Daniela Grieco Nascimento e Silva ${ }^{1}$ \\ Marcia Gonzalez Feijó ${ }^{2}$ \\ Tatiana Wonsik Recompenza Joseph ${ }^{3}$
}

1 Pós-Doutoranda em Gerontologia (UFSM); Doutora em Educação (UFSM); Diretora, Coreógrafa e Professora de Ballet da ONG Royale Escola de Dança e Integração Social - Santa Maria - RS; Professora de Ballet da UFSM Companhia de Dança. E-mail: daninasc21@gmail.com

2 Professora na Universidade Federal de Santa Maria (CEFD) no Curso de Dança Licenciatura; Cursos de Bacharelado e Licenciado em Educação Física; Doutora em Educação (UFSM); Certificada pela Polestar -Certiefeld Pratciitioner of Pilates Studio, como instrutora de Pilates; Professora de Pilates da UFSM Companhia de Dança. E-mail: marcgfa1@gmail.com

3 Professora do Curso de Dança Bacharelado da Universidade Federal de Santa Maria (UFSM). Doutora em Artes (UNICAMP), Pós-Doutorado em Estudos de Cultura Contemporânea pela UFMT (2012). Coordenadora da UFSM Companhia de Dança. Pós-Doutoranda na linha e pesquisa Práticas Investigativas da Cena: Poéticas, Estéticas e Pedagogias sob supervisão do prof. Dr. Marcílio Vieira de Souza, PPGArC, na UFRN.E-mail: twonsik@gmail.com 


\section{INTRODUÇÃO}

A inserção da dança na escola passa historicamente pelo desenvolvimento da dança moderna, uma vez que Rudolf Laban foi um dos primeiros pensadores a defender a importância da dança como expressão da subjetividade e de autoconhecimento das potencialidades do movimento, com suas diferentes qualidades e múltiplas possibilidades de combinação. A primeira edição do seu livro homônimo Dança Educativa Moderna é de 1948. Desde lá, pelo menos, já existe a idéia de que a dança não deve estar presente na escola como reprodução de movimentos codificados e rígidos, mas sim, como um processo de descoberta e experimentação, que não ignore a sensibilidade, a capacidade de (re) encontrar novos modos de ser, possibilitando que o professor de dança, possa permitir-se a tarefa de produzir arte com os alunos ou grupo de alunos (ICLE, 2012)

Neste sentido, é interessante contextualizar como o conhecimento artístico, enquanto área de estudo das Artes foi incluída no currículo escolar, nas escolas brasileiras em 1971, pela Lei de Diretrizes e Bases da Educação Nacional (LDB N5692/1971), sob o nome de Educação Artística, sendo considerada como uma "atividade educativa" e não como uma disciplina obrigatória. Dentre o conjunto das atividades artísticas, a área da dança foi a menos desenvolvida e incentivada em relação às demais.

Com a nova Lei de Diretrizes e Bases da Educação Nacional (LDB) No 9.394/1996, a Arte passou a ser considerada obrigatória na educação brasileira, passando a se constituir como componente curricular nos diversos níveis da Educação Básica, revogando a anterior, onde foi fundamental a contribuição das idéias de Ana Mae Barbosa (2010) tendo como premissa básica a integração do fazer artístico, a apreciação da obra de arte (fruição) e sua contextualização histórica, difundida pelas indicações da "Proposta Triangular para o Ensino da Arte", onde prevalecia o ensino das Artes Visuais.

Nesse seguimento, surgem os Parâmetros Curriculares Nacionais da Área de Arte de 1997/1998, revogando-se as disposições anteriores, então a arte é considerada disciplina obrigatória na educação básica. Assim, ampliaram-se o pensar artístico e a percepção estética, de modo que o aluno desenvolva seus modos 
próprios de sensibilidade, percepção e apreciação, produzidas por eles, pelos colegas, e nas diferentes culturas. Marques (2010) compreende como fundamental, as imbricações entre Arte e Educação, no sentido de aprofundar e ressignificar a dança como conhecimento na escola, partindo da experimentação de movimento como forma individual e coletiva.

A Base Nacional Comum Curricular (BNCC) é um documento, sistematizado em 2015, que regulamenta quais são as aprendizagens essenciais a serem trabalhadas nas escolas brasileiras públicas e particulares de Educação Infantil, Ensino Fundamental e Ensino Médio para garantir o direito à aprendizagem e o desenvolvimento pleno de todos os estudantes.

Constituindo-se num documento de caráter normativo, a BNCC (2015) define o conjunto orgânico e progressivo de aprendizagens essenciais que todos os alunos devem desenvolver ao longo das etapas e modalidades da Educação Básica. O documento foi criado para que todas as escolas tenham um padrão mínimo de instrução, e o esperado é que essa padronização aumente a qualidade do ensino no país, especialmente na esfera pública. A BNCC é dividida entre a base comum e a parte diversificada. O objetivo da segunda parte é enriquecer e complementar a parte comum. A idéia é inserir novos conteúdos aos currículos que estejam de acordo com as competências estabelecidas pela BNCC e também com a realidade local de cada escola. Portanto, o documento também é uma ferramenta para fundamentar a qualidade da educação ao estabelecer os níveis de desenvolvimento que todos os alunos têm o direito de acesso.

Em relação aos Parâmetros Curriculares Nacionais, a BNCC (2015) amplia as possibilidades de experiências com a Arte $^{19}$. Os PCNs trouxeram uma reflexão importante sobre o significado da Arte na educação e foram responsáveis pelo reconhecimento da Dança, da Música e do Teatro como linguagens que têm sua própria gama de conhecimentos específicos. A BNCC vai além e sugere caminhos para ampliar o acesso dos alunos a experiências estéticas nas aulas de Arte, colocando todas as crianças e jovens como protagonistas, que podem expressar seus sentimentos e sua criatividade por meio do processo artístico.

19 Embora a BNCC também coloque a dança como uma atividade da Educação Física, nesse texto a dança será analisada como componente da Arte. 
No Ensino Fundamental, o componente continua centrado nas linguagens das Artes Visuais, da Dança, da Música e do Teatro. Além dessas, uma última unidade temática, chamada de Artes Integradas, foi incorporada à BNCC, constituindo-se numa grande novidade. A proposta da integração das Artes é de que os alunos explorem as relações entre as diferentes linguagens e suas práticas, permitindo que em uma mesma proposta as corporalidades, visualidades, musicalidades, espacialidades e teatralidades estejam presentes de maneira concomitante. Além de articular as diferentes linguagens e suas práticas, possibilita também o uso das novas tecnologias de informação e comunicação.

Dentro de tal contexto, a dança na escola é uma atividade extracurricular importante. Ela tanto é um processo quanto uma ferramenta de aprendizagem que pode impulsionar o desenvolvimento integral dos estudantes de diferentes faixas etárias. A dança aperfeiçoa aspectos cognitivos, físicos, sociais e emocionais de crianças e adolescentes. O papel da dança na prática educativa tem o objetivo de resgatar, de forma natural e espontânea, as manifestações expressivas da nossa cultura. A expressão corporal como recurso da aprendizagem escolar, utiliza o corpo em movimento, estimulando a expressão de sentimentos e emoções que auxiliam na integração social, cultural e educacional.

Partindo desta concepção, o presente texto pretende refletir sobre o ensino, limites, e possibilidades da dança educativa moderna, compreendida aqui como Arte e Educação no espaço escolar na medida em que pretende ressignificar concepções de um corpo/sujeito sob o viés artístico-educativo.

\section{PRECURSORES DA DANÇA MODERNA}

A Dança Moderna surgiu entre o final do século XIX e início do século $X X$, refletindo as profundas transformações econômicas e sociais que o mundo vivenciava. Esses avanços técnicos e econômicos juntos com a progressão social e industrial contribuíram com o senso crítico e com diversos questionamentos que favoreceram estilos e linguagens próprias de diversos artistas na ascensão dessa nova linguagem, a chamada Dança Moderna.

De acordo com Maribel Portinari (1989), a Dança Moderna, assim como 
todo movimento artístico relevante, começa pela contestação, e, nesse caso, foi à rejeição do rigor acadêmico e dos artifícios do ballet.

Na verdade, a Dança Moderna surgiu como realização dos ideais do movimento romântico ${ }^{20}$. Indispôs-se de modo positivo contra a artificialidade do ballet clássico, estabelecendo como seu objetivo principal a expressão de um impulso interior, mas também reconheceu a necessidade de formas vitais desta expressão, e apreendeu o valor estético da forma, em si e por si mesma, como seu complemento. Ao levar adiante este propósito, desvencilhou-se de tudo quanto existia até então e recomeçou do início.

Este início foi a descoberta da verdadeira essência da dança: o movimento. Para Paul Bourcier (2006), este é um dos quatro grandes pontos básicos da dança moderna. Com esta descoberta, a dança tornou-se pela primeira vez uma arte independente, uma arte absoluta, circunscrita completamente em si mesma, relacionada diretamente com a vida, sujeita à variedade infinita.

Da mesma forma, o movimento é visto pelo bailarino moderno como uma entidade unificada, uma substância. Pode variar nas dimensões do espaço, intervalos de tempo, qualidade e intensidade, e ainda permanecer um elemento constante.

A fundamentação da Dança Moderna baseia-se, principalmente, nas influências norte-americana e alemã. Porém, o francês François Delsarte, que acreditou que os movimentos artísticos expressassem profundamente os sentimentos da alma humana, tornou-se um dos principais precursores desse movimento. Delsarte era um cantor que não sentiu o gosto do sucesso, pois perdeu a voz. Então, começou a refletir mais sobre suas experiências passadas e a relação entre a alma e o corpo, e as manifestações corporais que traduzem o que o corpo está sentindo interiormente. Seu trabalho começou com a catalogação de gestos e estados emocionais em cena, examinando diferentes casos patológicos, observando a manifestação de loucura e a dissecação de cadáveres.

20 O ballet clássico foi construído sobre formas arbitrárias, tradicionais e fixas. Os românticos do final do século XIX e início do século XX rebelaram-se contra o esteticismo frio deste sistema, substituindo todo o formalismo pela livre expressão pessoal da experiência emocional. Uma das maiores representantes do movimento romântico na dança foi Isadora Duncan. 
Aos poucos, constatou que a uma emoção, a uma imagem cerebral, corresponde a um movimento ou, ao menos, uma tentativa de movimento. Surgiu, então, a chave da dança moderna: a intensidade do sentimento comanda a intensidade do gesto. Delsarte subdividiu o corpo sistematizando o gesto e a expressão humana em três categorias: gestos excêntricos, concêntricos e normais, estabelecendo também três zonas de expressão: cabeça, tronco e membros.

De acordo com Maria da Graça Gonçalves (2009), a partir de suas observações e estudos, Delsarte concluiu que: todo o corpo é mobilizado para a expressão, principalmente o torso; que todos os dançarinos modernos, de todas as tendências consideram o torso a fonte e o motor do gesto; a expressão é obtida pela contração e relaxamento dos músculos: tension e release, que futuramente serão as palavras-chave do método de Martha Graham; a extensão do corpo está ligada ao sentimento de auto-realização, enquanto que o sentimento anulação se traduz por um dobrar do corpo. As idéias de François Delsarte foram passadas oralmente em suas conferências sendo somente sistematizadas após sua morte por um de seus discípulos Alfred Giraudet, em 1895.

Na Alemanha, Émile Jaques-Dalcroze (1865-1950), professor de música e pedagogo, idealizou e desenvolveu um método de sensibilização musical também foi chamado de "Eurritmia", muito referenciado nos trabalhos do campo da dança e da ginástica (PORTINARI, 1989). Dalcroze construiu um método de ensino musical que se baseava no aprendizado rítmico, buscando desenvolver nos alunos a espontaneidade e o domínio da performance musical por meio do aguçamento da cinestesia ${ }^{21}$ e da vontade musical, tendo a improvisação como um importante recurso didático.

Conhecido em português como Rítmica ou Eurritmia, o método de Dalcroze é formado por três pilares: o Movimento Rítmico, também chamado Rítmica ou Eurritmia; o Solfejo; e a Improvisação ao Piano. No Movimento Rítmico, Dalcroze buscava compreender e explorar a maneira como o corpo reage a estímulos rítmicos musicais e os interpreta. O movimento rítmico exerceu influência sobre a dança moderna. Foi utilizado como recurso criativo por dançarinos, performers

21 Sentido da percepção de movimento, peso, resistência e posição do corpo, provocado por estímulos do próprio organismo. 
e coreógrafos europeus atuantes na primeira metade do século XX. Artistas em formação se interessaram por seu método de aprendizado rítmico corporal e passaram a cursar aulas e programas dados por ele (BOURCIER, 2006). Muitos se formaram na escola de Dalcroze que funcionou em Hellerau. Apesar disso, Dalcroze se considerava estritamente um investigador da pedagogia e da performance musical. A fonte da música para ele eram os ritmos da natureza, incluindo os ritmos internos do corpo.

No arcabouço conceitual do movimento rítmico, muitos dos conceitos trabaIhados por Dalcroze, como o conceito matriz de cinestesia, o conjunto de conceitos da sequência cíclica preparação, ação e prolongação, e o conceito ação direta e ação imaginada, organizam procedimentos que atuam em prol do amplificar cinestésico do praticante. A exploração da harmonização corpomente foi o mais básico objetivo da prática rítmica corporal de Dalcroze. De modo que ele pode, por isso, ser considerado um dos precursores da educação somática ${ }^{22}$. Dentre os representantes da educação somática européia que tiveram crucial influência dalcrozeana, pode-se citar Gerda Alexander, a eurritmista criadora da Eutonia. Muitos dos pressupostos educacionais dalcrozeanos, como "a teoria deve seguir a prática" e "as regras só devem ser ensinadas quando o aluno viveu a experiência concernente a elas" são pressupostos educacionais dos métodos de educação somática hoje existentes. Esses métodos configuram atualmente uma linha da pedagogia da dança. Essa atualidade de idéias dalcrozeanas mostra a faceta precursora do pensamento de Dalcroze (DEL PICCHIA; PEREIRA; ROCHA, 2013).

Rudolf Von Laban e Mary Wigman foram alguns dos seus discípulos. Laban apropriou um sistema de linguagem humana voltada à movimentação: espaço, tempo, peso e fluência. Foi nesse sistema que a Dança Moderna encontrou suas principais características.

22 A Educação Somática é um campo teórico-prático composto de diferentes métodos cujo eixo de atuação é o movimento do corpo como via de prevenção ou de transformação de desequilíbrios de uma pessoa. Os métodos mais antigos foram se estruturando desde o início do século XX na Europa e na América do Norte. 


\section{A DANÇA EDUCATIVA MODERNA DE RUDOLF LABAN}

A Dança Educativa Moderna se estabelece a partir do pensamento moderno da Arte no Século XX, pelo artista, pesquisador e educador Rudolf Van Laban, que se dedicou aos estudos de sistematização da linguagem do movimento. Em seus estudos, Laban ressalta a riqueza das formas do movimento liberado nos gestos, nos passos, assim como naqueles movimentos da vida diária. É considerado junto com Mary Wigman e Martha Graham, um dos fundadores da Dança Moderna. Fez grandes danças corais (danças com um grupo grande de pessoas). No Brasil, seus ensinamentos foram introduzidos pela professora Maria Duschenes.

Laban fundamentalmente teorizou como acontece o movimento, e valeu- se da observação de movimentos corporais, ensinou que com seu corpo o sujeito adquiri conhecimento, e que não é possível separar conceitos abstratos, idéias e/ou pensamentos, da experiência corporal. Aponta múltiplas possibilidades e empregos dos movimentos no processo educativo, oferecendo movimentações menos restritas e mais criativas, de acordo com o desenvolvimento global do indivíduo, sejam crianças, adolescentes, jovens ou mesmo adultos (RENGEL, 2006).

A idéia básica de uma "nova dança" se dá por ações, relacionadas a qualquer atividade humana e, por conseguinte também na dança, que se apresentam por sucessões dos movimentos dos atos cotidianos para utilização dos movimentos corporais, do mais simples ao mais complexo. Tem como objetivos cultivar e concentrar o impulso inato das crianças ao realizar os movimentos, e fazer com que os grupos com mais idade tomem consciência dos princípios do movimento; preservar a espontaneidade do movimento a fim de perpetuá-lo até a vida adulta; fomentar a expressão artística a partir da criação, podendo se tornar uma dança coletiva.

Essas ações cotidianas se diferenciam no esforço específico, neste caso, o esforço é a expressão externa, a qual emerge de impulsos desejos, intenções, estados emocionais e pressões "internas". O impulso do movimento provém dos esforços internos, que são conduzidos para os espaços, tendo como ponto de partida a esfera espacial que rodeia o corpo, a Cinesfera. 
Elementos do esforço interno provém de como as pessoas se movem segundo os fatores de movimento: peso, espaço, tempo e fluência, que aprimoram a consciência corporal de diferentes esforços do movimento, valendo-se do fluxo do movimento. Os fatores do movimento e elemento do esforço são instâncias de um mesmo conceito. O elemento esforço é o conteúdo/forma ou effort/shape, ou seja, o contéudo "interno" que se torna visível, em forma. É importante esclarecer que não há hierarquia entre conteúdo e forma, escrevendo-se "conteúdoforma". Para Hengel (2006) deve-se entender/pensar/sentir o movimento como intelectual, físico, emocional, no sentido mais abrangente destes conceitos.

Assim as ações básicas do esforço representam a ordenação dentre as possíveis combinações das qualidades de fatores de movimento. Para tanto a Eukinética trata dos aspectos qualitativos, das dinâmicas e esforço imprimido no movimento. A Corêutica é a organização espacial que Laban (1990) desenvolveu, e o espaço corêutico é concebido pelo corpo, assim cada pessoa tem seu território próprio, sendo que esta não pode ser aplicada separadamente da Eukinética, as locações no espaço e as dinâmicas são partes de uma mesma realidade. Deste modo é importante esclarecer a importância da conscientização das influências entre a ação e os processos intelectuais e emocionais simultaneamente.

Ao construir uma minuciosa análise dos elementos de movimentos e suas combinações, no qual o corpo é concebido como uma totalidade complexa, produz ações, por meio de experimentos ou improvisações temáticas,em uma combinação das qualidades de movimento e fatores de movimento, que são nomeadas por oito ações básicas: torcer, pressionar, sacudir, cortar, socar, flutuar, deslizar e pontuar. Ações são guiadas por suas cinesferas (o máximo de limites que o corpo pode expandir-se e contrair-se), buscando manter o gestual e sua organicidade, a fim de ampliar o espaço cênico, utilizando-se de sua própria interpretação, de um corpo/sujeito de subjetivações e singularidades. Deste modo a idéia que a mente, opera separado do corpo, é rejeitada, pois o corpo se processa de maneira corponectiva, ou seja, a construção do pensamento só pode ser corporal, simplesmente porque "somos" corpo e não "temos" um corpo. 


\section{A DANÇA EDUCATIVA MODERNA NA ESCOLA}

Neste intento, os Parâmetros Currículos Nacionais (1997/1998), tem como subsídios os Temas Transversais (Ética, Saúde, Meio Ambiente, Orientação Sexual, Pluralidade Cultural) e os Referenciais Curriculares "Lição" RS (2009) a nível regional, por meio dos Temas Estruturantes (criação; apreciação; contextualização; elementos do movimento; relações em dança), que se apresentam em formato circular, evidenciando uma inter-relação e a ausência de hierarquia entre eles, tendo três competências transversais de todas as áreas, com os objetivos do ler, escrever e resolução de problemas. Já a BNCC sugere o trabalho artístico-educativo embasado nas Artes Integradas, possibilitando uma multiplicidade de ações interligadas.

Estes referenciais podem ser problematizados no corpo por meio de temas ou idéias, abstratos ou concretos. Destacamos um exemplo: Peça aos alunos que experimentem o dobrar, esticar e torcer os braços percebendo como isso ocorre no passo de Tesoura do Frevo, depois percebendo a movimentação das pernas e tronco. Solicitar como podem trabalhar essas movimentações no espaço e tempo, tendo como base a interpretação de um contexto das manifestações da referida dança brasileira, suas características e tradições culturais. Perguntar: O que podemos observar no corpo? Como se apresenta o corpo em relação a força da gravidade? Quais as possibilidades de temáticas a partir dessa manifestação cultural? Os alunos irão respondendo no corpo e pelo corpo, por meio de improvisação.

Este espaço aberto cria possibilidades de aproximar corpos, e multiplicar-se, contaminado por fontes culturais, artefatos, imagens, tendo como destino a 'hibridização' dos corpos na dança (Louppe, 2000); (Rocha,2012). O modo de pensar o aluno como corpo/sujeito dá a condição deste a assumir um papel de bailarino-intérprete ou intérprete-criador, autor de seu próprio processo de criação, tendo uma ação autoral sobre o seu fazer artístico. Esses processos de criação devem propiciar a escuta do corpo; utilizando as memórias corporais; lembranças; cotidiano da vida. Estas escutas facilitaram, a emersões individuais, que posteriormente podem ser compartilhadas em uma produção coletiva, onde a poética estará inscrita no corpo de cada aluno a cada construção de suas dramaturgias. 
Construir processos de criação demanda um tempo mais dilatado sobre cada estimulo ou temas solicitados, em contraposição, ao tempo de aula de arte, sobretudo, a dança, são de uma ou duas horas por semana, nos currículos formais, diferente das disciplinas de português, matemática, e outras tidas como mais 'importantes'. Não seria importante reivindicar às políticas públicas uma mudança de paradigma sobre a importância da arte, e da dança nos espaços educativos? Seria prudente então, permanecer com a mesma temática em maiores números de aulas, para que possamos na prática pedagógica explorar mais o processo do que o resultado da criação, para que este espaço de criação na dança se consolide aproximando saberes artísticos e os saberes pedagógicos, entrelaçando arte e docência, como explica Strazzaccappa e Morandi (2006), cabendo ao professor a função de artista-docente, ou seja, produzir criação compartilhada conjuntamente com o aluno, pois este, não deve abandonar suas possibilidades de criar, interpretar, dirigir, ampliando os processos artísticos, passando a ser revistos e repensados educacionalmente.

Dito isto, o fazer artístico no dançar desvela entrelugares, balizados pelas diferenças e, pelo difícil exercício de colocar-se no lugar do outro - podendo a arte do dançar fazer com seja um lugar de conhecer, questionar; transgredir, criticar, transformar, educar.

\section{ALGUMAS REFLEXÕES}

Isabel Marques (1999) aposta na dimensão educativa e artística da Dança na Escola ao entender a compreensão de professor como "artista-docente" que cria, dança e aprende com seus alunos/as. Entende que o conhecimento dos alunos é parcial e aberto, para tanto precisamos valorizá-lo no processo educativo, respeitando suas vivências anteriores e possibilitando críticas de ação, reflexão e crescimento como aluno-sujeito. Deste modo, a dança no espaço escolar deve propiciar uma vivência das diferenças, de corpos-sujeitos não idealizados, mas de corpos reais com alunos/as reais, criando diferentes possibilidades do dançar no espaço escolar.

Educar-se em dança necessariamente implica conhecer e apropriar-se cor- 
poralmente de suas estruturas formativas (sua 'sintaxe', sua linguagem) e não somente reproduzir seus estilos, códigos, passos, princípios anatômicos e cinesiológicos. O conhecimento da linguagem da dança, ou o que Laban chamou de "coreologia", possibilita um entendimento da dança que compreende a performance, a criação, a apreciação e suas relações com a sociedade (Marques, 2010).

Contemporaneamente, as propostas de Laban, se entendidas como linguagem, podem ter um papel primordial até mesmo na compreensão e execução das próprias técnicas codificadas, desconstruindo-as. Os estudos de Laban permitem a observação, análise e percepção corporal e intelectual dos elementos de movimento embutidos nos diferentes estilos de dança e, conseqüentemente, dos aspectos sócio-político-culturais dessa dança. Ou seja, ao estudarmos, vivenciarmos e compreendermos a linguagem da dança, compreenderemos também suas mensagens subliminares, pois a linguagem tem significação. Dessa forma, não mais faremos ingenuamente uma aula de balé, ou de dança moderna, ou de flamenco, mas teremos a possibilidade de ter uma maior consciência de como essas técnicas estão construindo nossos corpos e nos sugerindo que tipo de cidadania.

Nesta perspectiva, ao propor a Dança Educativa Moderna (Laban,1990), na escola faz-se necessário compreender o movimento para além da técnica, pois esta aponta possibilidades múltiplas do movimento no processo educativo, tendo o corpo na sua totalidade como ponto de partida para uma prática pedagógica.

\section{REFERÊNCIAS}

BARBOSA, Ane Mae. Abordagem triangular no ensino das artes e cultura visual. São Paulo: Cortez, 2010.

BOURCIER, Paul. História da dança no ocidente. São Paulo: Martins Fontes, 2006.

BRASIL. MINISTÉRIO DA EDUCAÇÃO. Base Nacional Comum Curricular. Brasília, 2015. Disponível em: <http://basenacionalcomum. mec.gov.br>. Acesso em: 28 de maio de 2021.

BRASIL. Senado Federal. Lei de Diretrizes e Bases da Educação Nacional: $\mathbf{n} .^{\circ}$. 5692. Brasília : 1971. 
BRASIL. Senado Federal. Lei de Diretrizes e Bases da Educação Nacional: $\mathbf{n}$ ․ $^{\text {. }}$ 9.394. Brasília : 1996.

BRASIL/ SECRETARIA DE EDUCAÇÃO FUNDAMENTAL. Parâmetros curriculares nacionais: arte. Brasília: MEC/SEF, 1997/1998.

DEL PICCHIA, Juliana Miranda Martins; PEREIRA, Denise Perdigão; ROCHA, Raimundo Andrade da. Émile jaques-dalcroze: fundamentos da rítmica e suas contribuições para a educação musical. IN: Revista Modus, Ano VIII, No 12, Belo Horizonte, Maio 2013, p. 73-88.

GONÇALVES, Maria da Graça G. Martha Graham: dança, corpo e comunicação. 114 f. Sorocaba: Universidade de Sorocaba. Dissertação, 2009.

ICLE, Gilberto. 0 que é Pedagogia da Arte? In: ICLE, Gilberto (Org.). Pedagogia da Arte Entre-Lugares da Escola. Porto Alegre: Editora da UFRGS, 2012.

LABAN, Rudolf. Dança educativa moderna. São Paulo: Ícone, 1990.

LOUPPE, Laurence. Corpos híbridos In: SOTER, Silvia; PEREIRA, Roberto (Org.). Lições de Dança 2. Rio de Janeiro: UniverCidade Editora, 2000

MARQUES, Isabel A. Ensino de dança hoje: Textos e contextos São Paulo. Cortez,1999.

MARQUES, Isabel A. Linguagem da Dança: Arte e Ensino. São Paulo: Digitexto, 2010.

MORANDI, C. $O$ ensino de Dança nas escolas: introdução In: STRAZZACAPPA, M.; MORANDI, C. Entre a arte e a docência: formação do artista da Dança. Campinas: Papirus, 2006.

PORTINARI, Maribel. História da dança. Rio de Janeiro: Nova Fronteira, 1989.

RENGEL, L. Dicionário Laban 3. Ed. São Paulo:AnnaBlume.2006

RIO GRANDE DO SUL. Secretaria de Estado da Educação. Departamento Pedagógico (org.). Referencial Curricular do Rio Grande do Sul - Lições do Rio Grande: Linguagens, Códigos e suas Tecnologias - Artes e Educação Física. Porto Alegre: Secretaria de Estado da Educação do Rio Grande do Sul, 2009

ROCHA, Thereza. Por uma docência artista com dança contemporânea in: GONÇALVES, Thaís; BRIONES, Héctor; PARRA, Denise; VIEIRA, Carolina (Org.). Docência-artista do artista-docente: Seminário Dança Teatro Educação. Fortaleza: Expressa Gráfica e Editora, 2012. 


\title{
$10.48209 / 978-65-89949-09-7$
}

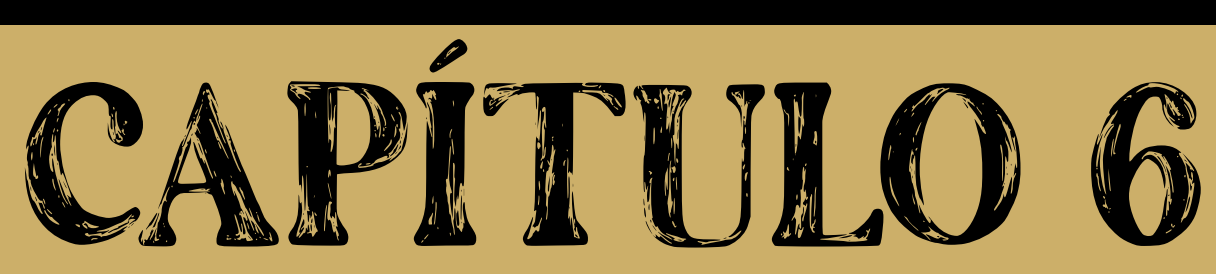

\section{DANÇANDO FAZERES E SABERES EM ARTE E EDUCAÇÃO: UM RELATO SOBRE A EXPERIÊNCIA DA ONG ROYALE ESCOLA DE DANÇA E INTEGRAÇÃO SOCIAL}

\author{
Daniela Grieco Nascimento e Silva ${ }^{1}$ \\ Marcia Gonzalez Feijó ${ }^{2}$
}

Tatiana Wonsik Recompenza Joseph ${ }^{3}$

\footnotetext{
1 Pós-Doutoranda em Gerontologia (UFSM); Doutora em Educação (UFSM); Diretora, Coreógrafa e Professora de Ballet da ONG Royale Escola de Dança e Integração Social - Santa Maria - RS; Professora de Ballet da UFSm Companhia de Dança. E-mail: daninasc21@gmail.com

2 Professora na Universidade Federal de Santa Maria (CEFD) no Curso de Dança Licenciatura; Cursos de Bacharelado e Licenciado em Educação Física. Doutora em Educação (UFSM). Certificada pela Polestar -Certiefeld Pratciitioner of Pilates Studio, como instrutora. Professora de Pilates da UFSM Companhia de Dança.E-mail: marcgfa1@gmail.com

3 Professora do Curso de Dança Bacharelado da Universidade Federal de Santa Maria (UFSM). Doutora em Artes (UNICAMP), Pós-Doutorado em Estudos de Cultura Contemporânea pela UFMT (2012). Coordenadora da UFSM Companhia de Dança. Pós-Doutoranda na linha e pesquisa Práticas Investigativas da Cena: Poéticas, Estéticas e Pedagogias sob supervisão do prof. Dr. Marcílio Vieira de Souza, PPGArC, na UFRN.E-mail: twonsik@gmail.com
} 


\section{INTRODUÇÃo}

O presente artigo objetiva apresentar e tecer reflexões sobre as ações artísticas e educativas desenvolvidas há 22 anos pela ONG Royale Escola de Dança e Integração Social, na cidade de Santa Maria - RS. Sua proposta artístico-educativa, que tem o ballet como núcleo central, centraliza-se nos princípios teóricos do educador brasileiro Paulo Freire, que sempre defendeu o foco do ensino como uma aprendizagem centrada no educando e no aprender, e não no educador e no ensinar. A partir daí criou a Pedagogia da Pergunta, e não da resposta. A Pedagogia da Pergunta institui uma aprendizagem mediada por questionamentos a partir dos quais é possível investigar um problema e encontrar soluções para tal, de modo que vá se desenvolvendo um pensamento ativo, criativo e crítico nos educandos.

Deste modo, o ensino do ballet proposto pela ONG Royale não é focado apenas no desempenho técnico e na glorificação de um determinado padrão corporal, mas na visão do corpo como expressão de uma subjetividade, cujas diferenças de padrões físicos e aprendizagens são respeitados e estimulados na singularidade de suas manifestações e interações. O ensino do ballet estabelece articulações com outras áreas do conhecimento, tornando o educando um sujeito cooperativo, participativo, reflexivo, sensível e criativo que possa ser um potencial agente de mudanças sociais, culturais e políticas.

\section{HISTÓRICO DA ONG ROYALE ESCOLA DE DANÇA E INTEGRAÇÃO SOCIAL}

Em 1996, a Royale, ainda como instituição privada, iniciou uma oficina gratuita de ballet para alunas da Escola Municipal Júlio do Canto, no Bairro Camobi, na cidade de Santa Maria - RS. Este trabalho encontrou grande receptividade na comunidade e extrema dedicação por parte das crianças. Então, a direção da Royale Academia de Ballet decidiu ampliá-lo. Em 1997, apresentou para a Prefeitura Municipal de Santa Maria um projeto, onde abria 40 vagas para as crianças das Escolas da Rede Municipal de Ensino. Esta experiência mudou totalmente o curso da finalidade da Royale Academia de Ballet. Auxiliada por um grupo de 
professores universitários e com o apoio de alguns cidadãos, que compreenderam e acreditaram na sua nova proposta, a Royale Academia de Ballet transformou-se, em 06/06/1998, na Royale Escola de Dança e Integração Social, uma entidade civil sem fins lucrativos. Sua missão passou a ser não apenas a de ensinar ballet, mas de tornar a arte e a educação agentes motivadoras no desenvolvimento das potencialidades e na inclusão social, cultural e educacional de crianças, adolescentes, jovens e suas famílias expostos a situações de vulnerabilidade na cidade de Santa Maria, Estado do Rio Grande do Sul.

De forma que, a Royale Escola de Dança e Integração Social, ciente das relações estruturais e conjecturais, as quais se inserem a criança e o adolescente, passou a contribuir para o sistema de garantia e defesa dos seus direitos, desenvolvendo ações artísticas e educativas preventivas as diversas situações de risco que as crianças, adolescentes e jovens encontram-se expostas em suas comunidades (evasão escolar, drogas, prostituição, violência, gravidez precoce).

É de acrescentar-se que, do paradigma de proteção integral às crianças e aos adolescentes no Brasil, à efetivação das políticas nacionais de ação, existe uma grande distância. A construção de um padrão-realidade perpassa necessariamente a um número cada vez maior de organizações que contribuem eficazmente para ampliar a mobilização nacional em defesa dos direitos das crianças e dos adolescentes. Então, a Royale Escola de Dança e Integração Social acredita estar colaborando neste sentido.

Atualmente, a Royale Escola de Dança e Integração Social é dirigida por uma Diretoria (Presidente, Vice-Presidente, Secretária, Tesoureira, Conselho Fiscal), eleita diretamente em Assembléia Geral de sócios colaboradores e comunidade beneficiada pelas suas ações. Também é eleita anualmente a Comissão de Pais de Alunos, que atua conjuntamente com a Direção e Coordenação de Projetos no planejamento, organização e efetivação das ações da Organização. Os projetos são coordenados pelos profissionais que atuam nos mesmos, em constante interação com a comunidade beneficiada, que avalia, de forma participativa, bimestralmente as ações. 
Nestes vinte e três anos de implementação de suas ações (Oficina Dança Cidadã, Oficina de Apoio Pedagógico, Oficina de Artes Visuais, Apoio Psicológico), a Royale e as pessoas envolvidas com a Organização tem compartilhado conhecimentos e ampliado às relações de troca e solidariedade no local e na comunidade. A reflexão contínua e o amadurecimento dos profissionais, do público atendido e do trabalho da Organização tem sido um processo diversificado e prazeroso. Nos últimos seis anos, a principal discussão tem sido a necessidade de ampliação das articulações e conexões entre pessoas/profissionais/instituições para o desenvolvimento das ações da Royale e seu conseqüente aperfeiçoamento e sustentabilidade.

A compreensão do trabalho da Royale integrando um universo mais complexo contribuiu de forma efetiva na busca de novas parcerias. Dentre estas se destacam: Prefeitura Municipal de Santa Maria, Universidade Franciscana, Universidade Federal de Santa Maria, Conselho Municipal da Criança e do Adolescente, Conselho Municipal de Assistência Social, Programa CVI Social, Rede Pontos de Cultura do RS, Rede Cultura Viva.

Nesses vinte e três anos de trabalho com crianças, adolescentes, jovens e famílias oriundas da periferia da cidade de Santa Maria-RS, a Royale orgulha-se de apresentar como resultados de seu trabalho: índice de $90 \%$ de aprovação escolar de seus educandos; inexistência de evasão escolar; inexistência de alunas com problemas de drogradição, prostituição, gravidez na adolescência; continuidade de estudos no Ensino Médio; presença de vinte educandos no Ensino Superior; formatura de dez educandas no Ensino Superior e suas inserções no mercado de trabalho e em cursos de pós-graduação; maior comprometimento das famílias no processo de educação de seus filhos, junto a suas comunidades e junto a Royale.

\section{METOdologia desenVOlVIdA PELA ONG ROYALE ESCOLA DE DANÇA E INTEGRAÇÃO SOCIAL}

A proposta artístico-educativa da ONG Royale Escola de Dança e Integração Social, que tem o ensino do ballet como eixo principal, centraliza-se nos princípios teóricos do educador brasileiro Paulo Freire, que sempre defendeu o foco 
do ensino como uma aprendizagem centrada no educando e no aprender, e não no educador e no ensinar. A partir daí criou a Pedagogia da Pergunta, e não da resposta. A Pedagogia da Pergunta institui uma aprendizagem mediada por questionamentos a partir dos quais é possível investigar um problema e encontrar soluções para tal, de modo que vá se desenvolvendo um pensamento ativo, criativo e crítico nos educandos.

Para Paulo Freire (1985), a educação não pode acontecer sem esse princípio e todo conhecimento começa pela pergunta e pela curiosidade. É na pergunta que está o interesse, ou a fome pelo conhecimento necessário para nutrir o pensamento na busca de significados. A pergunta desperta e conserva a curiosidade e a crítica e, nesse percurso, acaba melhorando consideravelmente a maneira de pensar, imaginar e criar como resultado do exercício de diferentes habilidades e competências.

Destarte, o ensino do ballet proposto pela ONG Royale não é focado apenas no desempenho técnico e na glorificação de um determinado padrão corporal, mas na visão do corpo como expressão de uma subjetividade, cujas diferenças de padrões físicos e aprendizagens são respeitados e estimulados na singularidade de suas manifestações e interações.

Portanto, a proposta da ONG Royale propicia que o ballet estabeleça articulações com outras áreas do conhecimento a fim de tornar o educando um sujeito cooperativo, participativo, reflexivo, sensível e criativo que possa ser um potencial agente de mudanças sociais, culturais e políticas, de acordo com a proposta de Valéria Maria Chaves de Figueiredo (2013):

A educação e a escola devem ser integrantes da totalidade social e não meras produções e/ou reproduções da cultura, e cabe à dança desenvolver metodologias, conteúdos e abordagens pedagógicas conectados com a diversidade das realidades sociais e a atualidade. Portanto, fica evidente a importância e a necessidade de um diálogo urgente, nos contextos educacionais, em prol do ensino de uma dança comprometida com a formação humana, de forma crítica e sensível, e que garanta aos alunos conhecer e vivenciar os aspectos das técnicas, das expressividades, percepções, sensibilidades, criatividade, a história, a memória, as novas tecnologias, as possibilidades interartísticas e as muitas interações que emergem do fazer artístico (FIGUEIREDO, 2013, p.87). 
Também são utilizados como embasamento teórico os quatro pilares da educação propostos pelo francês Jacques Delors que, além de trabalhar em conformidade com a teoria de Paulo Freire, aponta como principal conseqüência da sociedade do conhecimento a necessidade de uma aprendizagem ao longo de toda vida, fundamentada em quatro pilares, que são, concomitantemente, do conhecimento e da formação continuada. Os quatro pilares da educação propostos por Jacques Delors (1996) são os seguintes:

Aprender a conhecer - É necessário tornar prazeroso o ato de compreender, descobrir, construir e reconstruir o conhecimento para que não seja efêmero, para que se mantenha ao longo do tempo e para que valorize a curiosidade, a autonomia e a atenção permanentemente. É preciso também pensar o novo, reconstruir o velho e reinventar o pensar.

Aprender a fazer - Não basta preparar-se com cuidado para inserir-se no setor do trabalho. A rápida evolução por que passam as profissões pede que o indivíduo esteja apto a enfrentar novas situações de emprego e a trabalhar em equipe, desenvolvendo espírito cooperativo e de humildade na reelaboração conceitual e nas trocas, valores necessários ao trabalho coletivo. Ter iniciativa e intuição, gostar de um pouco de risco, saber comunicar-se e resolver conflitos e ser flexível. Aprender a fazer envolve uma série de técnicas a serem trabalhadas.

Aprender a conviver - No mundo atual, este é um importantíssimo aprendizado por ser valorizado quem aprende a viver com os outros, a compreendê-los, a desenvolver a percepção de interdependência, a administrar conflitos, a participar de projetos comuns, a ter prazer no esforço comum.

Aprender a ser - É importante desenvolver sensibilidade, sentido ético e estético, responsabilidade pessoal, pensamento autônomo e crítico, imaginação, criatividade, iniciativa e crescimento integral da pessoa em relação à inteligência. A aprendizagem precisa ser integral, não negligenciando nenhuma das potencialidades de cada indivíduo.

Uma educação fundamentada nos quatro pilares acima elencados sugere alguns procedimentos didáticos que the sejam condizentes, como: relacionar o 
tema com a experiência do educando e de outros sujeitos do contexto social; desenvolver a pedagogia da pergunta; proporcionar uma relação dialógica com o educando; envolver o educando num processo que conduz a resultados, conclusões ou compromissos com a prática; oferecer um processo de autoaprendizagem e corresponsabilidade no processo de aprendizagem; utilizar o jogo pedagógico com o princípio de construir o texto.

Outros pressupostos teóricos utilizados são os referentes à aquisição dos Códigos da Modernidade, propostos para a escola regular básica, apresentados por Bernardo Toro (1997): o domínio da leitura e da escrita; a capacidade de calcular e de resolver problemas; as condições de compreender e atuar em seu entorno social; a habilidade de escrever, interpretar e analisar fatos e situações; a capacidade de acessar informações; a capacidade de trabalhar em grupo.

Deste modo, são desenvolvidas ações interdisciplinares, onde o ensino do ballet constitui o núcleo central, articulado com as outras Oficinas que complementam e ampliam os processos artísticos e educativos, enfatizando o Estatuto da Criança e do Adolescente, os Direitos Humanos e as Políticas Públicas.

A Oficina Dança Cidadã constitui o eixo temático central da ONG Royale, envolvendo aulas de ballet com crianças de 6 a 11 anos de idade, adolescentes de 12 a 14 anos, jovens de 15 a 29 anos. A metodologia utilizada baseia-se no Método de Agripina Vaganova (Escola Russa de Ballet), juntamente com o Método Klauss Vianna para o ensino da dança clássica no Brasil. Além disso, os estudos pedagógicos de Paulo Freire e Isabel Marques dão suporte ao ensino da dança.

Deste modo, procura-se educar corpos livres de uma técnica dura e segmentada, mas capazes de perceberem e escutarem seus corpos num processo de aprendizagem criativo e reflexivo, com respeito ao próprio corpo e ao corpo do outro, resignificando o ser no mundo em forma de arte, já que:

No caso da dança, o fazer - sentir nunca está dissociado do corpo, que é a própria dança. Para que se possa compreender e desfrutar estética e artisticamente a dança, portanto, é necessário que nossos corpos estejam engajados de forma integrada com seu fazer - pensar. Essa é uma das grandes contribuições da dança para a educação do ser humano (MARQUES, 2010, p. 24). 
Cabe ressaltar que a técnica do ballet na ONG Royale é trabalhada com profundo respeito ao corpo do educando, respeitando seus limites e aprendizagens. Ou seja, seu limite de en dehors ${ }^{23}$ ou de flexibilidade aos poucos vão sendo aperfeiçoados, com calma e paciência, sem danos e traumas ao corpo do bailarino. Assim, o ballet dentro da metodologia da ONG Royale é ressignificado de acordo com o corpo de cada um e cada uma, dentro de um trabalho onde a coletividade é mais importante. Costuma-se dizer que na ONG Royale não existe uma primeira bailarina, pois todos são primeiros bailarinos, se revezando nos papéis de destaque dos espetáculos. O sentido do coletivo, da cooperação, da escuta, do diálogo, do respeito à opinião do outro são fatores fundamentais na formação das bailarinas e bailarinos da ONG Royale, onde:

O educando se reconhece conhecendo os objetos, descobrindo que é capaz de conhecer, assistindo à imersão dos significados em cujo processo se vai tornando também significador crítico. Mais do que ser educando por causa de uma razão qualquer, o educando precisa tornar-se educando por causa assumindo-se como sujeito cognoscente e não como incidência do discurso do educador. Nisto é que reside, em última análise, a grande importância política do ato de ensinar. Entre outros ângulos, este é que distingue uma educadora ou educador progressista de seu colega reacionário (FREIRE, 1992, p.47-48).

Assim, as turmas de ballet da Oficina Dança Cidadã são distribuídas em níveis, de acordo com a faixa etária dos educandos e os anos de estudo de ballet dos mesmos. Assim, a ONG Royale possui as seguintes turmas:

Preparatório $\rightarrow$ Nível de iniciação à técnica do ballet. As turmas envolvem crianças entre 6 e 11 anos de idade.

Intermediário $\rightarrow$ Nível de ballet que prepara o trabalho de iniciação ao uso da sapatilha de ponta ${ }^{24}$ e aperfeiçoamento da técnica clássica. As turmas envolvem adolescentes com 12, 13 e 14 anos de idade.

23 En dehors é uma expressão francesa que significa "para fora", constituindo-se na rotação externa do fêmur. A prática do en dehors é uma das principais características da dança clássica, sendo o fundamento básico sobre o qual se construiu a técnica do ballet. Basicamente é manter os calcanhares, joelho e coxas viradas para fora durante a execução dos movimentos da dança clássica.

24 As sapatilhas de pontas surgiram na Europa no século XIX com o intuito de proporcionar maior leveza para as bailarinas. Normalmente as estudantes de ballet iniciam seus trabalhos com sapatilhas de pontas em torno dos 12 anos, mas outros fatores devem ser levados em conta como o domínio da técnica do ballet, amplitude de movimentos nos tornozelos e maturidade física da bailarina. Cabe salientar que apenas as mulheres dançam com sapatilhas de pontas. 
Avançado $\rightarrow$ Nível de ballet cujo trabalho objetiva o constante aperfeiçoamento da técnica, envolvendo adolescentes e jovens entre 15 e 32 anos.

As turmas de Nível Preparatório têm aulas duas vezes por semana, com uma hora de duração. As turmas de Nível Intermediário têm aulas duas vezes por semana, com uma hora e trinta minutos de duração. A turma de Nível Avançado tem aulas três vezes por semana, com duas horas de duração. Todas as aulas são realizadas no turno inverso ao das escolas públicas e/ou cursos universitários freqüentados pelos educandos.

A Royale Companhia de Dança é constituída por 24 bailarinos, com idades entre 15 e 29 anos, que participam das aulas do Nível Avançado da ONG. Para esses educandos são realizados ensaios extras as sextas-feiras e aos sábados.

A Companhia de Dança foi formada em julho de 2004 a fim de incentivar as potencialidades artísticas dos educandos da ONG não apenas na dança, mas também na criação e execução dos espetáculos. Assim, os bailarinos participam da escolha do tema do espetáculo da Companhia, da criação e construção das cenografias, dos figurinos e da iluminação, numa linha de trabalho que possa levá-las a uma futura profissionalização.

Assim, a proposta da Oficina Dança Cidadã parte do pressuposto de que o movimento é uma forma de expressão e comunicação dos educandos, objetivando torná-los cidadãos críticos, participativos e responsáveis, capazes de expressarem-se em variadas linguagens, resgatando a autoestima e desenvolvendo a autoexpressão, o senso estético, a sensibilidade e fazendo-os pensar em termos de movimento.

Esta Oficina, ainda preocupada com a integração de seus educandos no mercado de trabalho, incentiva a partir do nível intermediário, uma qualificação para o trabalho docente em dança clássica. A metodologia baseia-se em aulas sobre a história, a técnica e a nomenclatura do ballet. São abordados outros temas como didática no ensino da dança clássica, noções de anatomia e psicologia do desenvolvimento, e ainda a apresentação de micro-aulas, trabalhos, pesquisa orientada e estágio supervisionado na ONG como educandos monitores. 
É a partir da Oficina Dança Cidadã que se organizam as demais Oficinas da ONG Royale, sendo as de Apoio Pedagógico e de Artes Visuais realizadas antes das aulas de ballet, nos dias em que os educandos freqüentam a ONG. As turmas são divididas por faixas etárias de acordo com a divisão dos níveis de ballet da Oficina Dança Cidadã.

A Oficina de Apoio Pedagógico é realizada uma vez por semana, com uma hora de duração, ministrada em turmas de níveis diferenciados. É centrada em técnicas de grupo - palestras, debates, estímulo à leitura e ao raciocínio lógico, produção de textos individuais e coletivos, encenações teatrais, construção de jogos, exposição de filmes educativos - usando como instrumentos o acervo da Biblioteca da ONG Royale e material oriundo das escolas regulares freqüentadas pelos educandos. Tais atividades propiciam aos educandos repensar seu entorno social e pessoal; expressar valores e crenças; fortalecer a autoestima, a autoconfiança, a autonomia, a participação democrática e exercício consciente da cidadania e também estudar criticamente o Tema Gerador do Espetáculo de Dança de Final de Ano Letivo da ONG Royale.

O Tema Gerador é baseado nos estudos de Paulo Freire (1977), para quem educar é um ato de conhecimento da realidade concreta, das situações vividas, um processo de aproximação crítica da própria realidade: compreender, refletir, criticar e agir são as ações pedagógicas pretendidas. Os temas geradores são, portanto, estratégias metodológicas de um processo de conscientização da realidade opressora vivida nas sociedades desiguais. São o ponto de partida para o processo de construção da descoberta, e, por emergir do saber popular, os temas geradores são extraídos da prática de vida dos educandos, substituindo os conteúdos tradicionais e buscados através da pesquisa do universo dos educandos.

caráter político da pedagogia freireana faz-se presente, de forma radical, nos temas geradores, isto é, temas geradores só são geradores de ação-reflexão-ação se forem carregados de conteúdos sociais e políticos com significado concreto para a vida dos educandos.

Portanto, no mês de outubro, todas as turmas da ONG Royale elegem o tema gerador do próximo ano, que será o tema do espetáculo de final de ano letivo seguinte. A partir de sugestões das turmas, são selecionadas três temáticas 
principais, que serão expostos e discutidos por todas as turmas. E, então, num dia estipulado, ocorre a votação direta, com direito a voto secreto na urna e apuração de votos. Já foram trabalhados como temas geradores: trabalho infantil, educação ambiental, obra de poetas e escritores brasileiros como Mário Quintana e Érico Veríssimo, obras de músicos como Chico Buarque, artistas como Frida Kahlo, livros como "Contando Histórias para Meninas Rebeldes".

A Oficina de Apoio Pedagógico também realiza aulas de reforço escolar, ministradas individualmente ou em grupos, com a utilização de jogos e materiais concretos, visando à recuperação de estudos para aqueles educandos que se encontram com baixo rendimento escolar. Cabe ressaltar que ocorre o acompanhamento da freqüência e do desempenho escolar dos educandos por meio da apresentação dos boletins/pareceres escolares e contatos com os setores pedagógicos das escolas públicas onde os mesmos estudam.

A Oficina de Artes Visuais é realizada uma vez por semana, com uma hora de duração, ministrada em turmas de níveis diferenciados. Os temas geradores escolhidos pelos educandos são preparados estimulando a livre expressão, com o objetivo de não perder o vínculo com a realidade social e aproximando os educandos do contexto cultural local, regional e nacional, enfatizando as contribuições populares na preservação da identidade cultural do povo brasileiro.

Os trabalhos desenvolvidos consideram situações vivenciadas e/ou conhecidas do cotidiano (notícias, passagens históricas, fatos da comunidade, da escola, do grupo, etc.), utilizando materiais e técnicas que desafiam os educandos a apresentar criações que fogem aos padrões preestabelecidos e, por isso passam a ser diferenciados, trazendo a marca da individualidade. Conforme a técnica utilizada, varia o nível de elaboração gráfica, sendo trabalhada a exploração tátil, a movimentação ampla, o preenchimento do espaço, a sobreposição, noção de frente e verso, organização de estruturas, junção de formas, orientação espacial, estruturação de formas, combinações de formas, jogo simbólico (significação das formas), entre outros.

A associação do lúdico às atividades visa estimular a criação, deixando a imaginação fluir e a execução da proposta realizar-se-á de forma natural, quase 
espontânea. Assim, a atividade plástica complementa e auxilia o educando na compreensão de conteúdos de outras áreas do conhecimento, transformando-se em instrumento pedagógico e auxiliando-o no fortalecimento de sua autoestima e de sua autonomia.

O Apoio Psicológico oferece atendimento psicológico individual e grupal às crianças, adolescentes, jovens e famílias participantes das ações da ONG Royale. Este atendimento tem caráter psicoterápico e de apoio-orientação, conforme as necessidades apresentadas por pais e educandos.

Os atendimentos individuais são realizados às sextas-feiras, tendo cinqüenta minutos de duração. Os pais com filhos em atendimentos individuais realizam encontros quinzenais com a psicóloga, com uma hora de duração, a fim de discutirem no grande grupo os problemas que os angustiam.

Os atendimentos grupais envolvem todas as turmas da ONG Royale e são realizados mensalmente, com uma hora de duração, pois considerando que os educandos serão os futuros multiplicadores da ONG, a intervenção psicológica oferece um espaço para a expressão e análise de experiências, onde possam trazer assuntos que lhes angustiam, discutir enquanto grupo, falar sobre suas dúvidas, seus medos, seus desejos e pensar alternativas para aprimorar o trabalho realizado pela ONG Royale. Através da escuta da grupalidade, compreende-se a multiplicidade de produções que o grupo é capaz de desenvolver e de buscar novas formas de pensar e agir.

Mensalmente, são realizados grupos de orientação, com uma hora e trinta minutos de duração, com os familiares dos alunos, onde se discutem temáticas como: importância da unidade familiar; direitos da criança e do adolescente; direitos do homem e do cidadão, prevenção contra as drogas; violência doméstica; sexualidade e outros. Cabe ressaltar que os temas são escolhidos pelos familiares.

\section{CONSIDERAÇÕES SOBRE A METODOLOGIA DA ONG ROYALE ES- COLA DE DANÇA E INTEGRAÇÃO SOCIAL}

Acredita-se que a metodologia desenvolvida pela ONG Royale Escola de Dança e Integração Social evidencia que aqueles que acreditam que a cultura é 
propriedade de uma elite privilegiada desconhecem o real valor da arte no processo educativo. Os Parâmetros Curriculares Nacionais (1997-1998), propostos pelo Ministério da Educação, colocam que a arte tem uma função tão importante quanto à dos outros conhecimentos no processo de ensino - aprendizagem, pois a verdadeira fecundidade da escola passa pela atividade sensível e criativa dos educandos.

Já a sistematização da Base Nacional Curricular Comum (2015) amplia as possibilidades de experiências com a Arte ${ }^{25}$, indo além dos PCNs. Deste modo, a BNCC aponta novos caminhos para ampliar o acesso dos alunos a experiências estéticas nas aulas de Arte, colocando todas as crianças e jovens como protagonistas, que podem expressar seus sentimentos e sua criatividade por meio do processo artístico.

No Ensino Fundamental, o componente continua centrado nas linguagens das Artes Visuais, da Dança, da Música e do Teatro. Além dessas, uma última unidade temática, chamada de Artes Integradas, foi incorporada à BNCC, constituindo-se numa grande novidade. A proposta da integração das Artes é de que os alunos explorem as relações entre as diferentes linguagens e suas práticas, permitindo que em uma mesma proposta as corporalidades, visualidades, musicalidades, espacialidades e teatralidades estejam presentes de maneira concomitante. Além de articular as diferentes linguagens e suas práticas, possibilita também o uso das novas tecnologias de informação e comunicação.

Baseada em tais pressupostos, metodologia utilizada pela ONG Royale salienta que, tanto em arte como em educação, não existem habilidades inatas, mas produtos de origem cultural, sendo necessário dar ao educando os instrumentos necessários para sua autoexpressão. Estas ideias estão de acordo com as considerações expressas por Carlos Roberto Modinger, quando coloca que a arte "é fundamental, tanto para a compreensão de nossa trajetória no mundo da riqueza cultural acumulada - que temos o dever de preservar - quanto para a produção de novas manifestações culturais, que precisamos incentivar" (MODINGER, et all, 2012, p. 41).

25 Embora a BNCC também coloque a dança como uma atividade da Educação Física, nesse texto a dança será analisada como componente da Arte. 
O direito à educação, conforme Jaime Pinsky (2008) está inserido junto aos direitos sociais, garantindo que os indivíduos possam se apropriar e usufruir das riquezas culturais da humanidade, incluindo-se na sociedade. O discurso da cultura predominante sobre o papel da escolarização procura excluir as classes populares do processo de ensino - aprendizagem, transformando a educação num instrumento de controle do conhecimento, objetivando garantir a manutenção do seu poder político e econômico.

Para isto, a classe dominante prevalecente impõe seu poder cultural sobre as classes populares, desvalorizando seus saberes e pregando que os mesmos são "incapazes" de elaborarem e usufruírem saberes culturalmente impostos, alienando-os de sua cidadania. Destarte, acaba ficando de fora desse processo, a intensa e complexa trama de relação estabelecida por cada um, suas histórias de vida, suas formas de lidar com o conhecimento, como a própria contextualização da realidade, estabelecida de maneira a explorar conjuntamente aspectos cognitivos, sociais e psíquicos de educadores, educandos e espaço escolar na construção do processo de ensino - aprendizagem, pois:

O aluno aprende quando, de alguma forma, o conhecimento se torna significativo para ele, ou seja, quando estabelece relações substantivas e não arbitrárias entre o que se aprende e o que já conhece. É um processo de construção de significados, mediado por sua percepção sobre a escola, o professor e sua atuação, por suas expectativas, pelos conhecimentos prévios que já possui. A aprendizagem implica, assim, estabelecer um diálogo entre o conhecimento a ser ensinado e a cultura de origem do aluno (DAYRELL, 1996, p. 156).

Ao não tocar significativamente o educando, o conhecimento não tem voz, desmembra-se, ficando totalmente desvinculado do corpo do sujeito. E educadores e educandos não conseguem encaixar o amplo quebra cabeça do saber, não o contextualizam, perdendo-se nas peças sem sentido. Origina-se um corpo sem intencionalidade, que articula um discurso catatônico, de mera repetição e reprodução.

Alicia Fernández (1994, p. 74) diz que "para que haja aprendizagem, intervém o nível cognitivo e o desejante, além do organismo e do corpo". Ou seja, aprender não se relaciona apenas ao nível cognitivo, engloba o sujeito como um todo, onde o psíquico e o organismo também interagem para edificar o conhecimento. 
Mas, sabe-se que a escola regular além de não conceber o corpo como construtor ativo de conhecimento, ainda o aprisiona como mero "carregador" alienado do saber, constituindo-o num objeto sem participação. Na ONG Royale o corpo dos educandos constitui-se em sujeito ativo no processo de aprendizagem, incorporando o saber não apenas por meio de práticas corporais, mas também no desenvolvimento de novas posturas e comportamentos. O corpo aprende ao andar, ao ver, ao ouvir, ao falar, ao cheirar, ao comer. O corpo, de acordo com Paulo Freire (1985), aprende por meio da cotidianeidade, sensibilizando a si e aos outros, construindo e reconstruindo o sujeito e o mundo, por meio das ações do indivíduo sobre o entorno. Aprender, então, constitui-se praticamente em sinônimo de viver, pois o corpo exprime seus desejos, seus sentimentos, suas perguntas, recriando-se constantemente como agente do conhecimento.

O corpo humano, velho ou moço, gordo ou magro, não importa de que cor, o corpo consciente, que olha as estrelas, é o corpo que escreve, é o corpo que fala, é o corpo que luta, é o corpo que ama, que odeia, é o corpo que sofre, é o corpo que morre, é o corpo que vive. Não foi rara a vez em que pondo minha mão afetivamente no ombro de alguém, tive-a, de repente, no ar, enquanto curvando-se, o corpo tocado recusava o contato do meu (FREIRE, 1985, p.28)

Assim, o ensino do ballet, tal como desenvolvido pela ONG Royale, traz consigo a disciplina, a dedicação, a persistência, a postura, os valores necessários não apenas para o pleno desenvolvimento da arte, mas também da própria vida, levando em conta "o aluno em sua totalidade, retomando a questão do aluno como um sujeito sócio-cultural, quando sua cultura, seus sentimentos, seu corpo, são mediadores no processo de ensino e aprendizagem" (DAYRELL, 1996, p. 157).

$\mathrm{Na}$ ONG Royale, o educando aprende a ser no encontro consigo mesmo nas aulas de ballet, onde sua autoestima, sua autoconfiança, sua autodisciplina são trabalhadas. Aprende a respeitar as limitações do próprio corpo, vendo o mesmo como extensão de sua própria personalidade. Também aprende a conviver com suas colegas, a respeitar os outros, a escutar, a dialogar, vendo-se como parte integrante de um grupo onde existem direitos e deveres para cada um. Aprende a fazer e a conhecer ao contextualizar o Tema Gerador dos espetáculos de dança e ao tornar-se um multiplicador da metodologia da ONG Royale em sua comunidade. 
O corpodançante dos bailarinos da ONG Royale tornam-se sensíveis ao próprio processo educativo, sentindo a aprendizagem interligada em todas as demais Oficinas da ONG. Então, começam a desenvolver e a aprimorar suas competências na leitura, na escrita, nas artes visuais, pois percebem que são capazes de aprender, capazes de realizar, que possuem muitos e inúmeros talentos que podem e devem ser desenvolvidos.

Aqueles educandos que encontram-se em defasagem escolar também são capazes de transcender o estereótipo do não-aprender, pois a dança Ihes proporciona uma nova visão de si mesmos, com mais autoconfiança, com mais autoestima. Deste modo, o trabalho do Reforço Escolar encontra um solo mais fértil para germinar.

Os familiares dos educandos, ao sentirem a mudança que ocorrem na vida de seus filhos, acabam sensibilizando-se pelas ações da ONG Royale e integrando-se nos grupos de orientação psicológica. Então, os familiares também aprendem a ser, a fazer, a conviver e a conhecer, construindo novas perspectivas a suas vidas.

Ao trabalhar uma educação para a transformação, a ONG Royale propicia que seus educandos tenham a oportunidade de vivenciar concretamente valores como à vida, a solidariedade, o diálogo, a cooperação, a justiça, a igualdade, a participação, de maneira que os mesmos os incorporam em si mesmos, multiplicando-os em suas vivências pessoais, sociais e comunitárias e iniciando processos transformadores na sociedade.

Gostaríamos de ressaltar que as ações da ONG Royale, que tem o ballet como núcleo principal, sustentam-se numa forte base interdisciplinar. Ou seja, as transformações ocasionadas são oriundas de um trabalho artístico e educativo com forte embasamento político de emancipação, onde todos os envolvidos estão comprometidos com tal processo. De modo, que não podemos afirmar que apenas o ensino do ballet poderia desencadear tal desenvolvimento.

Ao finalizarmos essa escrita, gostaríamos de colocar que consideramos a ONG Royale Escola de Dança e Integração Social um espaço de esperança, de informações, de diálogos, de questionamentos, de ações, de criações e de trans-

\section{CAPÍTULO 6}

SILVA, D. G. N. e; FEIJÓ, M. G.; JOSEPH, T. W. R. DANÇANDO FAZERES E SABERES EM ARTE E EDUCAÇÃO: UM RELATO SOBRE A EXPERIÊNCIA DA ONG ROYALE ESCOLA DE DANÇA E INTEGRAÇÃO SOCIAL. 
formações, onde o sujeito tece, com movimentos lúdicos, a trama de conhecimentos que sustenta sua vida e que irá, consequentemente, ocasionar transformações na sociedade.

\section{REFERÊNCIAS}

BRASIL. MINISTÉRIO DA EDUCAÇÃO. Base Nacional Comum Curricular. Brasília, 2015. Disponível em: <http://basenacionalcomum. mec.gov.br>. Acesso em: 28 de maio de 2021.

BRASIL/ SECRETARIA DE EDUCAÇÃO FUNDAMENTAL. Parâmetros curriculares nacionais: arte. Brasília: MEC/SEF, 1997/1998.

DAYRELL, Juarez. A escola como espaço sócio-cultural. In: Múltiplos olhares sobre educação e cultura. Belo Horizonte: Editora UFMG, 1996.

DELORS, Jacques. Educação: um tesouro a descobrir. Relatório para a UNESCO da Comissão Internacional sobre a Educação para o século XXI. Rio Tinto: Asa, 1996.

FERNÁNDEZ, Alícia. A mulher escondida na professora: uma leitura psicopedagógica do ser mulher, da corporeidade e da aprendizagem. Porto Alegre: Artes Médicas, 1994.

FIGUEIREDO, Valéria Maria Chaves de. A dança, a escola e seus diferentes espaços e tempos. IN: Dança, Salvador, v. 2, n. 2, p. 81-92, jul./dez. 2013.

FREIRE, Paulo. Pedagogia da esperança: um reencontro com a pedagogia do oprimido. Rio de Janeiro: Paz e Terra, 1992.

. Pedagogia do oprimido. Rio de Janeiro: Paz e Terra, 1977.

. Por uma pedagogia da pergunta. Rio de Janeiro: Paz e Terra,

1985.

MARQUES, Isabel A. Dançando na escola. São Paulo: Cortez, 2010.

MELUCCI, Alberto. O jogo do eu: a mudança de si em uma sociedade global. São Leopoldo: Ed. Unisinos, 2004. 
MODINGER, Carlos Roberto; et all. Artes visuais, dança, música e teatro: práticas pedagógicas e colaborações docentes. Erechim: Edelbra, 2012.

PINSKY, Jaime. História da cidadania. São Paulo: Contexto, 2008.

TORO, Bernardo. Códigos da modernidade: capacidades e competências mínimas para participação produtiva no século XIX. 1997. Disponível em <http://www. modusfaciendi.com.br.>Acesso em 06/04/2021. 


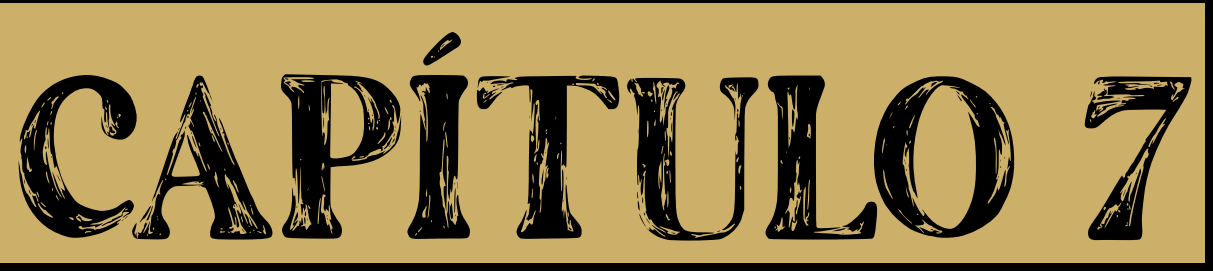

\section{ENSINO COLETIVO DE INSTRUMENTO: A METODOLOGIA USADA EM UMA COMUNIDADE DE GOVERNADOR VALADARES/MG}

Alex de Paula ${ }^{1}$ 


\section{INTRODUÇÃo}

Essa pesquisa aborda o ensino coletivo de instrumento realizado em uma comunidade da cidade de Governador Valadares/MG. Nela poderá ser identificada a metodologia usada em uma classe de ensino de instrumento na cidade de Governador Valadares/MG onde foi realizada essa pesquisa. A metodologia da pesquisa terá uma abordagem qualitativa.

Com poucas informações a respeito sobre o ensino coletivo de instrumento na cidade, estes estudos feitos nessa pesquisa serão úteis para estudos relacionados ao ensino coletivo de instrumento para que possa contribuir para pesquisas cientificas dos interessados no assunto. Tem a finalidade em conhecer os aspectos da metodologia usada no ensino coletivo de instrumento, essa pesquisa busca conhecer o aprendizado dos alunos, refletir o porque de ensinar coletivamente, descrever sobre o ensino coletivo de instrumento, contextuar as concepções do docente sobre o ensino coletivo e conhecer os materiais didáticos usados pelo professor pesquisado no ensino coletivo.

Essa pesquisa terá uma abordagem qualitativa, uma abordagem que privilegia o nível subjetivo e interpretativo da pesquisa, tendo em vista assim uma meIhor interpretação e entendimento do pesquisado Freire (2010). O objetivo principal da pesquisa qualitativa é entender com clareza a condição humana, Bogdane Biklen (1994).

Tendo como meta da pesquisa identificar a metodologia usada no ensino coletivo do instrumento em uma comunidade de Governador Valadares/MG, a pesquisa será de caráter descritivo e abordará a descrição da característica de um grupo, Gil (2010).

\section{DESENVOLVIMENTO}

A música popular com toda sua variedade de gêneros vem sendo conhecida e incorporada por docentes de música, conferencistas e professores de instrumento que lecionam do ensino primário ao universitário, Green (2002).

Neste trabalho iremos destacar as práticas de um professor da escola 
municipal da cidade. Em outros ambientes o professor atua com o ensino do instrumento, nos projetos sociais e aulas particulares trabalha com o ensino coletivo de instrumento. Aulas particulares ${ }^{26}$ de variados instrumentos. Tendo como base que o professor deve obedecer aos interesses e vontades dos alunos do ensino coletivo do instrumento. (CRUVINEL, 2005).

Um dos locais de atuações do professor é uma escola municipal. A escola atende 455 alunos da comunidade, tendo 35 professores ativos e 77 funcionários. Oferece a educação desde o pré-primário até a oitava série - ensino fundamental. São alunos entre 6 a 14 anos de idade e o nível sócio econômico dos alunos são baixo.

A escola possui alguns pandeiros, tambores e alguns instrumentos de percussão confeccionados pelos próprios alunos. O professor leciona fazendo uso de seus próprios instrumentos. As características dos alunos são participantes frequentes das aulas de música, são turmas que não tem um conhecimento aprofundado na área da música. São alunos de baixa renda salarial, onde um número considerável de alunos vivem em situações bem precárias.

O professor também desenvolve trabalhos musicais em projetos sociais. Este trabalho social tem o apoio da "Igreja São Paulo", ela sede as salas para que os fiéis que tenham interesse em aprender um instrumento, possam fazer aulas em suas dependências. A igreja está situada na rua, Hidelbrando Cabral - 201, bairro São Paulo. A igreja contém um templo onde os fieis se reúnem para adoração, ao lado da igreja possui salas amplas com cadeiras e nestas salas é onde são ministradas as aulas de catecismo e outros cursos. Nestas salas também é ministradas aulas de violão para alunos que tenham interesse em aprender a tocar o instrumento. São alunos de idade variadas e o nível sócio econômico dos alunos é baixo.

A igreja apoia o ensino da música para jovens e adolescentes e incentiva-os a aprender música para apresentar nos trabalhos da igreja. A instituição possui salas amplas, bem iluminadas e ventiladas. Possui quadros para que o docente possa fazer uso. O docente que atua nesse local, é o entrevistado desta pesquisa.

26 Aula particular é que não há interseção entre o professor e aluno, que entram num acordo a respeito do local, do conteúdo, carga horaria e preço Requião (2001). 
Nesse estabelecimento são aulas de ensino coletivo de instrumento, o professor ensina a tocar o instrumento violão, e nessas aulas do ensino do instrumento, cada aluno possui seu próprio instrumento.

\section{O ensino coletivo}

Existem dois modelos de ensino coletivo, o homogêneo quando é lecionado em grupo o mesmo instrumento e o heterogêneo quando é lecionado em grupo vários instrumentos. Cruvinel (2005).

O ensino coletivo é uma pratica pedagógica aplicada a vários instrumentos musicais e que vem alcançando grande desenvolvimento pedagógico, aplicado ao ensino instrumental em fases iniciais, Issacaba (2010).

Issicaba (2010) são vantagens o autor destaca do ensino coletivo ou trabalho em grupo feito por alunos: "a interação entre os alunos, o ambiente lúdico criado por esta interação, que resultam na socialização, cooperação e motivação, promovendo o desenvolvimento da afinação e do ouvido harmônico" (Issicaba 2010). Destaca também que o repertorio num grupo acontece mais rapidamente, com os alunos conseguindo ler e executar a música em menos tempo do que em aulas individuais com repertorio solo.

Sobre o tempo da utilização da metodologia do ensino coletivo, esse pensamento em relação ao tem pó do ensino coletivo deveria ser usado apenas para iniciantes, no qual o aluno, após um período nessa metodologia, deveria prosseguir seus estudos com aulas individuais. Issicaba (2010).

Pizzato e Hentschke declaram que as expectativas e os valores, interesse, importância, utilidade e custo da tarefa, influenciam diretamente o desempenho e escolhas de tarefas a serem realizadas (Pizzato; Hentschke, 2010, p. 41).

Como pontos negativos no ensino coletivo do instrumento Issicaba (2010), destaca a não uniformidade do grupo, o tempo do uso da metodologia e os encontros periódicos. 


\section{FORMAÇÃO DO DOCENTE}

Neste ponto mostra a formação como músico do docente, ao começar a caminhada na música, á conhecer seus colegas que incentivaram a crescer na carreira como músico. Nesse capitulo também encontramos como foi que alcançou sua formação superior. Este ponto também traz sua atuação como docente e os locais de atuações, que é uma escola de ensino fundamental e a atuação em um projeto social. Com uma melhor performance na música começou então a dar aulas de instrumento. Com aulas particulares de violão e oferecendo oficinas de musicalização e ritmos através da prática.

O docente declara conhecer diversos materiais que auxiliam em suas estratégias de ensino, e declara que faz uso de vários materiais didáticos para o conhecimento próprio de determinado tema. Essa busca de orientação de um determinado tema, ele faz uso para o ensino coletivo. Mostra também como o docente trabalha e como ele entende a respeito sobre esta modalidade de ensino com qual trabalha. Declara sua forma de trabalho e que caminhos usa para levar conhecimento aos seus alunos de instrumento.

Um docente não nasce qualificado e pronto para assumir uma sala de aula, mas o professor se torna excelente quando busca um aperfeiçoamento, Lehmann; Sloboda; Wood, (2007 apud ULLER, 2012). Ao longo dos anos que atuou com professor de instrumento, surgiu o interesse em cursar um curso superior, onde atualmente se encontra graduado em "Licenciatura em Música". Durante o período em que estudava a graduação teve a oportunidade de estudar em grupos de instrumentos, tocando estilos variados de música. Durante alguns semestres que estava cursando a licenciatura o professor estudou vários estilos musicais clássicas, folclóricas e populares tudo voltado para interpretações coletivas no instrumento que era o violão.

\section{ANALISE DO ESTUDO DE CASO}

Metodologia tem como definição um processo de reflexão e analise da realidade através da utilização de métodos e técnicas para compreensão detalhada do objeto de estudo, Oliveira (2008). De acordo com o professor sua definição de 
metodologia é; um modelo ou formato criado pelo professor para dar sequência em seus ensinamentos, conjuntos de técnicas para elaboração de projetos.

O professor salienta que é importante o uso da metodologia para não se perder no caminho e que a metodologia que usa com maior frequência é; trabalhar a sua criatividade aliada aos estudos feitos.

Existem alguns materiais que servem para o apoio do ensino da música livros, partituras equipamentos, TV e DVD, materiais de informática, tudo para o entendimento e aprendizado da música, Oliveira (2005).

O professor conhece os materiais porem não os usa em suas atuações. Geralmente emprega a sua criatividade juntamente com a dos alunos. Os materiais didáticos livros, apostilas, materiais próprios de música e vídeo aulas, o docente define como sua metodologia. O material didático serve como caminho para ilustrar ou afirmar o conteúdo da aula. Oliveira (2005). O professor destaca que ele se orienta nesses materiais em suas práticas nos estudos feitos que irá ministrar.

O repertório apresentado pelo professor é bem aceito pelos alunos, de forma que não foi possível constar sua interferência na motivação dos mesmos. De acordo com a entrevista do professor os alunos realizam as atividades com prazer e entusiasmo, demonstrando claro interesse nas aulas de instrumento, sendo possível compreender a partir de então o porquê do envolvimento dos alunos.

\section{CONCLUSÃo}

Neste momento onde que as escolas de ensino fundamental adotaram a música como disciplina, a música vem se fortalecendo nas comunidades. Fazendo com que o professor de instrumento se torne visível dentro de um contexto de ensino musical. Mas para que haja um ensino adequado e significativo nas escolas ou instituições de ensino da música, o professor deve conhecer ações e bons planejamentos para alcançar seus objetivos. É fundamental conhecer metodologias aplicadas juntamente com a experiência do docente para se levar os conceitos musicais aos alunos através do ensino. 
O ensino coletivo de instrumento musical tem sido usado em variadas instituições de ensino. Com isso os professores sistematizam metodologias para cada realidade encontrada seja em escolas livres de música, projetos sociais ou instituições que são usadas para o ensino da música.

O resultado mostrou que o professor conhece vários tipos de materiais didáticos para o uso da prática de ensino, que são: livros, métodos de música, apostilas, revistas, cifras, partituras, PDFs, aparelhos de som, DVDs, CDs, vídeo cassetes, fitas VHS, softwares, celulares, gravadores, sites e endereços eletrônicos como Youtube, Cifra Club e blogs. Esses materiais didáticos ficam à disposição do professor, só que o docente prefere usar a criatividade dele e dos alunos para realizar suas aulas.

Pode-se afirmar que a pesquisa mostrou que o professor considera muito importante a utilização de uma boa metodologia em sua prática, afirma que o professor precisa se apoiar em algum tipo de metodologia.

A pesquisa mostrou que os critérios que o professor utiliza para a seleção da metodologia é fazer um reconhecimento do que os alunos sabem, um apanhado porque o professor acredita que uns podem desenvolver mais do que os outros, de acordo com o interesse de cada um.

O ensino coletivo de instrumento possui pontos positivos e pontos negativos afirma o professor. Mas com o uso de uma boa metodologia e um bom planejamento, a aula de ensino coletivo de música se torna eficaz e produtivo. O professor acredita que a metodologia é importante para a sua pratica, e quando quer abranger um tema especifico com seus alunos procura se apoiar em metodologias que agregam sobre o tema especifico.

Este trabalho faz-se necessárias pesquisas futuras a fim de se verificar de forma aprofundada sobre o ensino coletivo, profissionais que possuem experiência prática na área de atuação, sem e com formação acadêmica especifica que tem oportunizado a realização de projetos sociais. 


\section{REFERÊNCIAS}

BOGDAN, Robert; BIKLEN, Sari. Investigação qualitativa em educação: uma introdução à teoria e aos métodos. Tradução Maria João Alvarez, Sara Bahia dos Santos e Telmo Mourinho Baptista. Porto: Porto Editora, 1994.

CRUVINEL, Flávia Maria. Educação Musical e transformação social - uma experiência com ensino coletivo de cordas. Instituto Centro-Brasileiro de Cultura. Goiânia, 2005.

FREIRE, Vanda Bellard. Horizontes da Pesquisa em Música. Rio de Janeiro: 2010.

GIL, Antônio Carlos. Como elaborar Projetos de Pesquisa. 5a. Edição. São Paulo: Atlas, 2010.

GREEN, Lucy. How popular music learn: a way ahead for music education. London Institute of Education. Ashgate, 2002. 238p.

ISSICABA, I. Contribuições da pratica coletiva de violões para o aprendizado do violonista 2010. 49. Trabalho de conclusão de curso (Bacharelado em música - Violão) - Universidade de Estado de Santa Catarina, Florianópolis. 2010.

LEHMANN, Andreas C.; SLOBODA, John A.; WOOD, Robert H. Psychology for Musicians: Understanding and Acquiring the Skill. Oxford; New York: Oxford University Press, 2007.

OLIVEIRA, F. A. Materiais didáticos nas aulas de música: um survey com professores da Rede Municipal de Ensino de Porto Alegre - RS. Dissertação de Mestrado (Educação Musical). 2005, 120p, Universidade Federal do Rio Grande do Sul. Porto Alegre, RS.

OLIVEIRA, Maria Marly de. Como Fazer Pesquisa Qualitativa. 2. Ed. São Paulo: Editora Vozes, 2008.

PIZZATO, Miriam Suzana; HENTSCHKE, Liane. Motivação para aprender musica na escola. Revista da ABEM, Porto Alegre, n. 23 40-47, mar. 2010.

REQUIÃO, Luciana. Escolas de música alternativas e suas particularidades: uma opção para a formação profissional do músico. Cadernos do Colóquio, p. 98-108, 2001. 


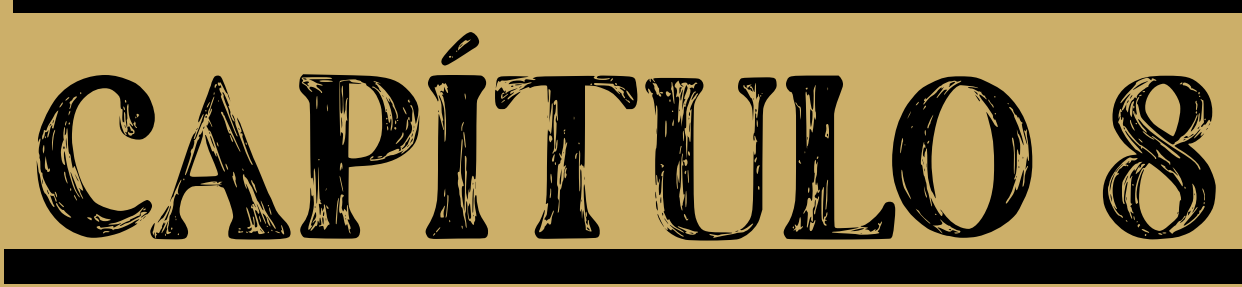

\section{ARTE NA EDUCAÇÃO INFANTIL: IMPACTOS E TRANSFORMAÇÕES NA FORMAÇÃO DOS DOCENTES DA PRIMEIRA INFÂNCIA ART IN THE KINDERGARDEN: IMPACTS AND TRANSFORMATIONS IN THE PRACTICE OF THE EARLY CHILDHOOD EDUCATORS}

Alexandre Santiago da Costa ${ }^{1}$

1 Doutor em educação pela Universidade Federal do Ceará. Mestre em Artes pela Universidade Federal da Bahia. Pedagogo. Professor Adjunto da Faculdade de Educação da UFC. Coordenador do grupo de pesquisa e estudos em educação e ludicidade (GEPEL.ce). Ator e diretor teatral. E-mail: santiagoalexandre@yahoo.com.br 
RESUMO: O presente artigo tem por objetivo geral discutir os impactos e transformações de uma formação ludoestética em contexto na prática pedagógica do educador infantil para o ensino de artes visuais. O trabalho discute a formação a partir de princípios éticos, políticos e estéticos que estejam atrelados a experiências no brincar e nas interações sociais. Nos questionamos Qual o lugar e função do lúdico nas práticas formativas em contexto que visam à formação estética dos educadores infantis? Inicialmente, os pilares teóricos de sustentação deste projeto repousam sobre os trabalhos de: Formosinho (2013), Imbernon (2010), Pimenta (2010) e Tardiff (2002), no que se refere à formação docente; Vygotsky (1989), Benjamim (1984), Brougère, Winnicott, no que concerne as práticas lúdicas.

PALAVRAS-CHAVES: ludoestética, formação do educador infantil

ABSTRACT: The main goal of this is article to investigate the impacts and transformations of ludic and esthetic training in context on pedagocical practice of child educator at work with visual arts. Considering the nem demands pointed by the early childhood (DCNEI) of 2009, at which point the pedagogical work from political and esthetic, ethical principles that are fied to experiences in play and in social interactions. We what impacts of ludic and esthetic training in pedagogical practices in children educators? The theoretical pillars of support of this project lie on the work of: Formosinho (20013), Imbernón (2010) and Tardiff (2002) with regend to teacher training; Vygotsky (1989), Benjamin (1984), Brougeré (2000), in playful practices.

KEYWORDS: Esthetic. Playful practices. Children educators training.

\section{INTRODUÇÃO}

O presente artigo é um recorte de uma pesquisa de doutorado que discutiu a importância das práticas lúdicas na formação estética do educador infantil para o trabalho com as artes visuais. A questão central do trabalho é como uma formação em contexto e de forma lúdica pode gerar transformações nas práticas das docentes da educação infantil em relação as suas práticas estéticas com as crianças? A pesquisa tem vários achados, mas aqui apresentarei como a prática de uma professora foi transformada a partir de uma formação ludoestética, realizada no que chamamos de formação continuada em contexto.

A partir de minha experiência como formador de professores, percebo a pouca relação entre os contextos de trabalho dos docentes e seus processos de 
formação continuada. A formação em contexto é um contínuo da formação docente profissional inicial, tendo o diferencial de ter no seu processo algo mais concreto e contextualizado a partir das demandas do educador e das demandas do seu lócus de trabalho docente. Tal modalidade formativa está no âmbito do lócus de trabalho docente, e é gerida a partir da situação concreta da instituição e não uma prática formativa abstrata e descontextualizada.

Para pensar na formação continuada dos educadores infantis para o ensino de artes é necessária a reflexão acerca do currículo da educação infantil. As diretrizes curriculares oficiais apontam a estética e a ludicidade como dimensões prioritárias para as vivências formativas das crianças. Tais diretrizes curriculares apontam três princípios básicos para balisar o currículo da educação infantil, o princípio ético, o princípio estético e o princípio político. A brincadeira e a arte constituem então eixos norteadores da transposição desses pilares para a prática pedagógica da educação infantil, portanto, tais pressupostos não podem ficar fora da formação dos educadores das crianças.

Neste sentido, as Diretrizes Curriculares para a Educação Infantil (DCNEI, 2009) em seu artigo $3^{\circ}$ nos trazem que:

O currículo da Educação Infantil é concebido como um conjunto de práticas que buscam articular as experiências e os saberes das crianças com os conhecimentos que fazem parte do patrimônio cultural, artístico, ambiental, científico e tecnológico, de modo a promover o desenvolvimento integral de crianças de 0 a 5 anos. (p.18)

De acordo com (Kishimoto, 2010), para a construção de um currículo "assertivo" que subsidie o trabalho pedagógico nas instituições de educação infantil se faz necessário pensar concepções de criança, infância, cultura, estética, do brincar e do cuidado. Conhecer quem é essa criança que será inserida neste cotidiano, a que família e a cultura ela pertence, como aprende e se desenvolve são aspectos relevantes a serem considerados para elaboração de um planejamento e práticas educativas que realmente estejam preocupados como desenvolvimento das crianças e respeitem suas particularidades.

A metodologia usada na pesquisa foi a pesquisa-ação que visa uma intervenção e um estudo colaborativo com os atores socais da pesquisa, onde os 
mesmos participam do planejamento das etapas da pesquisa e sua execução. A pesquisa foi desenvolvida com 22 docentes de uma creche situada na periferia de Fortaleza-Ceará. A pesquisa contou com um grupo focal de 3 docentes. Para a composição deste artigo, escolhemos a análise da prática de apenas uma docente deste grupo focal.

\section{POR UMA FORMAÇÃO LUDOESTÉTICA DO EDUCADOR INFANTIL PARA O ENSINO DE ARTES VISUAIS}

A formação de professores, segundo Flores apud Moraes (2003), constitui um processo que implica uma reflexão permanente acerca da concepção, organização e operacionalização das demandas formativas na sociedade, encarando o ensino e suas demandas contemporâneas e reflexão constante sobre o que é ser professor em um determinado contexto social.

Já a formação em contexto é um viés importante da formação continuada, pois é centrada nas realidades de atuação e baseia-se no envolvimento dos profissionais nos processos de melhoria e mudanças das suas práticas individuais e institucionais.

Como afirmam Nogueira e Rodrigues (1990) Citado por Silva Apud Moraes (2003);

O sistema de formação contínua de professores deve ser concebido a partir da escola. Esta é o núcleo privilegiado de formação, porque é nela que se gera a profissão, se desenvolvem novos processos, técnicas e métodos, se realiza o ajustamento entre a teoria e a prática, se reforçam os valores da responsabilidade e da necessidade de inovação (p.111)

A profissionalidade e a relação de saberes conjugados para a qualidade da prática docente perpassa processos que estão ligados a contextos diversos da vida dos professores e das instituições em que trabalham. Entender tais processos é condição necessária para pensar na formação docente.

E o que é uma formação ludoestética? Entendendo lúdico como um processo de criatividade e imaginação do ser humano, catalisado pelas suas experiências pessoais e que encontra na arte um grande aliado dessa fomentação de imaginação e criatividade. O lúdico tem intrínseca relação com a arte, pois partem 
de sentidos socioculturais e pessoais. Pensar em uma formação ludoestética é atrelar aos processos formativos docentes, imaginação, autonomia criativa e expressão de si e do mundo.

Na formação lúdica e estética dos professores de educação infantil deve haver uma forte dimensão subjetiva que dialoga com os saberes culturais oriundos das experiências de vida e de formação profissionalizante. Segundo Tardiff ( 2013);

Na realidade, no âmbito dos ofícios e profissões, não creio que se possa falar do saber sem relacioná-lo com os condicionantes e com o contexto do trabalho; o saber é sempre o saber de alguém que trabalha alguma coisa no intuito de realizar um objetivo qualquer. Além disso, o saber não é uma coisa que flutua no espaço; o saber dos professores é o saber deles e está relacionado com a pessoa e a identidade deles, com a experiência de vida e com a sua história profissional, com suas relações com os alunos em sala de aula e com os outros atores escolares na escola, etc. (p.11)

Pensar na formação docente é trabalho complexo, pensar na formação do educador infantil é complexo e específico sob alguns processos que estão relacionados a esse nível de ensino. A formação inicial profissional não basta e não dá conta da complexidade do trabalho educativo que tem na práxis pedagógica seu processo central, dialogando teorias e práticas pedagógicas. Há a preconização do trabalho com as múltiplas linguagens na educação infantil e isso não condiz com o currículo dos cursos de formação inicial. Então, a formação continuada faz-se mister.

A arte e a ludicidade vêm sendo preteridas em favor de conhecimentos e fatores pragmáticos na evolução da humanidade. Um dos males da nossa sociedade, imersa na condição pós-moderna é a angústia da própria condição humana. Os escapes dessa angústia angustiantes só são sentidos e saboreados por uns poucos, consistindo um privilégio dos que dispõe de ócio. O ócio, que segundo o Filósofo Domenico de Masi é extremamente necessário e criativo, e precisa ser estendido a todos, como uma tentativa de devolver a esse homem sua natureza lúdica e não apenas racional e pragmática. O ócio possibilita significativos processos criativos em arte. Isso me remete ao tempo na prática da educação infantil, um tempo racional, robotizado e inflexível, sem espaço para a criatividade e para o desejo que foge as " GRADES" curriculares. 
Pensar na formação ludoestética era colocar as professoras em contato com as práticas lúdicas e estéticas, com os " brincares" e com as linguagens da arte e do brinquedo. Consideramos os saberes ludosensíveis, que são saberes que são de âmbito da sensibilidade, da expressão e da subjetividade humana, comumente relegado na racionalidade técnico-instrumental da formação docente. Tais saberes permearam toda a formação, com apreciação de filmes, oficinas de brinquedos, práticas lúdicas corporais, visitas a ateliês de artistas e exposições e rodas de conversa. Pensar nas estratégias lúdicas era também refletir sobre a ampliação cultural das educadoras.

A pesquisa teve 4 fases. A primeira foi a fase diagnóstica, com encontros para pensar a formação e observação participante. A segunda fase foram as oficinas lúdicas, as rodas de conversa sobre suas práticas, visitas as exposições e planejamento. A terceira fase foi a observação das práticas depois de 1 ano de formação em contexto. A quarta e última fase foi a devolutiva da pesquisa para as docentes e a instituição.

Nas primeiras sessões fizemos dinâmicas de apresentação e dinâmicas para elas explicitarem seus desejos quanto a formação. Fizemos oficinas para diagnosticar suas percepções sobre o trabalho com artes com as crianças. Tal diagnóstico iria ajudar, juntamente com minhas observações de suas aulas, no planejamento da formação.

A partir do exposto, passei 3 meses observando as práticas das docentes e participando dos seus momentos de planejamento. Muitas inquietações surgiram dessas observações e fui fazendo encontros para discutirmos os rumos da formação. Percebi pelas primeiras aproximações com as práticas artísticas das professoras que a arte tinha um caráter reprodutivo e muito ligado às datas comemorativas, sem uma intencionalidade de buscar significados e expressões para as crianças As docentes pediram para fazermos um estudo mais prático, pois as formações que tinham, no âmbito da prefeitura, eram muito teóricas. Decidimos então, promover encontros para discutir tais questões. Distribui textos sobre a temática e no dia marcado as docentes trouxeram discussões suscitadas pelo debate acerca da definição acerca de arte, estética e o brincar. Essas inquietações nos levou a duas visitas a duas exposições de artes visuais em um espaço cultural da cidade. 
O debate também acerca do conceito de arte, trouxe um discurso que estava atrelado ao belo e ao artesanato ou trabalhos manuais. Então vislumbrei nas exposições escolhidas que eram de arte contemporânea, um bom manancial de elementos para refletirmos o que é e para que serve a arte na sociedade, bem como, na educação. Lancei a proposta para as professoras que adoraram a ideia da visita, pois a maioria nunca tinham ido a uma exposição de arte.

As exposições escolhidas foram "XVIII UNIFOR PLÁSTICA" e "Adriana Varejão; pele do tempo" ambas de arte contemporânea no Espaço Cultural da UNIFOR (Universidade de Fortaleza). As visitas trouxeram intensas reflexões sobre o que é arte, o objeto de arte, a beleza na arte e trouxe muitas inquietações. Eu fui uma semana antes para visitar e poder conhecer antes das professoras para preparar a mediação. Quando me deparei com as obras da Adriana varejão, fiquei receoso que elas não iriam gostar da exposição pelo conceito que tinham expressado sobre o que significava arte para elas. No dia da visita, guiada por um monitor bem experiente e que trouxe muitas reflexões e indagações para o grupo, percebi o envolvimento e como aquele encontro significou para as professoras. A estética e poética de Adriana varejão é tão intensa e cheia de significados e simbolismo feminista que atingiu as subjetividades daquelas mulheres educadoras. $O$ objetivo do encontro foi alcançado, desequilibrar um conceito e tentar reestruturá-lo, reconstruí-lo.

Na exposição da XVII UNIFOR PLÁSTICA, o que mais chamou atenção foi a diversidade de linguagens que as professoras tiveram acesso, como fotografia, instalação, esculturas, vídeo-instalações, performances, grafite, pintura, desenho, entre tantos outros que trouxeram questões sobre objetos de arte e as linguagens visuais, além das interações com as obras; uma obra de arte também pode pegar e mexer? Elas se perguntaram.

A exposição e suas diferentes linguagens abriu para as educadoras grandes reflexões, pois as diferentes linguagens da arte contemporânea apresentadas às educadoras eram analogicamente ao que se pretende com as múltiplas linguagens no contexto da educação infantil.

A formação tomou um rumo diferente do que eu tinha planejado inicialmente. A formação lúdica cumpria seu objetivo, pois entendemos formação 
ludoestética os processos de diálogo entre o lúdico, a imaginação e a estética, permeadas pela produção cultural e pelas subjetividades e desejos dos sujeitos envolvidos no processo. Elas queriam mais, muito mais. E paralelo aos estudos teóricos, ficávamos atentos a agenda cultural da cidade para irmos visitar exposições.

O acesso aos equipamentos culturais da cidade e suas exposições viraram o mote das formações. A cada visita a uma exposição, a ampliação do conceito de arte e dos processos significativos em arte com as crianças ia acontecendo e atrelado a isso fazíamos encontros na escola para discutirmos o que tinham visto nas exposições e tentávamos inserir essas reflexões nos planejamentos.

A medida que os encontros iam acontecendo, eu acompanhava os planejamentos e oferecia minha ajuda para quem quisesse e me colocava a disposição para pensarmos práticas artísticas com as crianças. No próximo tópico, analisarei uma professora e sua busca por entender sua prática em relação a arte com as crianças. Dei o nome de Tarsila a essa professora.

\section{VAN GOGH E TARSILA NO SÍTIO DE DONA RAIMUNDA: UMA DO- CENTE E SUA PRÁtICA DE ENSINO DE ARTE}

A professora Tarsila é pedagoga com mais de 20 anos de experiência na educação, não possui especialização e das três professoras pesquisadas no grupo focal é a mais experiente e já tem idade suficiente para se aposentar, segundo ela, a arte é muito importante para ela, mas, como apreciadora, não tem muito “ jeito" para as artes. Na sua formação a arte aparece, de forma superficial: A arte na minha graduação foi trabalhada como apreciação da arte contemporânea, autores e pintores famosos e a arte como pintura, recorte, colagens, digamos que o básico. ( Tarsila - transcrição/ entrevista)

Desde o primeiro momento, ela ponderou que não tinha muita afinidade com as artes, mas queria aprender. Por isso, se colocou como voluntária para o grupo focal. A professora chegava a pagar para outras pessoas decorarem sua sala, pois, segundo ela, " não tinha jeito":

Trabalho na construção e expressão, a criança desenha, pinta, recorta, cola, canta, dança, vejo isso como arte. Arte é expressão. O desenho é 
o mais desejado por eles. Acho-me um pouco equivocada em relação a minha prática com arte. Creio que não caminho bem com o desenho e pinturas, aprecio, mas não sou boa facilitadora.

Tarsila traz uma análise bem pontual da sua prática: consegue entender arte, aprecia, mas não consegue ser uma boa facilitadora dessas linguagens artísticas. Percebi isso nas mediações que observei. Ela não se permitia experimentar com as crianças, mas realizava excelentes intervenções nas rodas de conversas, tinha uma escuta sensível para as falas das crianças, mas não conseguia transpor as ideias e as estéticas do artista para uma dimensão metodológica. Precisei intervir nos seus planejamentos, dialogando a partir de algumas obras, suscitando que ela interviesse com as crianças além da espontaneidade, da livre expressão, mas que propusesse técnicas, metodologias ricas, suportes variados.

Tarsila tem uma postura bem diferente das outras professoras do grupo focal em relação às interações com as crianças. Tem uma característica marcante que é de uma intensa escuta dos seus alunos. Eu percebia uma grande sensibilidade por parte da educadora, de acolhimento e de valorizar as vozes das crianças. Tal postura é uma mediação que amplia muito o repertório e o protagonismo infantil.

A professora instiga muito os alunos a se perceberem e valorizarem suas ideias, fornecendo e construindo conhecimentos a partir das rodas de conversa, elaborando materiais simbólicos que serão a base da produção artística. Percebe-se uma tentativa de suprir, na sua prática pedagógica, algumas fragilidades metodológicas com suportes e técnicas variadas para enaltecer o viés apreciativo e de contextualização das obras trabalhadas. A professora precisava sempre de um suporte no planejamento de suas sequências didáticas. Todas as vezes que me encontrava na escola, pedia sugestões para trabalhar suas obras.

A escola estava realizando um projeto de artes e cada professor escolheu um artista. O artista escolhido por Tarsila foi Van Gogh. Passamos então a estudar esse artista, sua vida e obras. Passei alguns filmes e documentários para Tarsila se inspirar e se informar. Ela começou a trazer algumas obras para as crianças apreciarem nas rodas de conversas no início da aula.

Certa vez, Tarsila tinha mostrado a obra campo de trigo e silvestre do pintor Van Gogh e as crianças gostaram muito. A sala de Tarsila ficava no primeiro andar e de lá as crianças podiam avistar um terreno que ficava ao lado da escola, 
e lá tinha uma plantação de milho. Uma criança ao fazer a apreciação da obra do artista, imediatamente comentou que parecia muito o milharal de D.Raimunda, como era conhecida a proprietária do terreno vizinho.

\section{Observação - infantil 5}

A professora faz uma roda de conversa antes de irem a uma plantação de milho que tem atrás da escola. A professora já foi pedir a autorização à proprietária do terreno, Dona Raimunda.

Inicio da roda de conversa.

- O que vocês sabem do Van Gogh?

-ele fez um quadro.

- ele fez um quadro?

- ele fez um quadro e deu pra mãe dele.

- ele fez um quadro e deu pra mãe dele? E o que foi mais que o van Gogh fez que vocês lembram?

- ele foi embora.

- ele foi embora pra onde?

- pro céu.

- ah ele morreu. E o Lucas, o que é que o Lucas sabe sobre esse pintor?

- ele pintou esse quarto pro seu pai e sua mãe. Ele deu a sua cama, as suas roupas.

- criança 2- ele pintou, não, Lucas? Ele pintou e deu o quadro. A mãe dele tava com saudade e queria noticia ai ele pintou o quarto dele. Ele não deu o quarto dele, senão onde ele ia dormir?

- ah legal, e vocês lembram que lá no atelier nós usamos uma lixa, e na lixa nós fizemos uma arte sobre o quadro do Van Gogh. Qual era?

- a lua, o sol.

- o que mais?

- a noite. Na noite não tem sol.

- a gente viu um quadro que é sobre a noite, como era essa noite, como era?

- as estrelas brilhavam.

- ah, as estrelas brilhavam. Era a noite estrelada de Van Gogh, e hoje a gente vai ver outra obra dele. O que vocês estão vendo aqui? O que é, Hugo?

- um campo, um pássaro voando ai...uma horta.

- ai tem horta? E tu, Bruna, o que tu tá vendo ?

- uma plantação.

- e vocês sabem onde tem aqui no bairro perto de vocês um lugar parecido?

- ali, atrás do muro.

- já foram lá? E parece mesmo com isso aqui?

- parece e tem um bocado de comida e um papagaio que fala.

Uma criança já conhece os proprietários do sítio.

- ah, legal, aqui é o campo de trigo. Trigo é essa planta de que se faz o pão. É o campo de trigo de Van Gogh. Como vocês acham que a gente deveria pintar uma coisa parecida com essa?

- é só a gente ficar olhando e a gente fazer.

- mas fazer com que material?

- tinta ou lápis. Ou lápis de escrever ou lápis de pintar.

- que outros materiais a gente podia usar aqui ?

- lápis de cera. 
- mas o Van Gogh pintou com tinta o quarto dele e ai também.

- será que em todas as obras de Van Gognh ele usava tinta? E se a gente colocasse a cadeira para subir e ver o campo da Dona Raimunda? Será que daria certo? E se a gente, em vez de pintar, a gente fotografasse a nossa obra que já está lá?

- se a gente for lá, tudo o que a tia falar o papagaio vai imitar.

- (risos) é mesmo? Tudo o que eu falar o papagaio vai me imitar? Então será que a gente podia botar o papagaio no quadro do Van Gogh? O que vocês acham?

- simmmm. (gritos)

A professora conduz as crianças que irão fotografar o milharal de Dona Raimunda. Saem da escola e percorrem em fila as ruas da comunidade, chamando atenção por onde passam, até chegarem ao sítio de Dona Raimunda. Lá eu empresto minha câmera fotográfica, ensino como manusear e digo para elas, uma a uma, tirarem as fotos que quiserem, lembrando do quadro do Van Gogh.

Obs: o papagaio não falou nada, ficou assustado com tantas crianças. (as crianças vão fotografar o campo da Dona Raimunda)

\section{Figura 1 - Visita ao sítio de D. Raimunda - crianças do inf. 5}

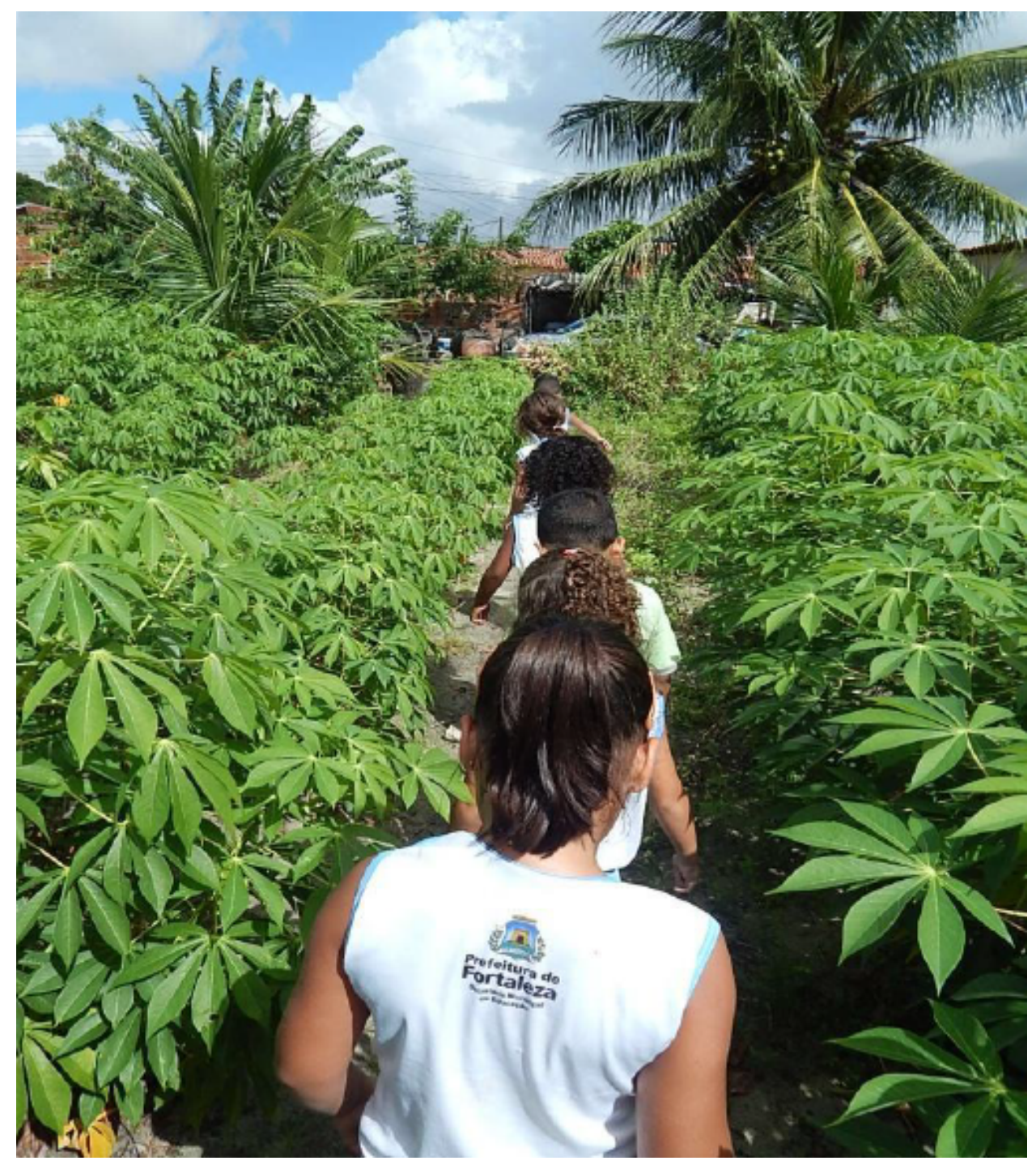

Fonte: Fotografia do autor. 


\section{Figura 2- Obra “ Campo de trigo e silvestre” Vincent van Gogh}

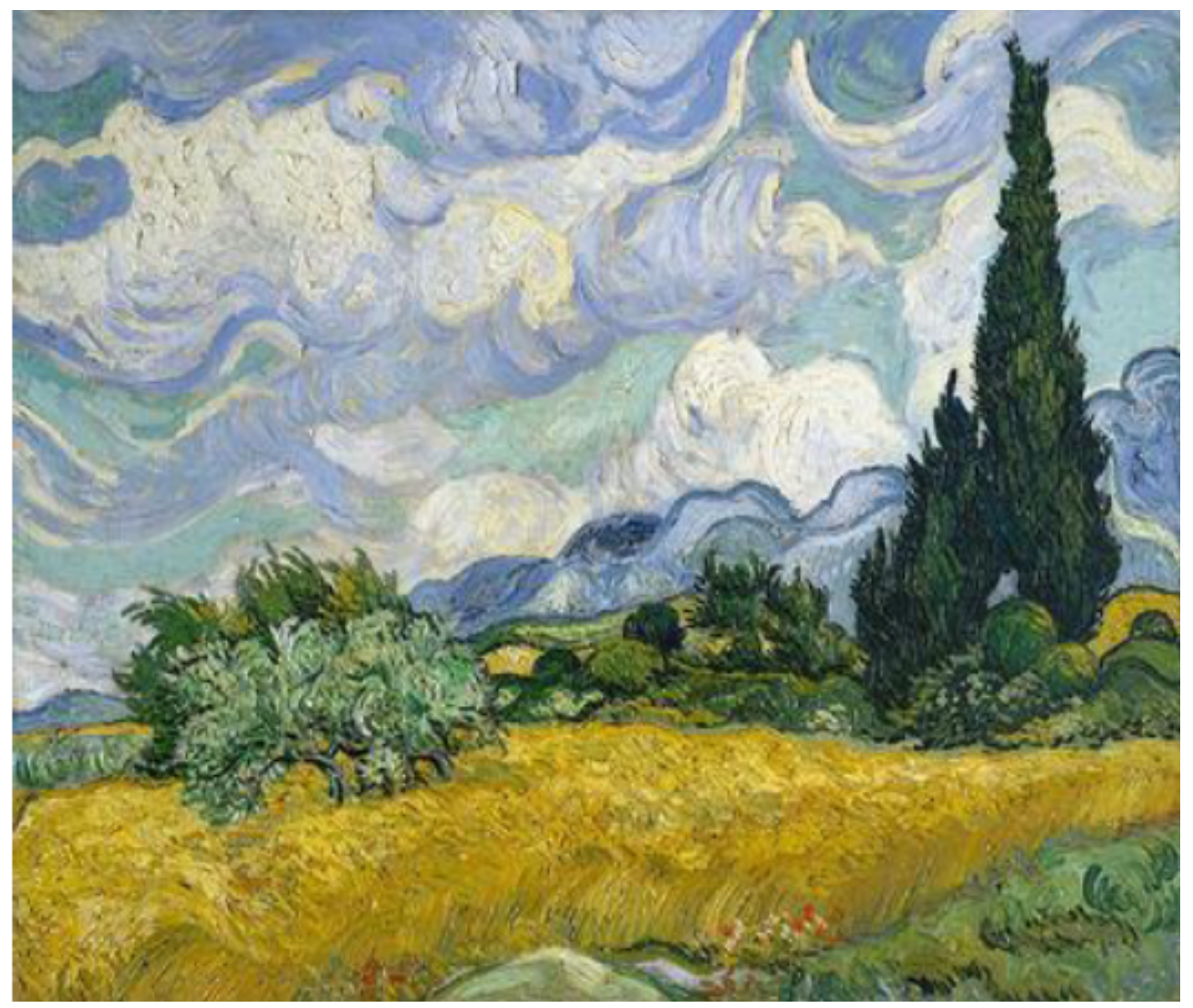

Fonte: Wikipédia.

Figura 3- Foto - Milharal de Dona Raimunda

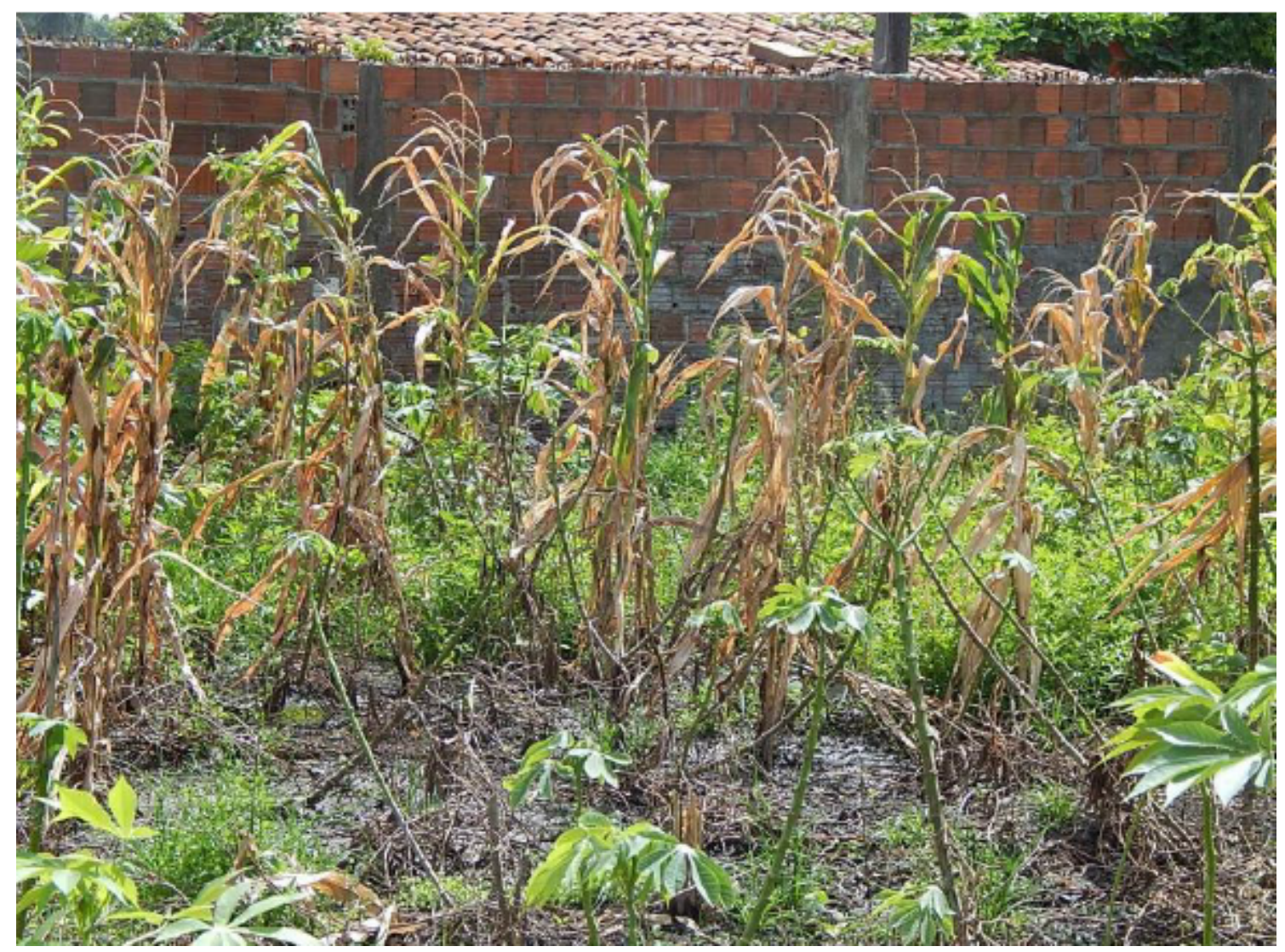

Fonte: fotografia de Gabriela 5 anos 
Esse relato foi uma das ações do projeto. As crianças usaram a fotografia para registrar o milharal. Todas as crianças usaram a máquina fotográfica. Fizemos uma oficina rápida para eles manipularem a câmera fotográfica. Escolhi a fotografia acima para ilustrar essa ação.

Lidar com o lúdico e as relações simbólicas que ele fomenta na imaginação das crianças é relacionar o prazer de jogar com sua imaginação e seu contexto de vida. A vida pode também ser um manancial de possibilidades criativas, colorindo a realidade. Uma plantação de milho parte de uma paisagem rotineira a que o olhar se acostumou torna-se extraordinária pelo jogo lúdico da arte, pela mediação sensível e atenta das vozes das crianças e suas percepções do mundo. Segundo Pillar (2009, p.197) no seu livro " A educação do olhar" :

\begin{abstract}
A imaginação criadora permite à mente infantil percorrer caminhos que conduzem a outros tempos e espaços. Dinâmica da sensibilidade que permite descobrir realidades insuspeitas e mundos novos, tornando-se meio direto de aprendizagem ao transportar a criança a uma temporalidade fictícia e a um espaço interior maravilhoso, conduzindo-a do conhecido ao desconhecido. E não é esta a própria questão de toda pedagogia que se nega a ser só reprodução?
\end{abstract}

Analiso o trabalho de Tarsila como um processo de transformação ainda em movimento, sempre na busca de práticas significativas para o trabalho com as crianças. Há uma característica marcante e decisiva no processo em arte que é ser um facilitador dos discursos e investigador das percepções das crianças, registrando inclusive essas percepções e falas, o que é crucial para uma prática reflexiva. A professora possui uma postura bem crítica perante a conjuntura política da educação pública que ressoa na sua prática, inviabilizando práticas mais significativas, além de ser uma grande liderança no grupo. Contudo, desde o início da pesquisa Tarsila se mostrou preocupada em relação às suas habilidades para o trabalho com artes visuais, várias vezes relatou "não ter jeito para atividades manuais" . Como foi analisado, na condução desse projeto específico, ela teve dificuldades em planejar de forma mais criativa as ações para o fazer e a produção com as crianças, o que foi fruto de uma dimensão instrumental fragilizada na metodologia da práxis pedagógica em artes visuais nas formações.

Tarsila é fruto de um processo transformador de formação em contexto que se utilizou de estratégias formativas lúdicas e com experiências estéticas mar- 
cantes e transformadoras; houve uma educação do olhar da professora Tarsila que perpassou por ações que culminaram também com a formação estética das crianças. A pesquisa-ação resultou em um compartilhamento de possibilidades e de estéticas que foram marcando uma nova postura de trabalho, uma mudança que se desloca de ações mecânicas para ações significativas, fruto de uma diretriz curricular para o ensino das artes construída coletivamente. Uma constatação nessa perspectiva da mudança das práticas de Tarsila foi perceber pela sua prática e depoimentos que a arte começou a ter um sentido e uma compreensão, uma consciência estética e tal consciência impactou suas práticas pedagógicas, dialogando com as demandas curriculares oficiais (DCNEI) que apontam o trabalho da educação infantil como princípio ético, estético e político.

\section{CONSIDERAÇÕES FINAIS}

A formação de professores para o trabalho curricular com a arte e a ludicidade deve priorizar as limitações e potencialidades do professor que antes de mais nada é detentor de uma cultura estética e lúdica gerada na infância. A capacidade lúdica do professor é um processo que precisa ser vivenciado e não apenas estudado teoricamente. As práticas e vivências lúdicas relacionam identidade, potencialidade e desejo, elementos formativos importantes para qualquer sujeito.

A estética também é um elemento essencial na formação dos educadores em geral, não apenas os educadores da primeira infância. O brincar também é um elemento estético na medida em que a criança utiliza-se da linguagem do brinquedo como instrumento expressivo de comunicação de ideias e sentimentos. Além dos jogos e brinquedos serem impregnados de uma formatação que chamam a atenção das crianças pelo design e aproximação com sua cultura infantil.

Essa relação da ludicidade com a formação de professores leva ao crescimento dos sujeitos envolvido em um processo formativo sensibilizador e significativo do ponto de vista da identidade docente em que os docentes agem reelaborando suas experiências, abrindo um canal de autonomia diante de sua práxis docente.

Ao falarmos de arte e brinquedo, falamos da inteireza de ser educador e acrescentamos segundo OSTETTO (2004): 
Pólos de competência e compromisso, o pólo da sensibilidade- que abre caminho para o encantamento, o maravilhamento, ingredientes essenciais para a recriação do cotidiano pessoal e profissional, rompendo com a forma, ousando outros desenhos para o dia-a-dia. Novas paisagens subjetivas. (p12)

E falando de novas paisagens que se abrem pela formação ludoestética, finalizamos com um destaque ao enriquecimento da experiência estética, e da capacidade de pensá-la e de narrá-la em nossos dias, por parte de educadores e crianças. Os filósofos Walter Benjamim e Theodor Adorno foram os primeiros a diagnosticar tal questão e as suas consequências para a formação humana. As experiências estéticas que fundam a emancipação de um espirito livre e crítico a cultura de massa e seus estereótipos devem ser a tônica dos processos de formação de professores com vistas a inserir no campo experiencial de suas vidas um simbolismo transformador e por que não dizer lúdico. Pensar a estética e o lúdico e sua significativa experiência formativa para o educador de crianças é ampliar a cultura e a gramática social desse educador em detrimento de uma arte pedagógica e racionalmente técnica para a formação conceitual desses educadores

\section{REFERÊNCIAS}

BARBOSA. Ana Mae. A imagem no ensino da arte. São Paulo: Perspectiva, 1991.

BRASIL. Câmara de Educação Básica. Diretrizes Curriculares Nacionais para a Educação Infantil. MEC. Brasília:\ SEl, 2009.

MORAES, Maria Célia. Formação de professores; perpectivas educacionais e curriculares. Porto/Portugal ; Porto Editora, 2003.

KISHIMOTO, Tizuko M. Jogos Tradicionais Infantis. Petrópolis. RJ. Vozes. 1993.

OSTETTO, Luciana Esmeralda. Arte, infância e formação de professores: Autoria e transgressão/Luciana Esmeralda Ostetto, Maria Isabel Leite. Campinas, SP: Papirus, 2004.

PILLAR, Analice Dutra (Org). A educação do olhar no ensino das artes. Porto Alegre: Editora Mediação, 2009.

TARDIF, Maurice. Saberes docentes e formação profissional. Petrópolis, Rio dee Janeiro: Vozes, 2013. 


\section{$10.48209 / 978-65-89949-09-0$}

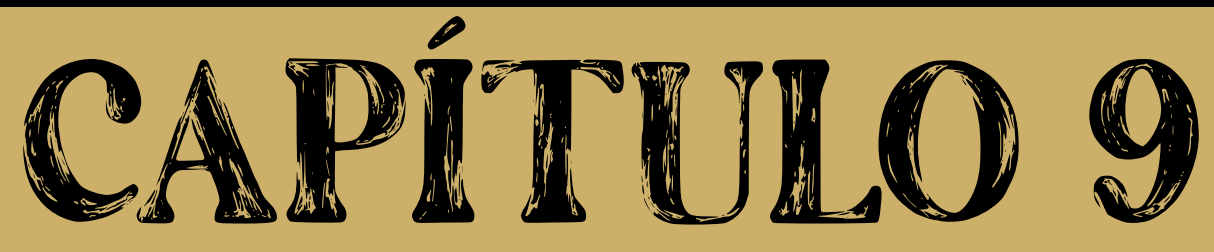

\section{CULTURA POPULAR E ENSINO DE ARTE - PROCESSOS IDENTITÁRIOS}

Christiane de Faria Pereira Arcuri ${ }^{1}$

1 Professora Adjunta de Artes Visuais e História da Arte, Instituto de Aplicação - CAp, Universidade do Estado do Rio de Janeiro - UERJ.

http://lattes.cnpq.br/5702844883631502, https://orcid.org/0000-0001-6554-3282

E-mail: arcuriarte@gmail.com 


\section{CULTURAS - TRANSITORIEDADES CONCEITUAIS}

A temática central abordada no texto paira acerca da difusão do que se entende como cultura popular no ensino de Arte - da educação básica à pós-graduação, atravessando a formação acadêmica de licenciandos - desde suas conceituações transitórias à sua aplicabilidade pedagógica.

Uma vez que o conceito de cultura popular e suas derivadas definições rondam e expandem o termo na área das Humanidades, abarca também os ensinos voltados à historiografia da arte e à cultura visual cotidiana. Venho, no decorrer das últimas duas décadas, procurando difundir as expressões e manifestações de diferentes tradições civilizatórias com o intuito de elucidar aos discentes a importância de conhecer (hoje) seus antecedentes - percursores da formação de suas próprias raízes culturais - para o entendimento do seu processo identitário.

O termo cultura vem obtendo muitas definições nos últimos tempos. No sentido figurado começa a ser utilizado, com mais frequência, no século XVIII. $E$ vai tornando-se comumente conhecido quando seguido de um complemento e em conjugação com uma área específica, por exemplo, como cultura das artes, cultura das letras, cultura das ciências etc. Estudos sobre o termo cultura, ainda, nos indicam que sua acepção pode referir-se a um estado do espírito circunstancial para uma sociedade ou um dado indivíduo.

Cultura ou Civilização, segundo Thompson (2009), tomada em seu sentido etnológico amplo, inclui conhecimento, crença, arte, moral, lei, costume e todas as demais capacidades e hábitos adquiridos pelo homem enquanto membro de uma dada sociedade. A condição da cultura, entre as diversas sociedades da espécie humana, na medida em que é passível de ser investigada nos princípios gerais, é um tema apropriado para o estudo do pensamento e da ação humanos (THOMPSON, 2009, p. 171).

Em se tratando de cultura popular, tal termo/tema que the é atribuído, se restringiu por muito tempo aos estudos acerca do prisma do que era considerado como Folclore (o saber do povo). No que concerne à Folclore, especificamente, é costume vê-lo associado à oralidade, à coletividade e a uma dispersão temporal 
que se esvai num passado considerado longínquo e perpetuado pelas gerações. O Folclore inclui, notadamente, saberes e práticas ancestrais, manifestações da religiosidade, mitos, artesanato e até mesmo uma língua específica. A cultura popular, nesse sentido, é bastante fluida e vasta, pois abarca muitos dos aspectos simbólicos e materiais acendidos e compartilhados por uma sociedade, incluindo-se artefatos, crenças, comportamentos, modos de fazer e de viver. Em outras palavras, a cultura popular se institui com o que é tradicional num determinado contexto; na mesma medida que se torna, inevitavelmente, uma espécie de menção ao nativo e ao que perdura - ou o que assim se acredita. Por conseguinte, cultura também pode considerar a hereditariedade e a perpetuação de hábitos e costumes nacionais.

Já no século XX, cultura assume um papel de destaque em relação à estrutura e à organização da sociedade pós-moderna. Os meios de produção, circulação e troca cultural, em particular, têm se expandido, desde então, através das tecnologias e dos processos informacionais: "toda ação social é cultural; todas as práticas sociais expressam ou comunicam um significado e, neste sentido, são práticas de significação" (HALL, 2019, p. 7). De todo modo, qualquer prática social tem uma dimensão cultural; da mesma forma que a prática político-econômica também possuem uma dimensão cultural - até mesmo por não estarem desprovidas da anterior.

Neste sentido, também podem ser consideradas, enquanto cultura, as práticas vitais ou ideologias exercitadas que são mensuradas como lícitas em uma sociedade, a um grupo ou a uma classe tais como as experimentações, definições, interpretações e o entendimento de suas condições alegóricas de existência. Torna-se importante mencionar que indivíduos que pertencem a um mesmo lugar geográfico, ou uma mesma profissão ou, ainda, que pertencem a uma mesma geração não constituem, por tais fatos, uma cultura; fazem-no apenas quando compartilham hábitos de linguagem, manifestações, formas de agir, quadros valorativos de cidadania ou mesmo representações artísticas de uma autoimagem coletiva, como por exemplo.

O conceito de cultura, ou a cultura como conceito, decorre de uma perspectiva mais consciente de nós mesmos. Em outras palavras, a cultura permite tra- 
duzir melhor a diferença entre nós e os outros e, assim fazendo, resgatar a nossa humanidade no outro e a do outro em nós mesmos (DA MATTA, 1981, p. 4).

Pensando assim, pode-se dizer que a centralidade da cultura também impele a vida interior das pessoas, pois atua na composição da subjetividade e identidade, na mesma medida que na fabricação das diferenças dos sujeitos participantes da sociedade contemporânea. Isso está relacionado ao fato de que "[...] os significados são subjetivamente válidos e, ao mesmo tempo, estão objetivamente presentes no mundo contemporâneo, em nossas ações, instituições, rituais e práticas" (HALL, 1997, p. 6). A constituição das identidades sociais é fomentada no interior da representação cultural e expande-se no mundo social através dos alinhavos dos seus respectivos significados narrativos de prática cultural.

O antropólogo Gilberto Velho (1993) procura situar a cultura em nossa sociedade apontando para o fato de que todos os homens e mulheres interagem socialmente e participam, mesmo que inconscientemente, de um conjunto de crenças, valores, visão de mundo, rede de significados entendidos enquanto a natureza humana: "A cultura é um conceito que só existe a partir da constatação da diferença entre nós e os outros" (VELHO, 1993, p. 13). Acredita-se que uma cultura pode ser mais facilmente reconhecida a medida em que se distancia de outros círculos civilizatórios. Se há uma multiplicidade de grupos sociais homogêneos entre si, mas heterogêneos uns dos outros, propicia-se a insurgência de pluralidades culturais em que uma sociedade está submersa. O conceito de cultura, portanto, significa quer o que está imergindo à nossa volta; quer o que existe inerte dentro de nós mesmo que de modo inconsciente - num processo incessante/ininterrupto.

A cultura popular foi paulatinamente expandindo as expressões culturais que se restringiam, até então, apenas como Folclore. No entanto, ainda sob uma visão tradicional, a cultura popular persistiu com valores materiais e simbólicos em manifestações e expressões em diferentes campos, tais como na música, dança, festas, literatura, arte, moda, culinária, religião, lendas, superstições etc produzidos nos extratos considerados inferiores, isto é, pelas camadas iletradas e mais baixas da sociedade. Ao passo que cultura erudita (ou de elite) perdurou por mais tempo, equivocadamente, é bom que seja lembrado, como àquela produzida pelos extratos superiores ou pelas camadas letradas, cultas e dotadas de saber 
ilustrado. Esse antagonismo intransigente, todavia, não é mais sustentado empiricamente - haja vista o que as pesquisas em movimento na historiografia da arte, história cultural, antropologia, sociologia e teoria literária, só para citar algumas, vêm registrando nos últimos tempos.

De certo, o conceito de cultura vem de forma luzente sustentando um sentido bastante heterogêneo, abarcando praticamente tudo que pode ser apreendido em uma sociedade - desde a variedade de artefatos (imagens, ferramentas, casas e assim por diante) até às práticas cotidianas como comer, beber, andar, falar, ler, silenciar (BURKE, 2005, p. 42). Ou seja, ao que é genuinamente do povo, livre de precisão da origem social de suas manifestações culturais/alegóricas.

Pode-se definir, portanto, que cultura popular, por assim dizer, é um conceito gelatinoso, fugidio, objeto de muitas controvérsias e debates que se expandem em muitas frentes e campos interessados no tema. Acredita-se que cultura consiste num conjunto de práticas elásticas e incongruentes que se concretizam nos interstícios da cultura dominante, muitas vezes recusando-a, aceitando-a ou confortando-se a ela. Talvez esta constatação se volte a outras perspectivas, no sentido de ser mais um ponto (de vista) para se observar as especificidades de uma sociedade e sua equivalente produção cultural. Qual seja, a cultura popular se caracteriza por uma combinação de resistências (CHAUÍ, 1986) quase sempre enredadas com juízos de valor, idealizações, homogeneizações e disputas políticas multiplicadas.

O fato é que cultura popular é heterogênea (Ortiz, 1994) e o mais conveniente seria fazermos menção a culturas populares - no plural. Para tanto, refiro-me ao pensamento de Ortiz que se completa ao de Certeau (1995) quando se referem à cultura popular sob um olhar semântico polissêmico; uma cultura comum das pessoas comuns, isto é, uma cultura que se perfaz no cotidiano, nas rotinas inegavelmente corriqueiras - e que se mantém porque revigoradas a cada dia.

As culturas populares são, atualmente, nas palavras de Canclini (2015), prósperas e, ao mesmo tempo, inegavelmente híbridas. A cultura de massa não suprimiu as culturas populares. As culturas tradicionais também não. Podem não ter sido inteiramente incorporadas à ação do Estado ou integraram-se parcial- 
mente nos circuitos comerciais do artesanato, da festa, da música e do turismo. Por razões culturais, mesmo porque é inevitável, compreende-se a urgência do prosseguimento - desde sempre - da produção cultural dos setores populares. Também destacamos as ideias do autor quando alerta que se deve levar em consideração que o popular não se concentra em objetos, apenas. O relevante numa dada cultura são as interações e intercâmbios atribuídos aos significados dos seus exemplares. Quer dizer, a arte popular, por exemplo, não é definida por uma determinada coleção de objetos; nem pelos repertórios de práticas culturais de uma determinada civilização. Um mesmo indivíduo pode compartilhar suas experiências e memória com vários grupos e circuitos culturais. $E$ todas as culturas devem ser reconhecidas mesmo que sob o prisma de seus hibridismos intercambiáveis.

\section{CULTURAS. IDENTIDADES. ENSINO}

De acordo com Burke (2010, p. 22), a amplitude conceitual do termo cultura inclui "quase tudo o que pode ser apreendido em uma dada sociedade", uma vez que o "sistema de significados, atitudes e valores partilhados assim como as formas simbólicas (apresentações, objetos artesanais) em que eles são expressos ou encarnados" (BURKE, 2010, p. 11) relacionam-se aos modos de vida e ao cotidiano - apesar de variarem de sociedade a sociedade e mudarem de um século a outro, o que requer explicação social e histórica.

No que tange ao ensino de Artes, acredita-se que a proximidade com as diversas culturas/civilizações desenha a composição que se inflige à memória e à identidade dos discentes, na repercussão das similaridades diante o próprio tempo social-contemporâneo que lhes é atribuído. Deste modo, acredita-se que a constituição das identidades sociais é fomentada essencialmente na re(a)presentação cultural ao expandirem-se no mundo social através dos alinhavos dos seus respectivos significados narrativos da prática cultural.

Todavia, apesar da aprovação da Lei $n^{\circ} 11.645 / 2008$ que inclui no currículo oficial da rede de ensino a obrigatoriedade da temática "História e Cultura Afro-brasileira e Indígena", percebe-se que os programas curriculares mais específicos de Artes não apontam com frequência - e com veemência - tais conhecimen- 
tos específicos para sua repercussão crítica na prática pedagógica. Nota-se que os conteúdos relativos à descendência nacional e a resquícios da cultura popular, hoje, parecem lembrados apenas como Folclore e em comemoração datadas, como por ocasião do "Dia do Índio" (19 de abril); no "Dia do Folclore" (22 de agosto); ou mesmo no "Dia da Consciência Negra/Zumbi" (em 20 de novembro).

Apesar dos avanços estabelecidos na Constituição de 1988, seguida às leis específicas que deliberam sobre a diversidade cultural no campo educativo, que alteram a Lei de Diretrizes e Bases da Educação Nacional (LDB) para atender ao reconhecimento e valorização da diversidade étnica e cultural, parece que as práticas que reforçam (pre)conceitos e convencionalismos sobre as populações indígenas do país, por exemplo, ainda persistem no espaço escolar. A incorporação da diversidade cultural no currículo, assim como o multiculturalismo e a interculturalidade dos povos indígenas e afro-brasileiros, deve ser compreendida no campo das disputas políticas e ideológicas no qual os vastos debates sociais, muitas vezes, acabam por serem hierarquizados em nossa cultura.

Em se tratando mais pormenorizadamente dos indígenas, assim como em outras culturas, deve-se mencionar que os povos estão em constante transformação cultural. No entanto, o que repercute no ensino - incluindo-se os livros didáticos - é uma perspectiva etnocêntrica, isto é, a ideia de que os indígenas são sociedades desprovidas de tradições que possam ser relevantes na atualidade; como se fossem sociedades congeladas no tempo pelo fato de não mudarem/ não se adaptarem tão velozmente como que nas sociedades ocidentais. É notório que existem signos diversos em suas produções e é inegável que todas estas tenham algum significado espiritual, mitológico ou referente à identidade cultural de suas respectivas tribos/localizações geográficas. Os objetos são produzidos com técnicas passadas de geração a geração para o uso utilitário ou mesmo para cerimônias ritualizadas.

Já em relação à arte africana, no ensino de Artes, podem ser estabelecidas estreitas ligações com o cotidiano e nas diferentes formas de expressão artísticas afro-brasileira onde podem ser consideradas as pinturas corporais, as máscaras, as vestimentas, a estética das oferendas às divindades. A arte que vai do período barroco/colonial até a arte contemporânea, como as esculturas e pinturas, além 
dos objetos, é um referencial importante da cultura afro-brasileira contemplada na historiografia da arte.

Pouco se percebem no ensino institucionalizado as referências alegóricas às atuações indígena/africana na historiografia da arte, por exemplo. Isto é, quais foram os artistas negros representativos na historiografia da arte?; Quais as artistas mulheres notáveis?; Quais ambos resquícios simbólicos e emblemáticos perduram hoje?; ou, como os negros e os africanos foram - e vêm sendo - representados nas linguagens artísticas nacionais?; Enfim, quais figuras e rituais provenientes das culturas e histórias afro e indígena vêm tecendo a história cultural do Brasil fronteiriça à cidadania nacional e à formação identitária da juventude na atualidade?

De acordo com a Base Nacional Comum Curricular / BNCC (2018), que vem balizar competências específicas no ensino de Arte para o ensino fundamental e expansivo ao ensino médio -, é importante que seja desenvolvido na educação básica os seguintes objetivos:

Explorar, conhecer, fruir e analisar criticamente práticas e produções artísticas e cultuais do seu entorno social, dos povos indígenas, das comunidades tradicionais brasileiras e de diversas sociedades, em distintos tempos e espaços, para reconhecer a arte como um fenômeno cultural, histórico, social e sensível a diferentes contextos e dialogas com as diversidades.

Pesquisar e conhecer distintas matrizes estéticas e culturais - especialmente aquelas manifestas na arte e nas culturas que constituem a identidade brasileira -, sua tradição e manifestações contemporâneas, reelaborando-as nas criações em Arte.

Analisar e valorizar o patrimônio artístico nacional e internacional, material e imaterial, com suas histórias e diferentes visões de mundo (BNCC, 2018, p. 198).

Diante este cenário respaldado entre o que determina a Lei (acima mencionada) e o que recomendam as orientações curriculares no ensino de Artes, é imprescindível que o planejamento alcance e propicie aos discentes a interação com a sociodiversidade das culturas indígenas, afro-brasileiras, quilombolas, ciganas e dos demais povos e comunidades tradicionalmente culturais a fim de que sejam compreendidas seus hibridismos e territorialidades socioculturais. Do mesmo modo, é indispensável que aos discentes sejam ofertados subsídios culturais que gerem empatia e respeito referentes aos aspectos políticos, sociais, culturais, étnico-raciais e econômicos na promoção da interação com culturas e saberes de 
distintas manifestações culturais populares presentes também na sua comunidade.

A proximidade com o conhecimento acerca dos acervos dos museus e centros culturais propicia aos discentes, sem dúvida, o exercício da apreciação e da leitura crítica de diversas amostras e expressões artísticas com vistas à valorização das culturas presentes na formação identitária dos muitos grupos de diferentes regiões do Brasil, especialmente as de matrizes indígena e africana. Mesmo em tempos de ensino remoto (devido a pandemia) a visitação dos museus e centros culturais pelos discentes pode ser efetiva para a proximidade com os acervos culturais.

Neste sentido, para que seja possível desenvolver a formação identitária do estudante diante o tema, é preciso que haja uma ambivalência da realidade cultural do estudante diante a re(a)presentação de uma dada civilização cultural - e que esse contato no ensino não seja meramente por meio de uma breve referência, apenas, da ilustração (no livro didático, por exemplo) desprovida de fundamentos culturais que a contextualize. "Não há o brasileiro, o francês, o americano, o japonês. Importa entender como as representações simbólicas dessas nacionalidades são construídas ao longo da história, qual o papel que desempenham nas disputas políticas ou nas formas de distinção sobre o que seria o Outro" (ORTIZ, 2013, p. 622). O ensino de Arte nas suas diversas conexões socioculturais, tem a capacidade de redimensionar e dialogar com a diversidade artística em respeito às idiossincrasias de cada aluno-cidadão.

\section{O RIO POPUlAR DE CULTURA}

Ao estudar sobre cultura popular, há o interesse em pesquisar mais proximamente os acervos de alguns museus localizados na cidade do Rio de Janeiro, tais como o Museu de Folclore Edison Carneiro; o Museu Casa do Pontal; e o Museu Janete Costa de Arte Popular / Niterói. Tais instituições merecem destaque pela notoriedade de suas coleções e a amplitude de seus respectivos acervos de exemplares da arte brasileira. Adiante, segue uma breve sinopse acerca das particularidades de cada um dos museus acima citados. 


\section{MUSEU DE FOLCLORE EDISON CARNEIRO}

Com o término da Segunda Guerra Mundial, a Unesco liderou um movimento que procurou implantar mecanismos para documentar e preservar tradições que estariam em vias de desaparecimento. Foi assim que no Brasil, atendendo a essa diretriz, em 1947 foi criada a Comissão Nacional de Folclore, vinculada à Unesco. Deste processo resultou, em 1958, a instalação da Campanha de Defesa do Folclore Brasileiro, primeiro órgão permanente dedicado a esse campo, vinculado ao então Ministério da Educação e Cultura. Em 1976, a Campanha foi incorporada à Funarte como Instituto Nacional do Folclore. Já com a denominação atual - Centro Nacional de Folclore e Cultura Popular -, a instituição passa, no fim de 2003, a integrar a estrutura do Instituto do Patrimônio Histórico e Artístico Nacional (Iphan).

O então Museu de Folclore Edison Carneiro (Figura 1), criado em 1968 soma, ainda hoje, cerca de 17 mil objetos que constituem tanto a exposição de longa duração "Os objetos e suas narrativas", quanto as exposições temporárias da Galeria Mestre Vitalino. De vários autores, técnicas e procedências, estes objetos estão abrigados em reservas técnicas, disponíveis para consulta de pesquisadores em geral mediante agendamento.

Figura 1 - Museu do Folclore Edison Carneiro

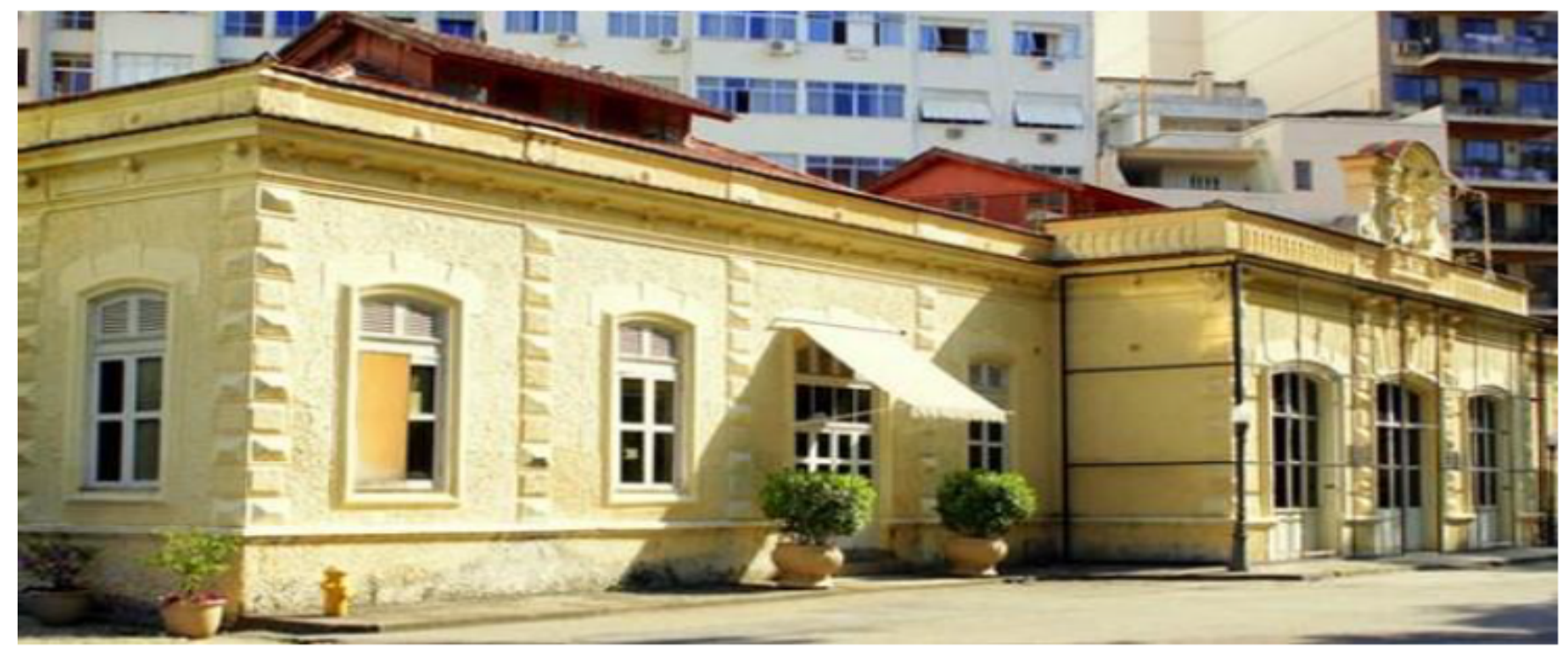

Fonte da autora 
O Centro Nacional de Folclore e Cultura Popular (CNFCP) está instalado no conjunto arquitetônico do Catete, tombado pelo Instituto do Patrimônio Histórico e Artístico Nacional (Iphan). É a única instituição pública federal que desenvolve e executa programas e projetos de estudo, pesquisa, documentação, difusão e fomento de expressões dos saberes e fazeres do povo brasileiro. Suas atividades produziram um acervo museológico de aproximadamente 17 mil objetos, 130 mil documentos bibliográficos e cerca de 70 mil documentos audiovisuais.

O nome do Museu do Folclore foi atribuído a Edison Carneiro (1912-1972). Poeta, escritor, jornalista, tradutor, folclorista, historiador, professor e pesquisador Edison Carneiro forjou-se no campo etnográfico por destacar-se em pesquisas sobre cultura popular e por participar de movimentos que visavam ao conhecimento e valorização do folclore nacional.

\section{MUSEU CASA DO PONTAL}

Figura 2: Museu Casa do Pontal

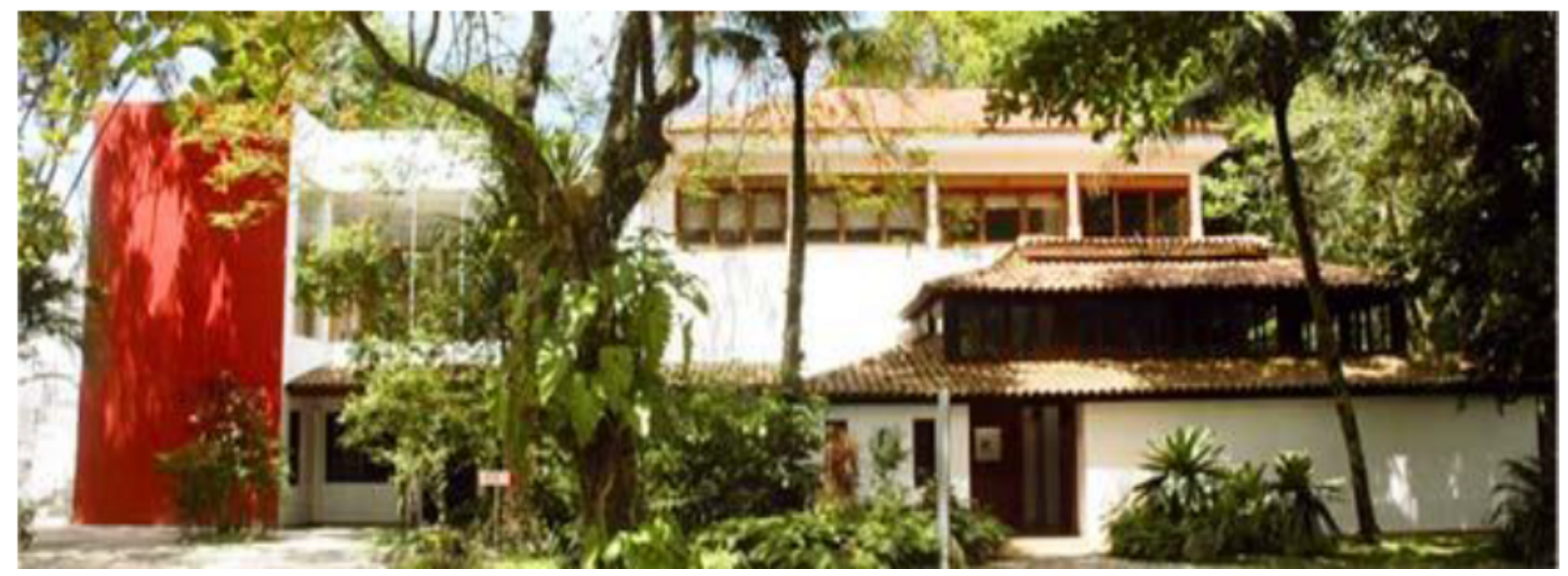

Fonte: www.museucasadopontal.com.br

Situado na zona oeste carioca, o Museu Casa do Pontal (Figura 2) é considerado o maior e mais significativo museu de arte popular do país. E é o resultado de 40 anos de pesquisas e viagens por todo país do designer francês Jacques Van de Beuque. O nome casa se coloca como uma referência à sua experiência de intimidade com os artistas e a arte popular; e evoca, sem dúvida, a afetividade que o espaço mantém com o seu público. 
Como missão, o Museu Casa do Pontal prima pela memória, reconhecimento e valorização da arte popular brasileira através de atividades de pesquisa, preservação e divulgação ampla de seu acervo de grande representatividade no Brasil.

Seu acervo é composto por cerca de 8.500 peças de 300 artistas brasileiros, produzidas a partir do século XX. A exposição permanente do Museu reúne, em $1.500 \mathrm{~m}^{2}$ de galerias, obras representativas das variadas culturas rurais e urbanas do Brasil. O acervo do museu é distribuído de modo temático e destaca as atividades cotidianas, festivas, imaginárias e religiosas.

A coleção de Jacques Van de Beuque é constituída basicamente por esculturas, máscaras e placas que descobriu ao viajar pelo Brasil, predominantemente na região nordeste. A maior parte do acervo é composto de peças feitas em barro, cozido ou cru, que representam, em miniaturas ou grandes formas, festas folclóricas, crenças, costumes, tradições, rituais ou o imaginário. Também há uma expressiva coleção de obras feitas em madeira e, outras, de menor porte, que utilizam como matéria-prima materiais diversos como a areia, o ferro, o papel machê, o tecido e muitos outros. Destacam-se, ainda, as coleções de arte sacra, com a representação católica de santos, anjos, festas religiosas e presépios. Em menor proporção, encontra-se a representação de entidades sagradas afro-brasileiras, da umbanda e do candomblé, e de alguns elementos presentes em seus cerimoniais como o transe, o despacho, as oferendas e as ferramentas dos orixás. Os ex-votos são numerosos no acervo e, na sua maior parte, provêm de Canindé, no Ceará. Algumas carrancas originárias do Rio São Francisco integram o conjunto que se completa com geringonças, torés e grandes instalações articuladas mecanicamente. 


\section{MUSEU JANETE COSTA DE ARTE POPULAR / NITERÓI}

Figura 3: Museu Janete Costa de Arte Popular

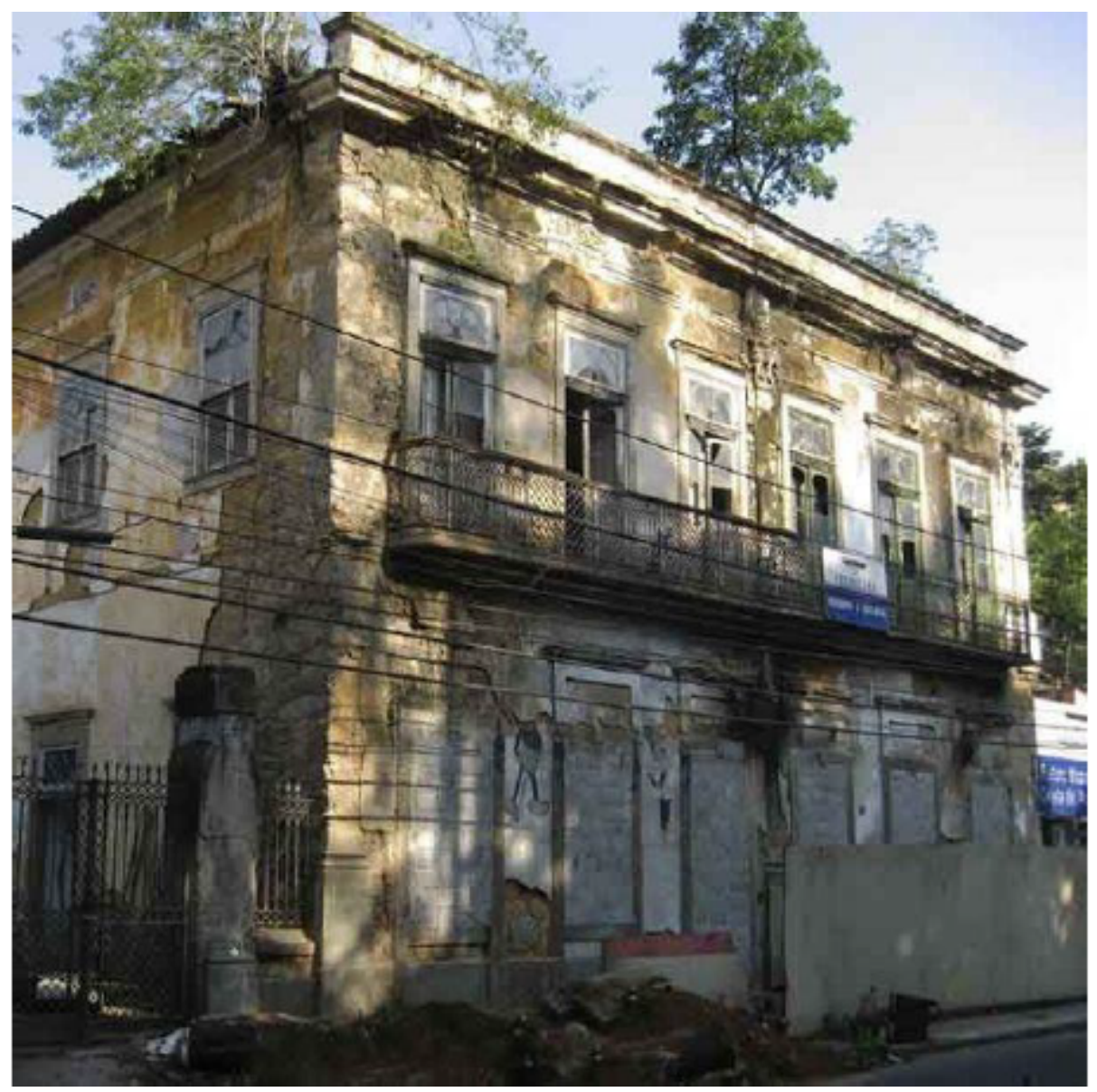

Fonte: www.culturaniteroi.com.br/janete/

O Museu Janete Costa de Arte Popular (Figura 3) tem o objetivo de ampliar a divulgação da cultura popular brasileira. Situado em dois sobrados do século XIX, com fachadas tipicamente neoclássicas, o Museu é localizado na cidade de Niterói - no bairro do Ingá. O Museu abriga o nome de uma das maiores pesquisadoras e especialistas em arte popular brasileira, Janete Costa - que viveu parte de sua vida na cidade fluminense. A reforma dos imóveis e restauração da fachada tombada, ficaram a cargo do filho Mario Costa Santos.

Inaugurado no dia 28 de novembro de 2012 (data em que se completou quatro anos do falecimento de Janete Costa), o Museu de Arte Popular abrigou a exposição “Janete Costa - Um Olhar", cujo curador, Mario Santos (filho de Janete), teve o objetivo de proporcionar (como mencionado no site do Museu) aos espectadores "um passeio pelo Brasil e sua diversidade, uma explosão criativa exposta 
num labirinto de obras de arte, onde cada peça surpreende e revela regionalidade, expressando a cultura e brasilidade". Sem fazer distinção das diferentes classificações dentro do mundo das artes, Janete Costa (como mencionado no site do Museu) admirava a arte em si e afirmava que "para entender a arte é preciso aprender a olhá-la". E foi com esta crença que a própria Janete sugeriu a ideia da construção de um museu de arte popular.

\section{(EM PROCESSO DE) CONCLUSÃO}

O insuficiente apoio institucional, a informação/o conhecimento reduzidos (ou anulados) nos materiais didáticos e a formação inicial/continuada insuficientes que se atribuem aos docentes no que tange à cultura (como conceito) e ao popular (como temática), resultam no quanto ainda falta avançar para uma efetiva implementação da Lei no $11.645 / 2008$ no ensino escolar de Artes. É urgente a atualização da abrangência dos conceitos predominantes na historiografia da arte, em especial, que se apresentam como fundamentais para uma prática pedagógica respeitosa à diversidade no que se refere à cultura, identidade, etnocentrismo e relações interétnicas - dentre outros.

O que se vê de modo recorrente são programas curriculares e livros didáticos conteudistas, em sua grande maioria com uma visão eurocêntrica e predominantemente "branca" da história de nosso país, perpetuando aos discentes um fluxo intenso de estereótipos, preconceitos e histórias muito distantes da nossa real representatividade étnica. Tais manuais de apoio metodológico para docentes, de fato, não contemplam ativamente os enredos de nossa herança cultural em respeito aos legados culturais indígenas e africanos, como se viu. Acredita-se que o contato presencial dos docentes e discentes ao Rio popular de cultura nos museus e centros culturais é um caminho de aproximação com as especificidades culturais que rondam suas próprias histórias (e estórias). As práticas de significação e os hibridismos dos sistemas simbólicos atuam na constituição epistemológica do sujeito-indivíduo e do sujeito coletivo - na mesma medida em que atuam na identidade-subjetividade cidadã. Essa sujeição é responsável pela produção das diferenças, que são intrínsecas à constituição das identidades, regulando os sujeitos e suas condutas. 
De certo, o currículo de Arte está centrado na interseção das narrativas cotidianas entre a escola e a cultura - em via de mão dupla. Pensar o currículo escolar na perspectiva da cultura pode ser um dos percursos positivos para o ensino das Artes e para a formação identitária discente.

\section{REFERÊNCIAS}

BRASIL. Constituição (1988). Constituição da República Federativa do Brasil. Brasília, DF, Senado Federal: Centro Gráfico, 1988.

BRASIL. Lei $n^{\circ} 11.645$, de 10 de março de 2008. Diário Oficial da União, Brasília, 11 de março de 2008. Disponível em <http://www.planalto.gov.br/ccivil_03/_ ato2007-2010/2008/lei//11645.htm>.

BRASIL. Ministério da Educação. Base Nacional Comum Curricular - BNCC. Brasília, DF, 2018.

BURKE, Peter. O que é história cultural? (Trad. Sérgio G. de Paula). Rio de Janeiro: Jorge Zahar, 2005.

BURKE, Peter. Cultura Popular na Idade Moderna. São Paulo: Companhia das Letras, 1989.

CANCLINI. Néstor García. Culturas Híbridas: estratégias para entrar e sair da modernidade. São Paulo: Editora da Universidade de São Paulo, 2015.

CERTEAU, Michel de. A cultura no plural. Campinas, São Paulo: Papirus, 1995.

CHARTIER, Roger. Cultura Popular: revisitando um conceito historiográfico In Revista Estudos Históricos. Rio de Janeiro: Fundação Getúlio Vargas, vol. 8, n.16, 1995, p. 179-180.

CHAUÍ, Marilena. Conformismo e resistência: aspectos da cultura popular no Brasil. São Paulo: Brasiliense, 1986.

DA MATTA, Roberto. Relativizando: Uma Introdução à Antropologia Social. Petrópolis: Editora Vozes, 1981.

EAGLETON, Terry. A ideia de cultura. Lisboa: Temas e Debates, 2000. 
FROTA, Lélia Coelho. Arte do povo. 1976.

Disponível em www.museucasadopontal.com.br Acesso: 10/05/2020.

GEERTZ, Clifford. A interpretação das culturas. Rio de Janeiro: LTC, 2008.

HALL, Stuart. A centralidade da cultura: notas sobre as revoluções culturais do nosso tempo. In Educação e Realidade. Porto Alegre, n² 2, vol 22, 1997.

HALL, Stuart. A identidade cultural na pós-modernidade. Rio de Janeiro: Lamparina, 2019, $12^{\mathrm{a}}$ ed.

LARAIA, Roque. Cultura: um conceito antropológico. 19. ed. Rio de Janeiro: Jorge Zahar, 2006.

MASCELANI, Ângela. Casa do Pontal e suas coleções de arte popular brasileira. In Revista do Patrimônio Histórico e Artístico Nacional, $n^{\circ} 28$. Rio de Janeiro: IPHAN, 1999.

MINTZ, Sidney. Cultura: uma visão antropológica. In Tempo [online], 2010, vol $14, n^{\circ} 28$, pp. 223-237.

MOREIRA, Antônio Flávio Barbosa; CANDAU, Vera Maria. Educação escolar e cultura(s): construindo caminhos. In Revista Brasileira de Educação. São Paulo, n. 23, p. 156-168, 2003.

VEIGA-NETO, Alfredo. Currículo, cultura e sociedade. In Educação Unisinos. Porto Alegre, v. 8, n. ${ }^{\circ} 15$, p. 157-171, 2004.

ORTIZ, Renato. Cultura brasileira e identidade nacional. 2a ed. São Paulo: Brasiliense, 1986.

ORTIZ, Renato. Imagens do Brasil. In Revista Sociedade e Estado, vol 28, № 3 , 2013.

SILVA, Tomaz Tadeu. Teorias do Currículo: uma introdução crítica. Porto, Portugal: Editora Porto, 2000.

THOMPSON, John. Ideologia e cultura moderna. Teoria social crítica na era dos meios de comunicação de massa. Petrópolis: Vozes, 2009. 
VELHO, Gilberto. Cultura popular e sociedade de massas: uma reflexão antropológica. In Piracema Revista de Arte e Cultura. Rio de Janeiro: Instituto Brasileiro de Arte e Cultura - MEC, 1993.

\section{Sites}

Museu Casa do Pontal

http://www.museucasadopontal.com.br

Museu do Folclore Edison Carneiro

http://www.cnfcp.gov.br/interna.php?ID_Secao=2

Museu Janete Costa de Arte Popular

http://culturaniteroi.com.br 


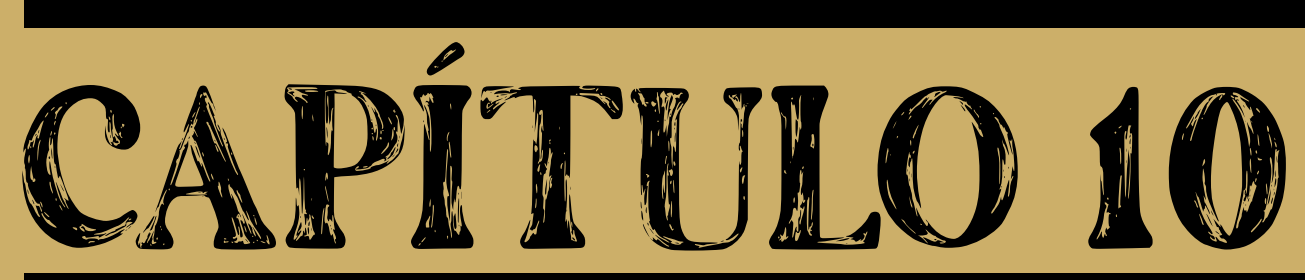

\section{FUNDAMENTOS TEÓRICOS DA COR E A PRÁXIS ARTÍSTICA NO ENSINO TÉCNICO INTEGRADO EM QUÍMICA INDUSTRIAL}

Silvana dos Passos Silva ${ }^{1}$ Ana Luiza Ruschel Nunes ${ }^{2}$

1 Artista Plástica; Professora de Arte na Rede Estadual de Ensino do Paraná; Graduação em Licenciatura em Artes Visuais- UEPG; Especialização em História Arte e Cultura; Especialização em Arte Educação; Mestranda em Educação- UEPG. Email: sps.silvana@gmail.com

2 Professora doutora atua no mestrado e doutorado do Programa de Pós-Graduação em Educação, no Departamento de Artes e no Curso de Graduação em Artes Visuais, UEPG. Graduada em Educação Artística (1976) e Artes Plásticas pela Universidade Federal de Santa Maria/RS (1981); Mestrado em Educação- UFSM; Doutorado em Educação- UNICAMP/SP; Pós-Doutorado- UESC/SC. Email: analuizaruschel@gmail.com 


\section{INTRODUÇÃo}

No mundo contemporâneo as linguagens visuais ampliam-se cada vez mais. E reconhecendo que vivemos inundados de uma extraordinária variedade de imagens percebidas através da cor, podemos dizer que a cor é importante e quase que indispensável ao homem, para que conheça e reconheça o mundo que o rodeia.

Hoje a cor não se configura simplesmente como elemento estético, ela é responsável também pelas atitudes das pessoas e desencadeia fenômenos psicológicos. A busca de novas propostas de cor é contínua, além de um fenômeno físico, químico e fisiológico, ela também é cultural.

O tema cor alia várias áreas do conhecimento como a física, a química, a comunicação, que interconectada com as Artes Visuais, exige do futuro professor subsídios teóricos e práticos num trabalho interdisciplinar.

Em sintonia com o explicitado acima e a partir da valorização do estudo da cor, organizou-se a presente pesquisa distribuída em referencial teórico sobre a Teoria da Cor optando-se pela Teoria da cor de Paul Klee, a partir da autora Lilian Ried Miller Barros e Teoria da cor a partir de Israel Pedrosa para dar subsídios e fundamento a pesquisa com alunos do ensino técnico integrado em química, referente aos seus conhecimentos, bem como o aprofundamento da temática cor, entendendo que para esses alunos o entendimento do fenômeno cor é de extrema importância.

Esta investigação teve por base uma abordagem qualitativa através de um estudo de caso com produção de um multimídia sobre a teoria da cor de Paul Klee da temática cor

O trabalho apresenta o processo e análise dos resultados de uma prática educativa em Artes Visuais, tendo como investigação a questão da aprendizagem sobre o conhecimento cor em sua complexidade artística, educacional e cultural.

Por fim, pontua-se as considerações finais sobre a pesquisa, trazendo algumas questões de reflexão e possíveis avanços investigativos em relação à temática. 


\section{TEORIA DA COR DE PAUL KLEE: FUNDAMENTOS PARA $O$ CONHECIMENTO COR E PRODUÇÃO ARTÍSTICA}

Todas as abordagens da cor desde os pintores gregos aos pintores medievais, não chegam constituir uma teoria, somente no Renascimento com Leonardo da Vinci é que teremos uma teoria da cor (PEDROSA, 1982).

Ao definir a iluminação dos corpos, Da Vinci diz que todos os corpos se revestem de luzes e sombras, e a luz se divide em original e derivada. Mas, como afirma Pedrosa, para o pintor da época o campo palpável era o da química, no manuseio de pigmentos, aglutinantes, fixadores e vernizes na produção de tintas. Para Da Vinci existiam quatro cores simples: amarelo, vermelho, verde e o azul. O branco era síntese de todas as cores e o preto a ausência da luz (PEDROSA, 2006).

A descoberta da cor do ar faz parte das deduções experimentais do Renascimento. Esta descoberta descrita por Leonardo, que a cor do ar é azul, sendo mais ou menos escuro dependendo da umidade, é a base para a teoria da perspectiva aérea.

Englobando a perspectiva aérea e a linear, surge para Leonardo a perspectiva pictórica e a divide em três partes: diminuição quantitativa dos corpos; atenuação de suas cores; e a diminuição das figuras e dos contornos a diversas distâncias. À longa distância, os objetos trocam de cor devido à ação do ar entreposto aos objetos e o olho do observador.

O suíço Paul Klee foi músico, poeta, artista plástico e mestre da Universidade de Bauhaus, onde desenvolveu sua teoria elementar da criação, bem como sua teoria da cor. A teoria da cor de Paul Klee segundo Barros (2006) está extremamente vinculada a sua teoria da forma.

O artista Paul Klee não tinha formação de pedagogo, e isso o levou a elaborar um sistema teórico para sua atividade docente a partir de sua experiência artística, traduzindo em esquemas e palavras suas conquistas intuitivas. Enquanto mestre, Paul Klee não estabelecia normas a serem seguidas, mas incentivava seus alunos a percorrerem seus próprios caminhos interpretativos na direção de suas descobertas. A concepção pedagógica de Klee se espelhará na concepção da arte (BARROS,2006). 
Klee convida seus alunos a uma viagem por pensamento que conduz do arco-íris ao círculo cromático. O arco-íris para ele é apenas uma representação linear das sete cores e finito, e diz que estas cores na natureza, quando decodificadas pela nossa visão e sintetizada no círculo cromático, atingimos o verdadeiro conceito cósmico das cores puras, expresso pelo movimento de rotação completo e infinito. Paul Klee dá grande importância ao círculo cromático, interpretando-o como a mais pura forma de movimento (BARROS, 2006).

Tendo o arco-íris como ponto de partida para abordagem das cores, Klee considera-o como o símbolo de todo o uso da cor por ele não se encontrar na atmosfera e nem na terra, e sim entre o domínio terrestre e o cosmos. Segundo Klee, o arco-íris é composto por sete cores e ao unir os dois extremos do arco-íris, Klee faz a representação linear das cores, fazendo surgir da união das duas últimas cores visíveis do arco-íris, o violeta e o azul-índigo, uma única cor violeta. Assim, as sete cores do arco-íris tornam-se seis e esta união se fecha no círculo cromático (BARROS, 2006).

O círculo cromático para Klee tem movimento. O movimento periférico das misturas de tons análogos se faz infinito em sentido horário, o movimento diametral das complementares, que se dá pela cor primária em direção a cor oposta no círculo cromático ou vice-versa. Estas cores formam pares de cor que Klee chama de pares de cor verdadeiros, isto porque a partir de suas misturas resulta o cinza neutro e denomina de falsos pares de cor as cores cujas misturas não resultam no cinza neutro. Portanto, as cores complementares são pares de cor verdadeiros (vermelho e verde; azul e laranja; amarelo e violeta). Estas cores se ligam no círculo cromático por uma linha diametral passando pelo centro, onde fica o cinza neutro, e para Klee este movimento é pendular, devido ao fenômeno que acontece na retina, de uma cor chamar a outra. Já os pares falsos de cor têm um movimento que não passa pelo centro do círculo e por isso sua mistura resulta sempre em um cinza colorido e não neutro.

O movimento periférico das cores no círculo é chamado de cânone da totalidade cromática e é composto pelas cores primárias vermelho, amarelo e azul em movimento periférico e infinito. 
No círculo cromático as cores primárias têm um limite, apenas quando uma cor está na sua máxima intensidade é que está ausente da influência das outras. Paul Klee representa o cânone da totalidade cromática num modelo cósmico, tendo as cores primárias em órbita ao redor de uma esfera cinza, acima uma esfera branca e abaixo uma esfera preta.

Para enfatizar o caráter dominante das cores primárias, Klee insere um triângulo dentro de um círculo onde seus vértices apontam para cada uma das primárias situadas no círculo, distinguindo os movimentos complementares e componentes que parte das cores primárias para as secundárias (ver figura 1).

Figura 1 - Movimentos Complementares
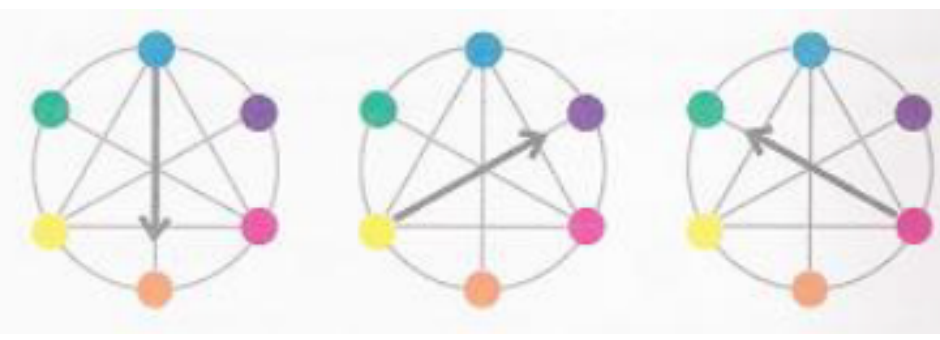

Fonte: Lílian Ried Miller Barros. "A cor no processo criativo", editora Senac-SP, São Paulo: 2006, p.138, fig.35

Nos falsos pares, amarelo e verde, o gráfico mostra que o verde está fora do triângulo, o mesmo acontece como os falsos pares, azul e violeta, e vermelho e laranja (ver figura 2). No desmembramento de um falso par de cores, teremos um excesso de cor, por exemplo: verde e laranja (pares falsos). Desmembrando o verde, teremos o amarelo e o azul, desmembrando o laranja, teremos o amarelo e o vermelho. Portanto, com os desmembramentos teremos um excesso de amarelo.

Figura 2- Movimentos Componentes
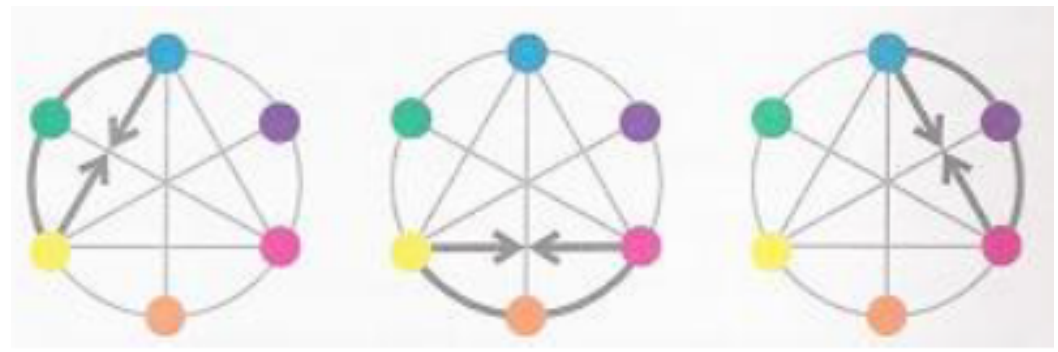

Fonte: Lílian Ried Miller Barros. "A cor no processo criativo", editora Senac-SP, São Paulo: 2006, p.138, fig.35 
Recorrendo a esfera de Phillipe Otto Runge, Klee engloba toda a geografia da cor numa síntese tridimensional. A esfera contendo a cor branca no polo norte, o preto no polo sul, as cores primárias, secundárias, terciárias e demais componentes destas cores se situam na linha do equador e o cinza neutro no centro da esfera. Nela se tem a topografia das cores e podemos visualizar três movimentos. Abaixo (ver figura 3), tendo a cor vermelha como exemplo, se destacam: o movimento periférico em direção as cores azul e amarelo, o diametral em direção ao verde e o movimento polar em direção ao branco ou ao preto, bem como, o movimento de pares das cores complementares.

Figura 3- Os três movimentos cromáticos

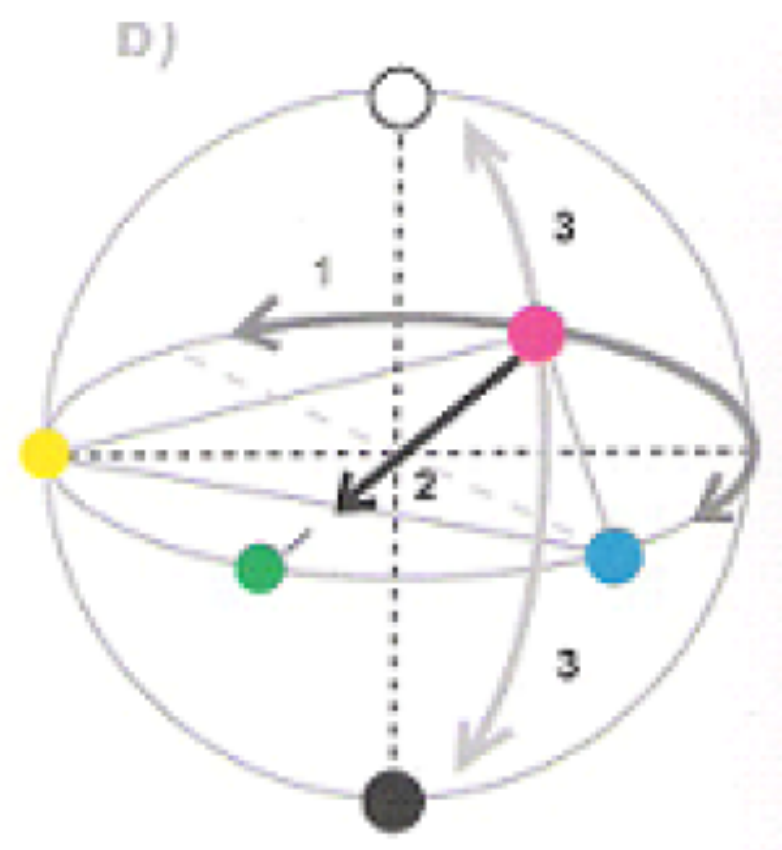

Fonte: Lílian Ried Miller Barros "A cor no processo criativo", editora Senac-SP, São Paulo: 2006, p. 144, fig. 40

Paul Klee recorreu à esfera cromática de Phillipe Otto Runge, para a representação da visualização das misturas entre os matizes, tons de cinza e os contrastes de claro-escuro, sintetizando tridimensionalmente as cores ( ver figura 4) 
Figura 4 - A esfera cromática em três dimensões

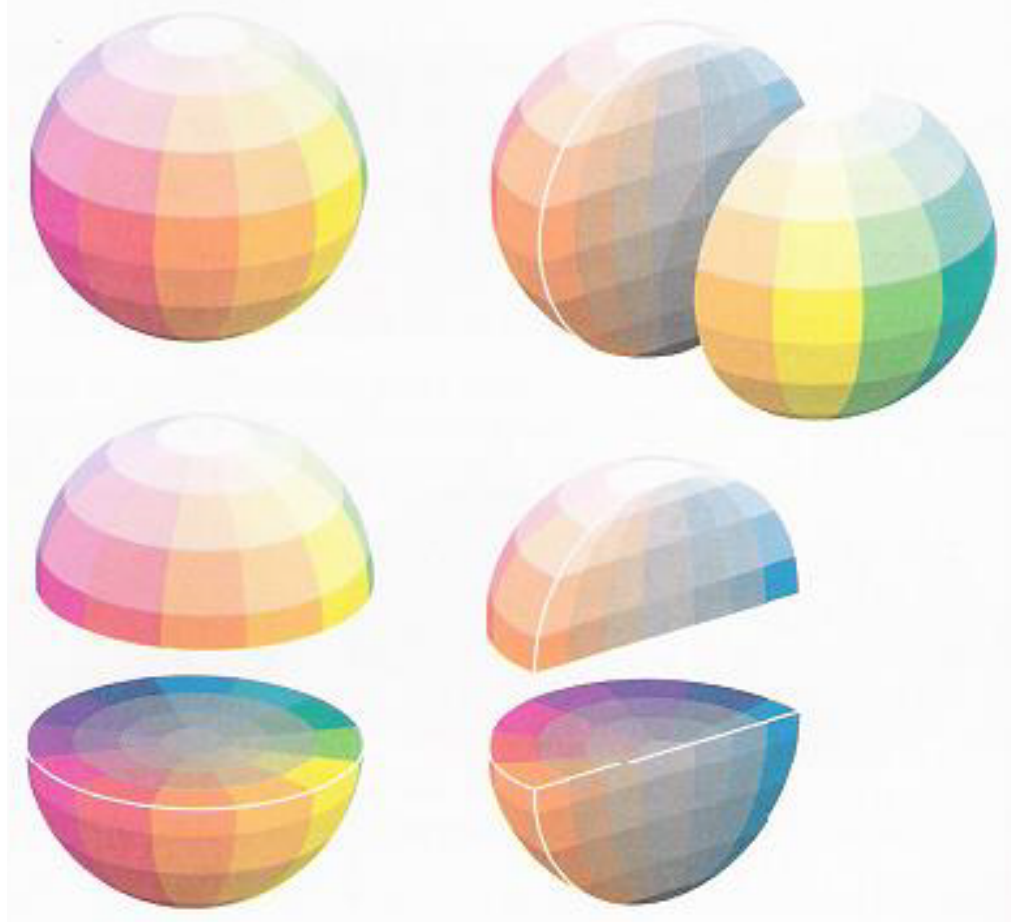

Fonte: Lílian Ried Miller Barros "A cor no processo criativo", editora Senac-SP, São Paulo: 2006 , p.102 fig. 16

\section{CONCEPÇÃO DE ARTE E EDUCAÇÃO: UMA INVESTIGAÇÃO NO ENSINO TÉCNICO EM QUÍMICA INDUSTRIAL.}

A concepção de Arte do ponto de vista científico é a expressão legítima de um tipo de personalidade mental, mas também, é um meio de expressão comum à cultura de todas as épocas, envolvendo princípios como o da forma, que é uma função da percepção e o da criação que é a imaginação, estas duas atividades unem todos os aspectos psíquicos da experiência estética (SOUZA, 1974). Já a concepção de Educação numa sociedade onde a democracia impera se resume na individualidade de cada ser humano paralelamente com sua consciência ou reciprocidade social. Portanto, segundo Souza (1974, pág.55) "educado será aquele que realize plenamente sua individualidade, dentro da totalidade orgânica da sociedade que pertence".

$\mathrm{Na}$ disciplina de arte e desvendando o conhecimento Cor por parte de alunos do ensino médio do curso técnico integrado em química, voltou-se para uma 
investigação de forma participativa a partir de um estudo de caso.

De acordo com a Lei de Diretrizes e Bases, LDB, o ensino médio tem como objetivo a consolidação e o aprofundamento dos conhecimentos adquiridos no ensino fundamental, possibilitando o prosseguimento dos estudos, isto é, cabe ao ensino médio a preparação para o trabalho e a cidadania do educando (PENNA, 2003).

O ensino médio integrado é baseado nos princípios da contextualidade, interdisciplinaridade e flexibilidade. A base curricular é composta por componentes curriculares que possibilitam a construção de conhecimentos e contemplam a formação integral do jovem em consonância com as necessidades do mundo do trabalho.

A interdisciplinaridade, nas suas mais variadas formas, parte do princípio, de que todo conhecimento, mantém um diálogo permanente com outro conhecimento. $O$ ensino deve ir além da descrição e procurar constituir nos alunos a capacidade de analisar, explicar, prever e intervir objetivos, que são mais facilmente alcançáveis se as disciplinas, integradas em áreas de conhecimento puderem contribuir cada qual na sua especificidade para o estudo comum de problemas concretos, ou para o desenvolvimento de projetos de investigação e/ou de ação.

O Colégio João Ricardo Von Borel du Vernay contexto da pesquisa, traz em seu espaço a formação técnica Integrada em Química Industrial, aliando na formação do jovem, sua relação entre ensino e indústria, o que destacamos tratar do conhecimento cor, pois esse, alarga para outros campos do conhecimento como Química, Física, Químico-física, além de aprofundar a cor para o processo pictórico em que hoje são conhecimentos da arte presente dentro da fábrica e da indústria contribuindo para a qualidade de vida do trabalhador.

Neste sentido enfatiza Nunes (2004, pág. 202) em relação ao trabalho e educação:

É preciso ter clareza da concepção de trabalho sem dissociá-lo da práxis educativa, como categoria fundamental, portanto, para ser retomado pelos educadores que se propõem a construir a educação que instrumentalize o educando a ler criticamente o seu universo histórico vivido e suas contradições, produzindo uma postura dialética diante da vida, vinculando com 
a formação humana contínua, privilegiando um corpo de conhecimentos, oportunizando a apreensão do melhor da cultura artística produzida universalmente e acumulada pela humanidade.

A pesquisa se desenvolveu em três momentos, sendo que o primeiro foi de caráter bibliográfico e exploratório, fazendo um estudo da realidade escolar através de observações em sala de aula de Artes Visuais e da literatura pertinente ao tema da pesquisa, bem como o contato com os participantes da pesquisa ligados ao fenômeno em estudo da investigação e do pensamento ainda especulativo da pesquisadora em relação ao tema e seu contexto, pois se a finalidade do estudo de caso é retratar uma unidade em ação, a pesquisadora em sua investigação precisava superar a visão especulativa para a de pesquisa científica.

O segundo momento foi a delimitação do estudo e destaque das problematizações ou questões de pesquisa, para posteriormente proceder a coleta dos dados, tendo em vista o tema e os problemas. A partir de um questionário semiestruturado para compreender os diversos pontos de vista acerca da realidade dos alunos em relação ao fenômeno cor e suas concepções, bem como pelo conhecimento da teoria da cor de Paul Klee, o questionário serviu para obter informações subjetivas e objetivas contidas nas falas dos participantes, feitas individualmente e coletivamente no processo de interação da ação educativa observada pela pesquisadora.

Referente à temática, o questionário constava de oito perguntas sobre o fenômeno cor. Estas respostas serviram de ponto de partida para o início da pesquisa e o desenvolvimento do ensino cor na disciplina de Artes Visuais.

A investigação da prática dos alunos referente ao volume, dado pela luz e sombra, veio da representação de uma forma cilíndrica sobre a mesa e iluminado por uma lâmpada por um dos lados (ver figura 5 e 6 ). A pintura foi realizada com pigmento natural, todas as pinturas foram analisadas pela turma e algumas foram selecionadas, fotografadas e anexadas aos resultados da pesquisa, como segue o exemplo. 
Figura 05 - Pintura de observação com pigmento natural- Luz e sombra Alunos do $1^{\circ}$ ano do Curso Técnico em Química

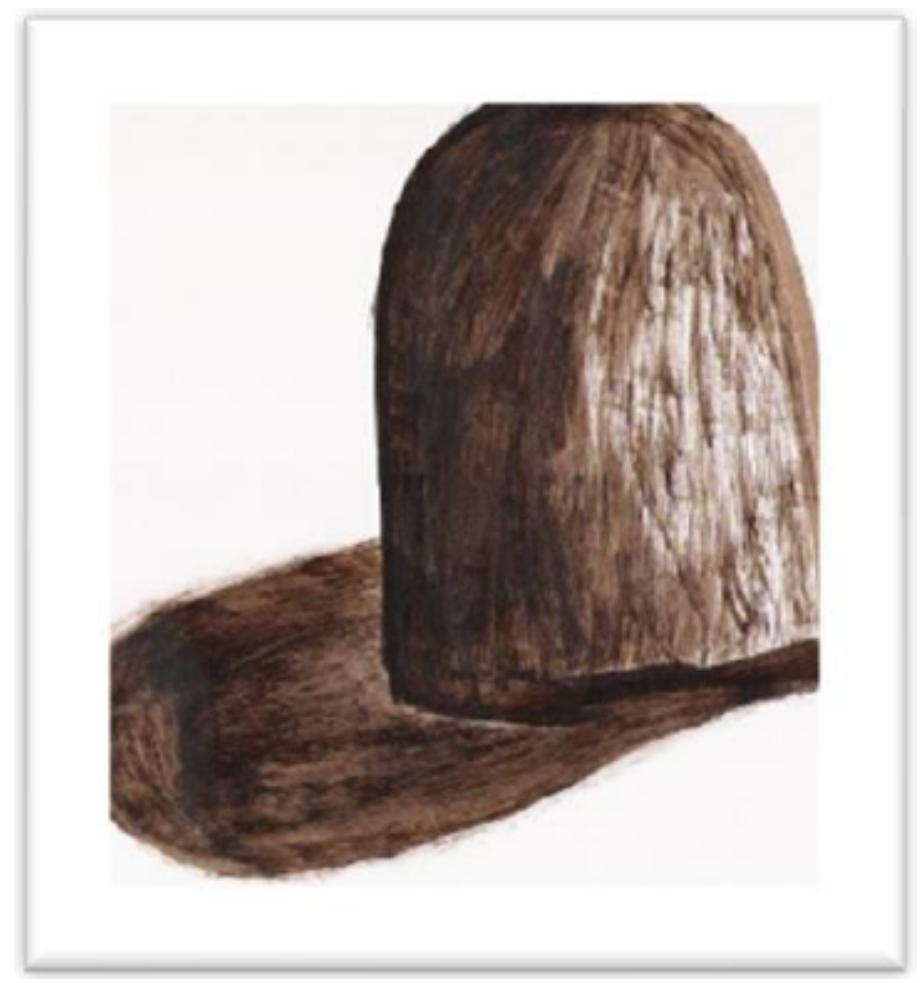

Fonte: As autoras

Figura 06- Pintura de observação com pigmento natural- Luz e sombra Alunos do $1^{\circ}$ ano do Curso Técnico em Química

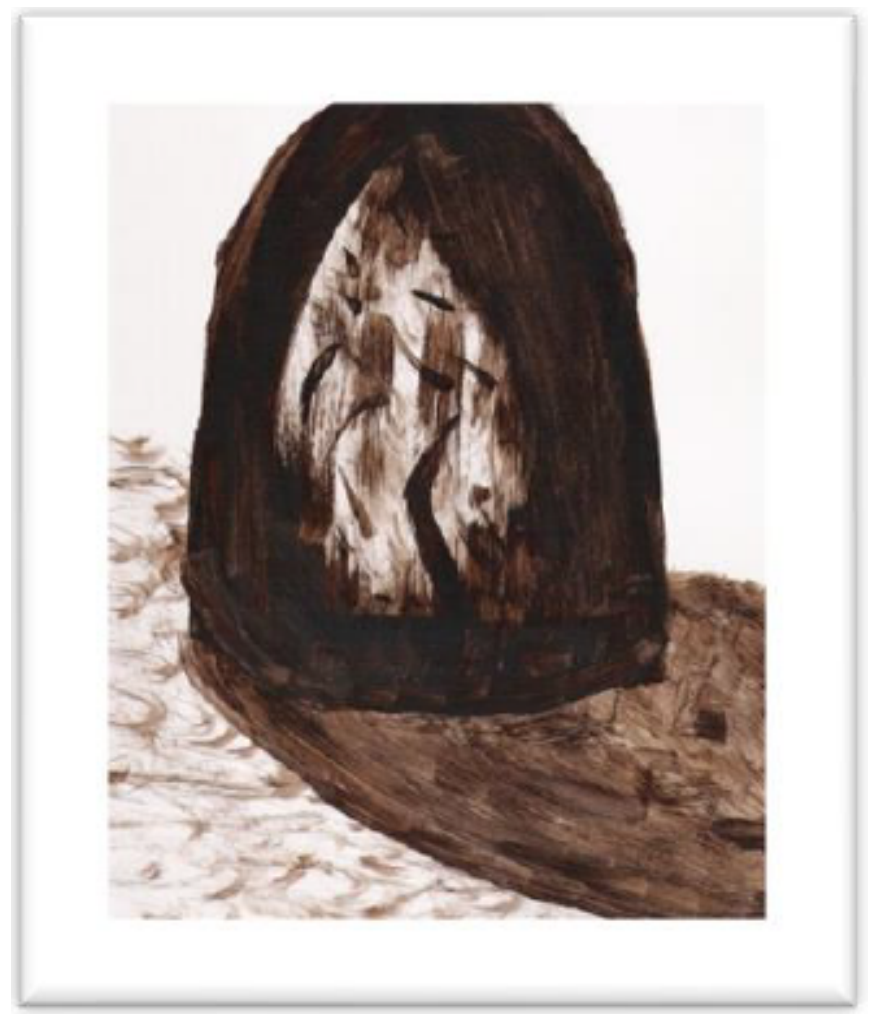

Fonte: As autoras 


\section{O PROCESSO CRIATIVO DA PRÁtICA ARTística PICTÓRICA COM BASE NA TEORIA DE PAUL KLEE}

O processo investigativo constou também de uma leitura de imagem, enfocando a questão cor na obra de arte. Os alunos dividiram-se em sete grupos, com média de cinco alunos cada. Foram disponibilizados quinze folders, com obras de artistas de vários períodos da História da Arte, sendo que cada folder constava de três imagens de diferentes obras desse autor (ver figura 7).

Figura 7- Momento da leitura de Imagem Col. Prof. João Ricardo Von Borell du Vernay

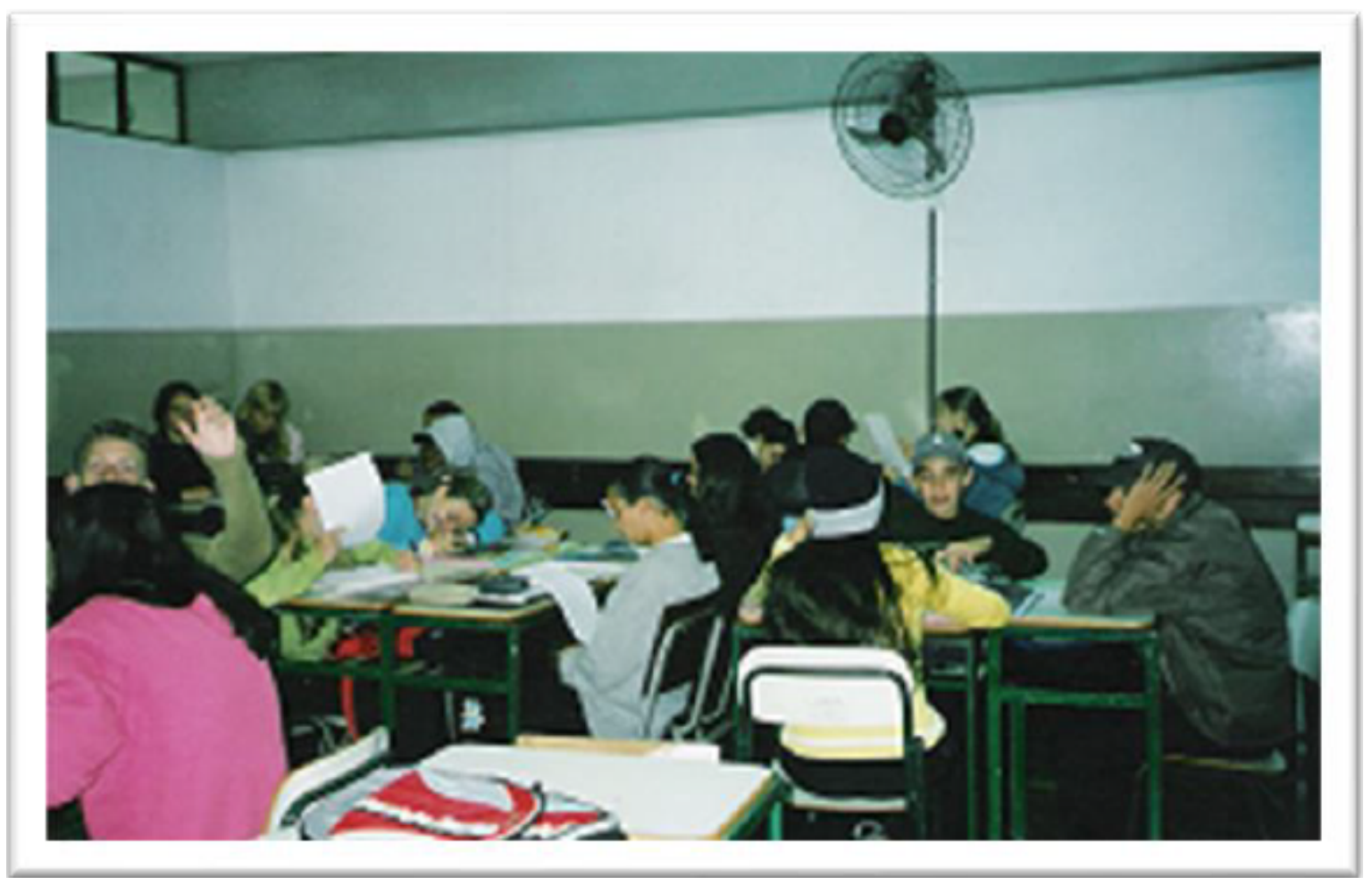

Fonte: As autoras

Com a investigação do material de apoio produzido pela pesquisadora, que consta de um multimídia a partir de gráficos da Teoria de Paul Klee do livro "A cor no Processo criativo: Um estudo sobre a Bauhaus a teoria de Goethe" de autoria de Lílian Ried Miller Barros, fez-se um DVD de animação, tornando os gráficos impressos em imagens dinâmicas, a partir de programas como: Macromédia Flash 8; Blender 3D 4.23; Audacity 1.2.0; Nero Vision 4 e Nero ultra 7 sob a colaboração do técnico em informática e orientação da Profa Dra Ana Luiza Ruschel Nunes. $O$ 
material consta de um DVD com duração de 9,53 min, apresentando legendas e áudio. Esta experiência, constou da apresentação do multimídia, juntamente com a explanação e explicação da Teoria da cor de Paul Klee, o qual proporcionou o conhecimento e o enriquecimento aos alunos, sobre esta teoria da cor da qual não conheciam (ver figura 8).

Figura 8- Apresentação do DVD sobre a Teoria da Cor de Paul Klee

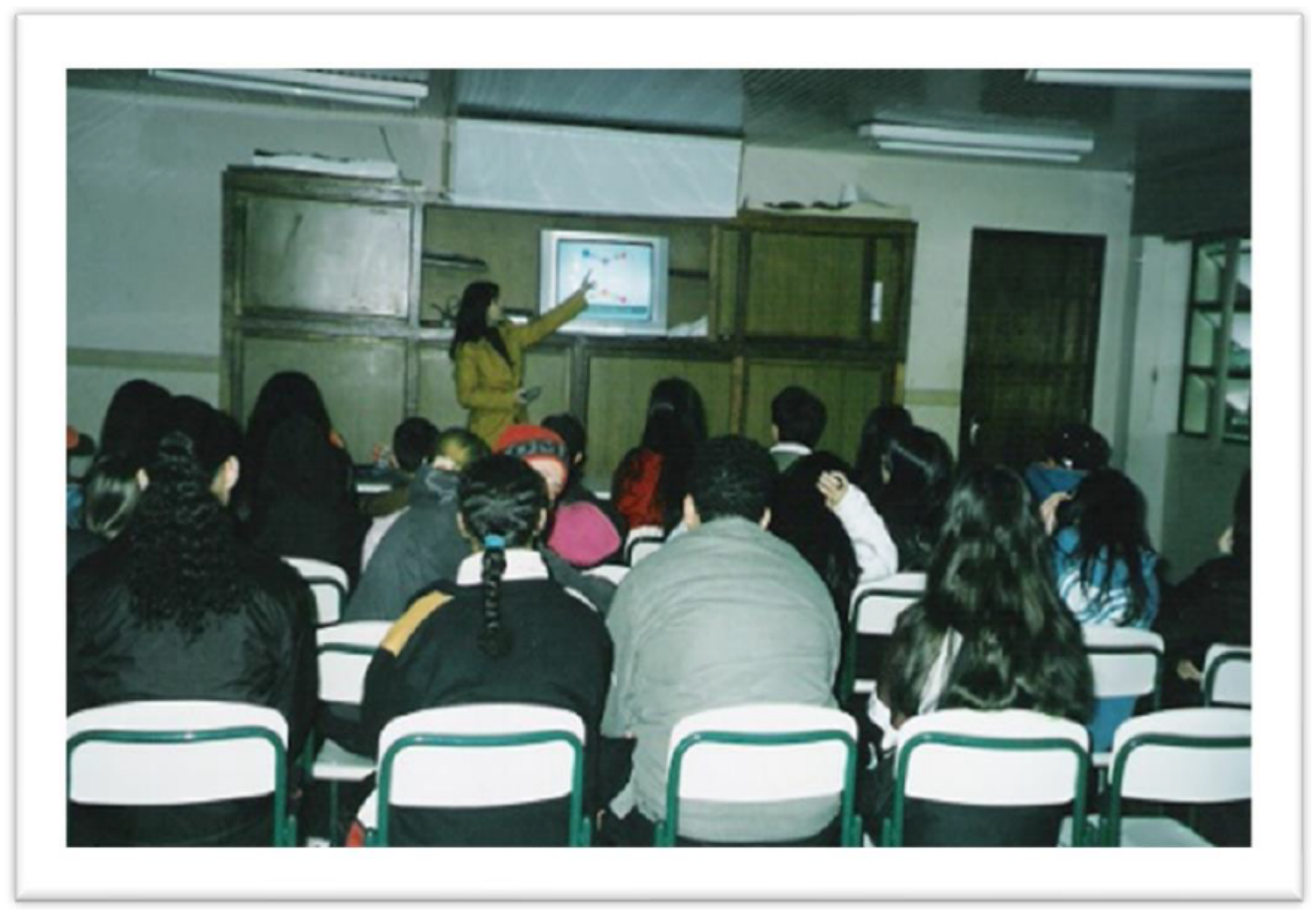

Fonte: As autoras

Aplicando esta teoria e os demais conhecimentos trabalhados, (ver figuras $9,10,11$ ) foi realizada a produção das poéticas pelos alunos. Para esta produção foi escolhido um material que fazia relação à esfera cromática de Philipp Otto Runge. O suporte foi uma esfera de isopor de $20 \mathrm{~cm}$, a qual os alunos teriam por objetivo realizar uma pintura, envolvendo questões cromáticas com os conhecimentos trabalhados e adquiridos durante o percurso desta investigação sobre a cor. 
Figuras 09- Momento da produção de pinturas pelos alunos

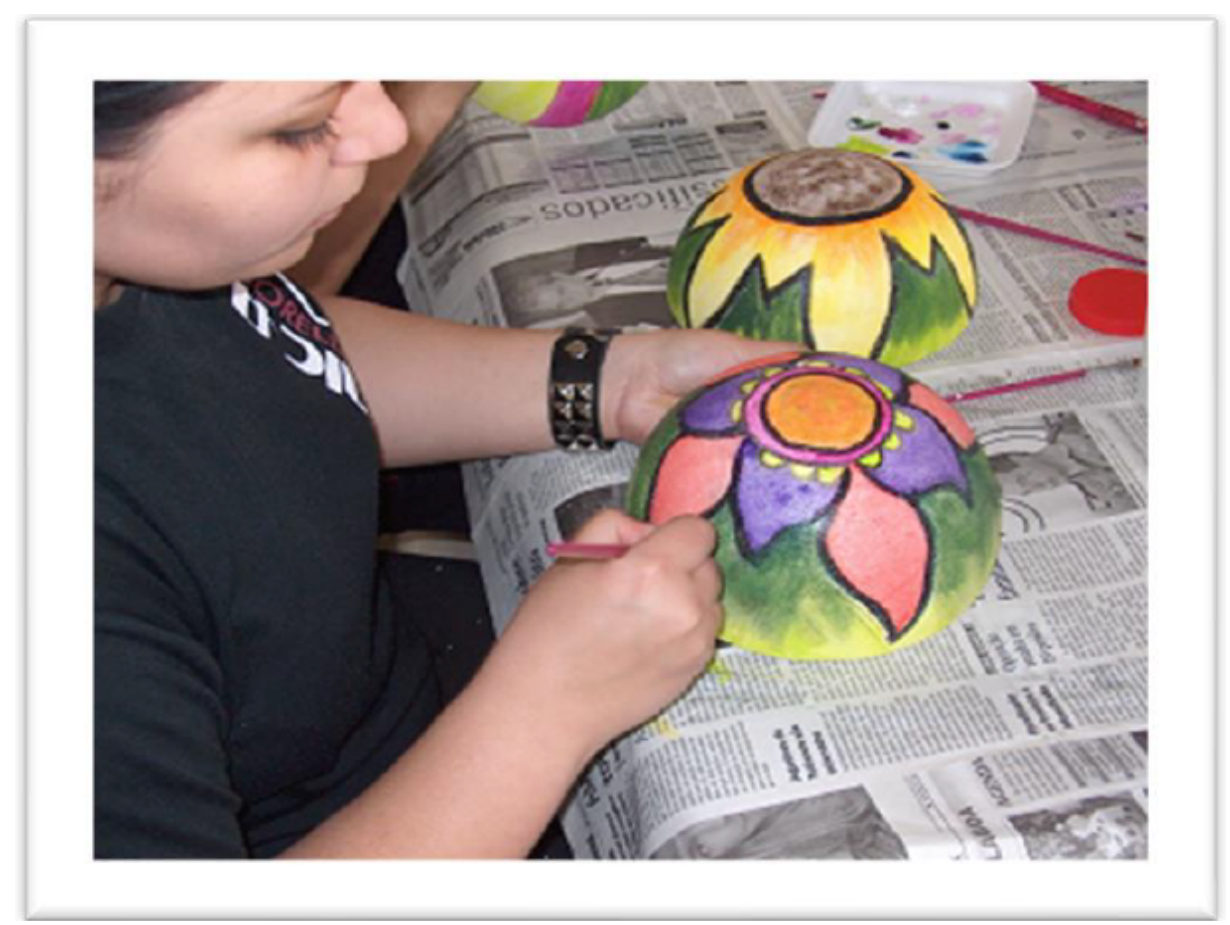

Fonte: As autoras

Figuras 10- Momento da produção de pinturas pelos alunos

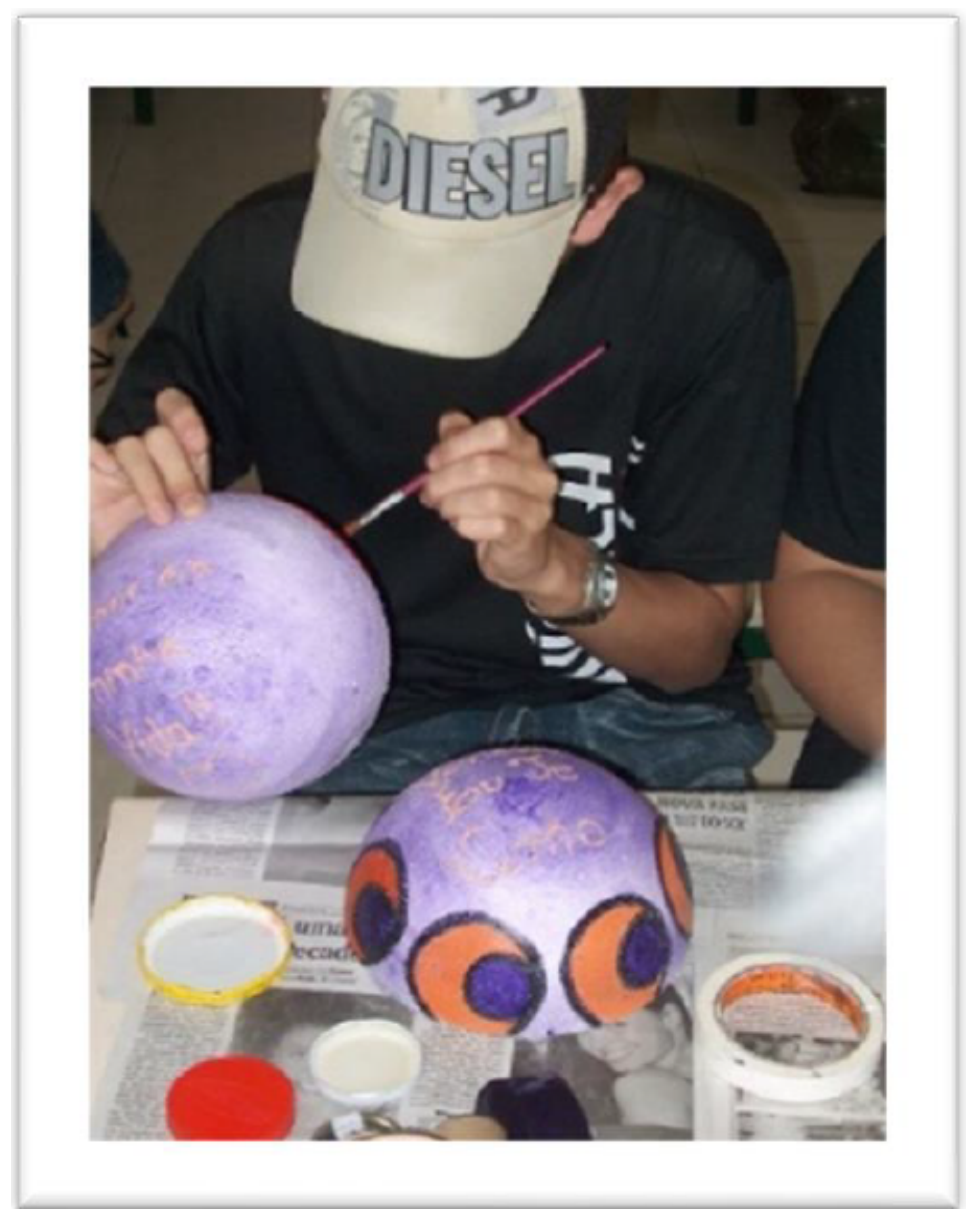

Fonte: As autoras 
Figuras 11- Momento da produção de pinturas pelos alunos

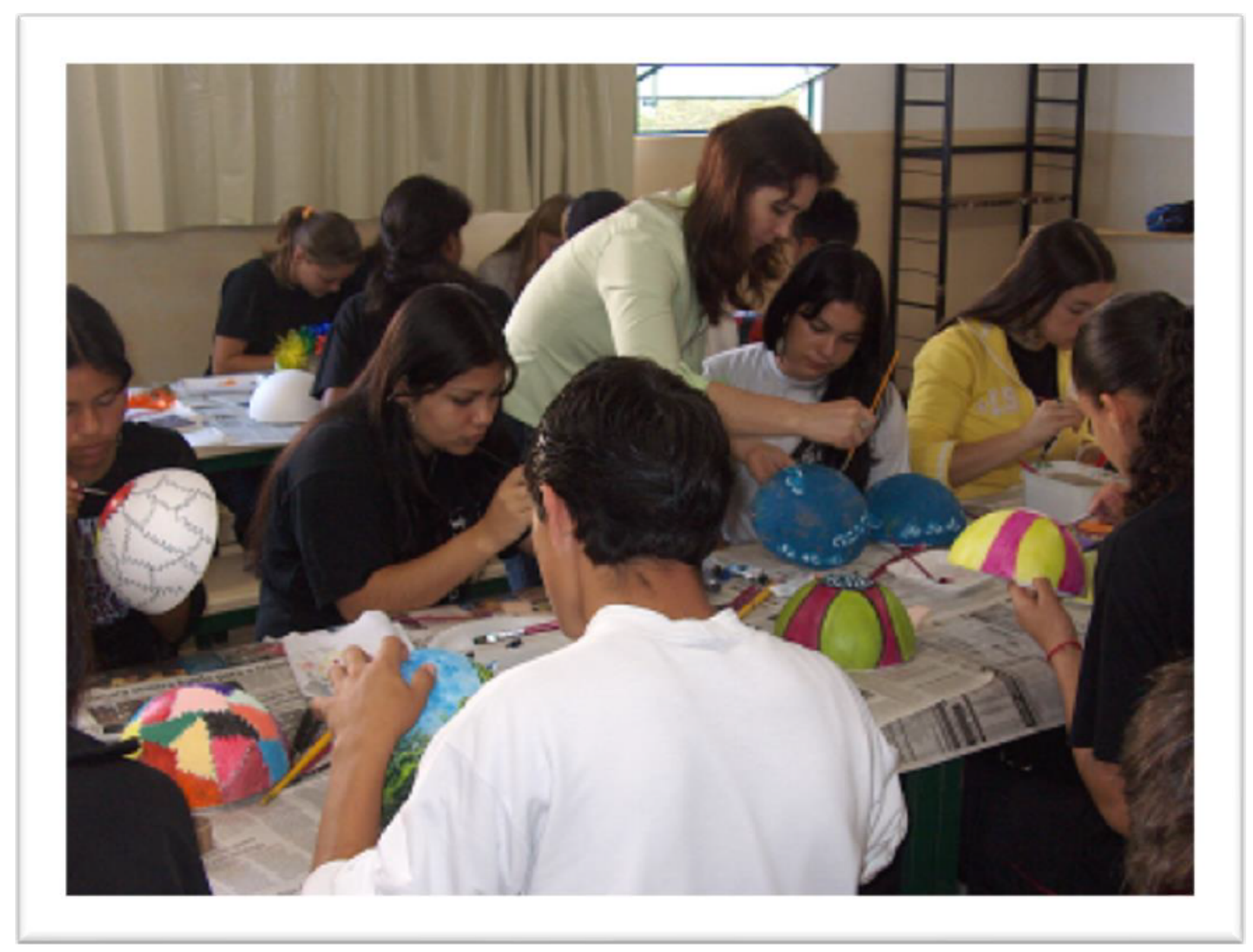

Fonte: As autoras

A pesquisa aponta que o aluno ao ter o conhecimento da cor nas artes visuais, tem possibilidade de qualificar sua produção, primeiro porque conheceu a teoria da cor e segundo porque soube na prática utilizar os conhecimentos da teoria numa produção artística pictórica, qualificando melhor sua criatividade e seu processo de produção, na qual a imagem de registro pelo portfólio da pesquisadora, mostra e dá visibilidade do processo poético nas Artes Visuais dos alunos e alunas da turma do Curso Técnico Integrado em Química Industrial do Colégio Estadual João Ricardo Von Borell du Vernay, na cidade de Ponta Grossa no Estado do Paraná.

Com os trabalhos realizados pelos alunos foi projetada uma instalação para que fossem apreciadas por todos do colégio (ver figuras 12,13, 14).

A Instalação é uma forma artística interdisciplinar de localização específica que prioriza a experiência da arte mais que a apreciação estética de objetos individuais. Parte de uma referência conceitual e efêmera. 
Figuras 12 - Instalação com as esferas pintadas pelos alunos

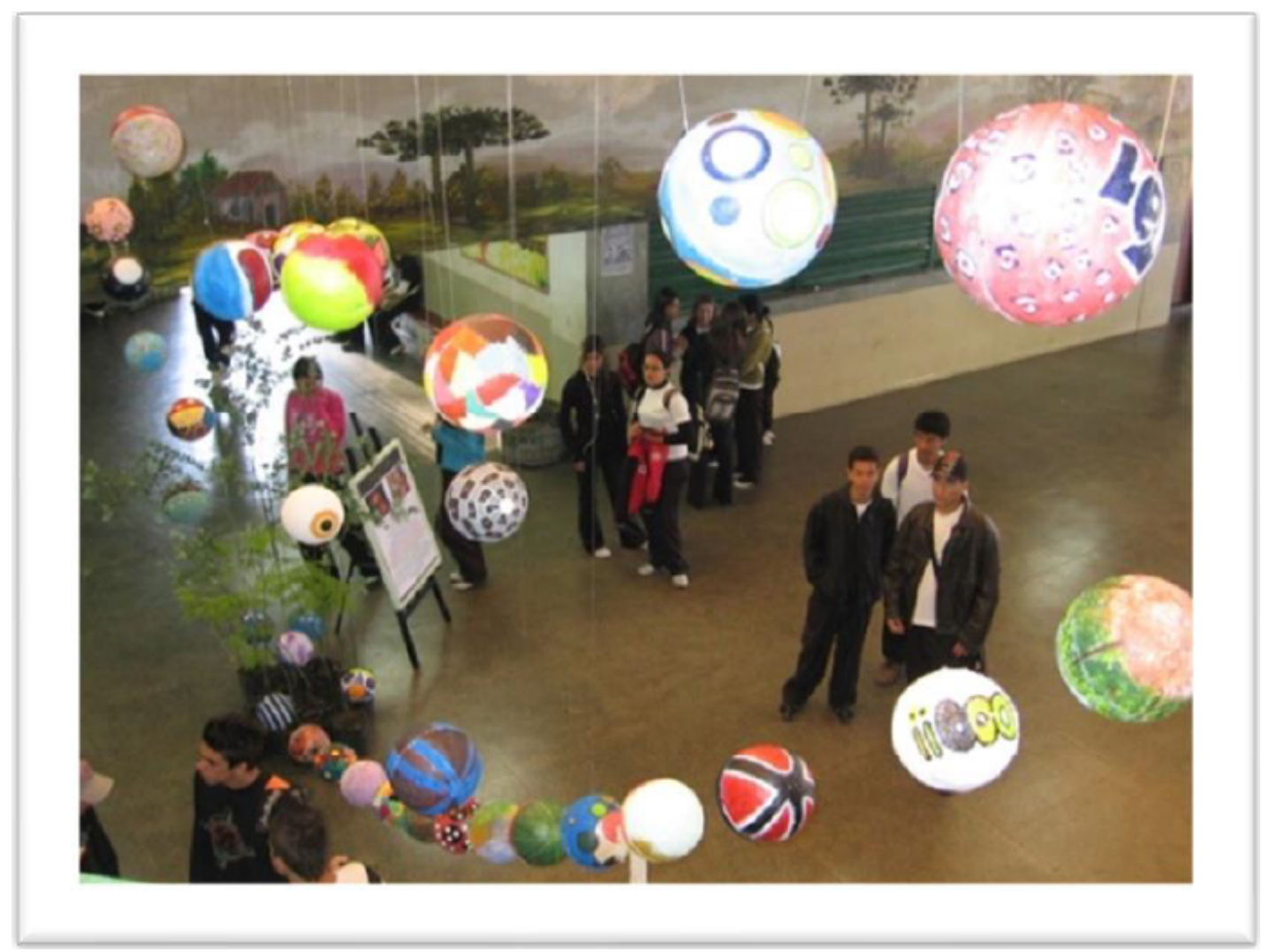

Fonte: As autoras

Figuras 13 - Instalação com as esferas pintadas pelos alunos

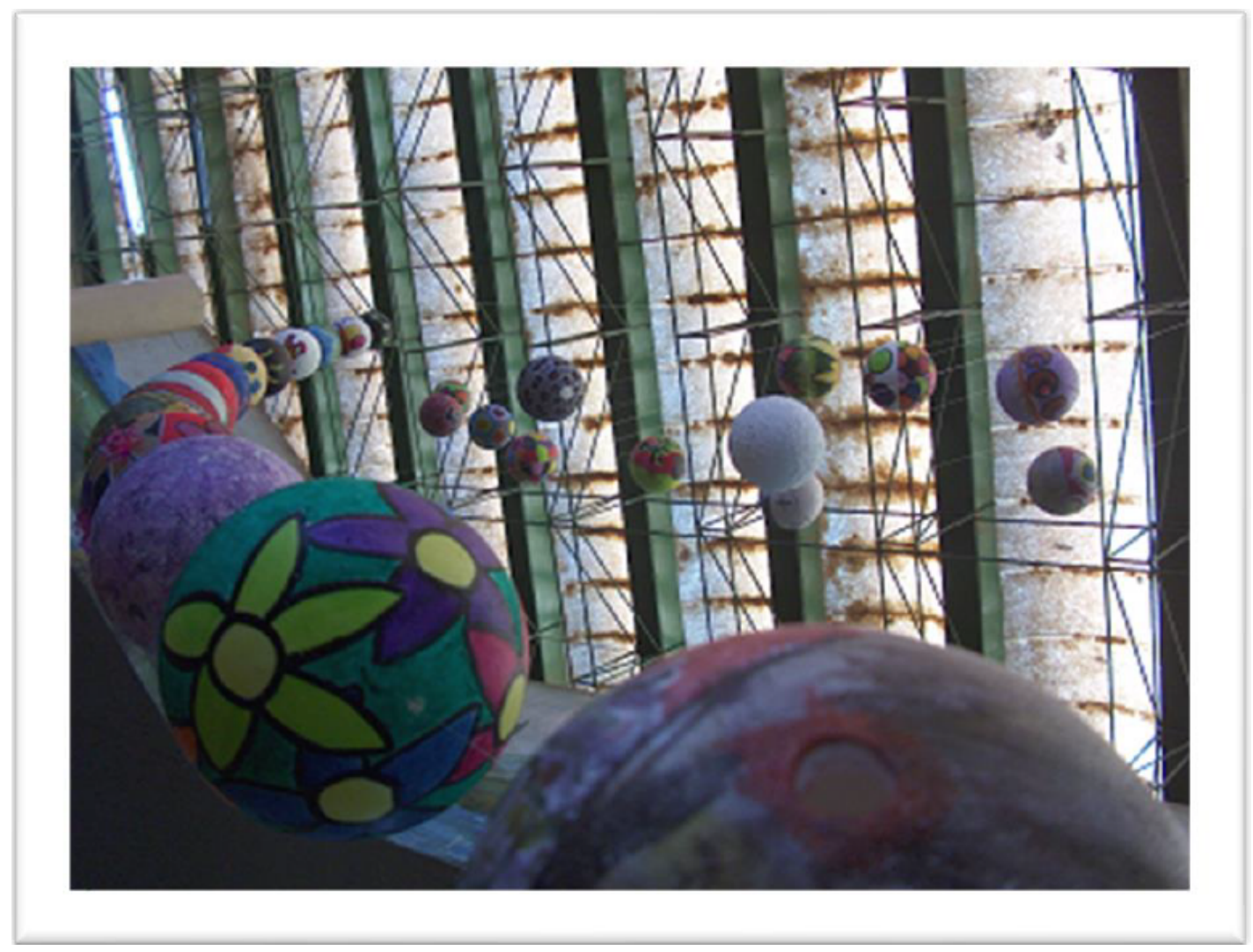

Fonte: As autoras 
Figuras 14 - Instalação com as esferas pintadas pelos alunos

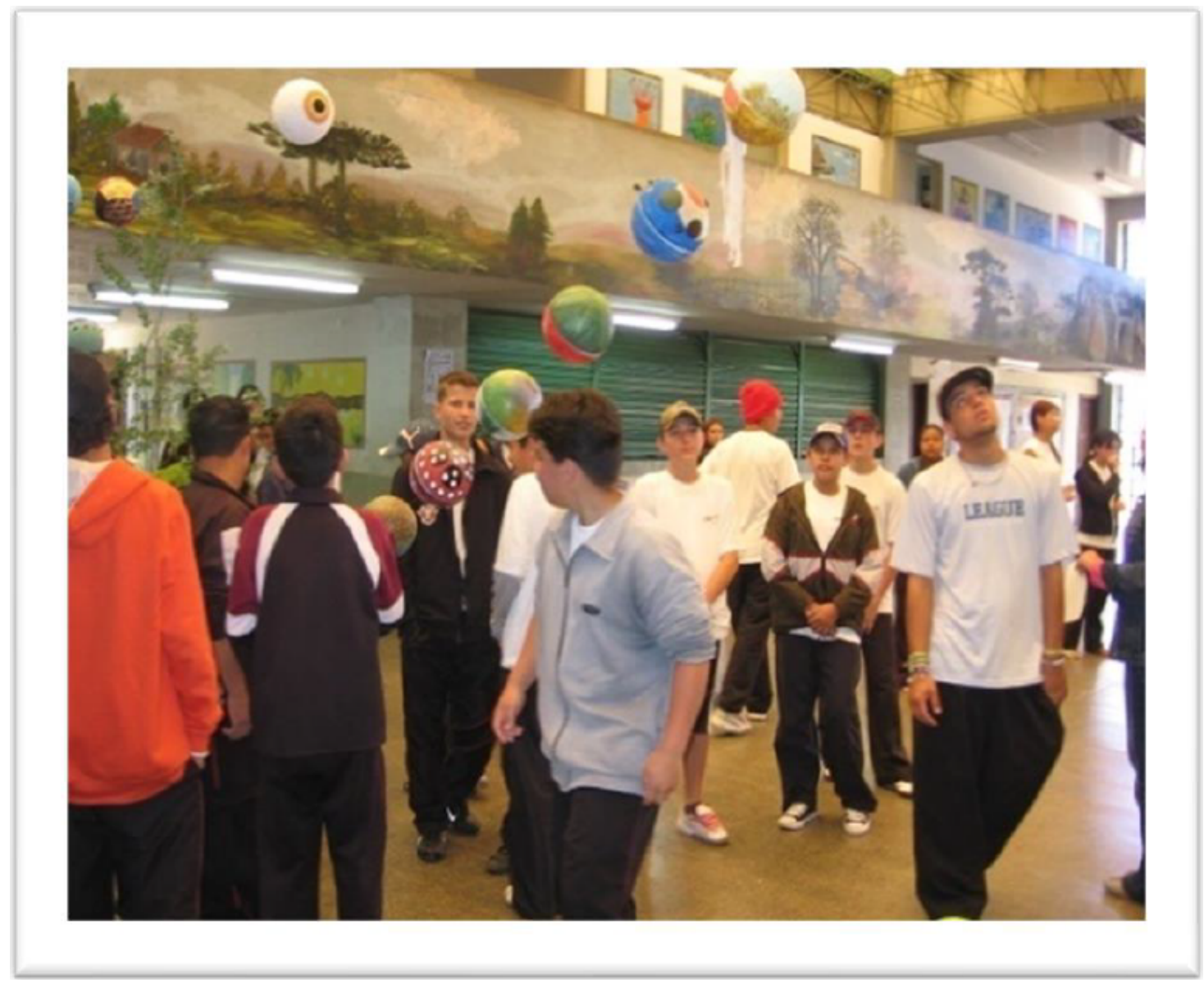

Fonte: As autoras

A disposição de elementos no espaço tem a intenção de criar uma relação com o espectador. O espaço físico escolhido para esta exposição foi o saguão interno do colégio. A vantagem deste local, deu-se em favor do grande espaço e circulação de alunos, professores e funcionários, tendo ainda vários pontos de visualização, podendo ter uma imagem total ou parcial da Instalação de acordo com o local observado, modificando os contrastes de cor da produção artística.

\section{CONCLUSÃo}

Esta pesquisa teve como objetivo investigar os conhecimentos do fenômeno cor no ensino das Artes Visuais com alunos do ensino médio técnico integrado em química industrial, bem como aprofundar esse conhecimento.

A partir de comentários feitos pelos alunos, e a análise das respostas dos mesmos referente ao questionário interrogativo sobre a cor, observou-se a falta 
de conhecimentos básicos referente a este fenômeno. A identificação e a interpretação dos alunos(as) frente às concepções da cor, era muito incipiente para uma turma de ensino médio. Somente dez por cento dos alunos relacionaram a origem da cor à luz, e foi surpresa para muitos ao compreenderem de como se dá o processo da percepção da cor em relação às sínteses aditiva e subtrativa, visto que o órgão da visão, composto de cones e bastonetes, juntamente com o processo de absorção, reflexão e refração da luz pelas moléculas que compõem os elementos na natureza e nos pigmentos que nos faz distinguir uma cor da outra.

Referente à inserção da cor na sociedade, a percepção tida pelos alunos(as) se destacada na questão de sua simbologia. Porém, quando se refere à sua utilização, este saber não é considerado como conhecimento fundamentado em estudos, mas sim adquiridos através da cultura, pois a cor também é um fenômeno cultural e simbólico.

$\mathrm{Na}$ investigação do uso da luz e sombra, na pintura artística, necessárias para a percepção do volume num plano bidimensional, a dificuldade dos alunos estava mais concentrada na representação da perspectiva do que a visualização da luz/sombra.

Em relação a leitura de imagem foi bastante superficial, visto que a leitura de imagem não era considerada um conhecimento de aprendizagem pelos alunos, já que essas ações educativas não eram desenvolvidas.

Referente à experienciação do material multimídia criado pela pesquisadora composto da Teoria de Paul Kle, mesmo não se tratando de substituir uma aula de Arte em relação ao conhecimento cor, mas de um material didático, ele foi bastante válido no seu objetivo, seja o de complementação, aprofundamento ou introdução de uma teoria da cor.

No quesito produções artísticas a professora regente da turma ressalvou que não é de seu conhecimento as práticas artísticas, somente a História da Arte. Este foi um dos problemas enfrentados na realização das poéticas, pois as dificuldades práticas artísticas dos alunos eram visíveis.

A exposição em forma de Instalação veio a despertar nos alunos o interesse 
nas produções artísticas, e que as Artes Visuais na escola têm um grande papel na vida do sujeito/aluno, no sentido de ser um modo dele expressar seus conhecimentos interconectados com suas emoções através da forma pictórica no caso específico, esta como uma sub-linguagem dentre tantas nas Artes Visuais dando o prazer, significado e compreensão de mundo a quem cria, a quem aprecia e interage com a Arte, em especial no espaço escolar, que é onde muitos dos alunos têm como o único espaço de aprendizado das Artes Visuais como linguagem, conhecimento e cultura.

\section{REFERÊNCIAS}

ANDRÉS, Maria Helena. Os Caminhos da arte: prefácio de Pierre Weil. Petrópolis: Vozes, 1977.

ARNHEIM, Ruldof. Arte e percepção visual: uma psicologia da visão criadora. 13. ed. São Paulo: Pioneira, 2000.

BARROS, Lilian Ried Miller. A cor no processo criativo: um estudo sobre a Bauhaus e a teoria de Goethe. São Paulo: Senac, 2006.

BRASIL. MEC - SECRETARIA DE EDUCAÇÃO PROFISSIONAL E TECNOLÓGICA. Programa de Integração da Educação Profissional Técnica de Nível Médio na Modalidade de Educação - PROEJA/Documento Base, Brasília, 2006 de Jovens e Adultos.

EISENBACH, Maysa Nara. et al. Uma luz na história da arte. In. Arte/vários autores - Curitiba: SEED, 2006.

FARINA, Modesto. Psicodinâmica das cores em comunicação. São Paulo: Edgard Blücher, 1982.

FREIRE, Paulo. Pedagogia da autonomia: saberes necessários à prática educativa. São Paulo: Paz e Terra, 1996.

GIL, Antônio Carlos. Como elaborar projetos de pesquisa. 3. ed. São Paulo: Atlas, 1991.

GOETHE, Johann Wolfgang Von. Doutrina das cores. São Paulo: Nova Alexandria, 1993. 
GOMBRICH. Ernst Hans Josef. A História da Pintura. 16 ed. Rio de Janeiro: LTC, 1999.

GUIMARÃES, Luciano. A cor como informação: a construção biofísica, linguística e cultural da simbologia das cores. São Paulo: Annablume, 2000.

HERNÁNDEZ, Fernando. Cultura Visual, mudança educativa e projeto de trabalho. Porto Alegre: Artes Médicas Sul, 2000.

IAVELBERG, Rosa. Para gostar de aprender arte: sala de aula e formação de professores. Porto Alegre: Artmed, 2003.

LIBÂNEO, José Carlos. Adeus professor, adeus professora: novas exigências educacionais e profissão docente. 7. ed. São Paulo: Cortez. 2003.

LUDKE, Menga.; ANDRÉ, Maria Eliza Dalmazo Afonso.Pesquisa em educação: abordagens qualitativas. São Paulo: EPU, 1986.

MAYER, Ralph. Manual do artista de técnicas e materiais. 2. ed. São Paulo: Martins Fontes, 1999.

MAZZOTI, Alda. et al. O método nas ciências naturais e sociais. São Paulo: Pioneira 1998.

MINAYO, Maria Cecilia de Souza. O desafio do conhecimento. São Paulo: HUCITEC, 1994.

NOVAES, Adalton. O olhar. São Paulo: Companhia das Letras, 1988.

NUNES, Ana Luiza Ruschel. Trabalho, arte e educação: formação humana e prática pedagógica. Santa Maria: Editora UFSM, 2004.

OSTROWER, Fayga Perla. Universo da arte. 2. ed. Rio de Janeiro: Campus, 1983.

PEDROSA, Israel. Da cor à cor inexistente. Rio de Janeiro: Léo Christiano Editorial Ltda. Co-editado, 1982.

O Universo da cor. Rio de Janeiro: Senac Nacional, 2006.

PENNA, Maura. O dito e o feito: política educacional e arte no ensino médio. João Pessoa: Manufatura, 2003. 
PIGMENTOS: as cores da terra de Lascax à Picasso. Canadá: M6. 2000. Vídeo-filme exibido pela TV ESCOLA. Série: Linhas, formas e cores.

REVISTA CARAS. George Seurat: um artista que usaria a ciência a favor da arte. V. 14, 2007, Coleção: As pinturas mais valiosas do mundo.

ROSSI, Maria Helena Wagner. Imagens que falam: leitura da arte na escola. Porto Alegre: Mediação, 2003.

SETEC - SECRETARIA DE EDUCAÇÃO PROFISSIONAL E TECNOLOGIA Disponível em: <http://portal.mec.gov.br/educacao-profissional-e-tecnologica-ept Acesso em: 18/03/2019>

SOUZA, Alcidio Mafra. Artes plásticas na escola. 5. ed. Rio de Janeiro: Bloch Editores. 1974. Rev. e aum.

STTICKLAND, Carol. Arte comentada: da pré-história ao pós-moderno. Rio de Janeiro: Ediouro, 2004. 


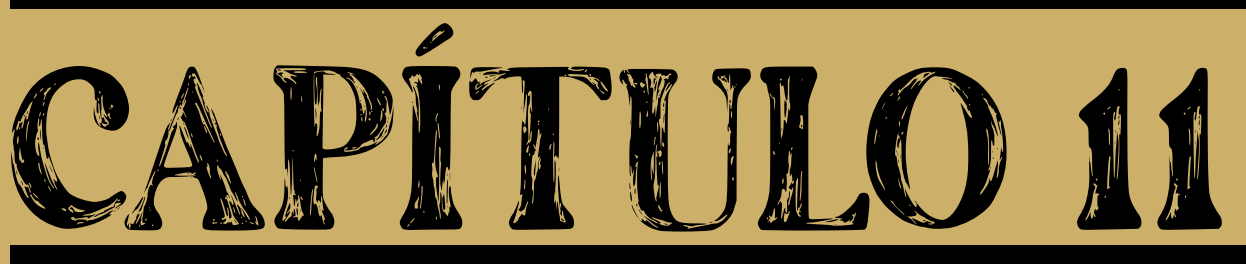

\title{
ENCONTROS COM O FILME A 'ÁRVORE DA VIDA':
} DISPARADORES PARA PENSAR A EXPERIÊNCIA EDUCATIVA ${ }^{1}$

\author{
Vivien Kelling Cardonetti ${ }^{2}$ \\ Marilda Oliveira de Oliveira ${ }^{3}$
}

1 Uma versão ampliada deste artigo foi publicada em 2017 na Revista Digital do LAV - Santa Maria - vol. 10, n. 2.

2 Pós-Doutora e Doutora junto ao Programa de Pós-Graduação em Educação (PPGE), na Universidade Federal de Santa Maria (UFSM). Membro do GEPAEC - Grupo de Estudos e Pesquisas em Arte, Educação e Cultura da UFSM. E-mail: vicardonetti@gmail.com

3 Doutora em História da Arte, credenciada no Programa de Pós-Graduação em Educação, Mestrado e Doutorado (PPGE/CE/UFSM), na Linha de Pesquisa LP4: Educação e Artes. Coordenadora do GEPAEC - Grupo de Estudos e Pesquisas em Arte, Educação e Cultura da UFSM.

E-mail: marildaoliveira27@gmail.com 
A penumbra do cinema não deixa transparecer os sentimentos que me assaltam no momento... Irritação, desconforto e constrangimento são emoções que passam a me acompanhar. Não tenho certeza se o incômodo estava relacionado somente por visualizar as pessoas se levantarem das cadeiras e irem embora, ou se era por eu não ter coragem suficiente de fazer o mesmo. Além do transtorno que o movimento da plateia causava, não escondiam sua decepção, pois desejavam deixar claro através de comentários o porquê estavam se retirando.

Imagens ilógicas, discordantes e desconexas estavam todas na tela. Imagens que deixaram de fazer parte do seu lugar no tempo crônico, mas que agora estavam ali, errantes, suspensas no ar. A linearidade e a totalidade foram abaladas. Sim, são imagens vivas em um universo acentrado!

Ao compor com diferentes cenas descritas por mim de 'desarmônicas', observo que suas bordas não se ajustam, mas ressoam como se um tênue fio transpassasse entre elas. Visualizo também alguns fios soltos e, talvez por isso, outros fios se sentem encorajados e passam a fazer parte deste emaranhado de fios. Por vezes, surgem elos frouxos, lacunas e hiatos entre as imagens, possibilitando a dispersão e a presença do acaso. Desponta outro tipo de reencadeamento entre as imagens, a presença do 'interstício' se faz presente.

Constato que o protagonista do filme também é um espectador, pois desconhece o que vai acontecer, não é mais o agente da situação. Essa sensação me faz sentir mais próxima do ator em cena, colocando-me numa relação de empatia com o personagem do filme. Sentir-me outro sem ser o outro.

No filme, a congruência da organização e da sequência entre a ação e a reação passa a ruir, a ponto de não existirem mais os momentos fortes e fracos delimitados, qualquer cena pode ser alastrada em horizontes mais dilatados e múltiplos, de acordo com as contingências do momento. Isso passa a me desconcertar, pois os acontecimentos estão ao sabor do que não pode ser auspiciado. Dessa forma, o movimento deixa de acatar seu eixo central, e o tempo, por sua vez, também sai dos eixos. Ao assistir ao filme 'A Árvore da Vida', inaugura-se para mim, pela primeira vez, uma relação diferente com a imagem fílmica... (Fragmentos do diário pessoal da primeira autora, agosto de 2012).

O filme acabou e a pergunta que fica é: Que filme é esse? Sobre o que trata, afinal? Sobre religião? Sobre Deus? Sobre os hábitos cotidianos de uma família? Sobre as divergências de posicionamento frente ao modo como vemos/vivemos a vida? Sobre como educar os filhos? Sim, sobre tudo isso, mas principalmente trata sobre o 'silêncio'. As perguntas que o silêncio nos faz. Por que eu? Por que isso aconteceu comigo? De onde vem essa dor? Por que calamos quando queremos dizer alguma coisa? Por que nos arrependemos por não ter dito? Apegamo-nos a questões tão pequenas que, quando realmente nos deparamos com algo maior que 
nossas ninharias, paralisamos. Foi assim que me senti quando o filme acabou e pensei: E agora, como será a discussão sobre esse filme? Que relações podemos estabelecer com a docência? Que interlocuções são possíveis? Como os estudantes perceberam o filme?

A discussão com os acadêmicos girou em torno das 'nossas crenças'. Em que acreditamos? Como construímos nossas verdades? O que fazemos em nome delas? Para mim, essa não era a questão principal do filme, mas acompanhei a discussão e o que mais me chamou a atenção foram algumas conclusões lançadas naquele encontro: As nossas verdades nos impedem de amar. As nossas crenças nos sufocam ao ponto de nos cegar. Quando acreditamos muito em alguma coisa não conseguimos perceber o que acontece à nossa volta. $\mathrm{O}$ que nos impede de mudar o curso da nossa vida são as amarras que nós mesmos nos colocamos.

Assim, para mim, o que ficou desse encontro foi o impacto, não com o filme, mas com a discussão com os estudantes que me mostraram uma outra forma de ver o mesmo, pois em nada aproximou-se com aquilo que pensei, anotei e elaborei.

Hoje, quando penso nesse encontro e tento elaborar o que ficou da experiência com 'A árvore da vida' sinto uma sensação de conforto e aprendizagem. Já não lembro das imagens fílmicas, mas dos rostos dos estudantes elaborando suas histórias sobre o que viram. Acho que é um pouco disso que tentei fazer aqui. (Fragmentos do diário pessoal da segunda autora, junho de 2015).

Neste capítulo, exploramos alguns fragmentos dos nossos diários pessoais sobre experiências fílmicas e demonstramos como essas narrativas se tornaram disparadoras do pensar, tendo a potência de nos arremessar a uma paisagem problematizadora. Esses fragmentos se referem a duas experiências que ocorreram em locais e momentos distintos, mas que de certa forma passaram a ressoar e a coexistir nesta escrita. Um dos encontros aconteceu no cinema, em uma circunstância distante das atividades acadêmicas, e o outro ocorreu em um trabalho desenvolvido com os estudantes da Graduação em Artes Visuais da Universidade Federal de Santa Maria - RS, nas disciplinas de Estágio Supervisionado III e IV (OLIVEIRA, 2014).

A relação estabelecida com o filme A Árvore da Vida (2011) e com o cenário circunstancial desses dois encontros possibilitou a produção de diferentes disposições e tessituras. Passamos a dar atenção ao quanto esses dois momentos nos forçaram e violentaram a pensar a imagem fílmica, a experiência educativa e a vida. 
Por apresentar outro tipo de imagem, foi possível estabelecer inusitadas relações com o filme, facultando o tensionamento favorável para pensar aquilo que não é auspiciado e brindando-nos com a oportunidade de ensaiar uma paisagem ampla de possibilidades e sentidos. O tensionamento com aquilo que é adverso e incompatível permitiu que o pensamento fosse coagido a pensar em outras coisas, interrompendo a apatia e a paralisia que por vezes nos aprisiona.

Em busca de atender aos anseios da investigação, optamos por uma pesquisa de cunho narrativo, presentificada nos fragmentos dos nossos diários textuais. Zabalza (2004) considera o diário como um local de intercâmbio, onde as pessoas, ao narrar, vão "travando uma 'conversa' consigo mesmo[as] e com os virtuais destinatários do relato" (ZABALZA, 2004, p. 49, grifo do autor). Nessa pesquisa, o diário passou a ser um espaço narrativo dos nossos pensamentos, pois nele expressamos as impressões que tivemos do encontro fílmico e das experiências educativas vivenciadas a partir do filme, problematizando-as. O diário possibilitou uma visão panorâmica dos sentidos produzidos nessas experiências, apresentando as próprias redes de afetos que potencializaram ou não o pensar.

A partir das paisagens singulares do encontro vivenciado, procuramos explorar o atravessamento da imagem fílmica selecionada, das narrativas produzidas nos diários e dos conceitos operados na pesquisa, especialmente os conceitos de imagem-movimento e imagem-tempo (DELEUZE, 1983; 1990; 2010). Esses desdobramentos tiveram importância, porque passaram a se conectar e se complementar, contribuindo para esta escrita.

\section{O QUE NOS IMPELE A PENSAR}

O pensamento não pode ser confundido com o evento da recognição. Esta não necessita de esforço, pois gira em torno de associação e de reconhecimento, reencontrando-se sempre com o habitual e com o familiar. Além de se unir ao sujeito ou ao objeto correspondente, conecta-se também com valores vigentes e universais instituídos, por isso passa a ser uma operação redundante. O pensamento, por sua vez, é involuntário, necessita ser coagido e violentado; conta com as circunstâncias do instante e com aquilo que o impulsiona a pensar; está aberto 
ao incomum, ao intolerável e ao extraordinário.

Os encontros fortuitos lidam com a imprevisibilidade, com o não conhecido, com aquilo que não pode ser antecipado, causando o estranhamento. E é justamente esse encontro surpreendente, movediço e oscilante que assegura a premência daquilo que é pensado. Quando estamos à mercê do inesperado em um encontro, distanciamo-nos da realidade costumeira e da referência cognitiva que nos causam segurança e é esta atmosfera acontecimental que assegura a necessidade do que pensamos.

Deleuze (2006b) assinala que é notório que os "atos de recognição existem e ocupam grande parte de nossa vida cotidiana: é uma mesa, é uma maçã (...). Mas quem pode acreditar que o destino do pensamento se joga aí e que pensemos quando reconhecemos?" (DELEUZE, 2006b, p. 197). Pensar não significa exercitar movimentos mecânicos de reconhecimento e de combinação com o corriqueiro ou com algo preestabelecido, pensar está relacionado com a criação.

Ao criar, movimentamos a produção de diferenças, e não de similaridades, uma vez que passamos a pensar o que ainda não existe, em vez de nos contentarmos com o que já é dado e consolidado. É por isso que ao pensar se abrem possibilidades de inventar diferentes perspectivas de vida para o mundo em que vivemos, pois "o melhor dos mundos é não aquele que reproduz o eterno, mas aquele em que se produz o novo, aquele que tem uma capacidade de novidade, de criatividade" (DELEUZE, 2007, p. 136). Nesse sentido, pensar pressupõe se desprender de dogmas, abrindo mão da necessidade de um roteiro que sirva de apoio e que garanta as certezas fáceis. Os pensamentos mais impetuosos são os que duvidam das verdades impostas e levam em consideração o falso e a fabulação.

$\mathrm{Na}$ experiência educativa, por vezes, com a intenção de auxiliar a leitura de um texto, por meio da visualização de uma imagem ou de um filme, passamos a direcionar os estudantes a fazerem associações e interpretações endossadas por verdades que acreditamos serem universais. No entanto, ninguém "poderia, com regra alguma, facilitar a leitura, consistindo esta num ato criador que não admite suplentes nem colaboradores" (DELEUZE, 2006a, p. 90). Não que as interpreta- 
ções concebidas ou reproduzidas pelos professores não possam ser coerentes e válidas, mas são apenas mais uma das verdades possíveis.

Dessa forma, para produzir movimentos que vão além de ou que não se acomodem em uma recognição, faz-se necessário problematizar o que nos é dado como verdade e se abrir a inusitados fluxos de forças que nos impulsionem a inventar outras construções de sentido. Ao pensar, não estamos (re)conhecendo a verdade, mas sim produzindo-a, pois esta é sempre uma verdade do seu tempo.

O cinema para Deleuze (2010), principalmente o cinema moderno foi um dos intercessores que o instigou a pensar e a produzir sua filosofia. Deleuze revela que "a criação são os intercessores. Sem eles não há obra. Podem ser pessoas (...) mas também coisas, plantas, até animais, (...). Fictícios ou reais, animados ou inanimados" (DELEUZE, 2010, p. 160). Vasconcellos (2006), a partir de estudos na obra de Deleuze, expressa que "o intercessor é qualquer encontro que faz o pensamento sair de sua imobilidade natural, de seu estupor. Sem os intercessores não há criação. Sem eles não há pensamento" (VASCONCELLOS, 2006, p. 7).

Apostamos na ideia de que as imagens fílmicas possam ser disparadoras do pensar, arremessando-nos a uma paisagem problematizadora. Não a imagem em si, mas a relação que se estabelece com a imagem e com as implicações do cenário circunstancial de cada encontro. A imagem é relação, por isso não há como pensar a imagem individualmente, pois ela é aliança. É no emaranhado dos liames produzidos com a imagem fílmica que talvez venhamos a ser incitados e contagiados por signos que se encontram nesse potente campo de confluências em que estamos enredados.

O desafio talvez esteja em se deixar afetar não por vozes conhecidas, "mas sim a voz de um outro, uma voz real, profunda, que incomoda" (BLANCHOT, 1997, p. 297), que provoca o pensar, que faz duvidar das certezas, que abala as verdades, que propicia a problematização de valores há muito tempo estagnados, ocasionando o movimento de transgressão e de renovação. 


\section{DISPARADORES DO PENSAR: ENCONTROS COM O FILME A ÁRVORE DA VIDA}

Ao sermos atravessadas e capturadas pelos dois encontros com o filme $A$ árvore da vida (2011), narrados nos diários pessoais, sentimos a necessidade de nos aproximar cada vez mais de outros intercessores que estudaram e estudam o cinema. As duas obras de Gilles Deleuze sobre a arte cinematográfica foram determinantes para que viéssemos a pensar as imagens fílmicas de uma forma ampliada. Deleuze dedicou ao cinema dois volumes: Cinema 1 - Imagem-movimento (1987) e Cinema 2 - Imagem-tempo (1990). Ambos foram importantes para ajudá-lo a pensar e problematizar essa arte e a criar conceitos filosóficos. Nesses exemplares, dois conceitos principais são trabalhados: o movimento e o tempo.

Para dar conta das exigências que os fragmentos narrados nos diários dispararam, passamos a nos debruçar mais demoradamente em alguns conceitos dessas duas obras: imagem-movimento e imagem-tempo. Esta colocação reafirma a implicação da teoria e da prática, pois, devido à premência do momento, sente-se ora a necessidade de buscar conceitos para compreender o que está acontecendo na investigação, ora a teoria estudada faz com que o nosso olhar fique mais atento e se direcione para determinadas coisas que, talvez, ficariam imperceptíveis se não houvesse o chamamento da teoria. Teoria e prática vão se atualizando intensamente no decorrer da pesquisa.

A escolha em explorar o filme A Árvore da Vida (2011), com direção de Terrence Malick, partiu da intenção de investir em imagens que produzissem diferenças e não similaridades, abrindo mão das relações de reconhecimento e de associação. Afinal, as imagens fílmicas que nos incitam a sair da posição cômoda de reconhecimento em que muitas vezes nos encontramos, que nos incomodam pelas lacunas e vazios produzidos em cena, que nos tocam a ponto de causar incômodos e inquietações, são as que mais nos afetam e nos levam a ter sensações e experiências estrangeiras e insólitas.

O filme A Árvore da Vida (2011), ganhador da Palma de Ouro do Festival de Cannes, traz no elenco Brad Pitt, Sean Penn, Jessica Chastain e Hunter McCracken. Para alguns críticos, o gênero do filme é classificado como drama, para 
outros, como um documentário fotográfico. Entretanto, mais importante do que saber a qual categorização o filme pertence, é se deixar embriagar pela poesia das palavras e pela intensidade das imagens apresentadas.

\section{IMAGEM-MOVIMENTO E IMAGEM-TEMPO}

Deleuze (1990) discorre sobre o fato de que, no cinema clássico, o cinema se reduz à imagem-movimento. Por acolher um esquema sensório-motor, o tempo se submete ao movimento, ou seja, ocorre a sujeição do tempo ao movimento, é o automovimento da imagem.

No cinema moderno, a imagem cinematográfica se converte em uma imagem-tempo quando o movimento passa a se sujeitar ao tempo, é a autotemporalização da imagem. O tempo é visto na sua forma pura e as situações são caracterizadas pelos vazios e pelas descontinuidades, tornando-se dispersivas. São realizadas por cortes incongruentes e não mais por relações de atração e associação das imagens, como acontecia na imagem-movimento.

Deleuze (2010) esclarece que "as imagens-tempo não significam de modo algum o antes e o depois, a sucessão (...). A imagem-tempo não se confunde com o que se passa no tempo, são novas formas de coexistência, de colocação em série, de transformação" (DELEUZE, 2010, p. 158). Passado, presente e futuro ocupam o mesmo espaço no tempo, abolindo a progressão e a linearidade entre os três tempos. A imagem-tempo, por não mais responder aos estímulos sensório-motores, permite-se arrastar pela 'visão' dos acontecimentos.

No regime temporal da imagem-tempo, deixa de existir o tempo cronológico que pode ocasionalmente ser importunado por movimentos incomuns e passa a haver um tempo crônico, não linear e progressivo, que gera movimentos inevitavelmente inusitados e imprevisíveis. As imagens fílmicas, neste regime, são arremessadas a outras imagens, potencializando a dispersão. Não se tem como prever quais imagens estarão em jogo, que reações serão realizadas, o que os signos farão evocar e o que se produzirá de tudo isso. É justamente esse cenário incerto e inesperado que possibilita encontros fílmicos sempre singulares e em vias de acontecer. 
O cinema apresenta, na imagem-tempo, uma diferente relação com o pensamento, pois ocorre "a supressão de um todo ou de uma totalização das imagens, em favor de um fora que se insere entre elas" (DELEZE, 1990, p. 226). Possibilita-se, dessa forma, pensar em diferentes alianças, pois o tempo não é mais regido pelo verbo 'ser', e sim pela conjunção 'e', não mais como 'ser' e sim como 'entre', porque atua nos vacúolos das imagens, e não mais na associação de imagens. A imagem recebe alforria de seu limitado decreto representativo, recognitivo, ilustrativo e demonstrativo.

A partir do que foi exposto, podemos perceber que o filme A Árvore da Vida (2011) traz em cena a imagem ótica e sonora pura, elemento primordial da imagem-tempo. Essa imagem que nos incomoda, que nos escapa a todo momento e que nos tira dos eixos é a que também nos provoca a ter outras experiências com as imagens. Semelhante incômodo, desconforto e perplexidade fora perceptíveis na escrita dos diários que anuncia este texto, pois em algumas situações o estranhamento foi tanto que levou à rejeição, a ponto de certas pessoas se retirarem do cinema antes do filme terminar. Em outras, na experiência com os acadêmicos, foi possível perceber o quanto as discussões em relação a um mesmo filme se mostraram múltiplas, distanciando-se da possibilidade de qualquer consenso.

Fazer funcionar áreas que se acham paralisadas e definidas em nós causa-nos, por vezes, dor e sofrimento. É desafiador se deixar afetar pela visão dos acontecimentos, pelos movimentos imprevisíveis, pelos hiatos, pelos cortes discordantes, pelos percursos desviantes e pelo campo multifacetado que uma imagem-tempo pode incitar.

\section{AS INESGOTÁVEIS NUANCES DA IMAGEM}

Deleuze (1990) evidencia que as imagens óticas puras "sempre elevam a coisa a uma singularidade essencial, e descrevem o inesgotável, remetendo sem fim a outras descrições" (DELEUZE, 1990, p. 61). As descrições fazem explorar os inexauríveis matizes e facetas da imagem que se fixam em algo, demorando-se a ponto de investigar outras perspectivas da mesma coisa.

A imagem sensório-motora apresenta um modo de encadeamento diferen- 
te da imagem ótica e sonora pura, pois na primeira ocorre o encadeamento de uma imagem-percepção a uma imagem-ação, acatando uma triagem conveniente. Passa-se a "associar à coisa muitas outras coisas que se parecem com ela no mesmo plano, na medida em que todas suscitam movimentos semelhantes" (DELEUZE, 1990, p. 61).

Na segunda, os encadeamentos entre as imagens se tornam enfraquecidos, pelo fato das linhas que unem os acontecimentos serem rompidas a todo o momento. A estrutura que assegurava a sequência e a sucessão das imagens passa a ruir. Não ocorre prolongamento em movimento, pois há uma relação constante com o imprevisível, com o que acontece no 'entre', com o que ocorre nas lacunas e nos hiatos das imagens.

A rarefação das imagens do filme A Árvore da Vida (2011) convida e encoraja que outras relações possam ser realizadas e diferentes descrições aconteçam, reportando-se a outras imagens. Vislumbra-se, no 'entre' das cenas, pequenos microrganismos e atividades celulares, imagens oceânicas, atômicas, vulcânicas, desérticas e astronômicas. As imagens passam a estar sujeitas a permanentes interrupções e escapes - esse desencadeamento leva à dissipação e à criação de múltiplas possibilidades, distanciando-se do previsível, do trivial, do lugar-comum, da monotonia, da matriz.

Em vez de serem interpretadas, essas imagens nos oferecem singulares experienciações, pois elas ressoam em múltiplas direções e sentidos, convidando-nos a engendrar diferentes vinculações. Ao tirar proveito de sua faculdade plural, essas imagens são impelidas a outras imagens, diversamente do sentido representativo em que voltam para si mesmas. Essa valência múltipla contribui para que o observador concorra para sua profusão e dispersão. Isto nos faz pensar que "uma imagem nunca está só. O que conta é a relação entre as imagens" (DELEUZE, 2010, p. 71-72).

É nesta relação que a problematização do pensamento se faz presente, pois nas descrições sobressaem outros matizes, propiciando diálogos com liames por vezes desconhecidos e instigantes. $\mathrm{E}$, retornando mais uma vez aos diários da pesquisa, fazendo-nos ver o que nos parecia impossível perceber, a ponto de nos 
questionarmos se havíamos assistido ao mesmo filme.

As descrições, por se encontrarem deslocadas, são questionadas e substituídas, propelindo a outras conexões. A provisoriedade passa a ser uma característica das imagens-tempo, pois elas estarão sempre em deslocamento, de acordo com as exigências e as forças em cena.

\section{O CINEMA DE VIDÊNCIA}

Nas imagens-tempo apresentadas no filme, os personagens não reagem ao que lhes acontece, por se encontrarem em estado de errância. Os personagens são indiferentes ou são tomados de surpresa pelos acontecimentos, pois não agem e nem reagem imediatamente. Eles desejam ver o que acontece antes de tomar qualquer iniciativa.

Esse cinema é considerado como de 'vidência', pois os personagens passam a ser observadores das situações e atuam por afetos que excedem a cena dramática do filme e não por forças táteis (DELEUZE, 1990). Os acontecimentos são narrados de forma casual, pois estão à mercê do imprevisto, do inusitado. Não existe mais um espaço específico; os espaços são lacunares e não estão mais associados, caracterizando-se, dessa forma, a perambulação e a dispersão. Os personagens do filme Sr. O'Brien e Sra. O'Brien, Jack criança e adulto, variam, levando em vista que ora se apresentam como protagonistas, ora como coadjuvantes.

Ao se trabalhar com imagens óticas e sonoras puras, o cinema de ação passa a ser substituído pelo cinema de vidência, acarretando na interrupção do esquema sensório-motor e na suspensão do prolongamento da ação. A imagem-movimento, aprisionada ao vínculo sensório-motor, oferece apenas uma imagem indireta do tempo, entretanto a imagem ótica e sonora pura oferece uma imagem-tempo que propicia ao olho obter uma função de vidência, uma posição visionária.

A vidência do olho propicia que a coisa apreendida se alastre em circuitos cada vez mais amplos, conectando-se com as imagens-lembrança que ela mesma fomenta. É possível perceber que o filme trafega nesses lençóis de passado, 
entre a vida atual de Jack e a vida de Jack criança. As imagens-lembrança, por estarem relacionadas com os lençóis de passado, entram em diálogo com "algo real e imaginário, físico e mental, objetivo e subjetivo, descrição e narração, atual e virtual" (DELEUZE, 1990, p. 61, grifo do autor).

\section{O MOVIMENTO SILENCIOSO DA IMAGEM}

O encontro com o filme A Árvore da Vida (2011) nos oferece inúmeras imagens silenciosas, com a intensidade para nos arrebatar da posição inerte e tranquila em que, por vezes, colocamo-nos. Elas nos instigam a estabelecer relações e a deambular, fazendo com que a agitação tácita da imagem tenha a potência de ressoar, alastrando-se ao infinito.

As imagens silenciosas podem ser potentes para disparar o pensar, pois oferecem o silêncio necessário para que possamos nos ouvir. É nesse sentido que, no silêncio impactante do final do filme, um hiato se faz presente e isto parece nos inquietar. Por oferecer tantos pontos de interrogação e apresentar um final incerto, sem respostas a tantos 'porquês' lançados durante o filme, sem um 'fechamento', sem um 'ponto final', isso causa incômodo e nos tira dos eixos.

Paradoxalmente, são essas mesmas sensações de desconforto que também nos capturam e nos fazem pensar na experiência educativa, movendo-nos a problematizar algumas questões: por que este sentimento em que tudo necessita ter um encerramento? Por que precisamos chegar a conclusões semelhantes e entender a mesma coisa? Por que precisamos deixar tudo tão amarrado, sem espaços para outros finais, ou melhor, outros 'meios' e outras possibilidades? Por que na experiência educativa necessitamos tudo explicar e arrematar? Por que precisamos fazer o 'fechamento' de nossas aulas, como se elas necessitassem de uma conclusão? Não poderíamos deixar ecoando problemas, em vez de encerrar com respostas?

A experiência com o filme nos oferece, ao final, uma lacuna não preenchida, uma impressão de algo não terminado, deixando uma abertura e uma expectativa de algo por vir. É uma sensação de algo mais, de reticências, instigando-nos a pensar nesta outra possibilidade de temporalidade, como algo intenso e que dura. 
A duração aparenta estar naquilo que uma imagem-tempo faz brotar em nós e no desassossego a que ela nos lança.

\section{ATRAVESSAMENTOS QUE NOS INSTIGAM A PROBLEMATIZAR A RELAÇÃO COM A IMAGEM FÍLMICA}

No território de confluência do filme investigado, buscamos, neste texto, apostar na problematização e no estabelecimento de relações com os conceitos de imagem-movimento e de imagem-tempo. Nossa intenção não foi fazer um comparativo excludente entre os dois tipos de imagens, colocando que uma tem mais importância que a outra, mas de mostrar o quanto elas operam nos filmes, quais suas implicações e de que forma instigam a nossa maneira de pensar.

Dessa forma, intentamos com as imagens-tempo do filme A Árvore da Vida (2011) incitar o pensamento, pois é no interstício, no 'entre' dessas imagens que muitas coisas podem ser cruzadas e construídas. Nesse espaço aberto das imagens, as alianças são concebidas e inesperadas construções de sentido são invencionadas, fazendo-nos compreender que a maneira de nos relacionar com a imagem não depende somente do olhar do observador, tampouco do que é visualizado, e sim daquilo que é possível de ser produzido.

Ao trabalhar e explorar o filme, foi possível incitar a reflexão acerca de possíveis desdobramentos que não se parecessem com o mesmo, que não fossem substituídos pela metáfora, que não desencadeassem movimentos semelhantes, caindo em um prolongamento do que já existe. O desafio foi pensar em possibilidades provisórias e substituíveis, sempre em devir.

Investir na relação com a imagem, sem a preocupação em corresponder, equivaler, interpretar e reproduzir, passa a ser um esforço diário, pois como Deleuze (1990) explica:

nós não percebemos a coisa ou a imagem inteira, percebemos sempre menos, percebemos apenas o que estamos interessados em perceber, ou melhor, o que temos interesse em perceber, devido a nossos interesses econômicos, nossas crenças ideológicas, nossas exigências psicológicas. Portanto, comumente, percebemos apenas clichês (DELEUZE, 1990, p. 31). 
A comodidade dos lugares-comuns faz com que venhamos a repetir o que é previsível, o que é corriqueiro e trivial. Converter as disposições sensório-motoras em disposições óticas e sonoras puras requer a criação de maneiras diferenciadas de entendimento, trazendo para o debate as imagens chavões que nos fazem repetir o mesmo e as metáforas que fazem resultar imagens concordantes com o que já existe.

Talvez a provocação maior esteja em problematizar essas imagens que nos são familiares e nos dão segurança, buscando trazer para a discussão uma nova imagem do pensamento, ou melhor, um pensamento sem imagem. "Um pensamento sem imagem é aquele que não obedece a uma imagem prévia do que seja pensar, isto é, a um modelo prévio que orienta e formata, que determinaria de antemão o que significa pensar" (PELBART, 2010, p. 28-29).

Ao se deixar violentar pelos signos que o diálogo entre a imagem fílmica selecionada, os conceitos investigados e a experiência educativa provocam, oportunizamos diferentes relações e um alastramento de possibilidades em circuitos cada vez mais amplos. As ressonâncias que foram dissipadas podem ser vistas "como aventuras singulares do pensamento às quais a existência múltipla do cinema deu vida" (RANCIĖRE, 2012, p. 17) e têm a propriedade de se renovar a cada novo encontro, pois as relações e as problematizações suscitadas em relação à imagem fílmica são inexauríveis.

Ao pensarmos de maneira especial na experiência educativa, poderíamos afirmar que o desafio está em se deixar despojar de imagens fílmicas que assegurem um cenário conhecido, um roteiro fixo, um personagem que represente sempre o mesmo papel e se encaminhe para um final previsível. A coragem está em vislumbrar diferentes cenários e roteiros, mudar os scripts, conforme as contingências de cada cena, oferecer espaços para a improvisação e ficcionar tantos finais quantos forem possíveis.

\section{O QUE APRENDEMOS COM ESSA EXPERIÊNCIA? ALGUMAS POSSIBILIDADES...}

Procuro despir-me do que aprendi,

Procuro esquecer-me do modo de lembrar que me ensinaram, E raspar a 
tinta com que me pintaram os sentidos (...)

E assim escrevo, querendo sentir a Natureza, nem sequer como um homem,

Mas como quem sente a Natureza, e mais nada (PESSOA, 2006, p. 25).

Os dois encontros que tivemos com o filme A Árvore da Vida (2011), tanto a experiência no cinema quanto na universidade com os acadêmicos, mostraram-nos que as sensações de incômodo e de dissonância preponderaram. Alguns não se sentiram nem um pouco afetados pelas imagens, negando-se a entrar em contato por não fazerem sentido para eles. Outros foram tocados de um modo singular e conseguiram estabelecer conexões para além do que parecia esperado.

Na experiência educativa não acontece o mesmo? Lançamos convites, possibilidades de encontros, aproximações com signos, mas não temos certeza de que esse endereçamento chegará a seu destinatário, que o convite será aceito e que as relações irão acontecer. O pensar pode ou não acontecer, visto que depende das contingências de um encontro, das forças implicadas, do quanto nos deixamos violentar pelo impensado do pensamento.

É essa incerteza que nos impulsiona a seguir adiante na docência, é esse espaço desconhecido e desafiador que nos incita a apostar na educação. Gallo (2003) sugere que é justamente aí que se reconhece "a beleza do processo educativo: agimos, sem nunca saber qual será o resultado de nossas ações" (GALLO, 2003, p. 103). É quando percorremos um espaço não familiar que nos sentimos vivos, atuantes, pois não estamos apenas representando as cenas que ensaiamos e reproduzindo as falas que decoramos, mas estamos vivendo intensamente cada encontro.

Deixar-se contaminar pelas imagens inusitadas do percurso, pelas sensações que nos são oferecidas, pelo que acontece no 'entre' do mundo, possibilita viver a cada dia de maneira renovada. Talvez essa seja uma oportunidade de 'desaprender' o que já se sabe, de desapegar de verdades fixas e limitadoras e se abrir ao que não se sabe, a algo que não está previsto. Essa abertura oportuniza a possibilidade das certezas se modificarem e nascerem diferentes do que eram, viabilizando que inusitados saberes possam vir ao mundo e que as experiências se diferenciem a cada vez. 
Portar um olhar livre, desapegado e sem o compromisso de sempre reconhecer e interpretar talvez seja o nosso desafio maior. E, quiçá, com tudo isso, possamos visualizar aquilo que não era visto ou, quem sabe, ver de outro modo o que era visualizado costumeiramente, instigando-nos a nos 'despir do que aprendemos', para, a partir disso, sermos capazes de inventar outras possibilidades de 'pintar' no mundo.

\section{REFERÊNCIAS}

A ÁRVORE da Vida. Direção: Terrence Frederick Malick. Estados Unidos, 2011. Disponível em: <https://www.youtube.com/watch?v=ITHQcWt5Tq0>. Acesso em: 28 jul., 2015.

BLANCHOT, Maurice. A parte do fogo. Tradução: Ana Maria Scherer. Rio de Janeiro: Rocco, 1997.

GALLO, Silvio. Deleuze \& a Educação. Belo Horizonte: Autêntica, 2003.

GILLES, Deleuze. Cinema 1 - A imagem-movimento. Tradução: Stella Senra. São Paulo: Brasiliense, 1983.

GILLES, Deleuze. Cinema 2 - A imagem-tempo. Tradução: Eloisa de Araújo Ribeiro. São Paulo: Brasiliense, 1990.

GILLES, Deleuze. Proust e os Signos. Tradução: Antônio Piquet e Roberto Machado. 2. ed. Rio de Janeiro: Forense Universitária, 2006a.

GILLES, Deleuze. Diferença e repetição. Tradução: Luiz Orlandi e Roberto Machado. 2. ed. Rio de Janeiro, 2006b.

GILLES, Deleuze. A dobra: Leibniz e o barroco. Tradução: Luiz Orlandi. 4. ed. Campinas, SP: Papirus, 2007.

GILLES, Deleuze. Conversações. Tradução: Peter Pál Pelbart. 2. ed. São Paulo: Ed. 34, 2010.

PELBART, Peter Pál. O tempo não reconciliado. Imagens de tempo em Deleuze. São Paulo: Perspectiva, 2010. 
PESSOA, Fernando. Obra poética II - poemas de Alberto Caeiro. Porto Alegre: L\&PM, 2006.

RANCIĖRE, Jacques. As distâncias do cinema. Tradução: Estela dos Santos Abreu. Rio de Janeiro: Contraponto, 2012.

OLIVEIRA, Marilda Oliveira de. O cinema como modo de pensamento, o cinema como forma de forçar a pensar. In: MARTINS, Raimundo; TOURINHO, Irene (orgs.) Pedagogias culturais. Santa Maria, Edufsm, 2014. p. 165-176.

VASCONCELLOS, Jorge. Deleuze e o Cinema. Rio de Janeiro: Editora Moderna Ltda, 2006.

ZABALZA, Miguel. Diários de aula: um instrumento de pesquisa e desenvolvimento profissional. Tradução: Ernani Rosa. Porto Alegre: Armed, 2004. 


\section{SOBRE OS ORGANIZADORES}

\section{ANA CLÁUDIA BARIN}

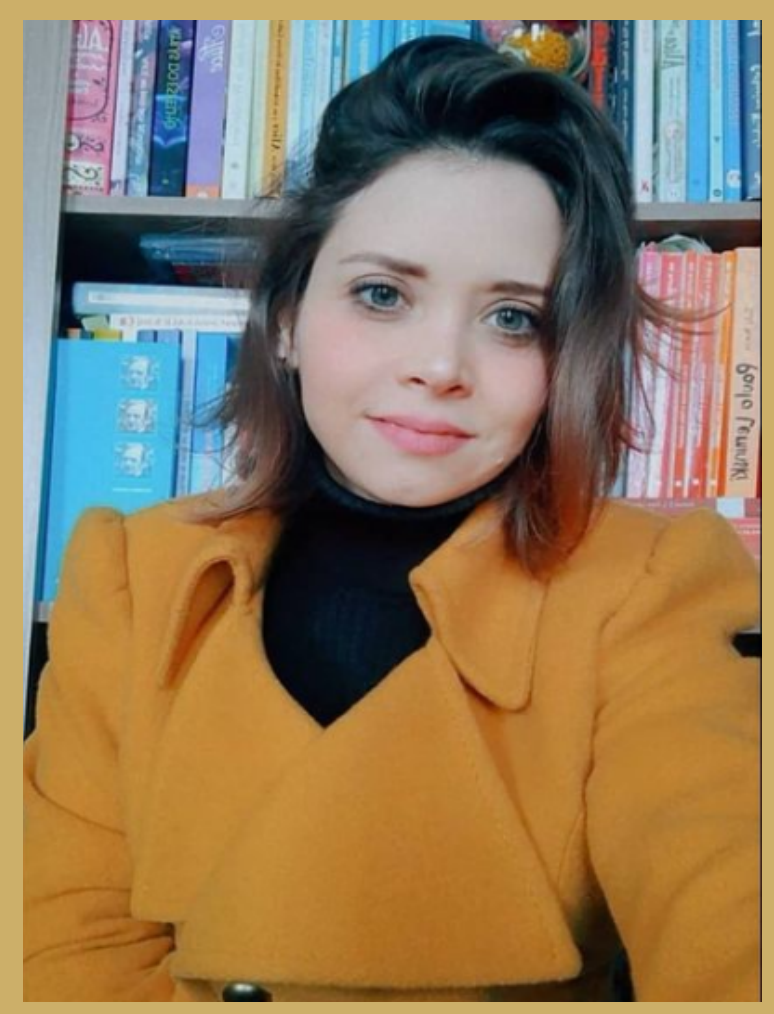

Doutora (2019) e Mestra em Educação pelo Programa de Pós-Graduação em Educação(PPGE), na linha de Pesquisa Educação e Artes - LP4, ambos pela Universidade Federal de Santa Maria (UFSM). Possui Especialização em Metodologias do Ensino das Artes (2018) pelo Centro Universitário Internacional (UNINTER), PR. Bacharel (2010) e Licenciada (2013) em Artes Visuais pela Universidade Federal de Santa Maria (UFSM) e acadêmica do curso de Pedagogia (2021 - atual) pela mesma instituição (UFSM). Desenvolve pesquisa em arte, educação, infâncias e fabulação. Professora pesquisadora do GEPAEC: Grupo de Estudos e Pesquisas em Arte, Educação e Cultura, e do Grupo de Estudos e Pesquisas em Educação - FIANDAR, diretório CNPq. 


\section{ANGÉLICA NEUSCHARANK}

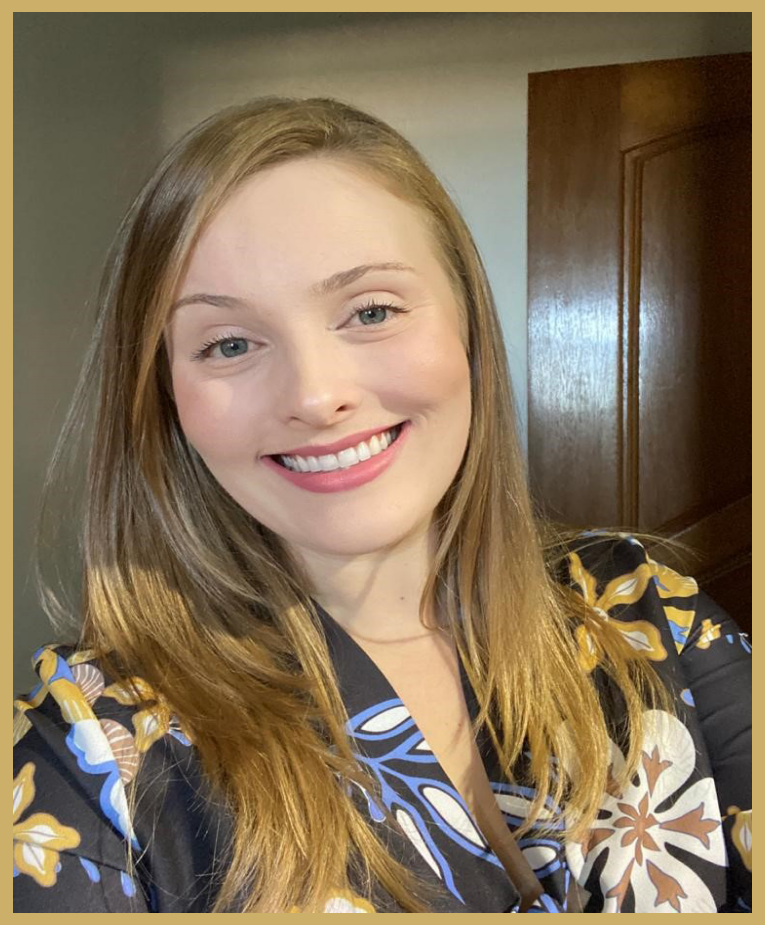

Doutora (2019) e Mestra (2015) em Educação pelo Programa de Pós-Graduação em Educação (PPGE), na linha de Pesquisa Educação e Artes - LP4, ambos pela Universidade Federal de Santa Maria (UFSM). Possui Especialização em Tecnologias da Informação e da Comunicação Aplicadas à Educação (2014), pela mesma instituição e Especialização em Práticas Assertivas em Didática e Gestão da Educação Profissional integrada à EJA (2020) pelo Instituto Federal do Rio Grande do Norte (IFRN). Graduada em Artes Visuais - Licenciatura Plena em Desenho e Plástica (2011), pela UFSM e graduanda em Pedagogia (2020 - atual ), pela Uninter. Vem desenvolvendo estudos em arte, educação, docência e filosofias da diferença. Professora pesquisadora do GEPAEC: Grupo de Estudos e Pesquisas em Arte, Educação e Cultura, e do Grupo de Estudos e Pesquisas em Educação - FIANDAR, diretório CNPq. 


\section{FABIANO ELOY ATÍLIO BATISTA}

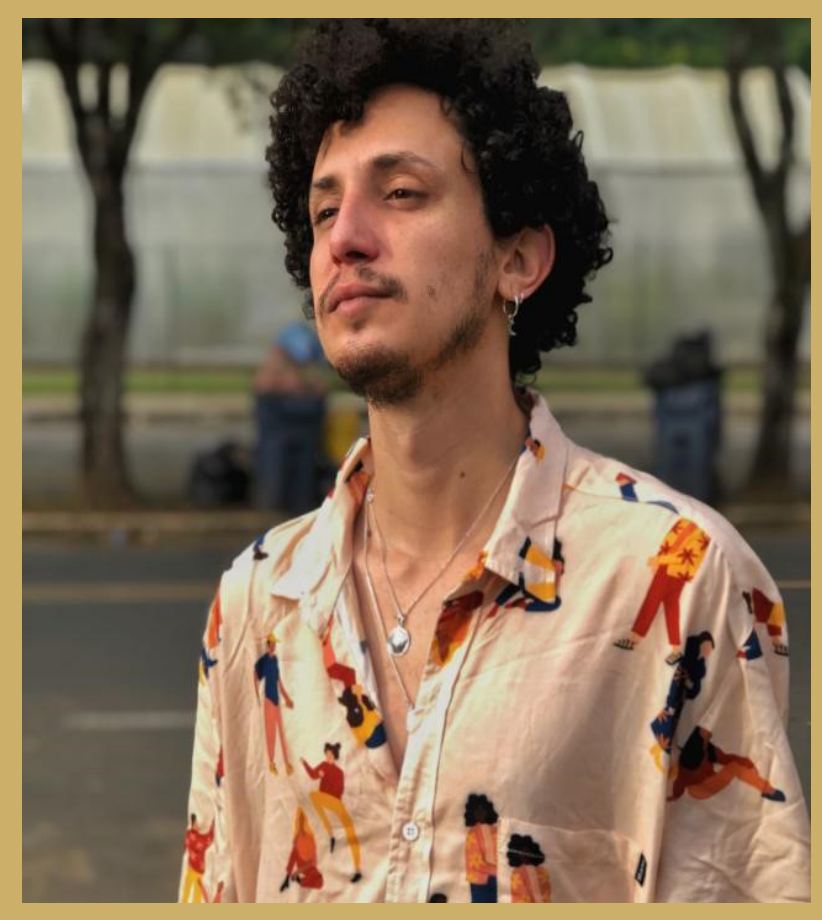

Doutorando e Mestre pelo Programa de Pós-Graduação em Economia Doméstica (PPGED) - área de concentração em Família e Sociedade - pela Universidade Federal de Viçosa (UFV), atuando na linha de pesquisa Trabalho, Consumo e Cultura. Possui graduação em Tecnologia em Design de Moda, pela Faculdade Estácio de Sá - Juiz de Fora/MG; Bacharelado Interdisciplinar em Ciências Humanas, pelo Instituto de Ciências Humanas da Universidade Federal de Juiz de Fora (BACH/ICH - UFJF), e Licenciatura em Artes Visuais, pelo Centro Universitário Internacional (UNINTER). Especialização em Moda, Cultura de Moda e Arte, pelo Instituto de Artes e Design da Faculdade Federal de Juiz de Fora (IAD/UFJF). Especialização em Televisão, Cinema e Mídias Digitais, pela Faculdade de Comunicação da Universidade Federal de Juiz de Fora (FACOM/UFJF). Especialização em Docência na Educação Profissional e Tecnológica, pelo Instituto Federal de Educação, Ciência e Tecnologia do Sudeste de Minas Gerais - Campus Rio Pomba (IF Rio Pomba). Especialização em Ensino de Artes Visuais, pela Faculdade de Educação da Universidade Federal de Juiz de Fora (FACED/UFJF). 
www.arcoeditores.com

ISBN: 978-65-89949-09-1

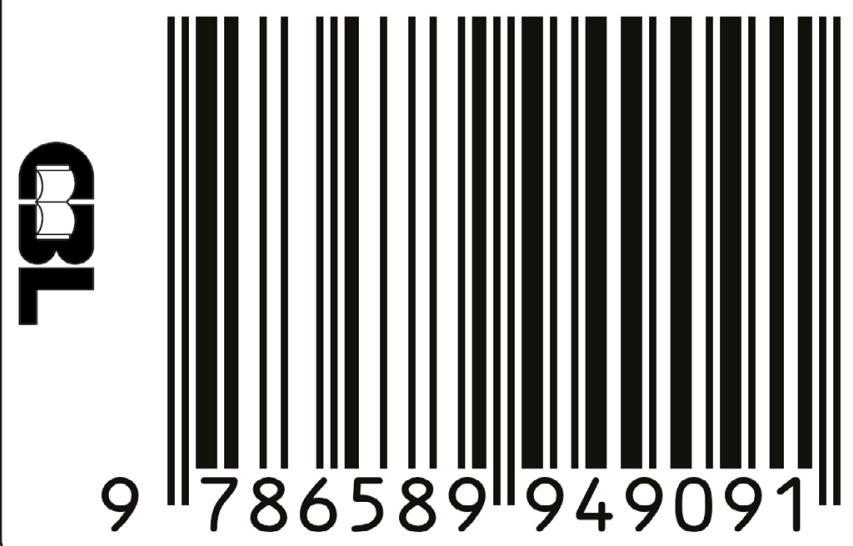

